\title{
Thesis Memory
}

\section{Novel Thermally Rearranged Copolymers and Application for Gas Separation Membranes}

\author{
Hye Jin Jo
}

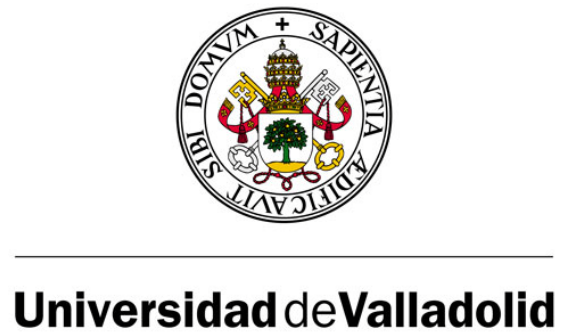

Dissertation submitted to the Universidad of Valladolid at Valladolid, Spain, in Fulfilment of the Requirements for the Award of the Degree of Doctor of Philosophy

Universidad of Valladolid

October, 2015
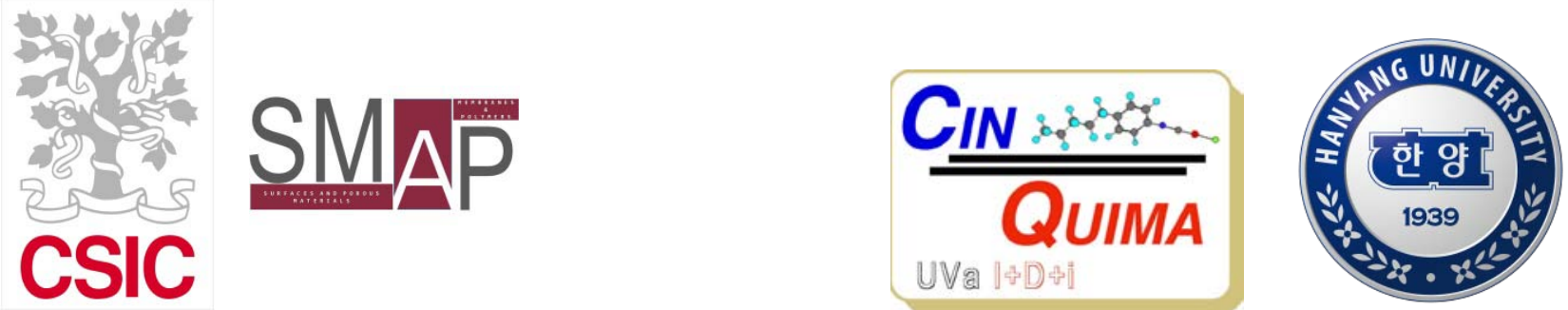


\title{
Ph D Advisors:
}

\author{
Dr. Angel E Lozano (Ph D Advisor) \\ Senior Researcher of Institute of Polymer Science and \\ Technology, CSIC, Madrid, Spain
}

Researcher of SMAP, University of Valladolid-CSIC research unit, Valladolid, Spain

\section{Dr. Young Moo Lee (Ph D Advisor)}

Professor of Energy Engineering, Hanyang University, Seoul, Republic of Korea 


\section{Acknowledgments}

Hye Jin Jo should acknowledge Department of Energy of Hanyang University for the help and financial support provided in the carrying out of this work. Also, Institute of Polymer Science and Technology (ICTPCSIC) is kindly acknowledged. Moreover, the help provided by SMAP (Research Unit between the Department of Applied Physic of the University of Valladolid and the Department of Applied Macromolecular Chemistry at ICTP-CSDIC) is widely recognized. Finally, help provided by the University Unit CINQUIMA from the University of Valladolid should be mentioned.

This research was mainly supported by the Korea Carbon Capture \& Sequestration R\&D Center (KCRC) through the National Research Foundation of Korea (NRF) funded by the Ministry of Science, ICT, and Future Planning (NRF-2014M1A8A1049305). The financial support also was provided by the Spanish MINECO (MAT2011-25513, MAT2010-20668, and MAT2013-45071-R) and for specific projects between Hanyang University and ICTP-CSIC. 


\section{Sumario en Español}

\section{Introducción}

Existe una tendencia innata de la familia humana de aumentar su bienestar. Además, existe una necesidad ética de que ese bienestar se dé en todos los lugares del mundo. No obstante, y aunque las mejoras conseguidas desde el inicio de la revolución industrial hasta nuestros días ha permitido que en muchos lugares de los denominados países del primer mundo, la tasa de bienestar, amplificada por la alta tecnología desarrollada en el Siglo XX, sea muy satisfactoria. No obstante, ese desarrollo industrial ha traído consigo una serie de problemas de difícil solución, y que exigen una respuesta y solución a muy corto plazo. Entre ellos, y sin entrar en aspectos más filosóficos, se podrían mencionar:

1. Disminución de la tasa de gases de efecto invernadero en la atmósfera, con objeto de disminuir el efecto invernadero

2. Disminución del consumo energético, lo que disminuiría el uso de combustibles fósiles, y aumento de las energías alternativas como la energía solar y la energía eólica.

Uno de los avances tecnológicos más importantes del final del siglo XX ha sido el desarrollo industrial de los procesos de separación por membranas como son la ultrafiltración, la diálisis, la ósmosis inversa, la pervaporación o la permeación selectiva de gases industriales

Aunque estos avances han ido asociados al descubrimiento de nuevos materiales de diversos tipos: cerámicos, metálicos, poliméricos; hasta el momento, solo los polímeros han permitido resolver favorablemente las relaciones prestaciones-preciodurabilidad que han de cumplirse en cualquier desarrollo industrial.

En este contexto se inscribe esta memoria, que está dirigido al diseño y preparación de nuevas membranas poliméricas para ser evaluadas como materiales alternativos en procesos de separación de gases, y donde se han aplicado los últimos conocimientos en este tema para poder obtener materiales con mejores propiedades y donde se eliminen algunos de los inconvenientes de la actual generación de membranas de alta eficiencia. En particular, la separación de gases se ha dirigido a la separación de mezclas de gases donde uno de sus componentes sea el dióxido de carbono. 
La separación de gases mediante membranas selectivas es una operación relativamente poco desarrollada que ha encontrado utilidad en casos concretos, pero no ha conseguido desplazar todavía a los procesos tradicionales como son la separación mediante absorbentes específicos o la destilación criogénica. No obstante, se han producido ya algunos desarrollos de interés industrial (puede señalarse que el $30 \%$ del nitrógeno industrial se produce ya por separación de los componentes del aire mediante membranas poliméricas semipermeables) y se cuenta además con el conocimiento necesario para la explotación de las membranas, gracias al gran esfuerzo innovador realizado por muchos grupos en todo el mundo.

Para caracterizar completamente una película de polímero como membrana de separación de gases, es necesario definir sus parámetros de transporte, que son el Coeficiente de Difusión o Difusividad (D), el Coeficiente de Solubilidad (S) y la Permeabilidad (P).

La Permeabilidad de un gas $\mathrm{A}$ a través de una membrana $\left(\mathrm{P}_{\mathrm{A}}\right)$ se define como el volumen de gas que pasa a través de un espesor 1 de membrana por unidades de tiempo, presión y área de membrana. Matemáticamente:

$$
P_{A}=\frac{N_{A} \cdot l}{\left(p_{2}-p_{1}\right)}
$$

donde $\mathrm{N}_{\mathrm{A}}$ es el flujo de gas a través de la membrana, $\mathrm{p}_{2}$ es la presión de alimentación y $\mathrm{p}_{1}$ es la presión del permeado. Cuando el valor de $\mathrm{p}_{1}$ es suficientemente pequeño $\left(\mathrm{p}_{2}>>\mathrm{p}_{1}\right)$, es posible hacer una serie de aproximaciones, llegando a la siguiente expresión:

donde $\mathrm{D}_{\mathrm{A}}$ (Coeficiente de Difusión) da idea de la movilidad de las moléculas de gas que penetran en la membrana, expresado en $\mathrm{cm}^{2} / \mathrm{s}$, y $\mathrm{S}_{\mathrm{A}}$ (Coeficiente de Solubilidad) representa la cantidad de gas que puede quedar retenido en la membrana (expresado como concentración de gas absorbido por unidad de volumen de membrana) una vez alcanzado el equilibrio con la presión de gas suministrada a la membrana. El primero es un parámetro cinético que depende principalmente de la movilidad del permeante, los movimientos de cadena y el volumen libre del polímero. El segundo es un parámetro termodinámico que esta condicionado por las interacciones gas/polímero.

$$
P_{A}=D_{A} \cdot S_{A}
$$


Para una mezcla de dos gases i,j, la Selectividad o Factor de Separación del componente $\mathrm{i}$ frente al componente $\mathrm{j}$ se define como el cociente de las permeabilidades de ambos gases:

$$
\alpha_{i, j}=\frac{P_{i}}{P_{j}}=\frac{D_{i}}{D_{j}} \cdot \frac{S_{i}}{S_{j}}
$$

Aunque existen muchos tipos de polímeros, y aparecen nuevas estructuras continuamente, muy pocos ofrecen un balance de propiedades adecuado para ser candidatos en el campo de la separación de gases. Si consideramos las condiciones de innovación y potencial competitividad exigibles, solo pueden considerarse los polímeros que cumplan con los siguientes requisitos mínimos:

- Capacidad de procesado a filmes y membranas, preferiblemente a partir de disoluciones

- Baja o nula cristalinidad

- Temperatura de transición vítrea al menos $100{ }^{\circ} \mathrm{C}$ superior a la ambiente

- Estabilidad térmica por encima de $300{ }^{\circ} \mathrm{C}$ (TGA, aire)

- Buenas propiedades mecánicas (Carga a rotura $>60 \mathrm{MPa}$, Módulo $>2 \mathrm{GPa}$ )

- Buena resistencia química

- Bajo envejecimiento físico, entendiendo éste como una pérdida de la fracción de volumen libre del material a lo largo del tiempo.

Salvo escasísimas excepciones, únicamente algunos polímeros de condensación aromáticos son capaces de satisfacer estas condiciones.

Además, los materiales obtenidos han de reunir unas propiedades como membranas que los hagan competitivos frente a otras tecnologías o que permitan su uso en nuevas aplicaciones que están emergiendo debido a requisitos medio-ambientales o sociales. Por ejemplo, para la pareja oxígeno/nitrógeno la idea es alcanzar permeabilidades al oxígeno superiores a 50 Barrers (1 Barrer $\left.=10^{-10} \mathrm{~cm}^{3}(\mathrm{STP}) \cdot \mathrm{cm} / \mathrm{cm}^{2} \cdot \mathrm{s} \cdot \mathrm{cmHg}\right)$ y selectividades oxígeno/nitrógeno superiores a 8 , y para la pareja dióxido de carbono/metano, permeabilidades al dióxido de carbono superiores a 100-200 Barrers, con selectividades dióxido de carbono/metano superiores a 40. Estas condiciones de 
separación están al alcance de muy pocos polímeros, incluso dentro del campo de los polímeros especiales que acabamos de comentar. En la actualidad, existe una búsqueda de nuevos materiales capaces de separar parejas de gases que hace tiempo no se contemplaban como de importancia económica. Entre estas nuevas aplicaciones, algunas de ellas derivadas del problema del calentamiento global o del aprovechamiento de recursos naturales que no se han obtenido usando tecnologías avanzadas (p.ej. pozos que poseen cantidades importantes de petróleo o de gas donde se utilizaron métodos anticuados de extracción, aprovechamiento del carbón en centrales térmicas más eficientes o para la producción de gas de síntesis, etc.) destacan la separación inversa de oxígeno/nitrógeno, separación de metano de nitrógeno, separación de gases ácidos que poseen azufre, y un largo número de aplicaciones que en la actualidad tienen un nicho de actuación económica muy importante.

Es por ello del máximo interés el desarrollo de nuevos polímeros, que ofrezcan unas características sustentadas por una composición química más adecuada, capaces de conducir a membranas con mejores propiedades. Esto exige una gran capacidad para la síntesis de nuevas estructuras, diseñadas en función de la propia experiencia y del conocimiento al que se tiene acceso, que permitan mejorar los materiales que se usan en la actualidad.

El mecanismo de actuación de las membranas para gases está basado principalmente en la separación por difusión, actuando las membranas como tamices a nivel molecular, que permiten el paso de los gases a través del volumen libre del sistema (volumen no ocupado por las cadenas de polímero dentro del material). Según este mecanismo, la movilidad de las moléculas de gas se produce gracias a pequeñas reorganizaciones de la cadena polimérica, y por tanto del volumen libre, que permiten el salto de la molécula de gas desde un microhueco a otro. Por ello, el principal factor que controla la separación es la diferencia de tamaño entre los diversos gases, aunque existen también otros factores importantes, principalmente la solubilidad, parámetro termodinámico controlado por las interacciones entre las moléculas de los gases y las moléculas de polímero. En la siguiente figura se exponen los diversos mecanismos aceptados para la difusión de gases en materiales. 

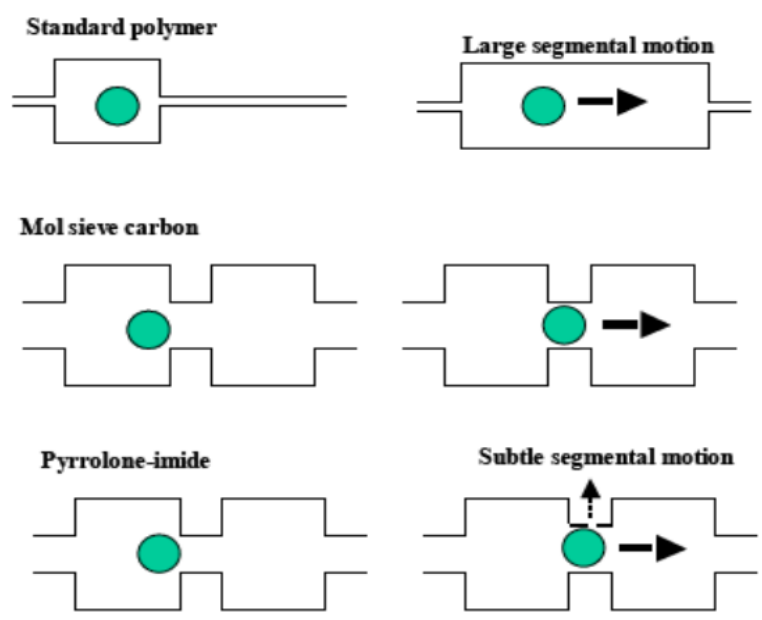
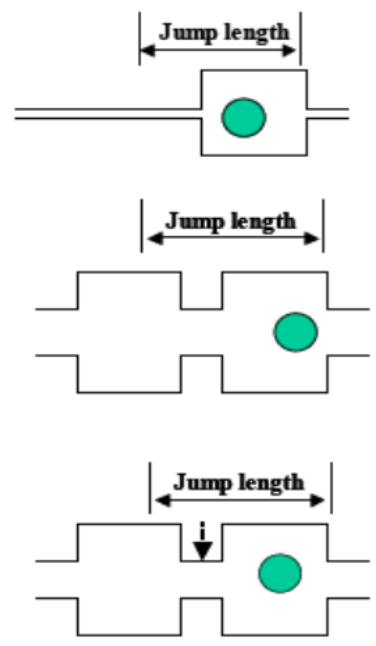

Figura 1. Ilustración idealizada de la difusión mediante saltos entre unidades de volumen libre del gas penetrante en membranas poliméricas clásicas (arriba), en tamices moleculares de carbono, CMS, (medio) y en polímeros de naturaleza ultra-rígida (abajo)

Una membrana óptima para procesos de separación es aquella que posee a la vez elevados valores de permeabilidad y selectividad. Como consecuencia de este mecanismo, existe una relación inversa entre la permeabilidad de una membrana frente a diferentes gases y su capacidad para separar estos gases (selectividad). Esta relación, prácticamente universal, es el principal inconveniente que presentan las membranas frente a otros procesos de purificación de gases, puesto que cuando se consigue un aumento de permeabilidad, se produce simultáneamente una disminución de selectividad y viceversa. Evaluando una gran cantidad de parejas de datos permeabilidad/selectividad experimentales, Robeson propuso una relación empírica conocida como condición límite de Robeson, que representa el valor límite de selectividad que puede dar una membrana polimérica con una permeabilidad dada. Hasta la fecha, los polímeros que más se aproximan a dicho límite (y en algunos casos lo llegan a superar) son algunas politriazinas y polipirrolonas, y últimamente los denominados polímeros de microporosidad intrínseca, PIMs, materiales que son muy difíciles de procesar debido a su bajísima solubilidad en disolventes orgánicos convencionales o su problemática a la hora de sus síntesis y los polímeros obtenidos por reordenamiento térmico (materiales TR). Los últimos dos juegos de polímeros representan ahora mismo la investigación más fructífera y prometedora en el campo de la separación de gases. Más tarde en 2008, el propio Robeson hizo una revisión de su trabajo de 1991, y generó unos nuevos límites de compromiso entre selectividad y 
permeabilidad

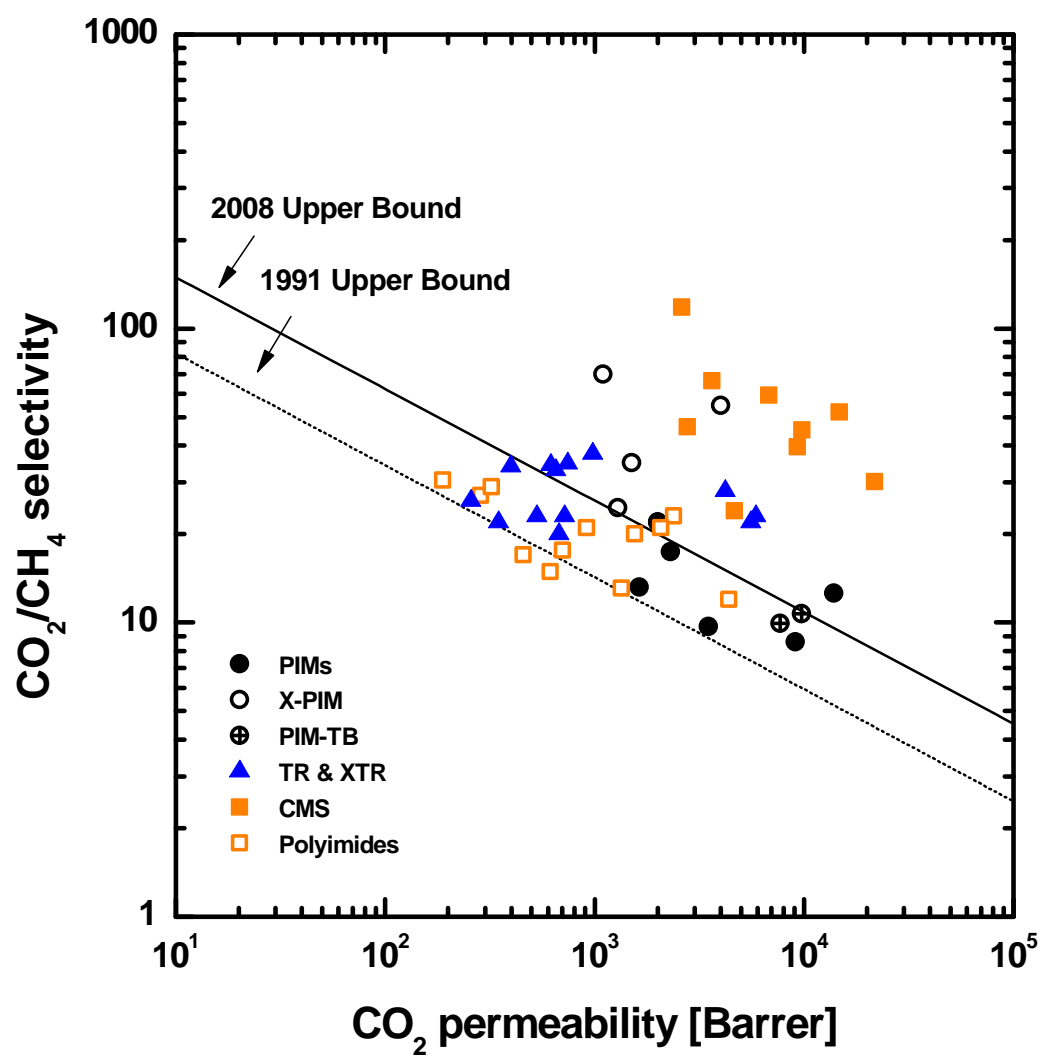

Figura 2. Gráfica de permeabilidad (eje $X$ ) frente a selectividad (eje $Y$ ) de una amplía variedad de materiales polímeros para la pareja de gases $\mathrm{O}_{2} / \mathrm{N}_{2}$. En la gráfica se ha representado el límite superior de Robeson (upper bound).

Además, el conocimiento adquirido durante los últimos años en este campo ha permitido establecer algunas reglas básicas para conseguir que los aumentos de una de estas dos características de las membranas (permeabilidad o selectividad) conduzcan a una disminución lo más pequeña posible en la otra. Se ha encontrado que los mejores materiales para estas membranas están basados en polímeros amorfos, con estructuras que dificulten el empaquetamiento, lo que da lugar a una elevada fracción de volumen libre y por ello a mucha permeabilidad, pero que al mismo tiempo posean una importante rigidez, lo que disminuirá la movilidad de las cadenas y facilitará el comportamiento como tamices moleculares, dando lugar a una elevada selectividad. Dentro de este ámbito, las poliimidas aromáticas, cuya estructura se esquematiza en la Figura 3 se han revelado como algunos de los mejores polímeros, debido a su altísima rigidez, sus excelentes propiedades térmicas y 
mecánicas y la posibilidad de obtener estructuras a medida, mediante la introducción de diferentes grupos modificadores. En particular, las poliimidas con grupos laterales voluminosos han dado lugar a membranas con excelentes propiedades.

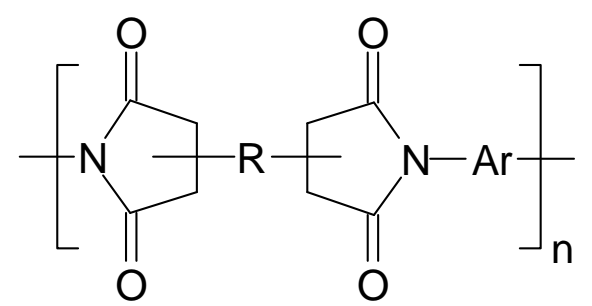

Figura 3. Esquema de la estructura de una poliimida aromática

No obstante, algunos de los principales inconvenientes que ha encontrado la investigación en este campo provienen de la forma de definir y caracterizar el volumen libre y la rigidez. Así, normalmente se ha recurrido a los métodos de ensayo y error, sintetizando nuevas estructuras a ojo y determinando sus propiedades de membrana, para modificar estas estructuras en función de los resultados obtenidos.

Es necesario, por tanto, un método más elaborado, que permita la selección de los polímeros en función de su estructura a nivel micro y mesoscópico, haciendo posible la determinación de los parámetros que controlan tanto la fracción de volumen libre como la rigidez de cadena.

La determinación de la fracción de volumen libre se lleva a cabo habitualmente a partir de la medida experimental del volumen específico y del cálculo del volumen de van der Waals (volumen ocupado exclusivamente por la molécula) por diferentes métodos. Aunque este método es bastante fiable, tiene dos inconvenientes fundamentales: a) exige la síntesis del polímero para determinar su densidad experimental, b) permite determinar la fracción global de volumen libre, FFV, pero no permite conocer como es la distribución del volumen libre en el material (el comportamiento de una membrana será muy diferente en función de que existan pocos huecos grandes o muchos huecos pequeños). Otras técnicas más precisas en la determinación de la FFV y su distribución (aniquilación positrónica (PALS), RMN${ }^{129} \mathrm{Xe}$, etc), son muy complejas, exige una elevada especialización del grupo que las realiza, y su análisis es difícil de procesar. Entre ellas, la técnica PALS está aceptada como la herramienta que da una mejor estimación del volumen libre debido al pequeño tamaño de la sonda utilizada, además de la fracción de volumen libre, FFV, está técnica 
da cuenta de la distribución del volumen libre. No obstante, la técnica posee limitaciones derivadas del elevado tamaño del material a medir debido a la elevada intensidad de la fuente de positrones (en general, la fuente de positrones procede de una pequeña cantidad de material radiactivo, ${ }^{22} \mathrm{Na}$ ). Por ello, se suele utilizar un apilamiento de membranas hasta conseguir un espesor de 0,5 a $1 \mathrm{~mm}$. Este apilamiento conduce a errores en la medida y ha limitado el uso de la técnica en nanociencias o en el campo de las membranas de separación. No obstante, en los últimos tiempos han aparecido nuevos sistemas donde la energía del flujo de positrones que incide sobre la muestra se ha disminuido (low-energy beam PALS), lo que permite el uso de la técnica en sistemas nanoscópicos con espesores muy inferiores a la micra). Esta técnica posee el inconveniente de que pocos grupos tienen acceso a ella.

Otro aspecto a considerar y que se está explorando activamente en la actualidad es la idea de considerar la fracción de volumen libre accesible (eficaz distribución de volumen libre) como el factor determinante en los procesos de separación de gases. La idea es obvia ya que muchas unidades de FFV son tan pequeñas que ciertos gases no se pueden alojar en ellas, para iniciar el proceso de salto de ellas a otras unidades de FFV.

Por lo que respecta a la movilidad de las cadenas, se han postulado diferentes parámetros para determinarla. El más utilizado es la temperatura de transición vítrea (Tg), que también plantea el inconveniente de que es necesario obtener el polímero para determinarla experimentalmente. Además, resultados preliminares obtenidos en nuestro grupo han mostrado que este parámetro, que determina la movilidad de fragmentos de cadena relativamente grandes, no es capaz de predecir la movilidad de fragmentos más pequeños, o de sustituyentes laterales de la estructura, que normalmente es suficiente para que se produzcan reorganizaciones en la distribución del volumen libre, que permitan el salto de la molécula de gas de un hueco a otro. Por ello, para una adecuada caracterización de la movilidad es necesario determinar, además de la $\mathrm{Tg}$, las relajaciones que se producen a temperaturas inferiores a la $\operatorname{Tg}$ (relajaciones $\beta$ y $\gamma$ ) e intentar correlacionarlas con los parámetros de permeabilidad y selectividad de la membrana. Esas transiciones se ven afectadas en algunos casos por la presencia de ciertas moléculas en el medio $\left(\mathrm{H}_{2} \mathrm{O}\right.$ o gases que posean momentos dipolares, cuadrupolares o capacidad de formar enlaces de hidrógeno, como $\mathrm{CO}_{2}, \mathrm{SO}_{2}, \mathrm{SH}_{2}$ ). $\mathrm{La}$ presencia de estos gases afectará a las propiedades de las membranas y por ello, una de las ideas que se proponen en este trabajo es realizar determinaciones de las propiedades mecano-dinámicas y dieléctricas de los polímeros plastificados con esos gases. 


\section{Objetivos}

A la vista de lo expuesto, se resumen a continuación los objetivos que se han pretendido alcanzar en este proyecto de tesis;

1) Obtención de nuevos resultados en el campo de la preparación de polímeros de especiales prestaciones. Puesta a punto de nuevos métodos de síntesis de monómeros y polímeros.

2) Preparación de nuevas familias de polímeros de altas prestaciones con aplicación en membranas semipermeables para separación de gases. Estos polímeros han consistido esencialmente en el desarrollo de poliímidas con grupos hidroxilo situados en la posición orto- respecto al nitrógeno amínico. Estas poliimidas han sido tratadas térmicamente a elevadas temperaturas, superiores a $\operatorname{los} 350{ }^{\circ} \mathrm{C}$, para obtener polibenzoxazoles que poseen elevadas fracciones de volumen libre.

3) Obtención de nuevas membranas con propiedades que superen ampliamente a las mejores membranas comerciales, con especial énfasis en la separación de los siguientes gases; $\mathrm{CO}_{2}$ y $\mathrm{CH}_{4}$.

4) Análisis de los resultados obtenidos en los puntos anteriores para encontrar relaciones estructura-propiedades, en especial las relaciones composición químicapropiedades de permeación de gases. Este punto es fundamental para obtener polímeros que poseen una combinación de permeabilidad y selectividad muy superior a la presentada por polímeros comerciales utilizados en procesos de separación, y que además deriven (fase futura de este trabajo de investigación) de compuestos orgánicos de bajo coste.

5) Uso de tecnologías conocidas en el campo de los materiales polímeros; en particular usando entrecruzamientos entre las cadenas poliméricas, para mejorar de una forma sencilla, y reduciendo el coste, de membranas de separación de gases con propiedades avanzadas. 


\section{Motivación}

La búsqueda de nuevos materiales de separación de gases con propiedades mejoradas para su aplicación en aplicaciones avanzadas que posean un valor importante tanto a nivel medioambiental como industrial ha sufrido un verdadero hito en la primera década de este siglo con el desarrollo de dos nuevas familias de polímeros:

Polímeros de microporosidad intrínseca, PIMs, los cuales son unos polímeros de tipo escalera (ladder) muy rígidos y donde se ha incorporado un centro de contorsión derivado generalmente de un carbono de naturaleza espiro. Esta conjunción de factores hace que estos materiales posean extraordinarios valores de permeabilidad (similar a algunos polímeros ultraporosos) pero donde la regular disposición de la estructura se manifiesta en una mejor capacidad de discriminar gases. No obstante, y aún cuando la estructura es extremadamente rígida, la existencia probable de irregularidades hace que estos materiales posean un elevado envejecimiento físico y una cierta tendencia a sufrir fenómenos de plastificación. Aun cuando se ha aplicado en este campo un elevado esfuerzo investigador que ha permitido obtener materiales con envejecimiento físico reducido, la dificultad sintética inherente a estos materiales no ha permitido obtener muchos materiales que se puedan aplicar de manera industrial.

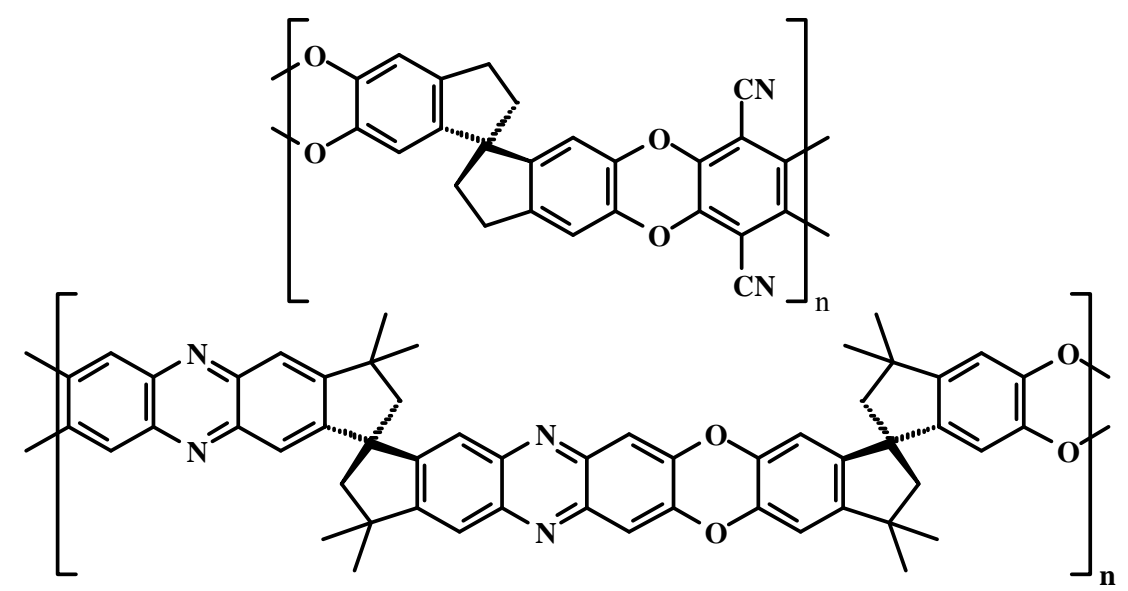

Figura 4. Estructuras químicas de PIMs obtenidos por McKeown y Budd 

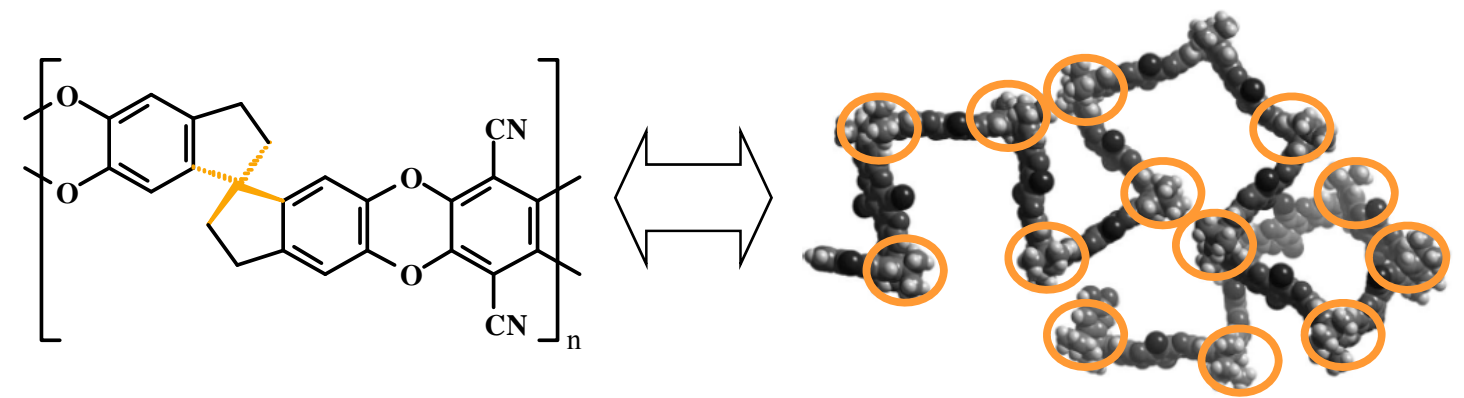

Figura 5. Modelado molecular de un PIM mostrando los plegamientos que impiden el empaquetamiento entre cadenas.

Materiales TR. El otro gran hito apareció en 2007 con el desarrollo de los materiales TR. Los materiales TR se forman mediante tratamiento térmico a altas temperaturas en estado sólido de poliimidas aromáticas conveniente funcionalizadas con grupo $\mathrm{XH}$ $(\mathrm{X}=\mathrm{O}, \mathrm{S}$ o $\mathrm{NH})$ en posición orto al grupo amino. Este tratamiento, y referido a la poliimida que posee grupos $\mathrm{OH}$ (el sistema claramente más empleado debido a la facilidad sintética y menor coste de las o-dihidroxi diaminas aromáticas) produce en este tratamiento una transformación de la orto-hidroxi poliimidas (HPIs) en polibenzoxazoles (TR-PBOs).

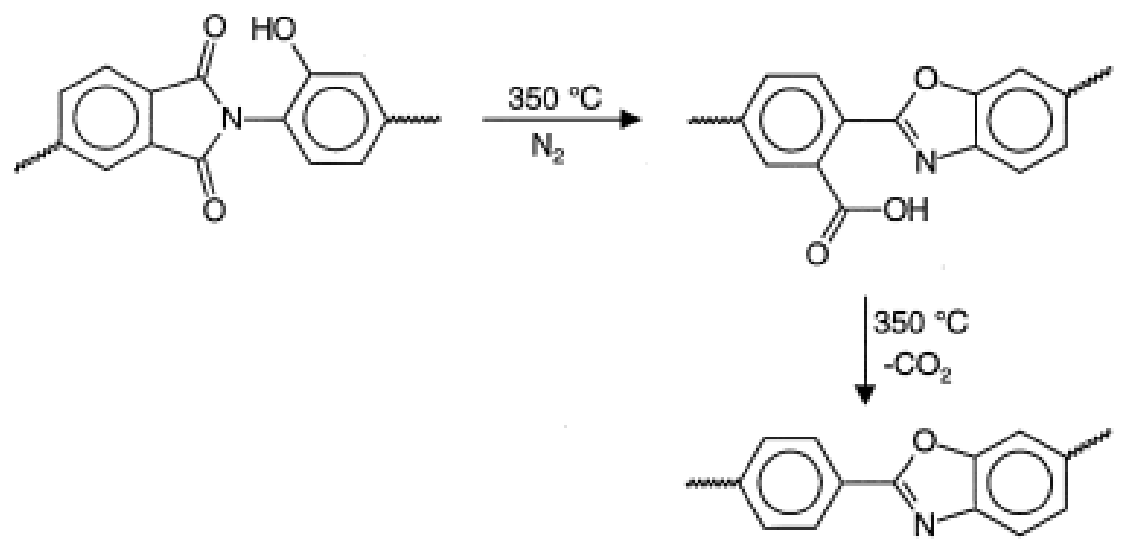

Figura 6. Reacción propuesta para la conversión de hidroxi-poliimidas a polibenzoxazoles

Esta conversión térmica, aunque era conocida antes de este trabajo, no se había empleado en la separación de gases. Tras esta conversión térmica el material formado 
posee unas permeabilidades sobresalientes (superiores en algunos materiales a los 1000 barrer, y en muchos de ellos a los 400 barrer) y una excelente permeoselectividad (de tal modo que estos materiales son capaces de superar el límite de Robeson del 2008.

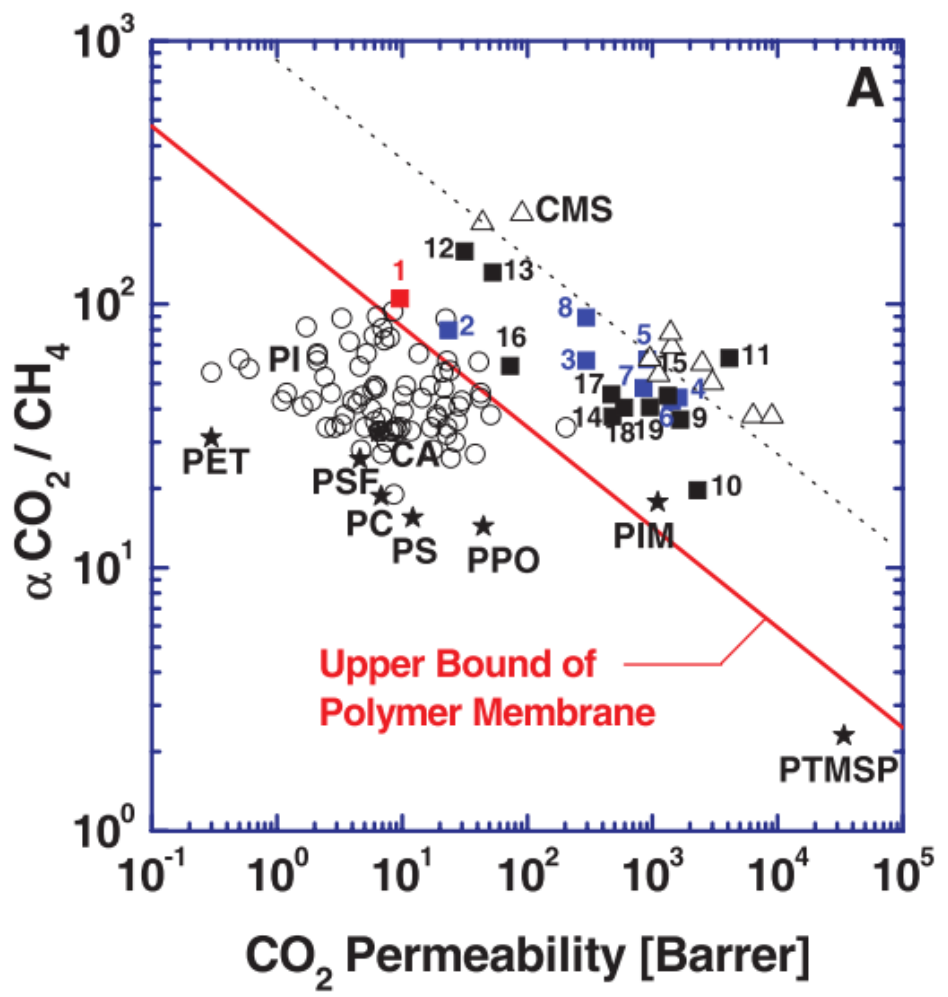

Figure 7. Pares productividad (permeabilidad al CO2)-selectividad (CO2/CH4) de diversos materiales poliméricos. En azul se contemplan algunos de los materiales TR descritos antes de este memoria

La característica de cruzar el límite de Robeson del 2008, hasta la obtención de los PIMs y los TR-PBOS, no se había superado por prácticamente ningún material de naturaleza polimérica). Además, debido a que el proceso de tratamiento térmico a tan altas temperaturas induce un entrecruzamiento del material, se observa que los materiales poseen un envejecimiento físico muy bajo y una tendencia a la plastificación casi nula. Esta combinación de propiedades ha hecho que el esfuerzo investigador en este campo sea muy alto, donde se debe destacar que los grupos más activos son la Universidad de Texas en Austin, EEUU, (Prof. Benny D Freeman) y Hanyang Universidad de Seúl, Corea del Sur (Prof. Young M Lee). Estos grupos han conseguido que estos materiales puedan ser desarrollados en forma de fibras huecas (necesarias para poder conseguir su aplicación industrial). 
No obstante, el desarrollo de los materiales TR debe solucionar una serie de aspectos como son:

1) Necesidad de empleo de temperaturas más bajas que las usadas en la actualidad. Por ello, se deben buscar materiales que posean temperaturas de transición vítrea bastante más bajas

2) Caracterización precisa del proceso de reconversión térmica. En este aspecto es necesario, saber qué es exactamente lo que ocurre durante el tratamiento térmico, y por ello parte de este trabajo de investigación se ha referido a la determinación de los parámetros que pueden dar una mejor idea de cómo es el proceso TR.

3) Mejora importante de las propiedades mecánicas, propiedad negativa que se debe a la concurrencia de degradación térmica junto al proceso de conversión de la orto-hidroxi poliimida (HPI) en polibenzoxazol (TR-PBO). Disminución del envejecimiento físico y aumento de la resistencia a la plastificación.

Este aspecto ha sido un objetivo primario en esta memoria de tesis, donde se ha realizado un estudio pormenorizado de los parámetros necesarios para caracterizar el tratamiento térmico que produce la interconversión de la orto-hidroxi poliimida al polibenzoxazol. También, el método de síntesis de la orto-hidroxipoliimida (HPI) ha sido exhaustivamente realizado, observando que las funciones como membranas de separación de gases de los polibenzoxazoles de ellas derivadas son muy dependientes del método de síntesis.

En la siguiente gráfica se observan los diversos métodos de síntesis empleados: 


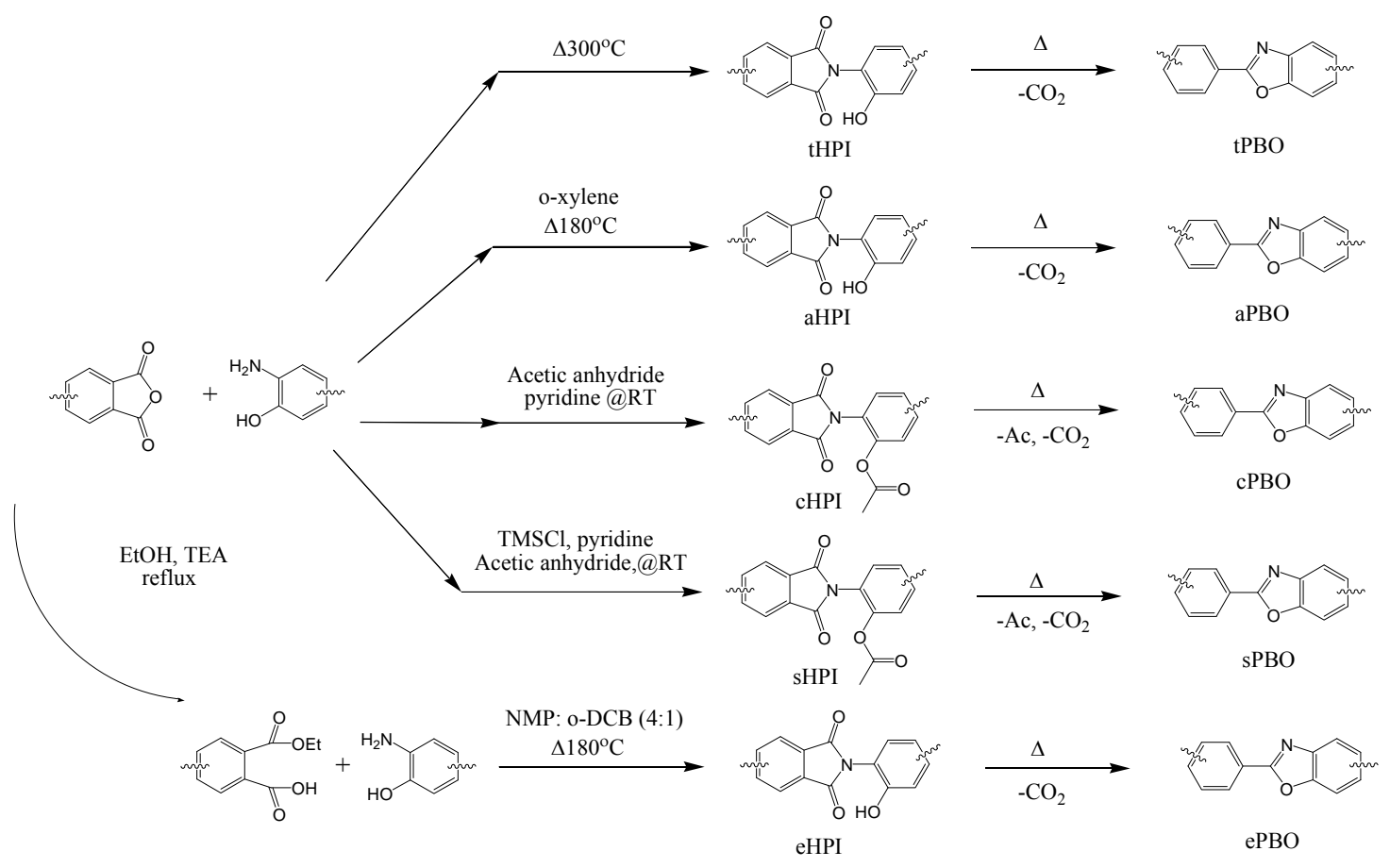

Figura 8. Diversas vías sintéticas para obtener TR-PBOs a partir de precursores de poliimida.

Todos estos métodos han permitido observan las propiedades finales de gases como aparece en el siguiente gráfico:

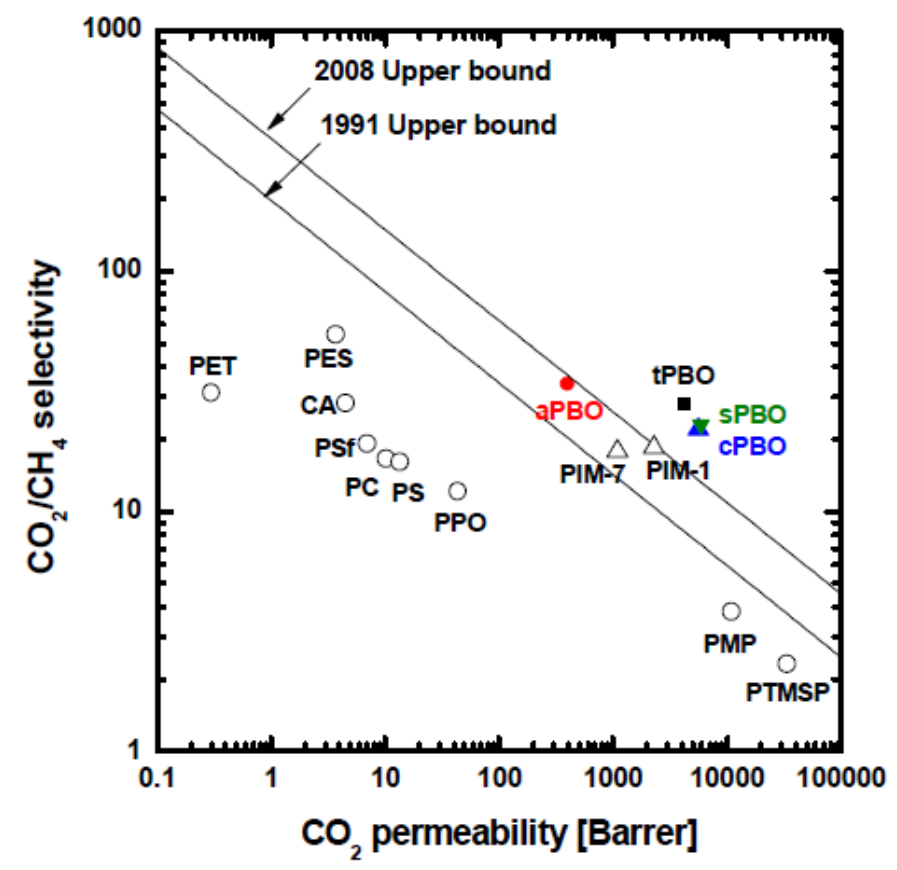

Figure 9. Permeabilidad al $\mathrm{CO}_{2}$ y selectividad de la pareja de gases $\mathrm{CO}_{2} / \mathrm{CH}_{4}$ de membranas TR-PBO obtenidas poor diversos métodos de síntesis 
Este trabajo ha sido muy novedoso y ha permitido extender el diseño de este tipo de materiales de una manera muy racional.

En esta memoria de tesis, se han mejorado las membranas de separación de gases de diversos materiales TR mediante la copolimerización de los precursores TR con otros precursores capaces de sufrir procesos de transposición térmica (orto-hidroxi diaminas $\mathrm{u}$ orto-amino diaminas) o con diaminas aromáticas clásicas. Mediante esta aproximación se han conseguido, después del proceso de reordenamiento térmico; TR-PBO-co-TRPBO, TR-PBO-co-PI y TR-PBO-co-Polypirrolonas (TR-PBO-co-PPL). Estas últimas son materiales con excelentes materiales de separación de gases (debido en particular a la excelente combinación de buena permeabilidad y alta selectividad), que además pueden sufrir otro proceso de la polipirrolona a polibencimidazol. En particular las primeras han generado una serie de TR-PBO-co-TR-PBO con propiedades perfectamente moduladas, y todas ellas materiales de separación de gases excelentes.

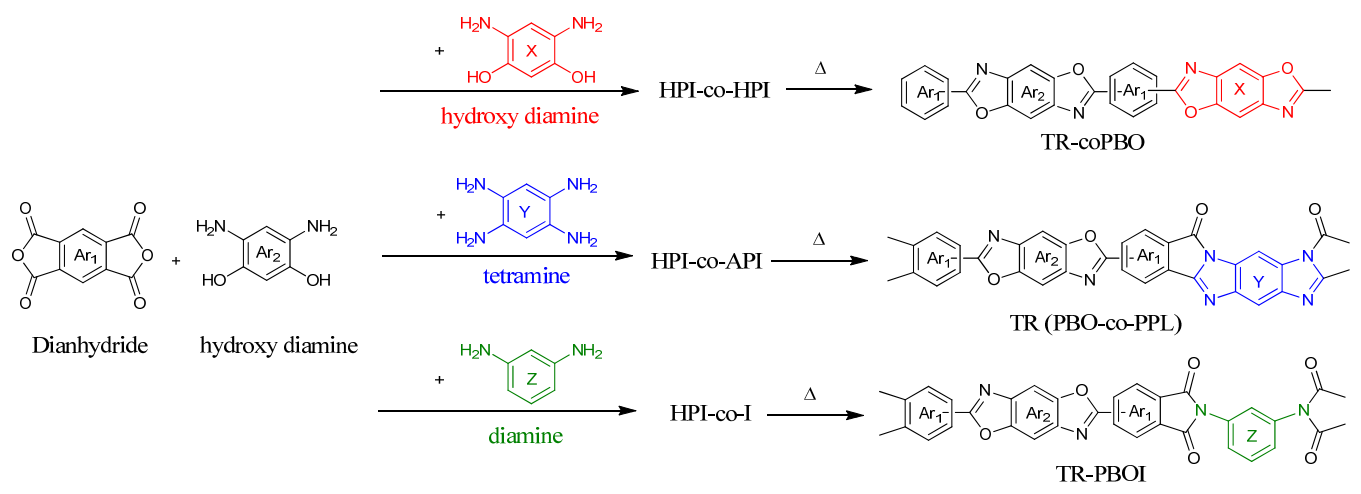

Figura 10. Rutas de copolimerización basadas en doversas diaminas (orto-hidroxi diaminas, orto-amino diaminas y diaminas para preparar TR-PBO-co-TR-PBO, TR-PBO-co-PPL y TRPBO-co-PI, respectivamente

Por ello, se puede decir que gracias al empleo racional de los co-monómeros empelados en esta memoria de tesis doctoral se pueden ajustar las propiedades finales del material, tanto en sus propiedades de permeación de gases, como en otras propiedades que necesitan ser mejoradas para permitir el empleo de los materiales TR en procesos industriales de separación de gases.

En esta tesis se han combinado también las propiedades excelentes de los materiales TR con sistemas de tipo PIM. Este procesos se ha realizado mediante el uso de monómeros TR (es decir con funcionalidades orto-hidroxi) en sistemas orgánicos que poseen uniones de tipo espiránico, las cuales introducen alta rigidez y baja capacidad de generar empaquetamientos eficientes. Gracias a esta aproximación se han conseguido materiales 
con permeabilidades tan altas como de 1200 barrer al $\mathrm{CO}_{2}$. Además el uso de estos sistemas con grupos espiránicos ha permitido obtener materiales con excelentes propiedades mecánicas, mucho más altas que la de todos los polímeros TR descritos en la bibliografía. En la siguiente figura se exponen los monómeros que se han empleado en esta parte del trabajo de investigación.<smiles>CC1(C)CC2(c3cc4c(cc3CC2(C)C)C(=O)OC4=O)c2cc3c(cc21)C(=O)OC3=O</smiles>

(a)<smiles>CC1(C)CC2(c3cc(O)c(N)cc3CC2(C)C)c2cc(O)c(N)cc21</smiles>

(c)

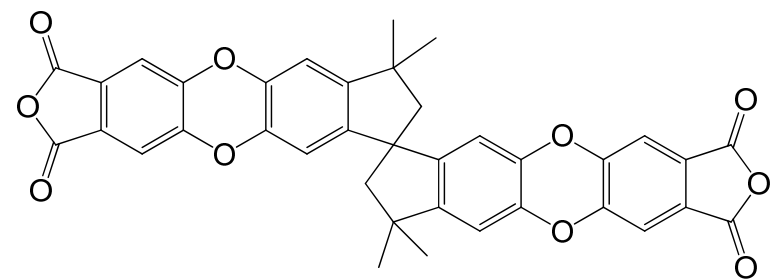

(b)

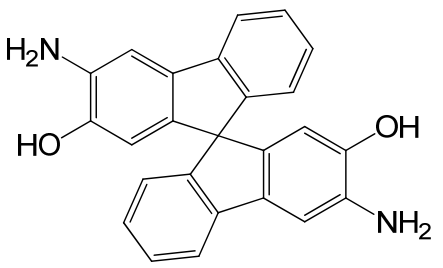

(d)

Figura 11. Estructras químicas de diversas estructuras que poseen carbonos espiránicos. (a) dianhídrido basado en espirobisindano (SPDA1), (b) dianhídrido basado en espirobisindano 2 (SPDA2), (c) 3,3,3',3'-tetrametil-1,1'-espirobisindano-5,5'-diamino-6,6'-diol (TDSS), y (d) 2,2'-dihidroxi-9.9'-espirobifluoreno-2,2'-diamina (HSBF).

Finalmente, en esta memoria de tesis doctoral se presenta una nueva aproximación, que ha consistido en copolimerizar monómeros TR con diaminas que porten funcionalidades (grupos carboxílicos) en polímeros precursores precisamente obtenidos. Estos copolímeros con grupos carboxílicos pueden ser entrecruzados mediante vías químicas (dioles o diaminas) obteniéndose materiales que poseen entrecruzamientos de de unidades ésteres con mucho mejores propiedades. Además, en la fase final de formación TR, los grupos ésteres son eliminados, generándose TR-polibenzoxazoles con menor envejecimiento físico y mejores propiedades mecánicas. 


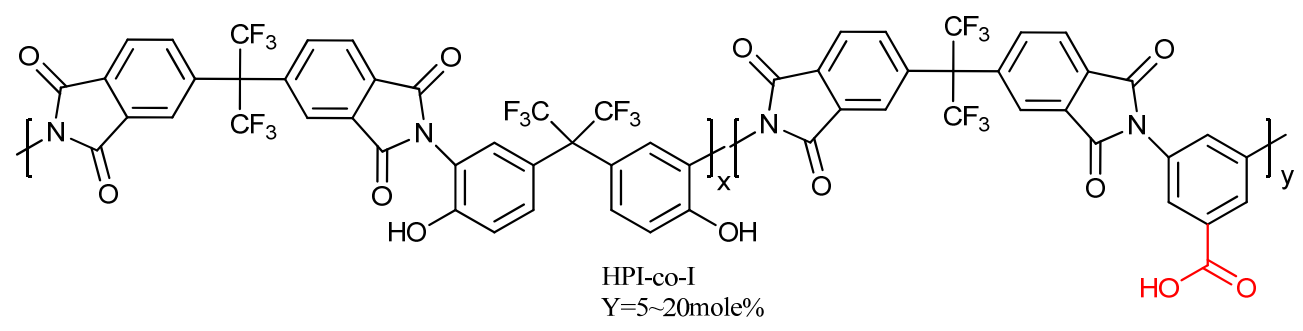
-toluenesulfonic acid Butylene glycol $140^{\circ} \mathrm{C}, 18 \mathrm{~h}$

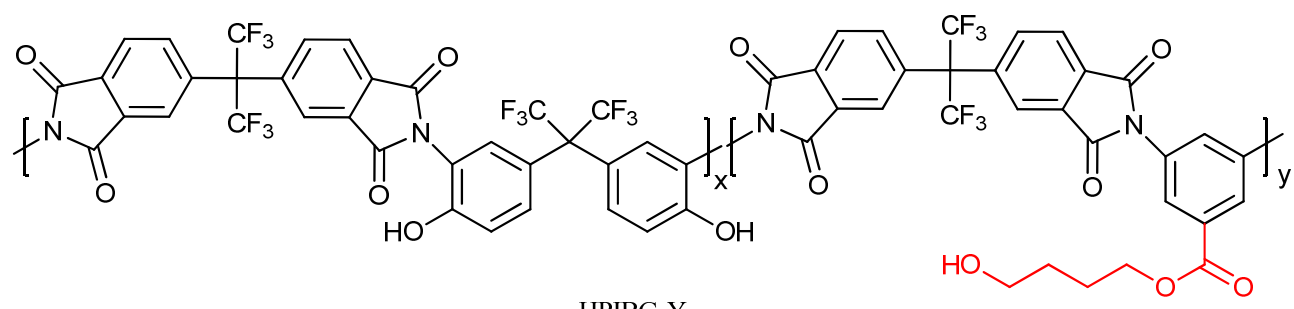
HPIBG-Y

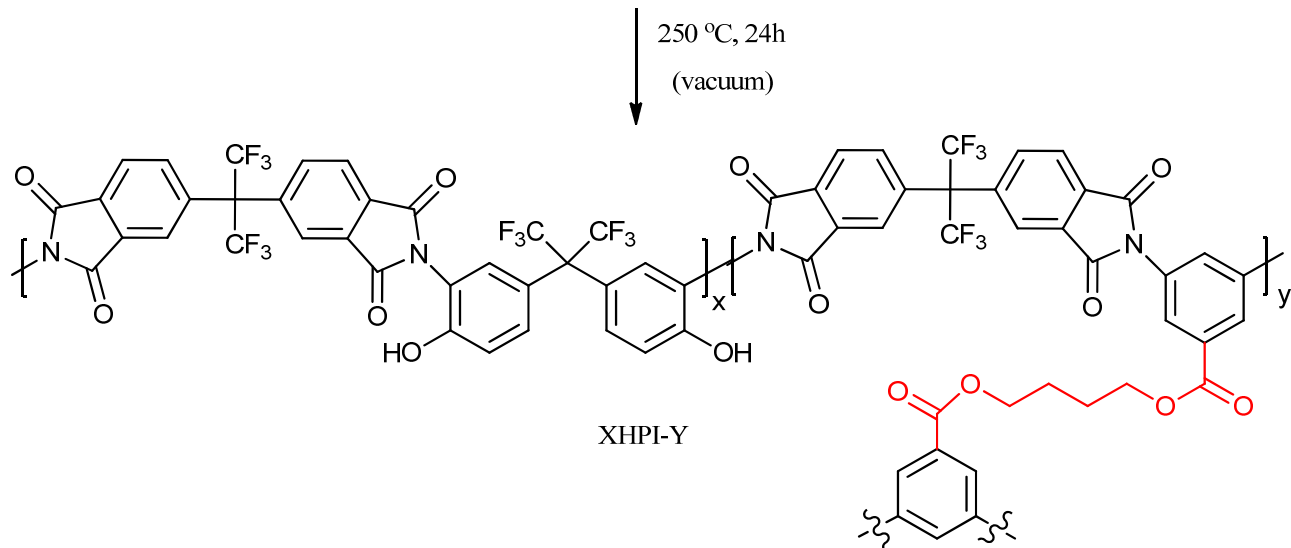
$\underset{(\mathrm{Ar})}{450^{\circ} \mathrm{C}, 1 \mathrm{~h}}$

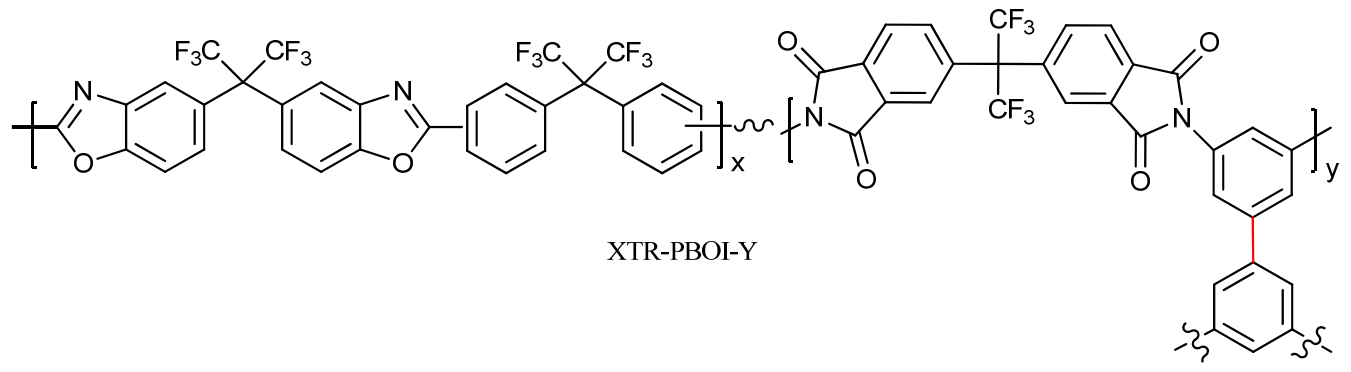

Figura 12. (a) Manera química de preparar XTR-PBOIs (X-TRP-PBO-Co-PI)s por reacción de transesterificacion con butanodiol y (b) Preparación térmicamente inducida de XTRPBOIs (X-TRP-PBO-Co-PI)a partir de hidroxi copoliimida (HPI-co-PI) por tratamiento térmico en atmósfera de argón. 


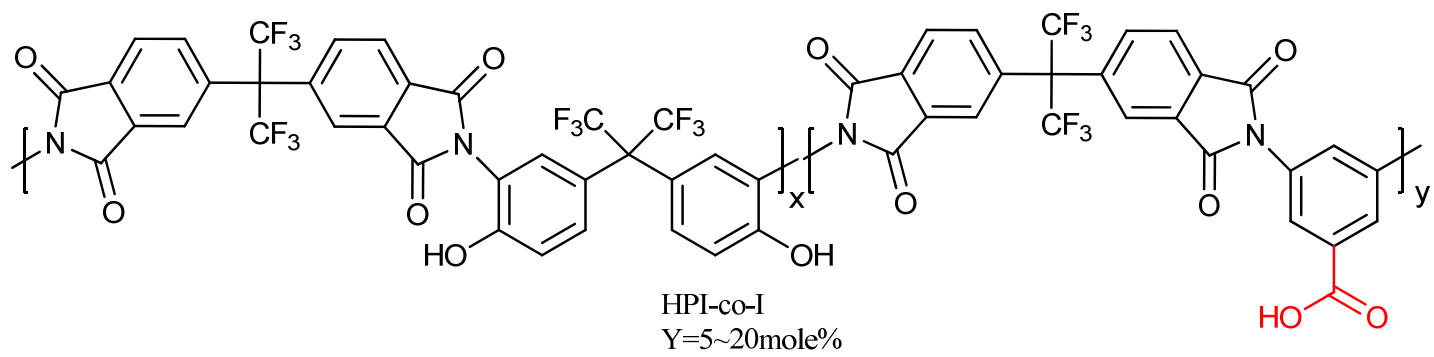

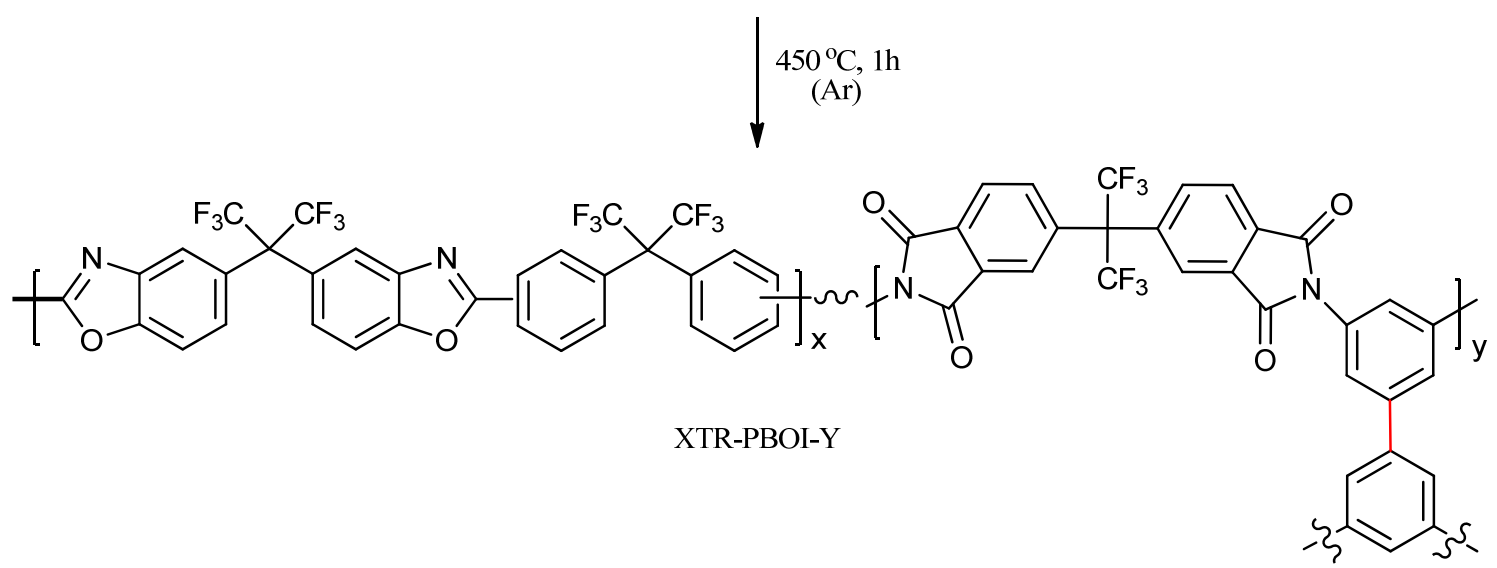

Figura 13 Formación de TR-PBO entrecruzados mediante tratamiento térmicos de hidroxi poliimides-co-poliimidas que portan grupos carboxílicos. El entrecriuzameinto se produce por descarboxilación de los grupos ácidos, entrecruzamiento y formación simuoltanea o no del TR-PBO. 
Conclusiones generales del trabajo de Investigación ofrecido en esta memoria de Tesis Doctoral

La nueva generación de materiales polímeros obtenidos por tratamientos térmicos de precursores de poliimida (generalmente orto-hidroxi poliimidas (HPIs) aunque es factible ese proceso desde orto-tiol poliimidas u orto-amino poliimidas), los cuales producen un reordenamiento térmico de estos precursores a materiales TR, polibenzoxazoles $\mathrm{u}$ otros tipos de poli(1,3-benzoazoles; polibenzotiazoles $\mathrm{o}$ polipirrolonas (las cuales derivan si el tratamiento térmico es más intenso a polibencimidazoles), ha permitido obtener membranas con sobresalientes propiedades de separación, ya que presentan permeabilidades (flujos) muy elevadas y razonables selectividades (capacidad de discriminar una mezcla de gases en sus componentes) . La capacidad de adecuar las propiedades finales mediante un diseño racional es de elevada importancia si lo que se busca es obtener materiales capaces de ser empleados por la industria.

Para que esta aplicación industrial sea posible es necesario hacer una serie de mejoras. Para producir esas mejoras es necesario un conocimiento real del proceso de reconversión térmica (proceso TR) y la búsqueda de relaciones entre propiedades de transporte y estructura. En particular, la nueva generación de materiales TR que se desarrolle tiene que poseer excelentes propiedades mecánicas, de largos mejores que las que se conocían antes de esta memoria de investigación.

Por ello, mediante el uso de un buen diseño de los monómeros de partida, mediante el uso de métodos de copolimerización, y el uso de tecnologías de entrecruzamiento de las cadenas poliméricas se han obtenido unos materiales muy competitivos, y que tienen capacidad para ser empleados de manera industrial. Al mismo tiempo, en este trabajo de investigación se han obtenido relaciones entre la temperatura de tratamiento, el método de síntesis de los precursores de poliimida, y las propiedades finales de los materiales. Todo ello, y recalcando que los materiales desarrollados poseen excelente propiedades finales, puede permitir avanzar aún más en futuros trabajos de investigación, utilizando métodos racionales de diseño. 


\section{Bibliografía General del Resumen en Español}

L.M. Robeson, W.F. Burgoyne, M. Langsam, A.C. Savoca, C.F. Tien, High performance polymers for membrane separation, Polymer (Guildf). 35 (1994) 4970-4978. doi:10.1016/0032-3861(94)90651-3.

L.M. Robeson, Correlation of separation factor versus permeability for polymeric membranes, J. Memb. Sci. 62 (1991) 165-185.

L. M. Robeson, Polymer membranes for gas separation, Curr. Opin. Solid State Mater. Sci. 4 (1999) 549-552.

L.M. Robeson, The upper bound revisited, J. Memb. Sci. 320 (2008) 390-400. doi:10.1016/j.memsci.2008.04.030.

L.M. Robeson, B.D. Freeman, D.R. Paul, B.W. Rowe, An empirical correlation of gas permeability and permselectivity in polymers and its theoretical basis, J. Memb. Sci. 341 (2009) 178-185. doi:10.1016/j.memsci.2009.06.005.

B.D. Freeman, Basis of Permeability/Selectivity Tradeoff Relations in Polymeric Gas Separation Membranes, Macromolecules. $32 \quad$ (1999) 375-380. http://dx.doi.org/10.1021/ma9814548.

K. Vanherck, G. Koeckelberghs, I.F.J. Vankelecom, Crosslinking polyimides for membrane applications: A review, Prog. Polym. Sci. 38 (2013) 874-896. doi:10.1016/j.progpolymsci.2012.11.001.

D. Aaron, C. Tsouris, Separation of CO2 from Flue Gas: A Review, Sep. Sci. Technol. 40 (2005) 321-348. http://www.informaworld.com/10.1081/SS-200042244.

J.K. Adewole, A.L. Ahmad, S. Ismail, C.P. Leo, Current challenges in membrane separation of CO2 from natural gas: A review, Int. J. Greenh. Gas Control. 17 (2013) 4665 .

G. Scheffknecht, L. Al-Makhadmeh, U. Schnell, J. Maier, Oxy-fuel coal combustion-A review of the current state-of-the-art, Int. J. Greenh. Gas Control. 5 (2011) 16-35. doi:10.1016/j.ijggc.2011.05.020. 
Y. Xiao, B.T. Low, S.S. Hosseini, T.S. Chung, D.R. Paul, The strategies of molecular architecture and modification of polyimide-based membranes for $\mathrm{CO} 2$ removal from natural gas-A review, Prog. Polym. Sci. 34 (2009) 561-580. doi:10.1016/j.progpolymsci.2008.12.004.

P. Bernardo, E. Drioli, G. Golemme, Membrane gas separation: A review/state of the art, Ind. Eng. Chem. Res. 48 (2009) 4638-4663.

Y. Zhang, J. Sunarso, S. Liu, R. Wang, Current status and development of membranes for CO2/CH4 separation: A review, Int. J. Greenh. Gas Control. 12 (2013) 84-107.

L.S. Penn, H. Wang, Chemical modification of polymer surfaces: A review, Polym. Adv. Technol. 5 (1994) 809-817. doi:10.1002/pat.1994.220051207.

R. Wang, C. Cao, T.-S. Chung, A critical review on diffusivity and the characterization of diffusivity of 6FDA-6FpDA polyimide membranes for gas separation, J. Memb. Sci. 198 (2002) 259-271. doi:10.1016/S0376-7388(01)00665-2.

D. Aaron, C. Tsouris, Separation of CO2 from Flue Gas: A Review, Sep. Sci. Technol. 40 (2005) 321-348. http://www.informaworld.com/10.1081/SS-200042244.

S.D. Kelman, B.W. Rowe, C.W. Bielawski, S.J. Pas, A.J. Hill, D.R. Paul, et al., Crosslinking poly[1-(trimethylsilyl)-1-propyne] and its effect on physical stability, J. Memb. Sci. 320 (2008) 123-134. doi:10.1016/j.memsci.2008.03.064.

Q. Song, S. Cao, R.H. Pritchard, B. Ghalei, S. a. Al-Muhtaseb, E.M. Terentjev, et al., Controlled thermal oxidative crosslinking of polymers of intrinsic microporosity towards tunable molecular sieve membranes, Nat. Commun. 5 (2014) 4813. doi:10.1038/ncomms5813.

C. Staudt-Bickel, W. J. Koros, Improvement of $\mathrm{CO} 2 / \mathrm{CH} 4$ separation characteristics of polyimides by chemical crosslinking, J. Memb. Sci. 155 (1999) 145-154. doi:10.1016/S0376-7388(98)00306-8. 
J.D. Wind, C. Staudt-Bickel, D.R. Paul, W.J. Koros, The Effects of Crosslinking Chemistry on CO 2 Plasticization of Polyimide Gas Separation Membranes, Ind. Eng. Chem. Res. 41 (2002) 6139-6148. doi:10.1021/ie0204639.

L. Liu, E.S. Sanders, S.S. Kulkarni, D.J. Hasse, W.J. Koros, Sub-ambient temperature flue gas carbon dioxide capture via Matrimid® hollow fiber membranes, J. Memb. Sci. 465 (2014) 49-55. doi:10.1016/j.memsci.2014.03.060.

D. Ayala, A.E. Lozano, J. De Abajo, J.G. De La Campa, Synthesis and Characterization of Novel Polyimides with Bulky Pendant Groups, J. Polym. Sci. Part A Polym. Chem. 37 (1999) 805-814. http://www.scopus.com/inward/record.url?eid=2-s2.00033098460\&partnerID=tZOtx3y1.

D.M. Muñoz, M. Calle, A.E. Lozano, J.G. De Campa, An improved method of preparing high molecular weight polyimides. base-assisted in situ silylation of diamines, 49 (2008) 723-724.

C. García, A.E. Lozano, J.G. de la Campa, J. de Abajo, Soluble Polyimides from a New Dianhydride: 5'-tert-Butyl-m-terphenyl-3,4,3",4"-tetracarboxylic Acid Dianhydride, Macromol. Rapid Commun. 24 (2003) 686-691. doi:10.1002/marc.200350014.

J.G. de la Campa, C. Tauler, A.E. Lozano, J. de Abajo, Polyimides from 3, 4: 3 ", 4 "-mterphenyltetracarboxylic dianhydride. Synthesis and characterization, Macromol. Rapid Commun. 15 (1994) 417-424.

M. Calle, C. García, A.E. Lozano, J.G. De la Campa, J. De Abajo, C. Álvarez, Local chain mobility dependence on molecular structure in polyimides with bulky side groups: Correlation with gas separation properties, J. Memb. Sci. 434 (2013) 121-129. doi:10.1016/j.memsci.2013.01.054.

J. De Abajo, J.G. De la Campa, A.E. Lozano, J. Espeso, C. García, Designing Aromatic Polyamides and Polyimides for Gas Separation Membranes, Macromol. Symp. 199 (2003) 293-305. doi:10.1002/masy.200350925. 
J.F. Espeso, Á.E. Lozano, J.G. de la Campa, Í. García-Yoldi, J. de Abajo, Synthesis and properties of new aromatic polyisophthalamides with adamantylamide pendent groups, J. Polym. Sci. Part A Polym. Chem. 48 (2010) 1743-1751. doi:10.1002/pola.23939.

D.M. Muñoz, J.G. de la Campa, J. de Abajo, A.E. Lozano, Experimental and Theoretical Study of an Improved Activated Polycondensation Method for Aromatic Polyimides, Macromolecules. 40 (2007) 8225-8232. doi:10.1021/ma070842j.

D.F. Sanders, Z.P. Smith, R. Guo, L.M. Robeson, J.E. McGrath, D.R. Paul, et al., Energyefficient polymeric gas separation membranes for a sustainable future: A review, Polym. (United Kingdom). 54 (2013) 4729-4761. doi:10.1016/j.polymer.2013.05.075.

P. Budd, N.B. McKeown, B. Ghanem, K. Msayib, D. Fritsch, L. Starannikova, et al., Gas permeation parameters and other physicochemical properties of a polymer of intrinsic microporosity: Polybenzodioxane PIM-1, J. Memb. Sci. 325 (2008) 851-860. doi:10.1016/j.memsci.2008.09.010.

H. Shamsipur, B. a. Dawood, P.M. Budd, P. Bernardo, G. Clarizia, J.C. Jansen, Thermally Rearrangeable PIM-Polyimides for Gas Separation Membranes, Macromolecules. 47 (2014) 5595-5606. doi:10.1021/ma5011183.

W.F. Yong, F.Y. Li, T.-S. Chung, Y.W. Tong, Highly permeable chemically modified PIM-1/Matrimid membranes for green hydrogen purification, J. Mater. Chem. A. 1 (2013) 13914. doi:10.1039/c3ta13308g.

R. Swaidan, B.S. Ghanem, E. Litwiller, I. Pinnau, Pure- and mixed-gas CO2/CH4 separation properties of PIM-1 and an amidoxime-functionalized PIM-1, J. Memb. Sci. 457 (2014) 95-102. doi:10.1016/j.memsci.2014.01.055.

N. Du, G.P. Robertson, J. Song, I. Pinnau, M.D. Guiver, M. Park, High-Performance Carboxylated Polymers of Intrinsic Microporosity ( PIMs ) with Tunable Gas Transport Properties $\dagger$, (2009) 6038-6043. doi:10.1021/ma9009017. 
N. Du, G.P. Robertson, J. Song, I. Pinnau, M.D. Guiver, High-Performance Carboxylated Polymers of Intrinsic Microporosity (PIMs) with Tunable Gas Transport Properties †, Macromolecules. 42 (2009) 6038-6043. doi:10.1021/ma9009017.

M. Heuchel, D. Fritsch, P.M. Budd, N.B. McKeown, D. Hofmann, Atomistic packing model and free volume distribution of a polymer with intrinsic microporosity (PIM-1), J. Memb. Sci. 318 (2008) 84-99. doi:10.1016/j.memsci.2008.02.038.

B.S. Ghanem, N.B. McKeown, P.M. Budd, N.M. Al-Harbi, D. Fritsch, K. Heinrich, et al., Synthesis, Characterization, and Gas Permeation Properties of a Novel Group of Polymers with Intrinsic Microporosity: PIM-Polyimides, Macromolecules. 42 (2009) 7881-7888. doi:10.1021/ma901430q.

S. Thomas, I. Pinnau, N. Du, M.D. Guiver, Pure- and mixed-gas permeation properties of a microporous spirobisindane-based ladder polymer 2009. doi:10.1016/j.memsci.2009.02.003.

H.B. Park, C.H. Jung, Y.M. Lee, A.J. Hill, S.J. Pas, S.T. Mudie, et al., Polymers with cavities tuned for fast selective transport of small molecules and ions., Science. 318 (2007) 254-8. doi:10.1126/science.1146744.

M. Calle, Y.M. Lee, Thermally Rearranged (TR) Poly(ether-benzoxazole) Membranes for Gas Separation, Macromolecules. 44 (2011) 1156-1165. doi:10.1021/ma102878z.

M. Calle, A.E. Lozano, Y.M. Lee, Formation of thermally rearranged (TR) polybenzoxazoles: Effect of synthesis routes and polymer form, Eur. Polym. J. 48 (2012) $1313-1322$.

S. Kim, H.J. Jo, Y.M. Lee, Sorption and transport of small gas molecules in thermally rearranged (TR) polybenzoxazole membranes based on 2,2-bis(3-amino-4-hydroxyphenyl)hexafluoropropane (bisAPAF) and 4,4'-hexafluoroisopropylidene diphthalic anhydride (6FDA), J. Memb. Sci. 441 (2013) 1-8. doi:10.1016/j.memsci.2013.03.054. 
S. Li, H.J. Jo, S.H. Han, C.H. Park, S. Kim, P.M. Budd, et al., Mechanically robust thermally rearranged (TR) polymer membranes with spirobisindane for gas separation, J. Memb. Sci. 434 (2013) 137-147. doi:10.1016/j.memsci.2013.01.011.

R. Guo, D.F. Sanders, Z.P. Smith, B.D. Freeman, D.R. Paul, J.E. McGrath, Synthesis and characterization of Thermally Rearranged (TR) polymers: influence of ortho-positioned functional groups of polyimide precursors on TR process and gas transport properties, J. Mater. Chem. A. 1 (2013) 262. doi:10.1039/c2ta00799a.

C.H. Park, E. Tocci, Y.M. Lee, E. Drioli, Thermal treatment effect on the structure and property change between hydroxy-containing polyimides (HPIs) and thermally rearranged polybenzoxazole (TR-PBO),, J. Phys. Chem. B. 116 (2012) 12864-77. doi:10.1021/jp307365y.

J.I. Choi, C.H. Jung, S.H. Han, H.B. Park, Y.M. Lee, Thermally rearranged (TR) poly(benzoxazole-co-pyrrolone) membranes tuned for high gas permeability and selectivity, J. Memb. Sci. 349 (2010) 358-368. doi:10.1016/j.memsci.2009.11.068.

R. Guo, D.F. Sanders, Z.P. Smith, B.D. Freeman, D.R. Paul, J.E. McGrath, Synthesis and characterization of Thermally Rearranged (TR) polymers: influence of ortho-positioned functional groups of polyimide precursors on TR process and gas transport properties, J. Mater. Chem. A. 1 (2013) 262-272. doi:10.1039/C2TA00799A.

C.H. Park, E. Tocci, Y.M. Lee, E. Drioli, Thermal treatment effect on the structure and property change between hydroxy-containing polyimides (HPIs) and thermally rearranged polybenzoxazole (TR-PBO), J. Phys. Chem. B. 116 (2012) 12864-12877.

C.Y. Soo, H.J. Jo, Y.M. Lee, J.R. Quay, M.K. Murphy, Effect of the chemical structure of various diamines on the gas separation of thermally rearranged poly(benzoxazole-co-imide) (TR-PBO-co-I) membranes, J. Memb. Sci. $444 \quad$ (2013) 365-377. doi:10.1016/j.memsci.2013.05.056. 
Q.M. Malik, S. Ijaz, D.C. Craig, A.C. Try, € ger's base analogues Synthesis and reactivity of dimethoxy-functionalised $\operatorname{Tr} \quad$ o, Tetrahedron. $67 \quad$ (2011) 5798-5805. doi:10.1016/j.tet.2011.05.128.

S.H. Han, N. Misdan, S. Kim, C.M. Doherty, A.J. Hill, Y.M. Lee, Thermally Rearranged (TR) Polybenzoxazole: Effects of Diverse Imidization Routes on Physical Properties and Gas Transport Behaviors, Macromolecules. $43 \quad$ (2010) 7657-7667. doi:10.1021/ma101549z.

Y. Jiang, F.T. Willmore, D. Sanders, Z.P. Smith, C.P. Ribeiro, C.M. Doherty, et al., Cavity size, sorption and transport characteristics of thermally rearranged (TR) polymers, Polymer (Guildf). 52 (2011) 2244-2254. doi:10.1016/j.polymer.2011.02.035. 



\section{CONTENTS}

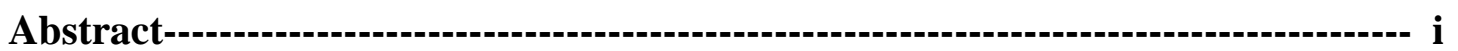

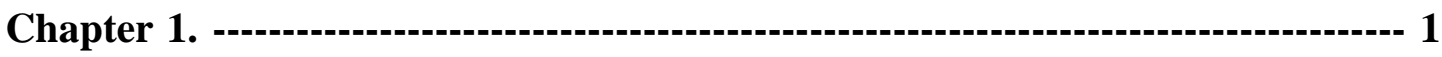

Introduction: Recent High Performance Polymeric Membranes for Gas Separation

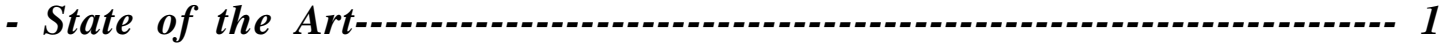

1.1. Introduction ------------------------------------------------------------------------------ 2

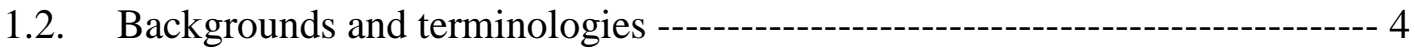

1.3. Applications using polymeric membranes ------------------------------------- 15

1.4. Emerging high-permeable polymer membranes ------------------------------- 17

1.5. Thermally rearranged polymers-------------------------------------------------- 21

1.5.1. TR- $\alpha-P B O$ and TR- $\beta$-PBO------------------------------------------------------- 22

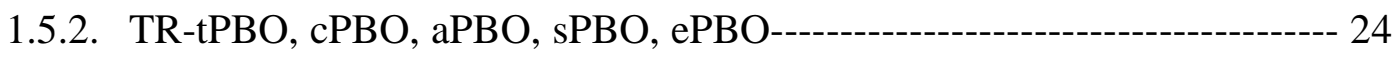

1.5.3. Thermally Rearranged Copolymers-------------------------------------------- 28

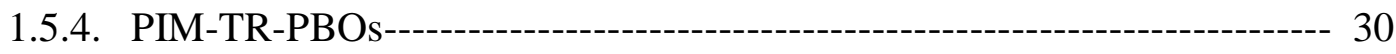

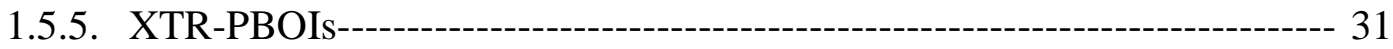

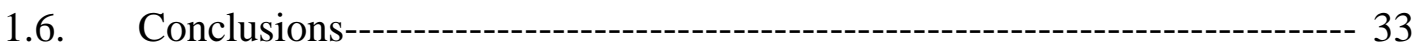

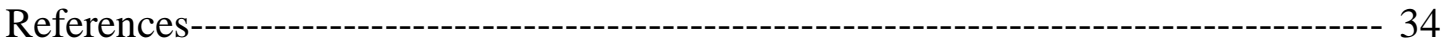

Chapter 2.---------------------------------------------------------------------------------- 44

The Relationship between the Chemical Structure and Thermal Conversion Temperatures of Thermally Rearranged (TR) Polymers---:------------:----------- 44

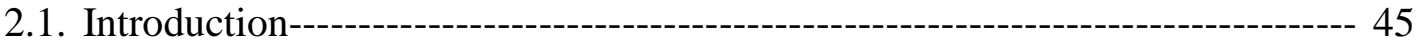

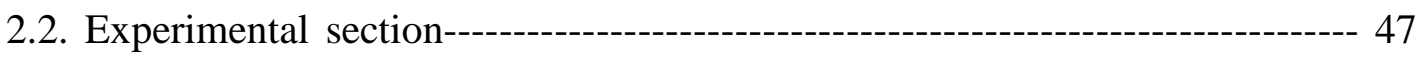

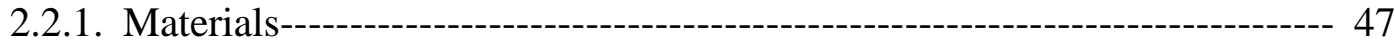


2.2.2. Monomer Synthesis------------------------------------------------------------ 48

2.2.3. Poly(o-hydroxyimide)s synthesis------------------------------------- 50

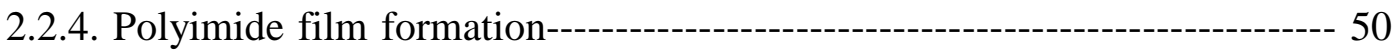

2.2.5. Measurements ----------------------------------------------------------------------- 51

2.3. Results and discussions--------------------------------------------------- 52

2.3.1. Monomer synthesis--------------------------------------------------------------- 52

2.3.2. Synthesis of hydroxyl-containing precursor polyimides and copolyimides----

2.3.3. Thermal rearrangement temperature $\left(\mathrm{T}_{\mathrm{TR}}\right)$----------------------------- 59

2.3.4. Relationship between Tg and TTR-------------------------------------------- 61

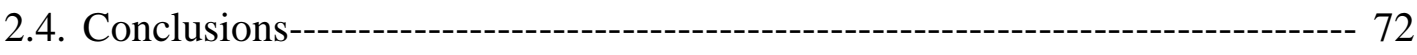

References------------------------------------------------------------------------------------------ 73

Chapter 3. ---------------------------------------------------------------------- 75

Thermally Rearranged Poly(benzoxazole-co-imide) Membranes with Superior Mechanical Strength for Gas Separation Obtained by Tuning Chain Rigidity-----75

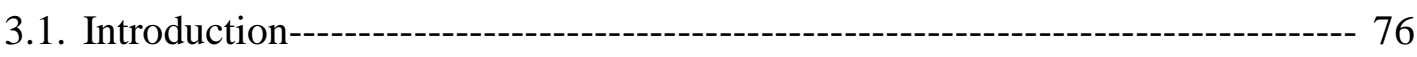

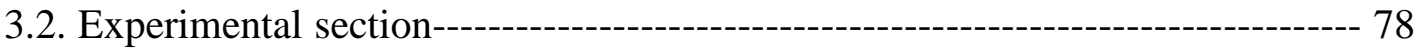

3.2.1. Materials---------------- 78

3.2.2. Polymer synthesis and membrane fabrication-------------------------------- 79

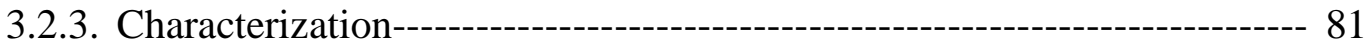

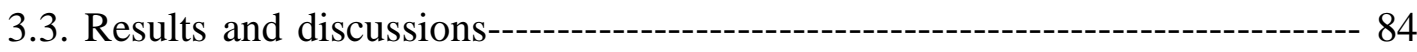

3.3.1. Physical properties of precursor hydroxyl copolyimides and thermal rearrangement to TR-PBOIs------------------------------------------- 84

3.3.2 Mechanical properties of TR-PBOI membranes------------------------ 92

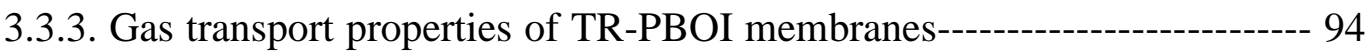


3.4. Conclusions-----o- 103

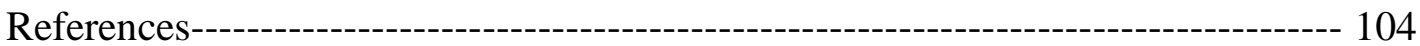

Chapter 4. ------------------------------------------------------------------------------ 109

Mechanically robust thermally rearranged (TR) polymer membranes with spirobisindane for gas separation--- 109

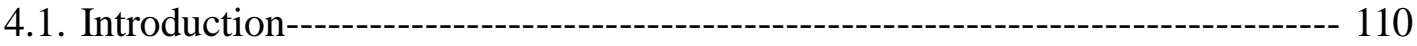

4.2. Experimental section-------------------------------------------------------- 114

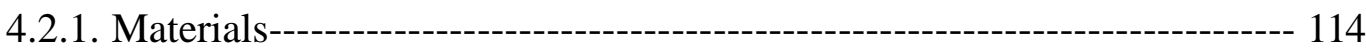

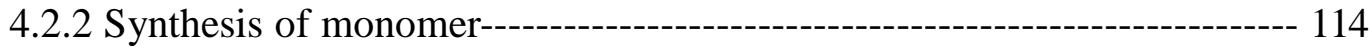

4.2.3. Synthesis of spiro-hydroxyl polyimides via poly(amic acid) ------------- 117

4.2.4. Preparation of spiroTR-PBO membranes---------------------------------- 118

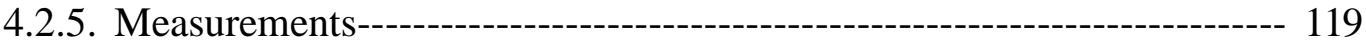

4.3. Results and discussions-------------------------------------------------------- 123

4.3.1. Synthesis of monomer, spiroHPIs and spiroTR-PBO membranes------- 123

4.3.2. Physical properties------------------------------------------------------------ 129

4.3.3. Mechanical properties------------------------------------------------------- 133

4.3.4. Gas transport properties------------------------------------------------- 138

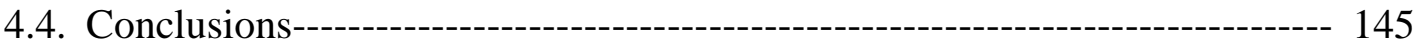

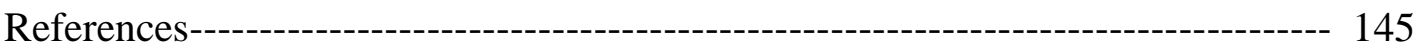

Chapter 5. ------------------------------------------------------------------------------ 154

Cross-linking Effect on the Microstructure and Gas Transport Properties of Thermally Rearranged Poly(benzoxazole-co-imide)s----------------------- 154

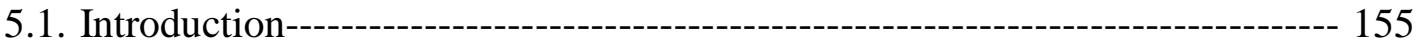




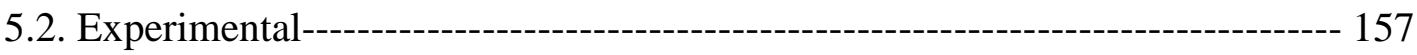

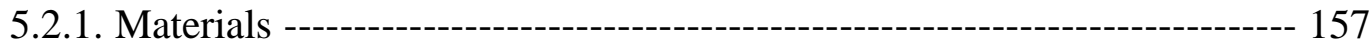

5.2.2. Synthesis of hydroxyl copolyimides ------------------------------------- 157

5.2.3. Preparation of hydroxyl copolyimide membranes ---------------------- 158

5.2.4. Preparation of cross-linked hydroxyl copolyimides and thermally rearranged poly(benzoxazole-co-imide) Membranes ---------------------------- 158

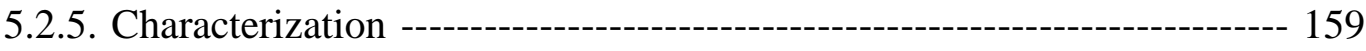

5.3. Results and discussions-------------------------------------------- 162

5.3.1. Preparation and characterization of hydroxyl copolyimides (HPI) and subTg cross-linked hydroxyl copolyimides (XHPI) ---------------------- 162

5.3.2. Effect of thermal treatment protocol on cross-linking ---------------- 167 5.3.3. Sub-Tg thermal cross-linking and thermal rearrangement of cross-linked hydroxyl copolyimide (XHPI) into poly(benzoxazole-co-imide) (XTR-PBOI) ----

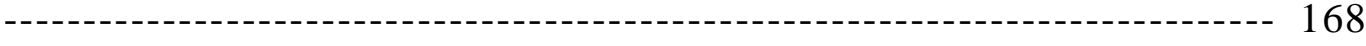

5.3.4. Effect of cross-linking on physical properties. --------------------------- 176

5.3.5. Effect of cross-linking on pure gas transport properties. ----------------- 179

5.3.6. Effect of cross-linking on mixed gas permeation and plasticization.-- 185

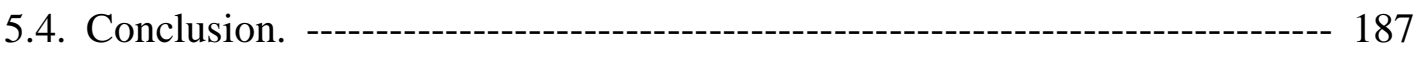

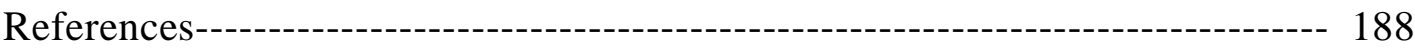

Chapter 6. ---------------------------------------------------------------------- 193

Cross-linking effect on Thermally Rearranged Hollow Fiber Membranes-------- 193

6.1. Introduction----------------------------------------------------- 194

6.2. Experimental---------------------------------------------------------------- 195

6.2.1. Materials--------------------------------------------------------------------------- 195

6.2.2. Preparation of dense and hollow fiber membranes ------------------------ 196 
6.2.3. Characterization------o--- 197

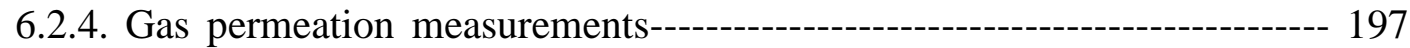

6.3. Results and Discussions---_- 200

6.3.1. Preparation of polymer and dense membrane--------------------------------- 200

6.3.2. Preparation of hollow fiber membranes, gas permeation and effect of cross-

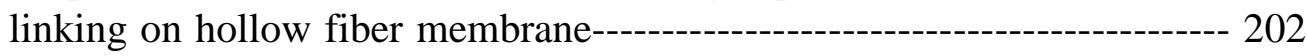

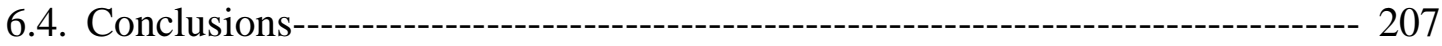

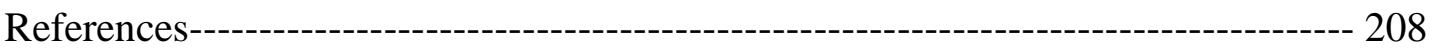

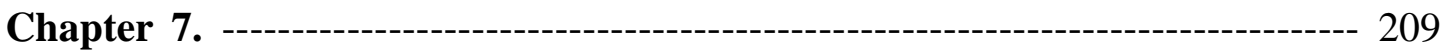

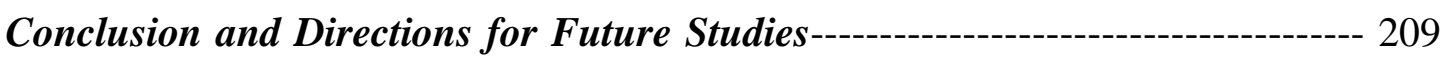

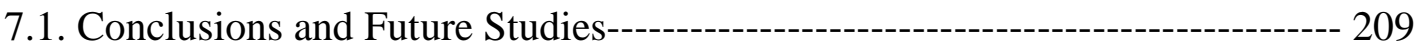

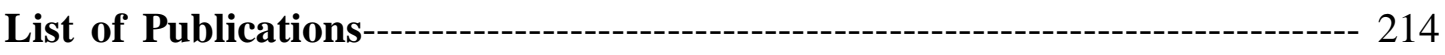




\section{Abstract}

This $\mathrm{PhD}$ dissertation is mainly focused on the development of novel thermally rearranged copolymers intending to apply for gas separation membranes. It is targeted to developing novel copolymer membranes based on thermally rearranged polybenzoxazole (TR-PBO) and analyzing the relationships between chemical structures and physical properties as well as gas transport properties. This work focused on improving not only gas permeabilities also mechanical properties for practical gas separation applications.

This dissertation is organized into six chapters including the introduction (Chapter 1), four main research parts (Chapter 2-6) and conclusion (Chapter 7).

Chapter 1 introduces the state of the art of polymeric membranes in gas separation applications, the mechanisms of gas transport through solid state polymer membranes and the summary of development of thermally rearranged polymers for gas separation membranes for last decade.

Chapter 2 introduces the relationship between the thermal properties and the structures of the precursor polymers including several hydroxy polyimides and hydroxy copolyimides. Various chemical structures of precursor polymers were obtained by combining different dianhydrides and hydroxy diamines. In this study, three thermal rearrangement temperatures $\left(\mathrm{T}_{\mathrm{TR}} \mathrm{S}\right.$ ) were defined. $\mathrm{T}_{\mathrm{TR}} \mathrm{S}$ demonstrated that the beginning temperature of thermally rearrangement was significantly dependent on the chemical structures of the precursor polymers which established that there is a linear relationship between $T_{T R} S$ with the glassy transition temperature $\left(\mathrm{T}_{\mathrm{g}}\right)$ of the precursor polymers. 
Based on the theory in Chapter 2, in Chapter 3, copolymerization with non-hydroxy diamines, so-called non-TR-able diamines, before thermal treatment was made to obtain thermally rearranged poly(benzoxazole-co-imide)s (TR-PBOIs). These poly(benzoxazole-coimide)s have much stronger mechanical properties than common TR-PBO and in this way, these materials overcome the mechanical issue of TR-PBO membranes. The relationships with polymer rigidity and gas transport properties were intensively studied and it was concluded that the main characteristics of TR-PBOIs were tuned by the ratio of non-TR-able diamines introduced in the polymer and that the right choice of chemical structures along with the enhancement of rigidity of precursor polymers improved the gas permeabilities while a higher flexibility led to a decrease of gas permeabilities but improved the ideal gas selectivities.

In Chapter 4, a new generation of TR-PBOs (spiroTR-PBOs) incorporating spirobisindane mioieties into the polymer structure are introduced. Precursor HPIs were prepared using a newly synthesized monomer, 3,3,3',3'-tetramethyl-1,1'-spirobisindane-5,5' dimaino-6,6'-diol as hydroxy diamine. SpiroTR-PBO highly improved the mechanical properties, mainly the elongation of membrane, due to the kink structure of spiro segment. Molecular simulation analysis of structure and property of spiroTR-PBO explains that the wide angle distributions present in the macromolecular structure makes to stain against applied out-forces. Moreover, the ladder structure of spiroTR-PBO introduced by the spirobisindane group as well as the kink moiety increases the polymer rigidity which then translates to improvements of the gas permeabilities due to the increase of the fractional free volumes. 
Chapter 5 studies a new research topic on crosslinking effect of TR copolymers. The monomer employed in this chapter is 1,3-diamino benzoic acid (DABA). This study has permitted to interpret the effect of cross-linking on TR polymers. Consequently, is has been demonstrated that DABA units undergo cross-linking by heat treatment acting as a role of pillars between polymer chains to sustain the polymer chain (increase of rigidity) and the free volume units. Crosslinking of TR copolymers results in about 4-fold and 25 fold increase in gas permeabilities compared with those of non-crosslinked TR-PBO copolymer and HPI precursor. Furthermore, incorporating cross-linking units in TR-PBO obviously generates synergetic effects with thermal rearrangement process not only by increasing gas permeability but also by augmenting the plasticization resistance.

Chapter 6 suggested the optimal crosslinked TR-PBO membranes with improved mechanical strength and gas permeabilities in the hollow fiber membrane form. The crosslinking effect on hollow fiber membranes were proved by measuring $\mathrm{CO} 2$ permeance of XTR-PBO hollow fiber membranes. In conclusion, the cross-linking between TR polymer chains maintained the effective skin layer and consequently helped to obtain high gas permeance. 


\section{$\underline{\text { Chapter } 1}$}

\section{Introduction: Recent High Performance Polymeric}

Membranes for Gas Separation - State of the Art 


\subsection{Introduction}

For recent decades, membrane technologies for gas separation have attracted a lot of attention, accompanied with worldwide demand and needs toward energy-efficient, ecofriendly, and sustainable technologies as competitive as cryogenic distillation and pressure swing absorption (PSA) which require high energy by phase changes [1, 2]. Thus, and as an example, the process intensification and small space systems make membrane technology to be more attractive especially for applications at remote location [1, 3]. Since the first gas separation membranes using polysulfone or cellulose acetate membrane were implemented for $\mathrm{H}_{2}$ separation in ammonia purge gas in 1980, membrane markets have enlarged and extended to nitrogen enrichment from air, natural gas production, and refinery gas purification and a large number of applications. The current urgency of greenhouse gas reduction and other gas separation applications such as $\mathrm{CO}_{2}$ separation from flue gases emitted from power plants (post-combustion), $\mathrm{CO}_{2}$ removal from Integrated Gasification Combined Cycle (IGCC) process (pre-combustion), and $\mathrm{CH}_{4}$ concentrating from biogases have emerged in the last years. Gas separation technologies using membranes have been developed and are growing gradually; moreover, a rapid market growth is expected in the near future [4].

Among the materials employed for gas separation membranes, polymeric membranes have been dominant in industry because of relative preparation conveniences and cost efficiencies. For instance, polysulfones (PS), polyimides (PI), and cellulose acetates (CA) are representative commercialized materials. However, acidic gases such as $\mathrm{CO}_{2}, \mathrm{CH}_{4}$ and $\mathrm{H}_{2} \mathrm{~S}$ causes a swelling in polymer chains and thus membranes are losing separation efficiency by increasing of the free volume. This phenomenon is more significant under high feed pressure; thus, this fact 
limits the application range of polymeric membranes. Furthermore, permeability drop by physical aging of glassy polymers is another issue, because the free volume of polymer in nonequilibrium state gradually decreased until reaching thermodynamic equilibrium. Low permeability of commercialized polymers also asks for the tremendous scales of modules as well as costs, which limits its use in industrial $\mathrm{CO}_{2}$ capture technology. As permeability of membranes is related with economic values, high permeable membranes with high selectivity are the most prior tasks for membrane developments. Unfortunately, catching the both properties are not pieces of cakes because the permeation of gases through polymer membranes by solution-diffusion mechanism derive in the existence of strong trade-off relationships between permeability and selectivity of gas pairs, which means that the improving permeability of polymer is followed by reducing permselectivity [5]. Nevertheless, several novel polymers have recently emerged that have overcome the permeability-selectivity trade-off limitation. Developments of high performance polymers make membrane technology to be more challengeable not only for gas separation also for other separation technologies. More details of novel polymers such as polymer with intrinsic microporosity (PIM), thermally rearranged (TR) polymers, carbon molecular sieve (CMS), and high-performance polyimides will be introduced in the following section.

In this thesis, Thermally Rearranged (TR) polymers were mainly considered. These materials are high permeable and selective ones by having tuned bimodal cavities [6]. Diverse TR polymer designs have been newly suggested and developed to solve the implemental limitations as well as to improve gas transport properties by applying chemical modifications into polymers or membranes such as; copolymerization[7-11], cross-linking[12, 13] and so on. 
It is significantly discussed in the bibliography the search of relationships between chemical structural with physical properties and small gas transport properties. Moreover, main effects of modifications on gas transport phenomenon have been precisely considered.

\subsection{Backgrounds and terminologies}

Membranes are commonly classified according to its structure (dense, symmetric, asymmetric, thin-film composites) as shown in Figure 1-1 and the permeation mechanisms (Knudsen diffusion, molecular sieve, and solution-diffusion) as shown in Figure 1-2. Asymmetric membranes are composed of an effective skin layer and a thick support layer. Most of membrane modules are in the forms of asymmetric membranes. The thickness of effective skin layer uses to be unknown; and hence sometimes the study using symmetric membranes is required. Membrane thickness decides the gas permeation flux; therefore, the formation of thin skin layers (less than $1 \mu \mathrm{m}$ ) is important to obtain high permeable membranes. Thin-film composite is required to save the material cost.

Separation using membranes is a process of filtering and concentrating a desired component from mixture. A typical schematic diagram of gas separation using membrane is shown in Figure 1-3. Gas permeability (P) is defined by the flux (J) across the membrane thickness (l), given the pressure gap $(\Delta \mathrm{p})$ between upstream and downstream as shown blow equation.

$$
\mathrm{P}=\frac{J \times l}{\Delta p}
$$


When $\Delta \mathrm{p}$ is given between the upstream (input) and the downstream (output) as a driving force, the feed gas mixture pass through the membrane. The gas across the membrane is called permeate at the lower pressure side and the remained gas is called retentate. Depending on the application and required gas purity, the product could be permeate or retentate. The efficiency of gas separation is influenced not only by pressure gap but the formation of adequate pore size and narrow pore distributions are mandatory. Therefore, it is important to select the suitable membranes according to the employed feed mixture to obtain a valuable product.

Generally three types of gas transport mechanisms have been suggested depending on pore size as depicted in Figure 1-2. In Knudsen process, the molecules passing through the membrane have a smaller diameter than the distance of path of a molecule. In this diffusion process, the relative permeation rate is given by the inverse square root of the molecular weight of the gases [14]. The separation by Knudsen diffusion provides much lower selectivity than by molecular sieve and solution-diffusion. Molecular sieving membranes are ultramicroporous materials, having pore diameters bigger than $7 \AA$ and smaller size gases transport is much faster than for larger gases. Carbon membranes are representative of this type of process. Still, the fragility inherent to these membranes has prevented their commercialization, even though they show superior gas permeability. On the other hand, the solution-diffusion process is observed mostly in nonporous (dense) polymeric membranes. This diffusion process results in higher selectivity of gas pair. Solution-diffusion mechanism considers not only the pore size but also the interaction between polymer membranes and gases in the process of adsorbing onto the surface, diffusing through the body of material, and desorbing out from the opposite side of surface. The gases are not continuously diffused in the body; however, the 
molecules jump among polymeric free volume elements by Brownian motion [4, 15, 16]. The gases can jump from upstream to downstream when high concentration is given in the upstream. Therefore, the controlling sized and distribution of free volume (cavities) is directly related with the diffusivity selectivity of gases pairs.

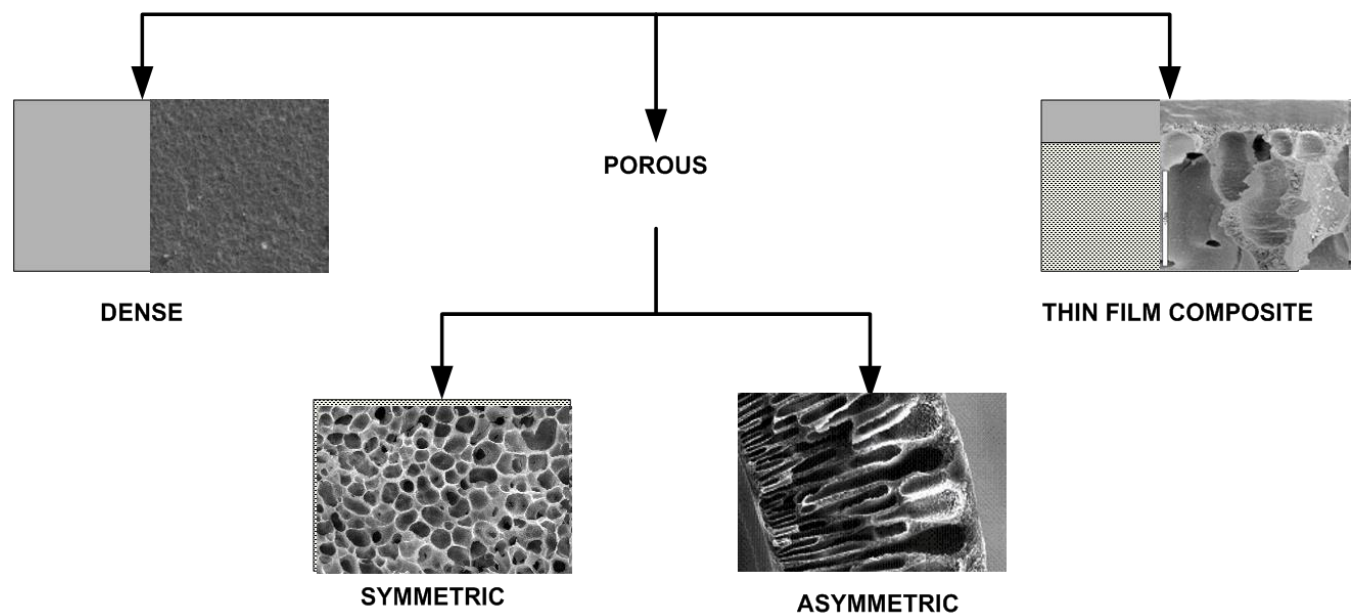

Figure 1-1 The structural classification of membranes.

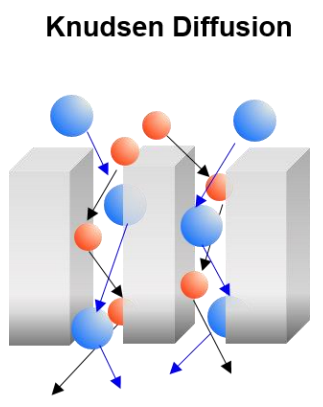

(A)

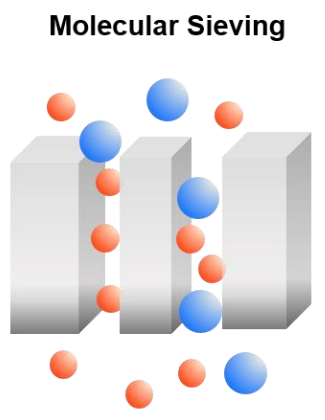

(B)

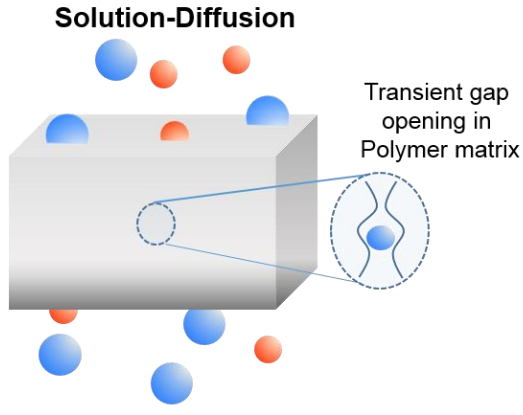

(C)

Figure 1-2 Types of membrane transport phenomena. 


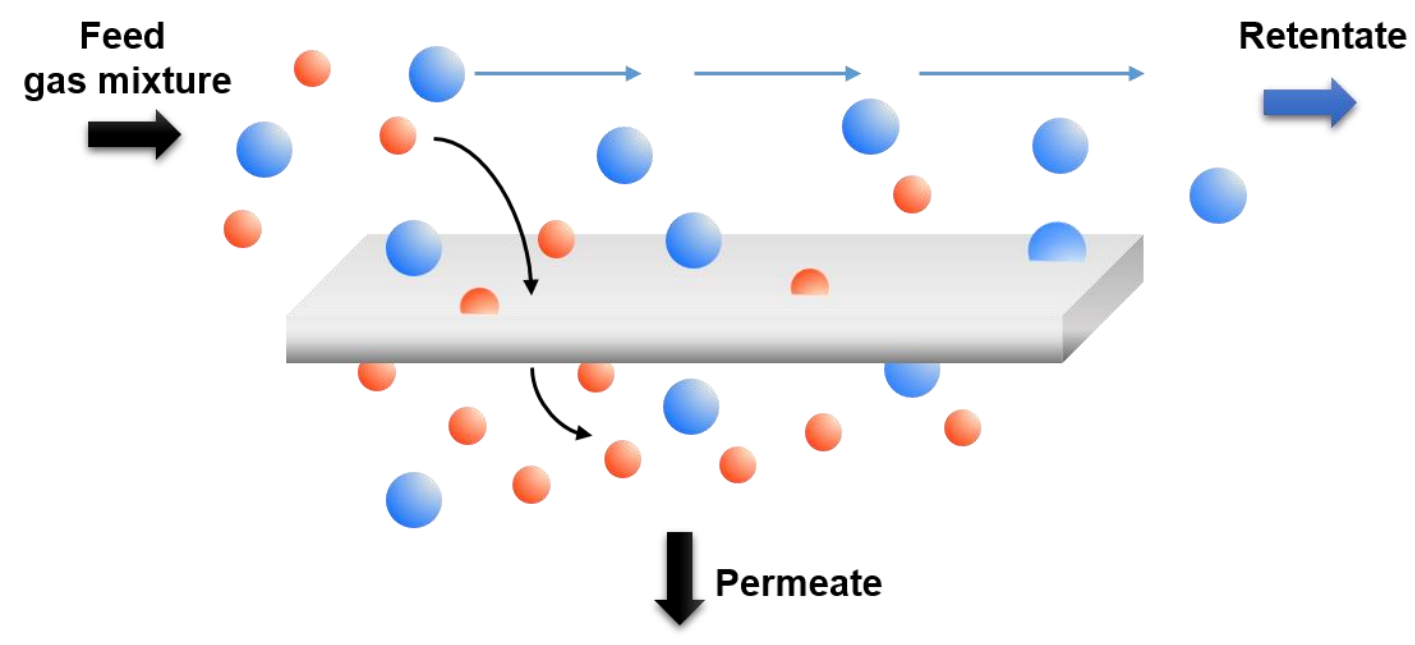

Figure 1-3 General gas separation phenomenon when feed gas mixture is passing through a membrane.

Gas permeability or permeability coefficient (P) by the solution-diffusion model is presented by two terms; the diffusivity coefficient (D) as a kinetic term, describing mobility of gas molecule passing through the membrane and the solubility coefficient (S) as a thermodynamic term, describing the amount of the gas molecules sorbed into the membrane as shown in Equation (1-2).

$$
\mathrm{P}=\mathrm{D} \times \mathrm{S}
$$

In here, gas permeability is the flux normalized by pressure and thickness as a constant intrinsic parameter, which is simply measured by permeation experiments. Single gas permeability of symmetric membrane is commonly measured by time-lag experiments, considering steadily increased pressure rate in the downstream volume chamber under the constant feed pressure and temperature. Time-lag method is worthy to figure out the diffusivity 
coefficient at the ideal system and solubility coefficient is estimated by measured P and D as shown in Equation (1-3) and Equation (1-4), respectively. The unit of permeability is Barrer and it is based on the standard temperature and pressure (STP) condition (1 Barrer $=10^{-10}$ $\left.\mathrm{cm}^{3}(\mathrm{STP}) \cdot \mathrm{cm} / \mathrm{cm}^{2} \cdot \mathrm{s} \cdot \mathrm{cmHg}\right)$.

$$
\begin{gathered}
\mathrm{P}=\frac{V(S T P) \cdot l}{\Delta p \cdot A \cdot R \cdot T} \\
D=\frac{l^{2}}{6 \theta}
\end{gathered}
$$

When $\mathrm{P}$ is gas permeability, $\mathrm{V}$ is the volume rate, $\mathrm{A}$ represents the effective area of membrane, $\mathrm{R}$ is the ideal gas constant, and $\mathrm{T}$ is the temperature. Diffusivity, $\theta$, is the time-lag determined from constant volume measurements. However, estimated solubility coefficient by time-lag is not accurate for gases having low solubility value such as $\mathrm{He}$ and $\mathrm{H}_{2}$, mainly due to the high diffusivity of these gases in many polymeric materials, which brings about a high experimental error on the value of $\mathrm{D}$ and consequently of S.

In order to determine solubility coefficients more accurately, the barometric pressure decay method has been used under constant pressure and temperature [6]. The solubility coefficient is the ratio of the concentration of gas sorbed $(C)$ divided by the driven pressure $(p)$ as shown in Equation (1-5). The four different types of sorption behaviors typically observed are shown in Figure 1-4. Figure 1-4(a) depicts the sorption isotherm following only Henry's law that linearly increased according to increasing pressures when light gases are sorbed in rubbery polymers. For more condensable gases such as $\mathrm{CO}_{2}$, hydrocarbons and vapors, the sorption behavior does not obey the Henry's raw by showing non-linear relationship under sufficiently 
high pressures. Figure 1-4(b) describes the Flory-Huggins model, observed when, for instance, acetone is sorbed in cross-linked poly(dimethyl siloxane) (PDMS). The dual mode sorption behavior for glassy polymers is shown in Figure 1-4(c) that obeys Henry's law and Langmuir isotherm behavior. Langmuir isotherm reflects the gas sorption in the free volume excess inside polymer chains at temperature below glass transition temperature $\left(\mathrm{T}_{\mathrm{g}}\right)$. Equation (1-6) denotes the gas concentration sorbed in a materials following dual mode sorption, which is the sum of two terms; Henry's law $\left(C_{D}\right)$ and Langmuir isotherm $\left(C_{H}\right)$ with Henry's law coefficient $\left(k_{D}\right)$, Langmuir capacity constant $\left(C_{H}^{\prime}\right)$ and the affinity constant $(b)$.

$$
\begin{gathered}
\mathrm{S}=\frac{C}{p} \\
\mathrm{C}=C_{D}+C_{H}=k_{D} p+\frac{C_{H}^{\prime} b p}{1+b p}
\end{gathered}
$$

Under low and moderate pressure condition, the gas sorption in glassy polymer is dominated by Langmuir term. $C_{H}^{\prime}$ is dependent on temperature and $\mathrm{T}_{\mathrm{g}}$. Increment of $\mathrm{T}_{\mathrm{g}}$ leads to increasing the excess of free volume at the specific temperature below $T_{g}$, and consequently $C_{H}^{\prime}$ value is increased. On the other hand, the $C_{H}^{\prime}$ value decreases as increasing the size of molecules due to the much smaller fraction to occupy the free volume. Figure 1-4(d) is the sigmoidal-shaped sorption isotherm, which can be observed in highly-concentrated gases sorbed in the material and in plasticized membranes. This behavior is estimated by dual mode sorption of the Flory-Huggins model with Langmuir isotherm. 

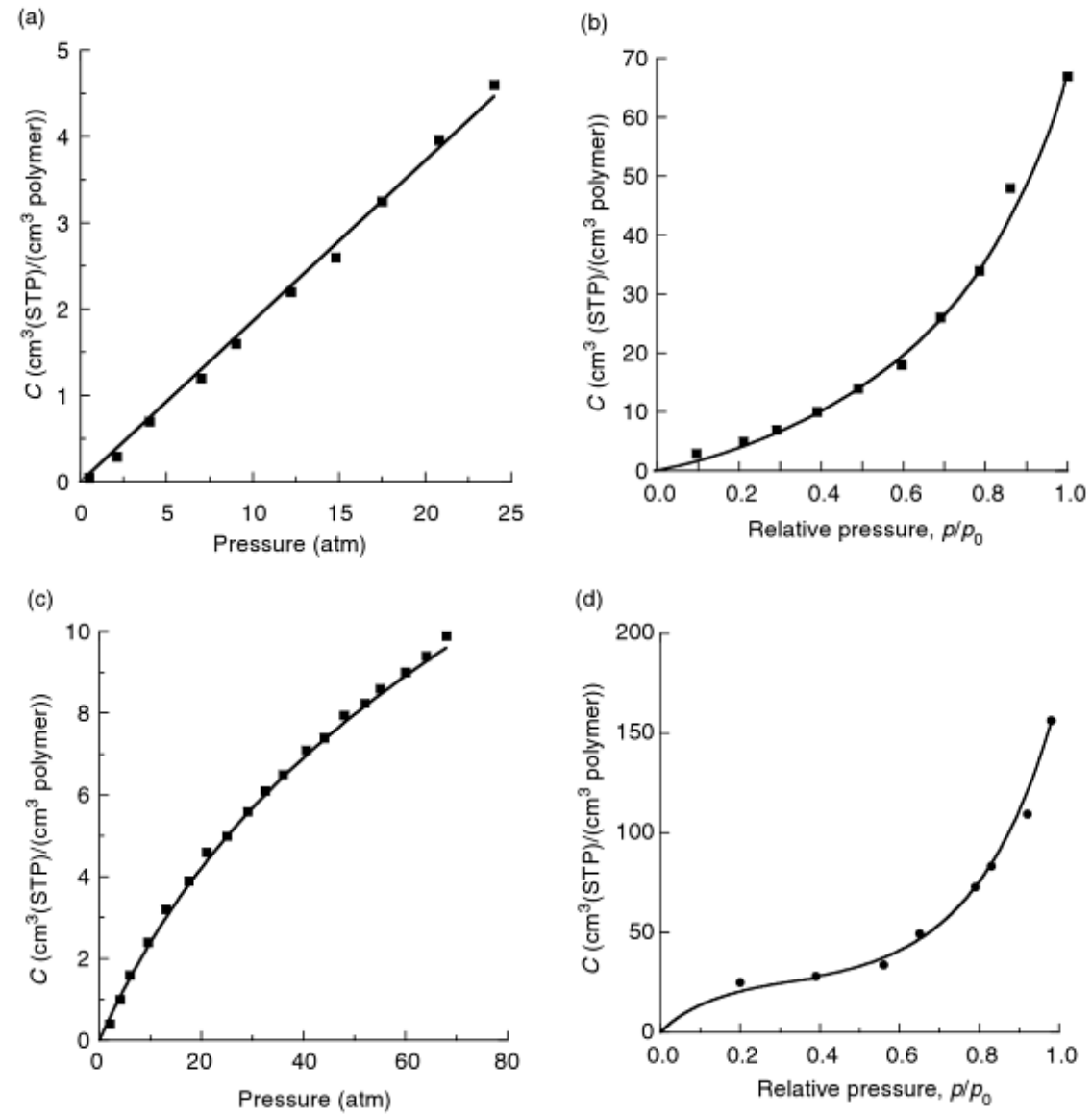

Figure 1-4 Typical gas sorption isotherms: (a) Henry's law, (b) Flory-Huggins, (c) dual mode sorption, (d) sigmoidal shaped sorption. [17] 
Ideal gas selectivity $(\alpha)$ is simply determined by the ratio of permeability of gas A and B, measured from single gas experiments as shown in Equation (1-7). Each ratio of diffusivity and solubility coefficient indicates diffusivity selectivity $\left(\alpha^{D}\right)$ and solubility selectivity $\left(\alpha^{\mathrm{S}}\right)$, which is useful to rationalize gas transport properties of polymers.

$$
\alpha_{A B}=\frac{P_{A}}{P_{B}}=\frac{D_{A}}{D_{B}} \cdot \frac{S_{A}}{S_{B}}=\alpha_{A B}^{D} \cdot \alpha_{A B}^{S}
$$

But in mixed gas system, mixed gas selectivity is influenced by the mole fraction of feed gas mixture and it is defined as the ratio of the permeate gas composition divided by the feed gas composition, as it is depicted by Equation (1-8). Mixed gas permeation test results are much representative for real-world gas separation processes.

$$
\alpha_{A B}^{\#}=\frac{N_{A} / N_{B}}{x_{A} / x_{B}}
$$

Permeation of nonporous polymer membranes is taking place in such a way that penetrates passes through free volumes (cavities) (Fig. 4). The size and amount of free volume elements are significantly related to diffusivity for polymer membranes as predicted by Equation (1-9) [18], indicating that the diffusivity increases as free volume increases, where FFV is fractional free volume, A is a geometric factor, $v^{*}$ is a factor of gas molecule size and $\gamma$ is an overlap factor of the free volume elements.

$$
\mathrm{D}=\mathrm{A} \exp \left(-\frac{\gamma v^{*}}{F F V}\right)
$$

FFV can be calculated by the differences between the specific volume (V) and the theoretical volume $\left(\mathrm{V}_{0}\right)$ of polymer chains. Theoretical occupied polymer volume is estimated 
using Bondi's group contribution theory, expressing the sum of van der Waal's volume of each segments of a polymer. The specific volume is obtained by real estimation of polymer density. The development of positron annihilation lifetime spectroscopy (PALS), has permitted to calculate FFV determining the free volume size elements and also it permits to calculate the FFV distribution in the membrane.

Strong interaction between polymer and gas molecules influences the polymer chain mobility, and consequently the gas permeability and selectivity. The permeability is decreased as increasing pressure due to volume relaxation and gradual saturation of microvoids in glassy polymers [19]. As increasing pressure, sudden elevation of permeability indicates that the gases are sorbed strongly, and thus the polymer swells. This process is called plasticization. Plasticization of membrane results not only in increasing permeability but also in decreasing gas selectivity. This phenomenon is much stronger for acid gases or hydrocarbons, which are highly sorbed in polymer membrane. In order to design gas separation materials for acid gas separation at harsh environmental applications, the suppression of plasticization is required for polymer membranes.

Polymers in non-equilibrium state possess excess free volume elements, which lessen as time goes by small movement of the polymer chains in order to reach a lower-energy equilibrium state. This phenomenon is called physical aging and causes losing permeability as compare with that one of initial state of the membrane. Highly porous membranes such as rubbery polymer or microporous polymer membranes have shown dramatic drops in permeability after passing just a few days. Also, this physical aging phenomenon is significantly related with film thickness, exposure time and pressure [20]. Physical aging of 
polymer membranes would preclude the implementation on industrial applications. On the other hand, thermally aged polymers resist the aging coming further.

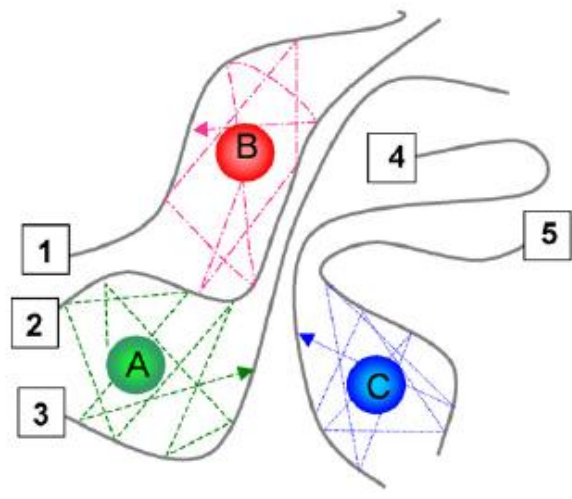

Position of molecules at one instant

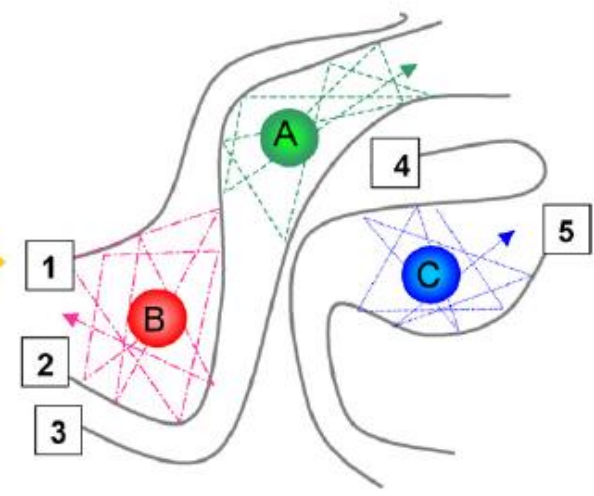

Position of molecules at the next instant

Figure 1-5 Motion of gas molecules within the cavities through a series of diffusional jumps. [21]

\subsection{Applications using polymer membranes}

Polymer membranes and modules have been commercialized for several feed stream treatments (Table 1-1). Especially, it is more employed for the treatment of small gas streams that other membrane technology because it is much economically suitable and efficient than any other separation technology. Initially, polymeric membranes could be applied for hydrogen recovery from ammonia purge gas stream due to the high permeable and selective behavior of this gas respect to other gases such as nitrogen or carbon dioxide. Monsanto was the first in making hydrogen recovery using PRISM ${ }^{\circledR}$ hollow fiber membranes based on polysulfone in 1979. This technology now achieves 95\% hydrogen recovery by using recycling systems. Refinery of gas purification, separating hydrogen from methane generated from hydrocracking 
of petroleum crude and syngas ratio adjustment, separating hydrogen from carbon monoxide are also currently membrane-commercialized fields [4].

The largest market using membrane is nitrogen enrichment from air. Up to 99.9\% nitrogen can be produced using polymer membranes having a selectivity of $6 \sim 7$. Thus, when the nitrogen is feeding in the rate from $6 \sim 1200 \mathrm{~m}^{3} / \mathrm{h}$ and the industry is asking for purity of $95 \sim 99 \%$, membrane technology is more economical than pressure swing adsorption (PSA) [4]. Interestingly, On-Board Inert Gas Generation System (OBIGGS) has arisen as a nitrogen separation technology for the fuel tank blanketing of planes in order to prevent the explosion riskiness from the flammable air/fuel mixture in the aircraft and this technology has become one of the major markets of membranes in the industry. On the other hand, producing highpurity oxygen is much difficult than obtaining high-purity nitrogen by one-stage membrane system. In this way, only 68\% oxygen can be produced under the zero stage-cut and infinite pressure ratio when the membrane selectivity is 8 at one-stage process. General and beneficial range of oxygen concentration produced by membrane system is $30 \sim 50 \%$ and most of them is applied for the combustion process, for instance, the treatment of exhaust gas. Besides, use of oxygen-enriched gas is efficient to diesel engines as well as cost-effective [4]. These drawbacks have turned out the academy and industry to develop useful technology for carbon dioxide capture from combustion process that should debut to real markets in near future.

Natural gas processing is an immerse market of gas separation in United States which produces $20 \%$ natural gas worldwide. Natural gas contains various hydrocarbons and acid gases under high-pressure conditions. In order to reduce the gas volume and increase the energy potential, $\mathrm{CO}_{2}$ has to be removed from natural gas in the gas sweetening process [22]. However, 
the designed polymer membrane should have negligible $\mathrm{CO}_{2}$-induced plasticization as well as high selectivity in order to be applied. Presently, only 5\% of membrane market share is occupied by membrane technology in this field [4]. Improving and developing new membrane technology and new materials, should increment the market share rate. This improvement would be useful not only for producing high-quality natural gas but also for capturing greenhouse gases; mainly $\mathrm{CO}_{2}$ although the no emission of methane to the atmosphere is getting much more important nowadays due to its influence in global warming. In addition, this gas should not be emitted from waste food and garbage [23].

Most expectable near-future markets of gas separation are carbon dioxide capture (CCS) technologies. Greenhouse gases (GHG) such a $\mathrm{CO}_{2}$ and $\mathrm{CH}_{4}$ influence the climate and the global warming increasing the temperature of the Earth. Since DOE and IPA report the CO2 concentration atmosphere as 385ppm in the end of 2009, it is hitting the 400ppm line in 2015 by following the Business as Usual (BAU). Still GHG reduction is the biggest project in the world, and global efforts are being much pushed, asking for effective and realistic technologies that result in substantial changes. The membrane technologies are one of the most challengeable and applicable to CCS [24]. Mainly three processes have been suggested for $\mathrm{CO}_{2}$ capture from fossil-fuel-based large-scale power generation sites as shown in Figure 1-5 with descriptions of each process. MTR, a US company, practically is using polymer membrane modules (Prism) in pre-combustion process of IGCC plant and flue gas separation of power generation plants $[25,26]$. 
Table 1-1 Commercialized separation processes and membranes [19].

\begin{tabular}{|c|c|c|c|}
\hline Separation & $\begin{array}{l}\text { Principal } \\
\text { producers }\end{array}$ & Membrane & $\begin{array}{c}\text { Market size. } \\
\text { (US\$ million/year) }\end{array}$ \\
\hline $\begin{array}{l}\text { Nitrogen from air } \\
\text { Water from air }\end{array}$ & $\begin{array}{c}\text { Permea } \\
\text { Medal } \\
\text { Dow, Geberon } \\
\text { Ube } \\
\text { Aquilo } \\
\end{array}$ & $\begin{array}{c}\text { Polysulfone } \\
\text { Polyimide } \\
\text { Polyimide } \\
\text { Polyimide } \\
\text { Polyphenylene oxide } \\
\end{array}$ & 150 \\
\hline $\begin{array}{l}\text { Carbon dioxide from natural } \\
\text { gas }\end{array}$ & $\begin{array}{c}\text { Cynara } \\
\text { Medal } \\
\text { Grace, Separex } \\
\text { MTR } \\
\end{array}$ & $\begin{array}{c}\text { Cellulose triacetate } \\
\text { Polyaramide } \\
\text { Cellulose acetate } \\
\text { Perfluoro polymers } \\
\end{array}$ & 100 \\
\hline $\begin{array}{c}\text { Refining: } \mathrm{H}_{2} / \mathrm{CH}_{4} \\
\text { Ammonia plants: } \mathrm{H}_{2} / \mathrm{N}_{2}, \mathrm{Ar} \\
\text { Syngas : } \mathrm{H}_{2} / \mathrm{CO}\end{array}$ & $\begin{array}{c}\text { Permea } \\
\text { Medal } \\
\text { MTR/ Ube }\end{array}$ & $\begin{array}{c}\text { Polysulfone } \\
\text { Polyaramide } \\
\text { Polyimide }\end{array}$ & 75 \\
\hline C3+ Hydrocarbons/ Nitrogen & $\begin{array}{l}\text { MTR } \\
\text { Borsig }\end{array}$ & $\begin{array}{l}\text { Silicon rubber } \\
\text { Silicon rubber }\end{array}$ & 30 \\
\hline $\begin{array}{l}\mathrm{N}_{2}, \mathrm{He}, \mathrm{H}_{2} \mathrm{~S} \text { from natural gas } \\
\mathrm{CO}_{2} / \mathrm{H}_{2} \text {. Miscellaneous petro- } \\
\text { chemicals }\end{array}$ & - & Many polymers & 20 \\
\hline
\end{tabular}

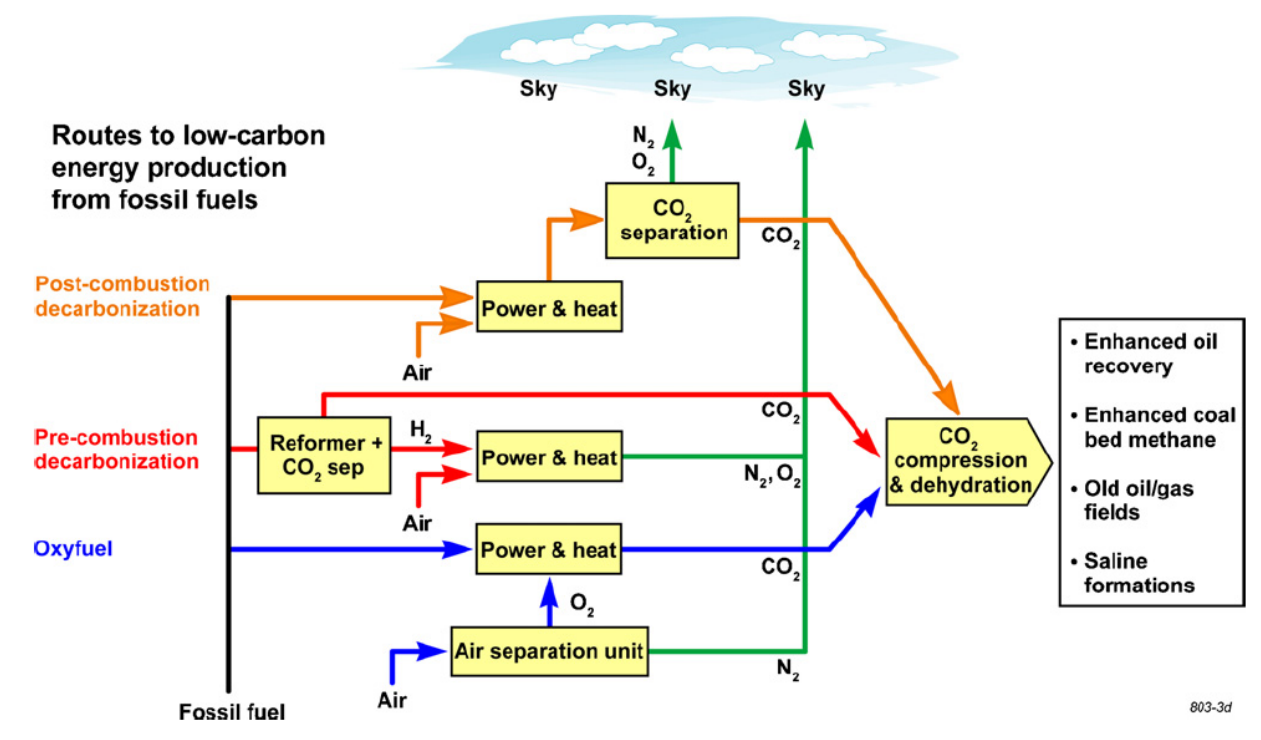

Figure 1-6 Applicable $\mathrm{CO}_{2}$ separation technologies and process in fossil-fuel based power plants for carbon capture and storage (CCS) [25]. 
Table 1-2 Main carbon capture processes using membranes.

\begin{tabular}{|l|l|l|}
\hline & $\begin{array}{l}\text { Separating } \\
\text { main gases }\end{array}$ & Descriptions \\
\hline $\begin{array}{l}\text { Post-combustion } \\
\text { process }\end{array}$ & $\mathrm{CO}_{2} / \mathrm{N}_{2}$ & $\begin{array}{l}\text { Flue gases exhausting from combustion } \\
\mathrm{CO} \text { concentration } \sim 30 \% \text {, balanced with } \mathrm{N}_{2} \\
\text { Ambient temperature }\left(\sim 60^{\circ} \mathrm{C}\right) \text { and pressure }(\sim 1 \mathrm{~atm}) \\
\text { Humidified (water vapor included) }\end{array}$ \\
\hline $\begin{array}{l}\text { Pre-combustion } \\
\text { process }\end{array}$ & $\mathrm{H}_{2} / \mathrm{CO}_{2}$ & $\begin{array}{l}\text { Separating } \mathrm{CO}_{2} \text { from water gas shift (WGS) reaction to } \\
\text { produce } \mathrm{H}_{2} \text { used for syngas. } \\
\text { High temperature }\left(>200^{\circ} \mathrm{C}\right)\end{array}$ \\
\hline $\begin{array}{l}\text { Oxy-fuel combustion } \\
\text { process }\end{array}$ & $\mathrm{O}_{2} / \mathrm{N}_{2}$ & $\begin{array}{l}\mathrm{O}_{2} \text { enrichment from air to improve combustion-efficiency } \\
\text { before input into boiler }\end{array}$ \\
\hline
\end{tabular}

\subsection{Emerging high-permeable polymer membranes}

Achieving higher permeability in polymer membranes means to counterbalance with the decrease in permselectivity determined by the well-known permeability-selectivity trade-off relationship. Robeson suggested the plots of permeability versus permselectivity of gas pairs and the boundary line, which obtained by collecting many literature data of polymeric membranes. This boundary line is so-called 1991 Robeson upper bound [5]. Later, using data generated from his primary work to the time he made a revision, Robeson determined a second boundary line; 2008 Robeson upper-bound [5, 27]. The empirical upper bound between the permeability and permselectivity clearly determines the limitations of polymer membranes. These Robeson plots serve to compare the performances among membranes and thus, it is a useful tool in the gas separation industry. However, Robeson's analysis uses only pure gas information which defines the main limitation of these plots. Because of difficulties of practical application due to the differences of the gas transport properties between pure and mixed gas, recently the $\mathrm{CO}_{2} / \mathrm{CH}_{4}$ upper bound was revisited by applying a modified free volume theory [28]. In order to surpass the 1991 and 2008 upper bounds, several novel polymer materials 
have been developed by combining high chain rigidity and stiffness of the macromolecular chain along with the attachment of bulky groups or by including very contorted structures [29, 30]. The representative examples of high-performance polymers are shown in Figure 1-6. $\mathrm{CO}_{2}$ permeability with $\mathrm{CO}_{2} / \mathrm{CH}_{4}$ selectivity collections of representative polymer materials close or beyond the 2008 upper bound have been developed in the last 5 years which has inspired the possibility of expanding gas separation applications requiring high gas permeability and moderate or high selectivity (Figure 1-7), for instance, polymers with intrinsic microporosity (PIM), Troger based intrinsic microporosity, novel polyimides (PI), carbon molecule sieves (CMS) from polyimides, and TR polymers.

PIMs have shown incredible permeability by having rigid and ladder main backbones, possessing in addition adequate microporous cavities. Since the high permeability of the first PIM-1 was discovered (Figure 1-6 (a)) in 2004 [31-33], various PIMs have been developed to suppress $\mathrm{CO}_{2}$ plasticization and physical aging of inherent PIM-1 [34-37]. In 2013, Troger based intrinsic microporosity was suggested to improve their own rigidity and resulted in higher permeabilities (Figure 1-6 (b) and (c)) [38]. Moreover, PIMs incorporating various cross-linking method have been obtained, which has improved their gas selectivities [39-42].

Newly and well-optimized polyimides are located over 1991 upper bound which is the main limitation of prior polyimides by attaching bulky and rigid groups in polymer backbone such as the triptycene group (Figure 1-6 (d)), the spirobisindane groups and so on. Triptycene based PIM-PI obtained showed permeabilities more than 4000 Barrer to $\mathrm{CO}_{2}$ with values of 22 of $\mathrm{CO}_{2} / \mathrm{CH}_{4}$ selectivity that is above the 2008 upper bound line. This polyimide has lots of manufacture advantages, and thus the development of high-performance polyimides will be 
keep going on [43-48].

Chemically or thermally induced cross-linking based on 3,5-diamino benzoic acid (DABA) have shown enhancement of permeability and low plasticization in polyimides. Other way of decrease the plasticization has consisted of making thermally induced cross-linking processes at temperature lower than $400^{\circ} \mathrm{C}$, in which the polyimide backbone survived. On the other hand, carbon molecular sieve membrane could be obtained by applying much higher temperature in the range of $400 \sim 600{ }^{\circ} \mathrm{C}$. CMS based on cross-linked polyimide showed incredible high gas selectivity, which was much higher than those showed by cross-linked PIMs and TR polymers [49-51]. CMSs based on polyimides are beneficial to produce membranes as hollow fibers, but its fragility is still an issue to be solved.

High performance TR polymers have studied for upgrading their mechanical weakness to be implementable materials for last decades as well as for expanding their application. In order to improve physical and mechanical properties, various technical methods have been introduced into the polymer backbone such as combination with PIM and cross-linking to improve permeabilities [12, 13, 52-56]. More details in TR polymers in gas separation membranes will be explained in the next section. 


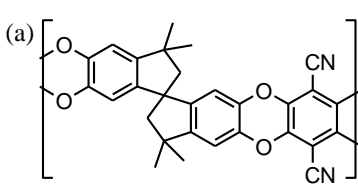

PIM-1

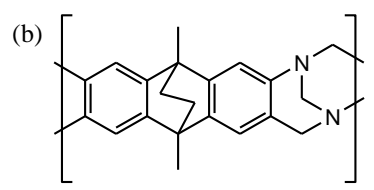

PIM-EA-TB

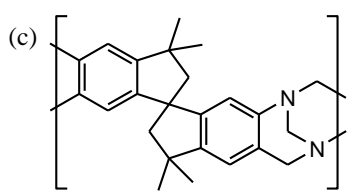

PIM-SBI-TB

(d)

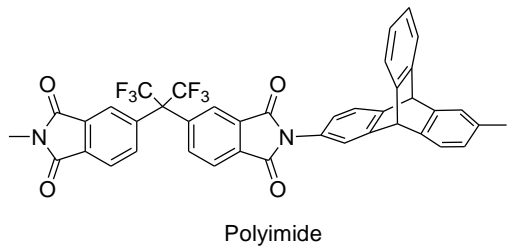

(e)
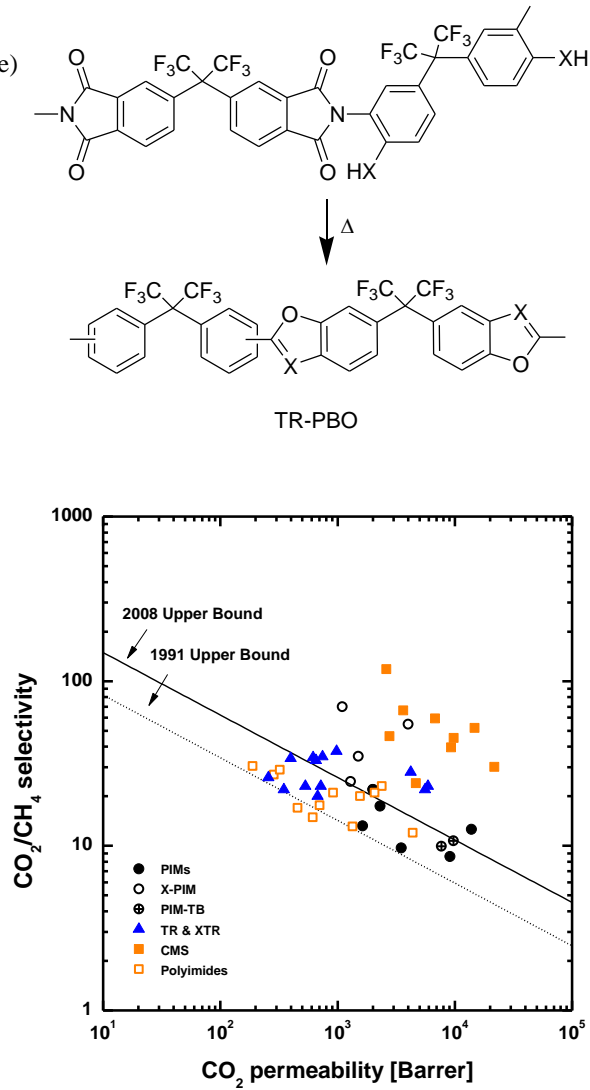

(f)

Figure 1-7 Chemical strucrues of emerged high-performance polymers for gas separation (a) polymer with intrinsic microporosity (PIM-1), (b) PIM-EA-TB, (d) PIM-SBI-TB, (d) polyimide with triptycene structures, (e) thermally rearranged polybenzoxazole (TR-PBO) and (f) $\mathrm{CO} 2$ permeability with $\mathrm{CO} 2 / \mathrm{CH} 4$ plot of recently emerged polymer membranes comparisons with Robeson upper bounds. 


\subsection{Thermally rearranged (TR) polymers}

Thermal conversion in solid state from hydroxy-containing fully aromatic polyimide (HPI) to polybenzoxazole (PBO) was firstly introduced by Tullos and Mathias in 1999 [57, 58]. They found that a certain percentage of carbon dioxide was lost and benzoxazole groups emerged while hydroxyl groups and imide groups disappeared during heating up between $350^{\circ} \mathrm{C}$ and $500^{\circ} \mathrm{C}$ under nitrogen atmosphere or vacuum. Proposed hetero-cyclization is shown in Scheme 1-1. The properties of thermally converted polybenzoxazole in film state were investigated and resulted in superior thermal and chemical stability. Consequently, the hetero-cyclization was considered as a plausible method for preparing high performance polybenzoxazoles[59]. The singular characteristics of thermally rearranged polybenzoxazoles (TR-PBO) in gas separation membranes were discovered in 2007 by Park et al[6]. When HPI was heated up and converted to PBO, the size of cavities and the free volume within polymer networks were increased, showing narrow and bimodal cavity distributions (Figure 1-8(a) and (b). The rearrangement in polymer chains during thermal conversion formed hourglass shaped cavities in the range of

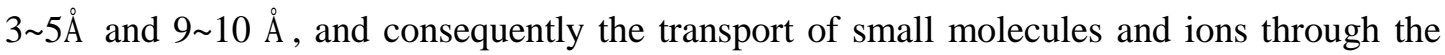
material significantly enhanced. TR-PBOs clearly overcame the past 1991 upper bound line as shown in Figure 1-8(c), and it contributed to revise the 2008 upper bound line. Gas permeability of thermally rearranged (TR) polymer membranes is almost a hundred times higher than precursor polyimide membranes, showing similar behavior to microporous polymers as PTMSP, which possesses ultrahigh free volume and high $\mathrm{CO}_{2}$ permeability. Increment rigidity (and plausible cross-linking processes due to the high temperatures employed) by thermal rearrangement to $\mathrm{PBO}$ can explain the remarkable high plasticization resistance of these 
materials to condensable gases. Process feasibility and physical-chemical stability of TR polymer membranes induced to consider that these materials could be implemented for the industry in gas separation $[6,60,61]$. The applications of TR polymers is not only useful for gas separation (GS) but that it can widening be applied also to pervaporation (PV) [62], electrolytes for fuel cell (FC)[63] separators for Li-ion batteries [64], organic solvent nanofiltration (OSN), membrane distillation (MD) and other applications due to their high thermal and chemical strength and their outstanding ability to separate mixtures.

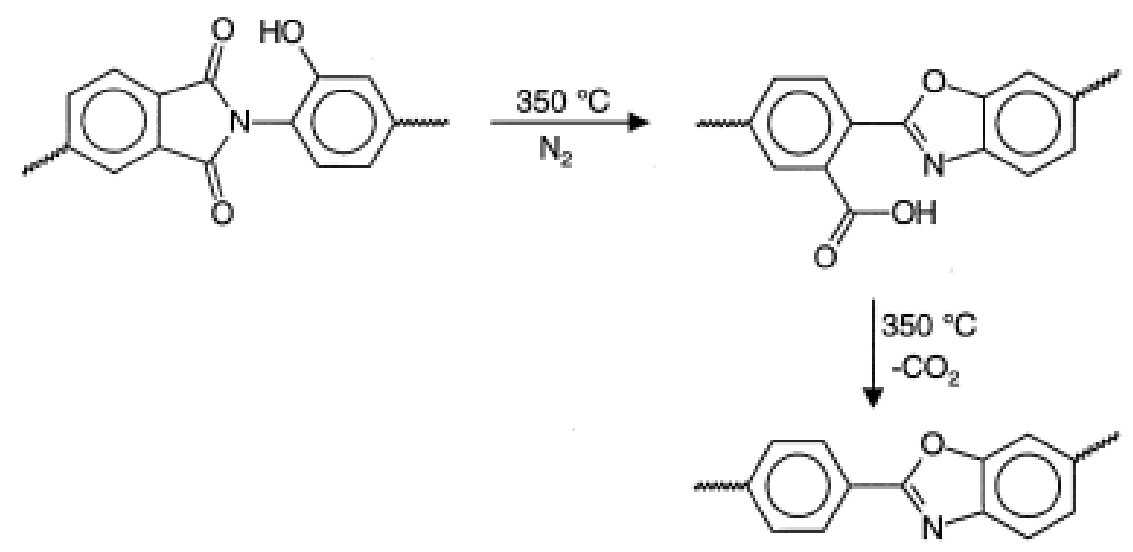

Scheme 1-1 Proposed reaction for thermal conversion of hydroxy-imide to benzoxazole [58]. 

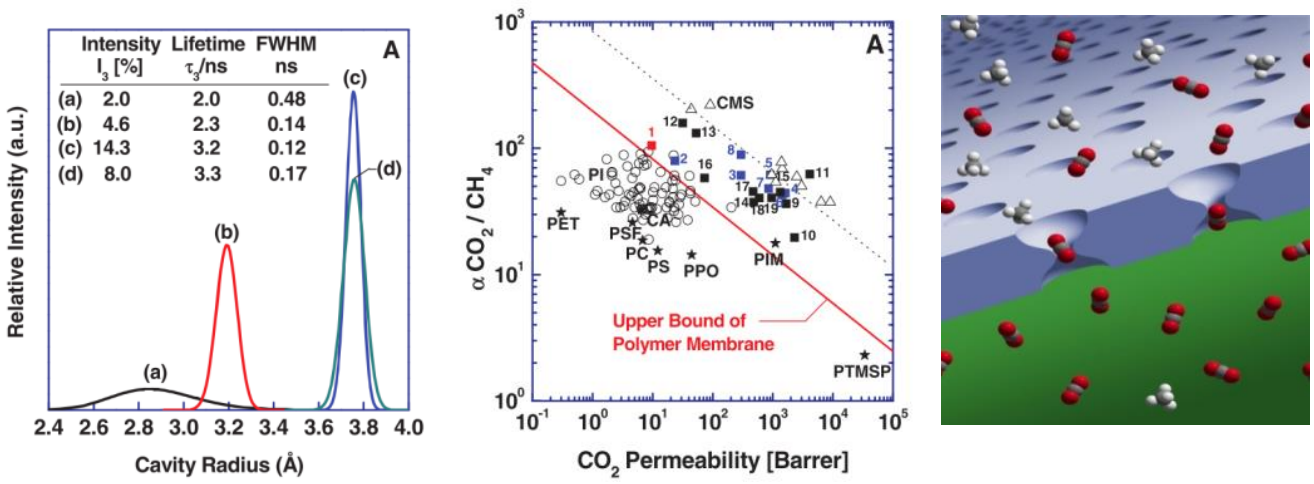

Figure 1-8 Change in cavity radius distribution as increases in temperature (a) TR-1-300, (b) TR-1-350, (c) TR-1-400, and (d) TR-1-450 measured by PALS (left), $\mathrm{CO}_{2}$ permeabilities with $\mathrm{CO}_{2} / \mathrm{CH}_{4}$ selectivity relationship of TR-polymer in blue (center), and the description of the gas transport through bimodal cavities of the TR-polymer membrane (right) [6]

TR polymers have attracted the attention of many researchers because physical and gas transport properties of these polymers are tunable according to the treatment conditions (temperatures, time, and gas employed in the thermal treatment)[56, 65-68], to the chemical structures of precursor polymers[69] , and to the synthesis protocol employed for making the hydroxy polyimide precursor[55]. Furthermore, successfully copolymerization with polyimides has expanded its application area [7-11, 70]. Various physical properties of TR polymers rely on the thermal treatment conditions regarding benzoxazole formation (for instance, the percentage of conversion to PBO determines a balance between gas separation properties and mechanical strength). Since it was discovered that the introduction of sufficient rigidity in microporous organic polymers (MOPs) maintains good selectivity as well as high permeability [30]. Combination of TR-PBO and PIM produces materials with high rigid main chains, which resulted in membranes with much higher permeabilities along with good mechanical properties; however, the thermal rearrangement process produces also drops of gas 
selectivities due to increment cavities [52, 53, 71, 72]. In here, more details of TR polymers are going to be introduced by classification according to the chemical structures which have been widely developed for last decades.

\subsubsection{TR- $\alpha-P B O$ and TR- $\beta-P B O$}

TR-polymers can be broadly classified in two main groups, depending on the main chain structure of precursors: TR- $\alpha$-PBOs, which derived from hydroxy polyimides (HPI) and TR$\beta$-PBOs, which derived from hydroxy polyamides (HPA) as shown in Scheme 1-2. According to the differences of origin polymer structures, TR- $\alpha$-PBOs and TR- $\beta$-PBOs have shown kinetically and physically different properties even though the same polybenzoxazole structures can be formed. TR- $\alpha-\mathrm{PBO}$, as shown in Scheme 1-2(a), is derived from HPI synthesized from a dianhydride and a hydroxy diamine by solution imidization or thermal imidization (the details relay on imidization methods will be explained in next section). On the other hand, TR- $\beta$-PBO precursor is prepared using a dichloride instead of a dianhydride by straight polyamidation. During thermal rearrangement, cavities were formed by getting rid of $\mathrm{CO}_{2}$ from HPI, but of $\mathrm{H}_{2} \mathrm{O}$ from HPA. The emission of $\mathrm{H}_{2} \mathrm{O}$ for TR- $\beta$-PBO attributed to form

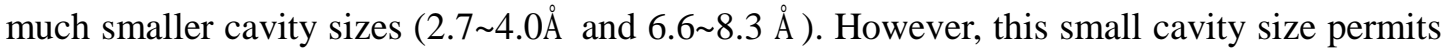
the separation of couple of small and big gases such as $\mathrm{H}_{2} / \mathrm{CO}_{2}, \mathrm{He} / \mathrm{CO}_{2}$. Also, the much higher mechanical properties and high selectivities of TR- $\beta-\mathrm{PBO}$ is much appreciated to applying for syn gas separations at high temperatures over $200^{\circ} \mathrm{C}$.[69] 
(a)

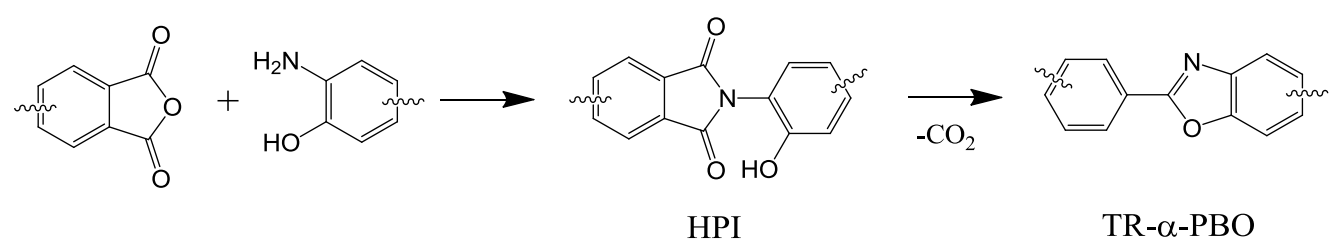

(b)

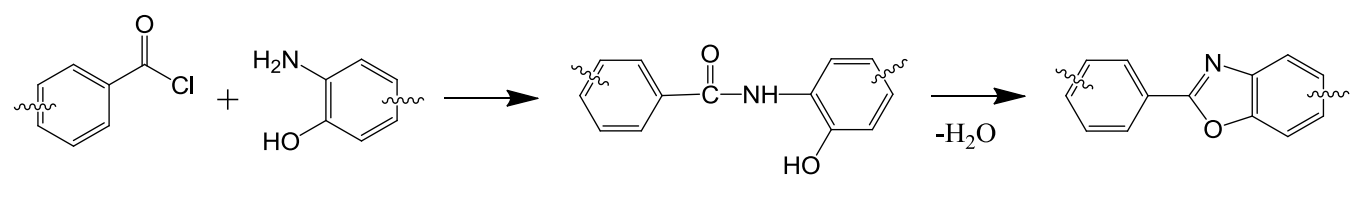

HPA

TR- $\beta-\mathrm{PBO}$

Scheme 1-2 Reaction of thermal rearrangement to (a) TR- $\alpha$-PBO which converted from hydroxy polyimide (HPI), and (b) TR- $\beta$-PBO from hydroxy polyamide (HPA)

\subsubsection{TR-tPBO, cPBO, aPBO, sPBO, ePBO}

Unlike TR- $\beta$-PBOs, TR- $\alpha$-PBOs have shown various ways to prepare according to synthetic methods of precursor polyimides. Interestingly, the preparation methods were critically effected on the gas transport properties of final TR-PBO membranes.[55] Scheme 13 summarized the five ways to prepare TR-PBOs that have been applied so far. And Figure 19 illustrated the variations of $\mathrm{CO}_{2}$ permeability and $\mathrm{CO}_{2} / \mathrm{CH}_{4}, \mathrm{O}_{2} / \mathrm{N}_{2}$ selectivity depending on the synthetic methods such as (i) thermal imidization, (ii) azeotropic imidization, (iii) chemical imidization, (iv) silylated chemical imidization, and (v) esterificated azeotropic imidization. Each precursor polyimides through each imidization method are designated as tHPI, aHPI, cHPI, sHPI, and eHPI, respectively, and final corresponding TR-PBOs also are named as tPBO, aPBO, cPBO, sPBO and ePBO. 
Imidization to prepare TR-PBOs can be classified in three main types; thermal, azeotropic, and chemical one. Thermal imidized HPI (tHPI) is obtained by solid-state film form by casting poly(amic acid) solution and final thermal treatment. Generally tHPI film is not soluble in organic solvents by inherently cross-linked site. Randomly formed polymer networks influence on formation of much bigger cavities for tPBO than for aPBO. Even though, high permeability materials are obtained, along with the use of a simpler process to prepare membranes, tPBO is not a good candidate for implementation because of the lack of reproducibility when it is fabricated as hollow fiber membranes. On the other hand, aHPI polymer network is linearly formed by eliminating water molecules during conversion from hydroxy poly(amic acid) to hydroxy polyimide and it have showed much better processability by using polymer powders whose molecular weights are controllable. As aPBO gives the lowest gas permeabilities due to relatively low increments of free volume by linear polymer chains, the improvement of permeabilities is one of the main issue of aPBO. ePBOs also produce similar performances as aPBOs.

cHPI and sHPI are obtained by chemical imidization that produces acetyl groups instead of hydroxy group at the ortho position. The thermally loss of acetyl groups before thermal rearrangement results in increases in cavity sizes and consequent increase of gas permeabilities. Thus, sPBO and cPBO showed much higher permeability than aPBO, tPBO and ePBO. However, the emission of ketene during thermal rearrangement from acetyl groups was warned due to its environmental hazardousness.

Regardless of the used route, the final TR-PBOs have shown mechanical fragilities which is the main drawback to applying these materials for gas separation. 


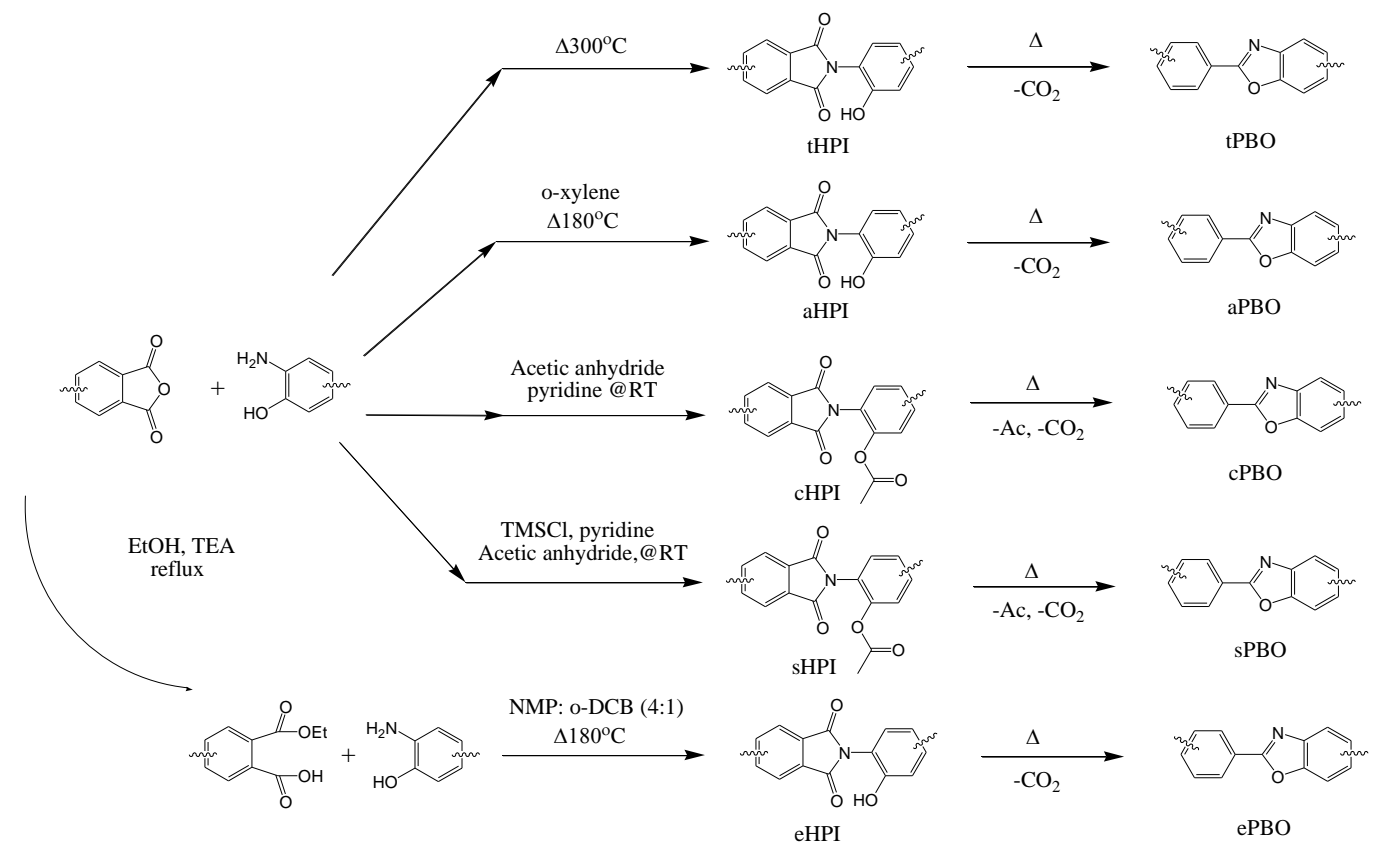

Scheme 1-3 Five synthetic routes to prepare TR- $\alpha$-PBOs.

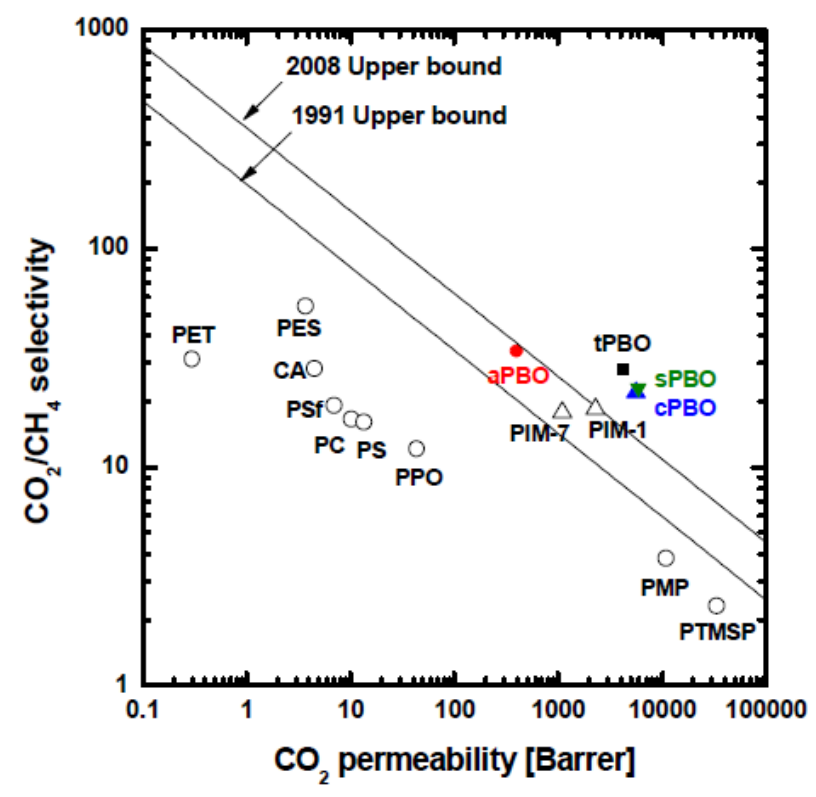

Figure 1-9 $\mathrm{CO}_{2}$ permeability and $\mathrm{CO}_{2} / \mathrm{CH}_{4}$ selectivity of TR-PBO membranes which depending various synthetic routes 


\subsubsection{Thermally Rearranged Copolymers}

Copolymerization is a good approach to improve physical properties of polymeric materials. In this way, TR polymers also have been copolymerized by combining with other polybenzoxazole structures, with polyimide, or with polypyrrolone which derived from three different diamines: ortho-hydroxy diamines, diamines or tetramines, respectively, as shown in Scheme 1-4. Yeong at al. found out that the addition of 10\% cardo-polybenzoxazole (CPBO) units which derived from a hydroxy diamine containing cardo group; 9,9'-bis(3-amino-4hydroxyphenyl)fluorine (bisAHPF), produced $420 \%$ increment of $\mathrm{CO}_{2}$ permeability as comparing with pure TR-PBO or TR-CPBO due to efficient free volume enhancement that translated to increases in $\mathrm{CO}_{2}$ and $\mathrm{CH}_{4}$ [10]solubility and diffusivity with drops in $\mathrm{CO}_{2} / \mathrm{CH}_{4}$ selectivity down to 26.[70]

Interestingly, ortho-amino polyimide (API), which can be converted to pyrrolone (PPL) structures by emitting water molecules during thermal treatment can be employed as copolymers of PBO. Thus, a API-co- HPI precursor was converted by thermal treatment to a poly(benzoxazole-co-pyrrolone) (PBO-co-PPL) membrane, which showed much lower permeability than TR-PBO; however, its $\mathrm{O}_{2} / \mathrm{N}_{2}$ selectivity was increased up to 7 and $\mathrm{CO}_{2} / \mathrm{CH}_{4}$ selectivity was 78 which are by far much higher value than those observed for pure TR-PBO and PPL due to the well-packed structure of PPL which controls diffusivity selectivity.[9]

Copolymerization using various pure diamines has been studied due to the tremendous chemical structures of diamines in nature.[7, 8, 10, 11] Firstly, Jung et al. developed TR-PBOI prepared by thermal imidization route, and it was observed the existence of a relationship 
between the ratio of diamine and hydroxy diamine, and gas permeabilities. The reduction of PBO ratio led to a decrease in permeabilities and an increase in selectivity [10]. The relationship with diamine part has deeply studied using eight non-TR-able (common aromatic diamines) diamines. Flat and rigid structure in the non-TR-able diamine resulted in much higher permeabilities than using diamines having flexible or entangled structures $[7,11]$. Not only the used non-TR-able diamines was important, also the TR-able (ortho-hydroxy diamines) diamines such as APAF and HAB, which are the most employed sources of TR-PBO materials, showed different thermal and physical behaviors. Mechanical properties of TR-PBOIs were much better than those showed by TR-PBOs and gas transport properties tuned according to polymer rigidity by controlling the non-TR-able and TR-able diamines ratio and the used chemical structures. These TR-PBOIs materials had much better gas transport properties than commercialized polymers such as cellulose acetate, polysulfones, polyimides and so on, therefore, the results of TR-PBOIs were meaningful for implementation to the practical gas separations [8].

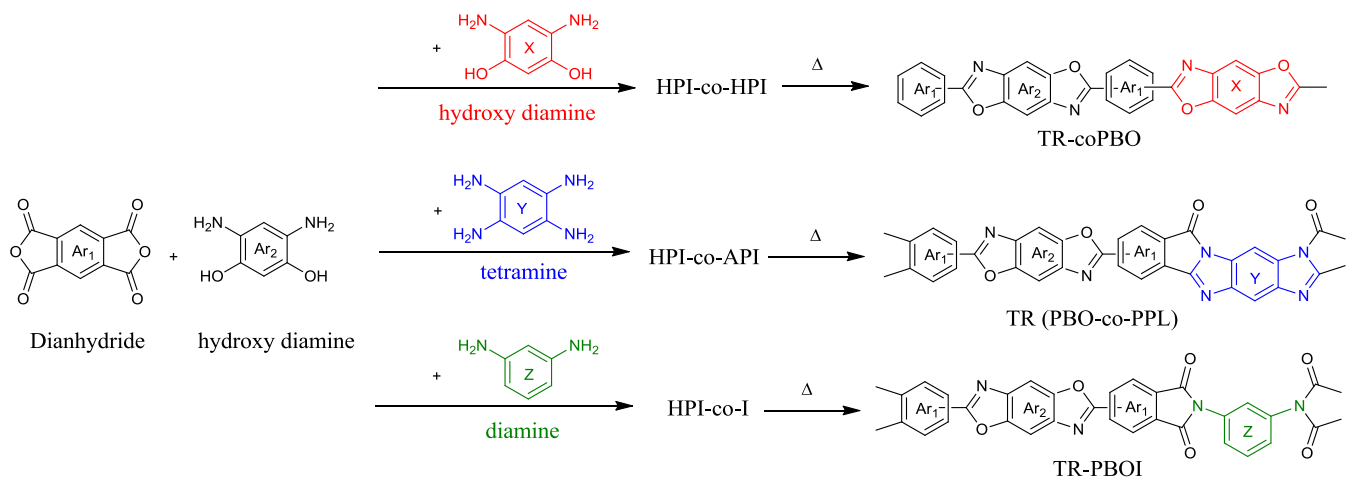

Scheme 1-4 Copolymerization routes based on three different diamines: a hydroxy diamine, tetramine, and diamine, to prepare TR-coPBO, TR(PBO-co-PPL) and TR-PBOI, respectively. 


\subsubsection{PIM-TR-PBO}

The kicked and contorted ladder-like structures of PIM consisting of spirobisindane group have obtained permeabilities higher than 2000 Barrer for $\mathrm{CO}_{2}$ by preventing chain packing and intrinsically producing 6-10§̊ cavities. These unique PIM structures have been mimicked with TR polymers, which can be called PIM-TR polymers in two ways: to construct the required ladder-like moiety in the anhydride part as shown in Figure 1-10(a) and (b), or to include this moiety in the hydroxy diamine part as seen in (c) and (d). [43, 52, 53] The performance of TR polymers containing spirobisindane groups should produce materials with much higher permeabilities, for example, the TR-PBO membrane based on SPDA-HSBF (Figure 1-10 (b) and (d)) showed more than 1200 Barrer for $\mathrm{CO}_{2}$.[72] Moreover, it can also be figured out that the use of spirobisindane groups could be a key factor of overcoming the mechanical fragility of TR-PBOs as has been observed in related works.[8]

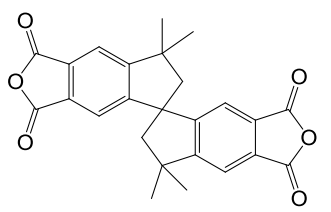

(a)

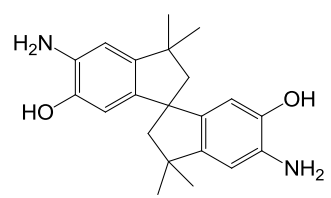

(c)

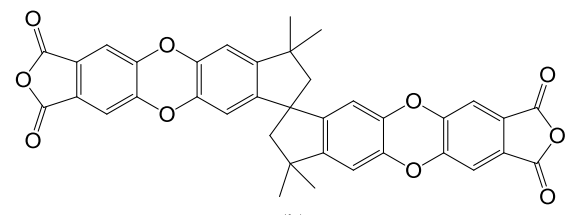

(b)

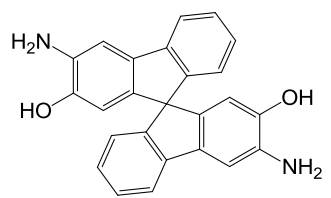

(d)

Figure 1-10 Chemical structure of (a)spirobisindane based dianhydride 1 (SPDA1), (b) spirobisindane based dianhydride 2 (SPDA2), (c) 3,3,3',3'-tetramehyl-1,1'-spirobisindane5,5'-diamino-6,6'-diol (TDSS), and (d) 2,2'-dihydroxyl-9.9'-spirobifluorene-2,2'-diamine (HSBF) 


\subsubsection{XTR-PBOIs}

As aforementioned, one of the plausible reasons of the higher free volume element sin TR materials can be derived from the inherent cross-linking formed during its formation.[55] Cross-linking processes adding DABA, as a co-monomer, into TR-polymers has been tried in chemically- and thermally-based polymers derived from 6FDA-APAF.[12, 13] Scheme 1-5 illustrates how to prepare chemically cross-linked TR-PBO (XTR-PBOI) polymers using butandiol and transesterification reactions. 10\% DABA-contained XTR-PBOI was obtained and its films showed much higher permeabilities (980 Barrer) than pure TR-PBO (260 Barrer) but no exact relationship with DABA ratio was found. On the other hand, thermally crosslinking polymer films only showed 619 Barrer when 10\% DABA was used in the polymer backbone. Again, the relationship between DABA ratio and properties was not determined. However, these studies have proved the cross-linking has a synergetic effects on enlarging cavity sizes, and consequently on improving the gas permeabilities. 

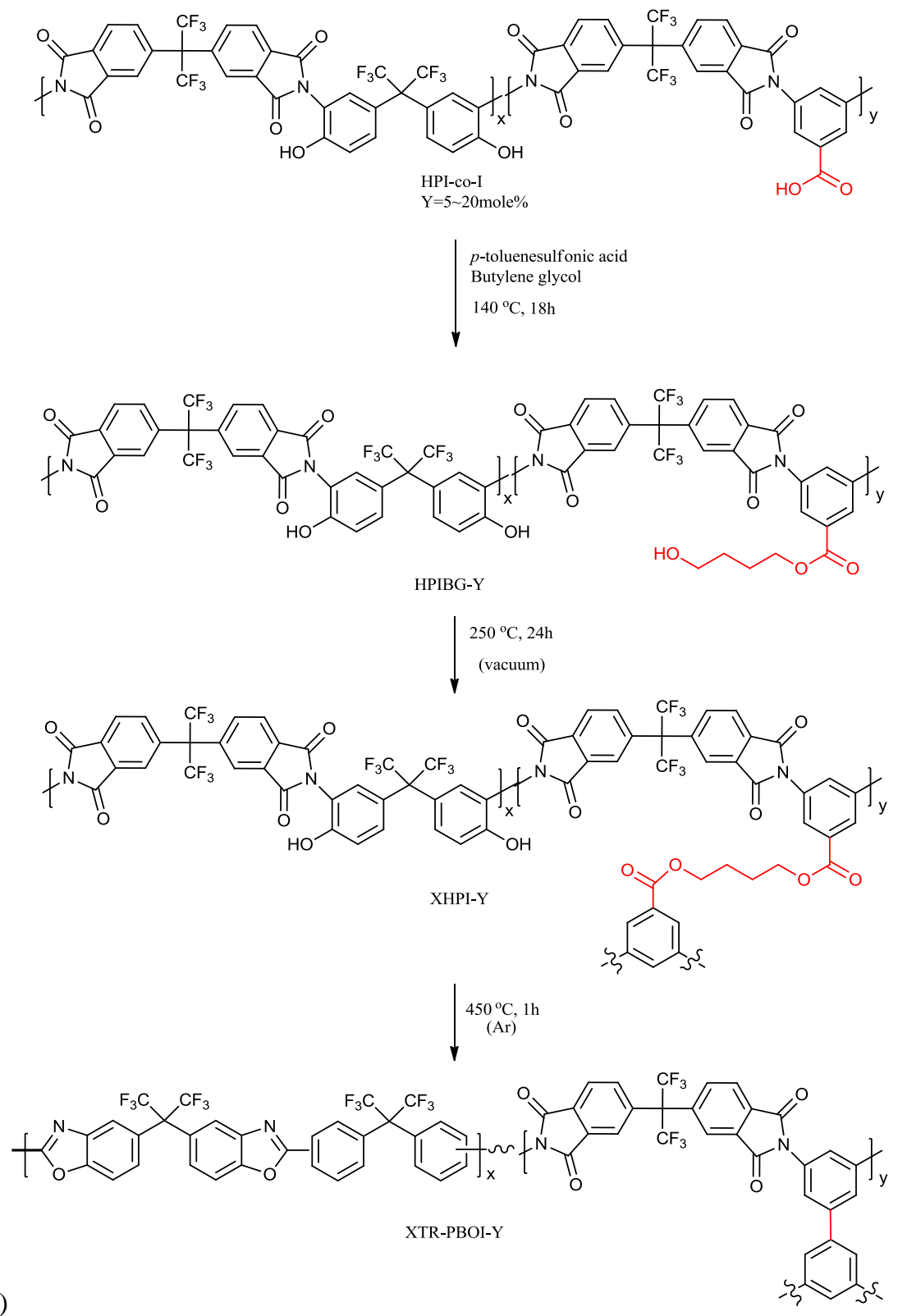

(a) 

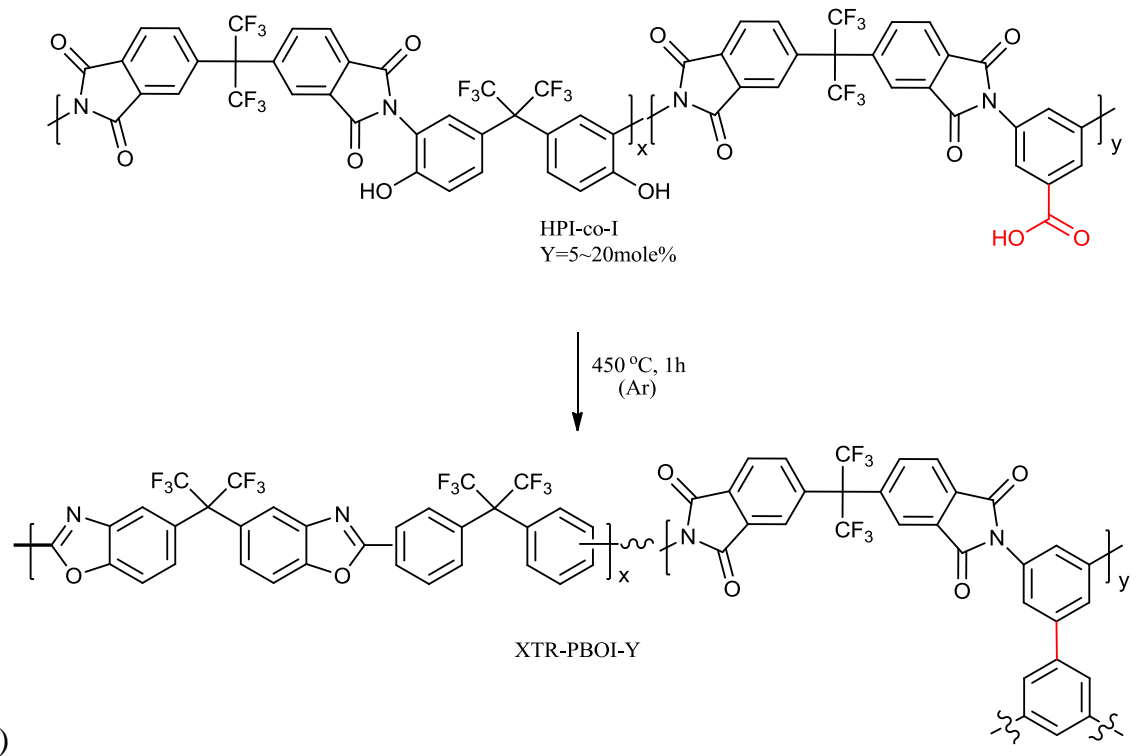

Scheme 1-5 (a) The chemical way to prepare XTR-PBOIs by synthesizing XHPI by butandiol transesterification [12], and (b) the preparation of thermally induced XTR-PBOI directly from hydroxy copolyimide (HPI-co-I) by heat treatment under argon purging [13]

\subsection{Conclusion}

Thermal rearranged (TR) polymers are emerging materials especially for gas separation applications because they show high permeabilities and reasonable selectivities due to the presence in the membrane of bimodal cavities. Well-designed tunability of TR-polymers is one attractive point of research to be applied for a determined gas separation process. For that, it is important, in order to design useable materials, to understand the relationship of gas transport properties with the chemical structure as well as its thermal behavior to know when and how thermal conversion taken place. Despite of their high permeabilities, the fragility (poor mechanical properties) of TR-PBOs handicaps its implementation in industrial (real-world) applications so that the search of ways to produce an enhancement of mechanical properties is 
one of the most required research areas. Herein, this research work is focused on improving not only gas permeabilities but also mechanical properties. This understanding should permit the rational development of chemical structures of precursor polymer and corresponding TR polymers, which should lead to materials able to be employed in practical and industrial gas separation processes.

\section{References}

[1] P. Bernardo, E. Drioli, G. Golemme, Membrane Gas Separation: A Review/State of the Art, Ind. Eng. Chem. Res., 48 (2009) 4638-4663.

[2] R.W. Baker, Future directions of membrane gas separation technology, Ind. Eng. Chem. Res., 41 (2002) 1393-1411.

[3] E. Drioli, A.I. Stankiewicz, F. Macedonio, Membrane engineering in process intensification-An overview, Journal of Membrane Science, 380 (2011) 1-8.

[4] J.G. Wijmans, R.W. Baker, THE SOLUTION-DIFFUSION MODEL - A REVIEW, Journal of Membrane Science, 107 (1995) 1-21.

[5] L.M. Robeson, The upper bound revisited, Journal of Membrane Science, 320 (2008) 390400.

[6] H.B. Park, C.H. Jung, Y.M. Lee, A.J. Hill, S.J. Pas, S.T. Mudie, E. Van Wagner, B.D. Freeman, D.J. Cookson, Polymers with cavities tuned for fast selective transport of small molecules and ions, Science, 318 (2007) 254-258.

[7] C.Y. Soo, H.J. Jo, Y.M. Lee, J.R. Quay, M.K. Murphy, Effect of the chemical structure of various diamines on the gas separation of thermally rearranged poly(benzoxazole-co-imide) 
(TR-PBO-co-I) membranes, Journal of Membrane Science, 444 (2013) 365-377.

[8] H.J. Jo, C.Y. Soo, G. Dong, Y.S. Do, H.H. Wang, M.J. Lee, J.R. Quay, M.K. Murphy, Y.M. Lee, Thermally Rearranged Poly(benzoxazole-co-imide) Membranes with Superior Mechanical Strength for Gas Separation Obtained by Tuning Chain Rigidity, Macromolecules, 48 (2015) 2194-2202.

[9] J.I. Choi, C.H. Jung, S.H. Han, H.B. Park, Y.M. Lee, Thermally rearranged (TR) poly(benzoxazole-co-pyrrolone) membranes tuned for high gas permeability and selectivity, Journal of Membrane Science, 349 (2010) 358-368.

[10] C.H. Jung, J.E. Lee, S.H. Han, H.B. Park, Y.M. Lee, Highly permeable and selective poly(benzoxazole-co-imide) membranes for gas separation, Journal of Membrane Science, 350 (2010) 301-309.

[11] C.A. Scholes, C.P. Ribeiro, S.E. Kentish, B.D. Freeman, Thermal rearranged poly(benzoxazole-co-imide) membranes for CO2 separation, Journal of Membrane Science, 450 (2014) 72-80.

[12] M. Calle, C.M. Doherty, A.J. Hill, Y.M. Lee, Cross-Linked Thermally Rearranged Poly(benzoxazole-co-imide) Membranes for Gas Separation, Macromolecules, 46 (2013) 8179-8189.

[13] M. Calle, H.J. Jo, C.M. Doherty, A.J. Hill, Y.M. Lee, Cross-Linked Thermally Rearranged Poly(benzoxazole-co-imide) Membranes Prepared from ortho-Hydroxycopolyimides Containing Pendant Carboxyl Groups and Gas Separation Properties, Macromolecules, 48 (2015) 2603-2613.

[14] R.J.R. Uhlhorn, K. Keizer, A.J. Burggraaf, GAS AND SURFACE-DIFFUSION IN MODIFIED GAMMA-ALUMINA SYSTEMS, Journal of Membrane Science, 46 (1989) 225- 
241.

[15] G. Maier, Gas separation with polymer membranes, Angewandte Chemie-International Edition, 37 (1998) 2961-2974.

[16] E. Smit, M.H.V. Mulder, C.A. Smolders, H. Karrenbeld, J. Vaneerden, D. Feil, MODELING OF THE DIFFUSION OF CARBON-DIOXIDE IN POLYIMIDE MATRICES BY COMPUTER-SIMULATION, Journal of Membrane Science, 73 (1992) 247-257.

[17] Y. Yamoilskii, I. Pinnau, B. Freeman, Materials Science of Membranes for Gas and Vapor Separation, 2006.

[18] M.H. Cohen, D. Turnbull, MOLECULAR TRANSPORT IN LIQUIDS AND GLASSES, Journal of Chemical Physics, 31 (1959) 1164-1169.

[19] E. Drioli, Membrane Operations.

[20] M.S. McCaig, D.R. Paul, Effect of film thickness on the changes in gas permeability of a glassy polyarylate due to physical aging Part I. Experimental observations, Polymer, 41 (2000) 629-637.

[21] Y. Xiao, B.T. Low, S.S. Hosseini, T.S. Chung, D.R. Paul, The strategies of molecular architecture and modification of polyimide-based membranes for CO2 removal from natural gas-A review, Progress in Polymer Science, 34 (2009) 561-580.

[22] J.K. Adewole, A.L. Ahmad, S. Ismail, C.P. Leo, Current challenges in membrane separation of CO2 from natural gas: A review, International Journal of Greenhouse Gas Control, 17 (2013) 46-65.

[23] X.Y. Chen, H. Vinh-Thang, A.A. Ramirez, D. Rodrigue, S. Kaliaguine, Membrane gas separation technologies for biogas upgrading, RSC Adv., 5 (2015) 24399-24448.

[24] J.D. Figueroa, T. Fout, S. Plasynski, H. McIlvried, R.D. Srivastava, Advancesn in CO(2) 
capture technology - The US Department of Energy's Carbon Sequestration Program, International Journal of Greenhouse Gas Control, 2 (2008) 9-20.

[25] T.C. Merkel, H. Lin, X. Wei, R. Baker, Power plant post-combustion carbon dioxide capture: An opportunity for membranes, J. Membr. Sci., 359 (2010) 126-139.

[26] T.C. Merkel, M. Zhou, R.W. Baker, Carbon dioxide capture with membranes at an IGCC power plant, Journal of Membrane Science, 389 (2012) 441-450.

[27] L.M. Robeson, Correlation of separation factor versus permeability for polymeric membranes, Journal of Membrane Science, 62 (1991) 165-185.

[28] H. Lin, M. Yavari, Upper bound of polymeric membranes for mixed-gas CO2/CH4 separations, Journal of Membrane Science, 475 (2015) 101-109.

[29] M. Carta, R. Malpass-Evans, M. Croad, Y. Rogan, J.C. Jansen, P. Bernardo, F. Bazzarelli, N.B. McKeown, An Efficient Polymer Molecular Sieve for Membrane Gas Separations, Science, 339 (2013) 303-307.

[30] M.D. Guiver, Y.M. Lee, Polymer Rigidity Improves Microporous Membranes, Science, 339 (2013) 284-285.

[31] P.M. Budd, E.S. Elabas, B.S. Ghanem, S. Makhseed, N.B. McKeown, K.J. Msayib, C.E. Tattershall, D. Wang, Solution-processed, organophilic membrane derived from a polymer of intrinsic microporosity, Advanced Materials, 16 (2004) 456-+.

[32] P.M. Budd, K.J. Msayib, C.E. Tattershall, B.S. Ghanem, K.J. Reynolds, N.B. McKeown, D. Fritsch, Gas separation membranes from polymers of intrinsic microporosity, Journal of Membrane Science, 251 (2005) 263-269.

[33] C.L. Staiger, S.J. Pas, A.J. Hill, C.J. Cornelius, Gas separation, free volume distribution, and physical aging of a highly microporous spirobisindane polymer, Chemistry of Materials, 
20 (2008) 2606-2608.

[34] N. Du, H.B. Park, G.P. Robertson, M.M. Dal-Cin, T. Visser, L. Scoles, M.D. Guiver, Polymer nanosieve membranes for CO2-capture applications, Nature materials, 10 (2011) 372375.

[35] C.G. Bezzu, M. Carta, A. Tonkins, J.C. Jansen, P. Bernardo, F. Bazzarelli, N.B. McKeown, A spirobifluorene-based polymer of intrinsic microporosity with improved performance for gas separation, Advanced materials, 24 (2012) 5930-5933.

[36] J. Zhang, J. Jin, R. Cooney, S. Zhang, Synthesis of polymers of intrinsic microporosity using an AB-type monomer, Polymer, 57 (2015) 45-50.

[37] M. Carta, P. Bernardo, G. Clarizia, J.C. Jansen, N.B. McKeown, Gas Permeability of Hexaphenylbenzene Based Polymers of Intrinsic Microporosity, Macromolecules, 47 (2014) 8320-8327.

[38] M. Carta, M. Croad, R. Malpass-Evans, J.C. Jansen, P. Bernardo, G. Clarizia, K. Friess, M. Lanc, N.B. McKeown, Triptycene Induced Enhancement of Membrane Gas Selectivity for Microporous Troger's Base Polymers, Advanced Materials, 26 (2014) 3526-3531.

[39] N. Du, M.M. Dal-Cin, G.P. Robertson, M.D. Guiver, Decarboxylation-Induced CrossLinking of Polymers of Intrinsic Microporosity (PIMs) for Membrane Gas Separation†, Macromolecules, 45 (2012) 5134-5139.

[40] F.Y. Li, Y. Xiao, T.-S. Chung, S. Kawi, High-Performance Thermally Self-Cross-Linked Polymer of Intrinsic Microporosity (PIM-1) Membranes for Energy Development, Macromolecules, 45 (2012) 1427-1437.

[41] F.Y. Li, T.-S. Chung, Physical aging, high temperature and water vapor permeation studies of UV-rearranged PIM-1 membranes for advanced hydrogen purification and production, 
International Journal of Hydrogen Energy, 38 (2013) 9786-9793.

[42] Q. Song, S. Cao, R.H. Pritchard, B. Ghalei, S.A. Al-Muhtaseb, E.M. Terentjev, A.K. Cheetham, E. Sivaniah, Controlled thermal oxidative crosslinking of polymers of intrinsic microporosity towards tunable molecular sieve membranes, Nature Communications, 5 (2014). [43] X. Ma, B. Ghanem, O. Salines, E. Litwiller, I. Pinnau, Synthesis and Effect of Physical Aging on Gas Transport Properties of a Microporous Polyimide Derived from a Novel Spirobifluorene-Based Dianhydride, ACS Macro Letters, 4 (2015) 231-235.

[44] R. Swaidan, M. Al-Saeedi, B. Ghanem, E. Litwiller, I. Pinnau, Rational Design of Intrinsically Ultramicroporous Polyimides Containing Bridgehead-Substituted Triptycene for Highly Selective and Permeable Gas Separation Membranes, Macromolecules, 47 (2014) $5104-5114$

[45] J.R. Wiegand, Z.P. Smith, Q. Liu, C.T. Patterson, B.D. Freeman, R. Guo, Synthesis and characterization of triptycene-based polyimides with tunable high fractional free volume for gas separation membranes, Journal of Materials Chemistry A, 2 (2014) 13309.

[46] B.S. Ghanem, R. Swaidan, E. Litwiller, I. Pinnau, Ultra-microporous triptycene-based polyimide membranes for high-performance gas separation, Advanced materials, 26 (2014) 3688-3692.

[47] X. Ma, O. Salinas, E. Litwiller, I. Pinnau, Novel Spirobifluorene- and Dibromospirobifluorene-Based Polyimides of Intrinsic Microporosity for Gas Separation Applications, Macromolecules, 46 (2013) 9618-9624.

[48] Y.J. Cho, H.B. Park, High performance polyimide with high internal free volume elements, Macromolecular rapid communications, 32 (2011) 579-586.

[49] S. Fu, E.S. Sanders, S.S. Kulkarni, W.J. Koros, Carbon molecular sieve membrane 
structure-property relationships for four novel 6FDA based polyimide precursors, Journal of Membrane Science, 487 (2015) 60-73.

[50] W. Qiu, K. Zhang, F.S. Li, K. Zhang, W.J. Koros, Gas separation performance of carbon molecular sieve membranes based on 6FDA-mPDA/DABA (3:2) polyimide, ChemSusChem, 7 (2014) 1186-1194.

[51] B.T. Low, T.S. Chung, Carbon molecular sieve membranes derived from pseudointerpenetrating polymer networks for gas separation and carbon capture, Carbon, 49 (2011) 2104-2112.

[52] S. Li, H.J. Jo, S.H. Han, C.H. Park, S. Kim, P.M. Budd, Y.M. Lee, Mechanically robust thermally rearranged (TR) polymer membranes with spirobisindane for gas separation, Journal of Membrane Science, 434 (2013) 137-147.

[53] H. Shamsipur, B.A. Dawood, P.M. Budd, P. Bernardo, G. Clarizia, J.C. Jansen, Thermally Rearrangeable PIM-Polyimides for Gas Separation Membranes, Macromolecules, 47 (2014) $5595-5606$

[54] B. Comesana-Gandara, M. Calle, H.J. Jo, A. Hernandez, J.G. de la Campa, J. de Abajo, A.E. Lozano, Y.M. Lee, Thermally rearranged polybenzoxazoles membranes with biphenyl moieties: Monomer isomeric effect, Journal of Membrane Science, 450 (2014) 369-379.

[55] S.H. Han, N. Misdan, S. Kim, C.M. Doherty, A.J. Hill, Y.M. Lee, Thermally Rearranged (TR) Polybenzoxazole: Effects of Diverse Imidization Routes on Physical Properties and Gas Transport Behaviors, Macromolecules, 43 (2010) 7657-7667.

[56] D.F. Sanders, Z.P. Smith, C.P. Ribeiro, Jr., R. Guo, J.E. McGrath, D.R. Paul, B.D. Freeman, Gas permeability, diffusivity, and free volume of thermally rearranged polymers based on 3,3 '-dihydroxy-4,4 '-diamino-biphenyl (HAB) and 2,2 '-bis-(3,4-dicarboxyphenyl) 
hexafluoropropane dianhydride (6FDA), Journal of Membrane Science, 409 (2012) 232-241.

[57] G.L. Tullos, L.J. Mathias, Unexpected thermal conversion of hydroxy-containing polyimides to polybenzoxazoles, Polymer, 40 (1999) 3463-3468.

[58] G.L. Tullos, J.M. Powers, S.J. Jeskey, L.J. Mathias, Thermal conversion of hydroxycontaining imides to benzoxazoles: Polymer and model compound study, Macromolecules, 32 (1999) 3598-3612.

[59] J.H. Chang, K.M. Park, S.M. Lee, J.B. Oh, Two-step thermal conversion from poly(amic acid) to polybenzoxazole via polyimide: Their thermal and mechanical properties, J Polym Sci Pol Phys, 38 (2000) 2537-2545.

[60] S. Kim, S.H. Han, Y.M. Lee, Thermally rearranged (TR) polybenzoxazole hollow fiber membranes for CO2 capture, Journal of Membrane Science, 403-404 (2012) 169-178.

[61] K.T. Woo, J. Lee, G. Dong, J.S. Kim, Y.S. Do, W.S. Hung, K.R. Lee, G. Barbieri, E. Drioli, Y.M. Lee, Fabrication of thermally rearranged (TR) polybenzoxazole hollow fiber membranes with superior $\mathrm{CO}_{2} / \mathrm{N}_{2}$ separation performance, Journal of Membrane Science, 490 (2015) 129138.

[62] Y.K. Ong, H. Wang, T.S. Chung, A prospective study on the application of thermally rearranged acetate-containing polyimide membranes in dehydration of biofuels via pervaporation, Chemical Engineering Science, 79 (2012) 41-53.

[63] C.H. Lee, Y.M. Lee, Highly proton-conductive thermally rearranged polybenzoxazole for medium-temperature and low-humidity polymer electrolyte fuel cells, Journal of Power Sources, 247 (2014) 286-293.

[64] M.J. Lee, J.H. Kim, H.S. Lim, S.Y. Lee, H.K. Yu, J.H. Kim, J.S. Lee, Y.K. Sun, M.D. Guiver, K.D. Suh, Y.M. Lee, Highly lithium-ion conductive battery separators from thermally 
rearranged polybenzoxazole, Chemical Communications, 51 (2015) 2068-2071.

[65] H.B. Park, S.H. Han, C.H. Jung, Y.M. Lee, A.J. Hill, Thermally rearranged (TR) polymer membranes for CO2 separation, Journal of Membrane Science, 359 (2010) 11-24.

[66] M. Calle, Y.M. Lee, Thermally Rearranged (TR) Poly(ether-benzoxazole) Membranes for Gas Separation, Macromolecules, 44 (2011) 1156-1165.

[67] H. Wang, D.R. Paul, T.-S. Chung, The effect of purge environment on thermal rearrangement of ortho-functional polyamide and polyimide, Polymer, 54 (2013) 2324-2334. [68] R. Guo, D.F. Sanders, Z.P. Smith, B.D. Freeman, D.R. Paul, J.E. McGrath, Synthesis and characterization of thermally rearranged (TR) polymers: effect of glass transition temperature of aromatic poly(hydroxyimide) precursors on TR process and gas permeation properties, Journal of Materials Chemistry A, 1 (2013) 6063-6072.

[69] S.H. Han, H.J. Kwon, K.Y. Kim, J.G. Seong, C.H. Park, S. Kim, C.M. Doherty, A.W. Thornton, A.J. Hill, Á.E. Lozano, K.A. Berchtold, Y.M. Lee, Tuning microcavities in thermally rearranged polymer membranes for CO 2 capture, Physical Chemistry Chemical Physics, 14 (2012) 4365-4373.

[70] Y.F. Yeong, H. Wang, K. Pallathadka Pramoda, T.S. Chung, Thermal induced structural rearrangement of cardo-copolybenzoxazole membranes for enhanced gas transport properties, Journal of Membrane Science, 397-398 (2012) 51-65.

[71] D.F. Sanders, R. Guo, Z.P. Smith, Q. Liu, K.A. Stevens, J.E. McGrath, D.R. Paul, B.D. Freeman, Influence of polyimide precursor synthesis route and ortho-position functional group on thermally rearranged (TR) polymer properties: Conversion and free volume, Polymer, 55 (2014) 1636-1647.

[72] X. Ma, O. Salinas, E. Litwiller, I. Pinnau, Pristine and thermally-rearranged gas separation 
membranes from novel o-hydroxyl-functionalized spirobifluorene-based polyimides, Polymer Chemistry, 5 (2014) 6914-6922. 
Chapter 2

\section{The Relationship between the Chemical Structure and Thermal Conversion Temperatures of}

\section{Thermally Rearranged (TR) Polymers}

This paper has been published as: M. Calle, Y. Chan, H.J. Jo, Y.M. Lee, The relatio nship between the chemical structure and thermal conversion temperatures of therma lly rearranged (TR) polymers, Polymer, 53 (2012) 2783-2791. 


\subsection{Introduction}

In-situ thermal conversions of ortho-hydroxy-containing polyimides (HPIs) to polybenzoxazoles (PBOs) have been widely reported. Likhatchev and co-workers studied for the first time the thermal behaviour of soluble aromatic polyimides based on 2,2'-bis(3-amino4-hydroxyphenyl)hexafluoropropane (APAF) diamine and several aromatic dianhydrides (i.e. pyromellitic dianhydride (PMDA), 3,3',4,4'-benzophenonetetracarboxylic acid dianhydride (BTDA) and 4,4'-oxydiphthalic anhydride (ODPA)) [1]. They established that the thermal conversion of hydroxypolyimides to polybenzoxazoles proceeds through a carboxybenzoxazole intermediate, followed by decarboxylation to give the fully aromatic final benzoxazole (Scheme 2-1).

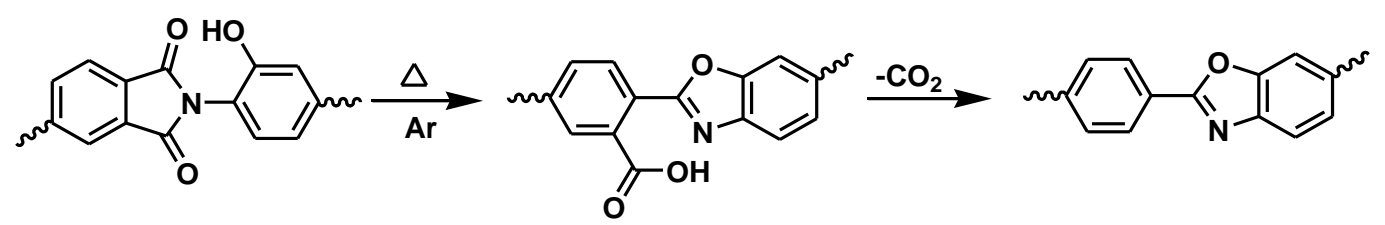

Scheme 2-1 Proposed reaction for thermal conversion of hydroxy-imide to benzoxazole.

The carbon dioxide evolution from the decarboxylation step was easily detected by thermogravimetric analysis (TGA) as a well-defined, weight-loss step prior to the generalyzed decomposition of the in-situ formed polybenzoxazole. Thus, they claimed that the starting temperature of weight loss and the temperature at the peak (maximum amount of $\mathrm{CO}_{2}$ evolution temperature) in the derivative thermogravimetric curves (DTG) were controlled to some extent by the structure of dianhydride moiety. In fact, the imide-to-benzoxazole rearrangement shifted 
to lower temperatures as a function of increasing flexibility in the dianhydride moiety. Subsequently, Tullos and his colleagues carried out a more in depth study about the thermal rearrangement of several structurally different $o$-hydroxy polyimides derived from different bis(o-aminophenol)s such APAF and 3,3'-dihydroxybenzidine (HAB), and several dianhydrides such as 3,3',4,4'-bisphenyltetracarboxylic dianhydride (BPDA), 4,4'(hexafluoroisopropylidene)diphthalic anhydride $\quad$ 6FDA, 4,4'-(4,4'isopropylidenediphenoxy)bis(phthalicanhydride) BPADA, BTDA, and ODPA, in an attempt to confirm the final rearranged polymer structure and the thermal conversion mechanism [2,3]. In fact, they reasserted the previously established imide-to-polybenzoxazole rearrangement mechanism, and found that the more flexible hydroxy-containing polyimides, with lower glass transition temperatures, underwent thermal conversion at a faster rate and at a lower temperature. However, Tullos and his colleagues did not establish a clear and direct relationship between the thermal rearrangement or conversion temperature $\left(T_{T R}\right)$ and glass transition temperature $(T g)$ of the precursor polyimides. After their report, several studies have described the thermal conversion of HPIs to PBOs [4-7], but none of them have centered on claryfing the possible connection between $\mathrm{T}_{\mathrm{g}}$ and $T_{T R}$.

Recently we found that thermally rearranged (TR) polybenzoxazole membranes show unusual microporous characteristics resulting from a significant increase of free volume elements during the thermal rearrangement process in the solid state [8-12]. These TR-polymer membranes are promising materials for gas separation applications, such as $\mathrm{CO}_{2}$ separation for carbon capture, since they show outstanding gas performance, particularly for the gas pairs $\mathrm{CO}_{2} / \mathrm{CH}_{4}$ and $\mathrm{CO}_{2} / \mathrm{N}_{2}$ [13]. One of the crucial factors to design a cost effective thermal 
treatment process for TR-polymers, is the thermal rearrangement or conversion temperature $\left(T_{T R}\right)$. This temperature, as pointed out above, can be predicted to be greatly influenced by the polymer morphology and chemical structure.

Therefore, it is our objective to explore the relationship between the chain mobility, $\mathrm{T}_{\mathrm{g}}$ and $T_{T R}$ for this family of $o$-hydroxy polyimides. As a continuation in our studies about TR-PBO polymer membranes and for further understanding on how $T_{T R}$ is affected by the chemical structure of $o$-hydroxy polyimides, herein we have examined in detail the differential scanning calorimetry (DSC) and TGA thermograms, accompained by DTG curves for a large set of $o$ hydroxy polyimides and copolyimides. A great variety of different chemical structures have been synthesized, from two commercially available bis(o-aminophenol)s, (APAF and HAB), and two experimental ones, 2,2-Bis(4-(4-amino-3-hydroxyphenoxy)phenyl) hexafluoropropane (6FBAHPP) and 1,4-Bis(4-amino-3-hydroxyphenoxy) 2,5-di-tertbutylbenzene (TBAHPB), incorporating flexible connecting linkages, together with three commercial, commonly used dianhydrides, such as, BPDA, 6FDA and BPADA.

\subsection{Experimental Section}

\subsubsection{Materials}

Solvents and reactants were of reagent-grade quality and used without further purification. 5-Fluoro-2-nitrophenol, hydrazine monohydrate and palladium $10 \mathrm{wt} \%$ on activated carbon were purchased from Aldrich, 4,4'-(hexafluoroisopropylidene)diphenol and 2,5-di-tert-butyl hydroquinone to Alfa Aesar, and 5-fluoro-2-nitroanisole from Apollo (U.K). The dianhydride 
3,3',4,4'-bisphenyltetracarboxylic dianhydride (BPDA), was purchased from Shanghai Resin Factory Co., Ltd. (China), 4,4'-(4,4'-isopropylidenediphenoxy)bis(phthalicanhydride) (BPADA) was purchased from Aldrich and the 4,4'-(hexafluoroisopropylidene)diphthalic anhydride (6FDA) from Daikin Industries, Ltd. (Osaka, Japan). The diamines, 2,2'-bis(3amino-4-hydroxyphenyl) hexafluoropropane (APAF) was purchased from Central Glass Co. Ltd (Tokyo, Japan) and the 3,3'-dihydroxybenzidine (HAB) from Tokyo Chemical Industry (TCI) Co., Ltd. (Tokyo, Japan).

\subsubsection{Monomers Synthesis}

\subsubsection{Synthesis of 2,2-Bis(4-(4-amino-3-hydroxyphenoxy)phenyl) hexafluoropropane} $(6 F B A H P P)$

It was synthesized in two steps, according to the previously reported method [14-15], from 4,4'-(hexafluoroisopropylidene)diphenol and 5-fluoro-2-nitrophenol by nucleophilic aromatic substitution in the presence of potassium carbonate $\left(\mathrm{K}_{2} \mathrm{CO}_{3}\right)$ and DMF as solvent, followed by catalytic reduction with hydrazine hydrate and $\mathrm{Pd} / \mathrm{C}$ as a catalyst. Elemental analyses and ${ }^{1} \mathrm{H}$ NMR data of intermediate and final monomers have been recently reported elsewhere [14].

\subsubsection{Synthesis of 1,4-Bis(3-methoxy-4-nitrophenoxy)2,5-di-tert-butylbenzene (1)}

The dinitro dimethoxylated intermediate $\mathbf{1}$ was synthesized by the reaction of 2,5-di-tertbutylhydroquinone (11.12 g, $50 \mathrm{mmol}$ ) and 5-fluoro-2-nitroanisole (18.82 g, $110 \mathrm{mmol})$ in the presence of potassium carbonate (15.48 g, $112 \mathrm{~mol})$ and DMF $(100 \mathrm{~mL})$ at $160{ }^{\circ} \mathrm{C}$ for 18 hours. The mixture was then cooled and poured into distilled water, filtered, and washed again with 
water. The crude product was recrystallized from DMF to provide a yellow solid. The yield was 85\%. mp $243{ }^{\circ} \mathrm{C}$. Elemental Anal. Calcd. For $\mathrm{C}_{28} \mathrm{H}_{32} \mathrm{~N}_{2} \mathrm{O}_{8}$ : C, 64.11; H, 6.15; N, 5.34; Found: C, 63.95; H, 6.10; N, 5.20. ${ }^{1} \mathrm{H}$ NMR (300 MHz, DMSO-d $)$ ): 8.00 (d, 2H, $J=9.1 \mathrm{~Hz}$ ), 7.00 (s, 2H), 6.96 (d, 2H, $J=2.2 \mathrm{~Hz}), 6.51$ (dd, 2H, $J=2.2 \mathrm{~Hz}, J=9.1 \mathrm{~Hz}$ ), 3.39 (s, 6H).

\subsubsection{Synthesis of 1,4-Bis(3-hydroxy-4-nitrophenoxy)2,5-di-tert-butylbenzene (2).}

A mixture of $9.00 \mathrm{~g}$ (11.44 mmol) of $\mathbf{1}$ and $54.0 \mathrm{~g}$ of pyridine hydrochloride was heated at $160{ }^{\circ} \mathrm{C}$ for 24 hours under nitrogen. The reaction mixture was then poured into distilled water. Then the precipitate was collected by filtration, and the crude product was washed with water and dried. The product was recrystallized from penthanol to afford a brown solid. The yield was 65 \%. mp $248{ }^{\circ} \mathrm{C}$. Elemental Anal. Calcd. For $\mathrm{C}_{26} \mathrm{H}_{28} \mathrm{~N}_{2} \mathrm{O}_{8}$ : C, 62.89; H, 5.68; N, 5.64;

Found: C, 62.65; H, 5.45; N, 5.50. ${ }^{1} \mathrm{H}$ NMR (300 MHz, DMSO-d 6 ): 11.19 (s, 2H), 8.05 (d, 2H, $J=8.6 \mathrm{~Hz}$ ), 7.00 (s, 2H), 6.59 (d, 2H, $J=1.9 \mathrm{~Hz}), 6.50$ (dd, 2H, $J=1.9 \mathrm{~Hz}, J=8.6 \mathrm{~Hz})$.

\subsubsection{Synthesis of 1,4-Bis(4-amino-3-hydroxyphenoxy)2,5-di-tert-butylbenzene (TBAHPB)}

A flask was charged with 2 (5 g, $10.07 \mathrm{mmol}), 25.0 \mathrm{ml}$ of hydrazine monohydrate, $40 \mathrm{ml}$ of ethanol, and $0.100 \mathrm{~g}$ of $10 \%$ palladium on carbon (Pd-C). The mixture was heated to reflux for 20 hours. After this time, the reaction suspension was poured into distilled water. The precipitate was collected by filtration, and the crude solid was recrystallized using a mixed solution of DMF (DMF:water = 2:1, v/v) under a nitrogen atmosphere. The removing of the Pd-C catalyst was carried in the recrystallization step by filtering through Celite. The yield was 70 \%. mp $335{ }^{\circ}$ C. Elemental Anal. Calcd. For $\mathrm{C}_{26} \mathrm{H}_{32} \mathrm{~N}_{2} \mathrm{O}_{4}$ C, 71.53; H, 7.39; N, 6.42; Found: C, 71.35; H, 7.10; N, 6.20. ${ }^{1} \mathrm{H}$ NMR (300 MHz, DMSO-d 6 ): 9.20 (s (broad), 2H), 6.69 (s, 2H), 6.55 (d, 2H, $J=8.6 \mathrm{~Hz}), 6.33$ (d, 2H, $J=2.5 \mathrm{~Hz}), 6.22$ (dd, 2H, $J=2.5 \mathrm{~Hz}, J=8.6 \mathrm{~Hz}), 4.30$ (s 
(broad), 4H).

\subsubsection{Poly $(o$-hydroxyimide)s synthesis}

A three-necked flask, equipped with a mechanical stirrer and gas inlet and outlet, was charged with $10.0 \mathrm{mmol}$ of diamine and $10.0 \mathrm{~mL}$ of NMP. The mixture was stirred at room temperature under nitrogen atmosphere until the solid was entirely dissolved. Then, the

solution was cooled to $0{ }^{\circ} \mathrm{C}$, had dianhydride $(10.0 \mathrm{mmol})$ added to it along with $10.0 \mathrm{ml}$ of NMP. The reaction mixture was stirred for 15 min at $0{ }^{\circ} \mathrm{C}$. Then, the temperature was raised to room temperature and left overnight. $o$-Xylene $(30 \mathrm{~mL})$ as an azeotropic agent was then added to the solution, which was stirred vigorously and heated for 6 hours at $180{ }^{\circ} \mathrm{C}$ to promote imidization. During this step, the water released by the ring-closure reaction was separated as an $o$-xylene azeotrope. The resulting brown-colored solution was cooled to room temperature, precipitated in distilled water, washed several times with water and dried in a convection oven at $120^{\circ} \mathrm{C}$ for 12 hours.

\subsubsection{Polyimide film formation}

The casting of the polyimide was done from a $15 \mathrm{wt} \%$ filtered solution in NMP onto a clean glass plate. Cast film was placed in a vacuum oven and heated slowly to $250{ }^{\circ} \mathrm{C}$ with holds for 1 hour at $100{ }^{\circ} \mathrm{C}, 150{ }^{\circ} \mathrm{C}$ and $200{ }^{\circ} \mathrm{C}$ to evaporate the solvent under high vacuum. The solid film was taken off from the glass plate, rinsed with deionized water, and dried at $120{ }^{\circ} \mathrm{C}$ until the water was removed. The defect-free and clean membranes were cut into small sized 
strips, placed between quartz plates and further heated in a muffle furnace up to $300{ }^{\circ} \mathrm{C}$, under a high-purity argon atmosphere. It was then held for 1 hour to eliminate residual solvent. Membranes with glass transition temperatures well below $300{ }^{\circ} \mathrm{C}$, were only heated up to 250 ${ }^{\circ} \mathrm{C}$ to complete solvent removal. The cooling rate of the cast membranes after annealing was $10^{\circ} \mathrm{C} / \mathrm{min}$

\subsubsection{Measurements}

${ }^{1} \mathrm{H}$ spectra were recorded on a Murcury Plus $300 \mathrm{MHz}$ spectrometer (Varian, Inc., CA, USA). Elemental analyses were performed with a Thermofinnigan EA1108 (Fisions Instrument Co., Italy) elemental analyzer. Molecular weights of precursor polyimides were measured by gel permeation chromatography (GPC, Tosoh HLC-8320 GPC, Tokyo, Japan) with a TSK ${ }^{\mathrm{TM}}$ SuperMultipore HZ-M column, and a refractive index (RI) detector in THF based on standard polystyrenes. Thermogravimetric analyses (TGAs) were performed on a TA Q-500 thermobalance (TA Instruements, DE, USA) and coupled with mass spectroscopy (MS) ThermoStar ${ }^{\mathrm{TM}}$ GSD 301T (Pfeiffer Vacuum GmbH, Asslar, Germany).

Glass transition temperatures $\left(\mathrm{T}_{\mathrm{g}}\right)$ of HPIs films were measured by differential scanning calorimetry (DSC) analyses on a TA Instruments Q20 calorimeter. A total of two heatingcooling cycles, at a heating rate of $20^{\circ} \mathrm{C} / \mathrm{min}$, were conducted and $\mathrm{T}_{\mathrm{g}}$ was obtained from the second heating cycle. Testing samples were heated to a temperature usually below the starting temperature of conversion to PBO for each HPI film during the first heating, quenched at room temperature and reheated up to $475^{\circ} \mathrm{C}$ in the second scan. Heat of decarboxylation reaction or 
rearrangement reactionoccurred around $350-450{ }^{\circ} \mathrm{C}$ for HPIs can be detected by DSC.

\subsection{Results and Discussion}

\subsubsection{Monomer synthesis}

Two ether-containing non-commercially available bis(o-aminophenol)s were synthesized in order to obtain a wider and clearer picture of how different degrees of flexibility in the nucleophilic aromatic diamine monomer can influence the thermal conversion temperature $\left(T_{T R}\right)$.

The synthesis of bis( $o$-aminophenol)s including flexible ether linkages has previously been reported [14]. The synthetic strategy usually employed in these studies involves the base mediated aromatic nucleophilic substitution of 2-hydroxy-4-fluoronitrobenzene with diverse bisphenols. This is done to provide readily the corresponding ether-containing bisnitrobenzene compound, which is further reduced to the final bis( $o$-aminophenol) by a conventional catalytic reduction in the presence of a palladium catalyst on carbon. According to this procedure, 2,2bis(4-(4-amino-3-hydroxyphenoxy)phenyl) hexafluoropropane (6FBAHPP) was synthesized successfully as reported elsewhere [14-15]. Nevertheless, in some cases, protection of the hydroxy group in the fluoronitro derivative, usually as a benzyloxy group, was proved to enhance the efficiency in the condensation step [16-18]. Thus, as a modification of this approach, the novel 1,4-bis(4-amino-3-hydroxyphenoxy)2,5-di-tert-butylbenzene (TBAHPB) monomer, including bulky di-tert-butyl side groups, was efficiently prepared from the commercially available 5-fluoronitroanisole as the starting material in the condensation 
reaction with 5-di-tert-butylhydroquinone. This was followed by demethylation of the methoxy protecting groups using pyridine hydrochloride in solvent-free conditions, and final conventional catalytic reduction with hydrazine/Pd-C (Scheme 2). Elemental analysis and ${ }^{1} \mathrm{H}$ NMR spectroscopic techniques were used to identify the structures of the intermediate compounds and the final hydroxyl diamine monomer.

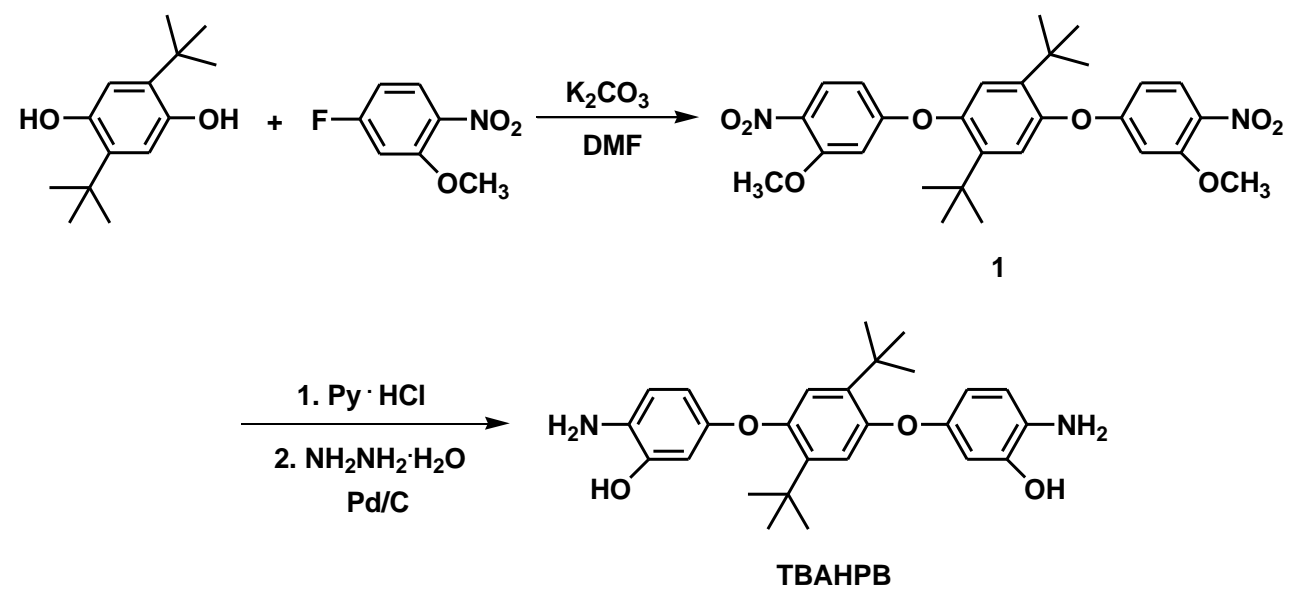

Scheme 2-2 Synthesis of 1,4-bis(4-amino-3-hydroxyphenoxy)2,5-di-tert-butylbenzene (TBAHPB).

\subsubsection{Synthesis of hydroxyl-containing precursor polyimides and copolyimides}

A series of polyimides containing hydroxy groups ortho to the imide group (HPIs) were synthesized from two commercially available bis(o-aminophenol)s monomers: the stiff biphenyl diamine 3,3'-dihydroxybenzidine (HAB), and the semi flexible diamine (APAF) containing the bulky $\left[\mathrm{C}\left(\mathrm{CF}_{3}\right)_{2}\right]$ linkage. Three commercial dianhydrides with different degrees of flexibility were also used: the rigid biphenyl BPDA dianhydride, the 6FDA dianhydride incorporating the $-\mathrm{C}\left(\mathrm{CF}_{3}\right)_{2}$ - central link, and the very flexible BPADA monomer 
containing ether and isopropylidene groups.

Moreover, new ether-containing HPIs, with a higher degree of chain mobility, were prepared based on two experimental bis(o-aminophenol)s incorporating aryl ether linkages, namely the large and highly flexible 2,2-bis(4-(4-amino-3-hydroxyphenoxy) phenyl)hexafluoropropane (6FBAHPP) that included the $\left[\mathrm{C}\left(\mathrm{CF}_{3}\right)_{2}\right]$ group as central linkage. The novel 1,4-bis(4-amino-3-hydroxyphenoxy)2,5-di-tert-butylbenzene (TBAHPB) contained bulky tert-butyl side groups in ortho positions in the central ring resulting in poly(ether-imide)s with a more contorted, rotation restricted and stiff conformation [19]. Inclusion of poly(etherimide)s will contribute to a more in depth study of the polymer structure-thermal conversion temperature relationship.

Alternatively, for further understanding of how thermal rearrangement process is affected by the chain composition and flexibility of HPI, a series of copolyimides in different ratios were also synthesized based on 6FDA and APAF comonomers including no-hydroxylated diamine moieties, such as the flexible oxydianiline (ODA) or the very rigid 2,4,6-trimethyl1,3-phenylenediamine (DAM) in different contents.

All the polymers were prepared by a two step polyimidation method using a poly(amic acid) intermediate. In the second stage, $o$-xylene as an azeotropic agent was added to the polymer solution, stirred vigorously, and heated for six hours at $180^{\circ} \mathrm{C}$ to promote imidization. During this step, the water released by the ring-closure reaction was separated as an $o$-xylene azeotrope. Structures and codes of the monomers and polymers are given in Table 2-1. The polymer nomenclature is defined by the used monomers. For example, APAF-6FDA describes 
a polyimide obtained by a reaction of APAF diamine with 6FDA dianhydride. In addition, APAF/DAM-6FDA (2:8) described a copolyimide that was prepared from 6FDA dianhydride and a mixture of APAF/DAM diamines in a ratio of 2:8. From gel permeation chromatography (GPC), it was confirmed that most of the polymers had high molecular weights (weight-average molecular weights, Mw) as shown in Table 2-1. Therefore creasable films could be prepared in every case by casting from polymer solutions. Polymer structures were confirmed by ${ }^{1} \mathrm{H}$ NMR. As an example, the ${ }^{1} \mathrm{H}$ NMR spectra of poly(ether-imide)s derived from the newly synthesized TBAHPB bis(o-aminophenol), are compiled in Figure 2-1.

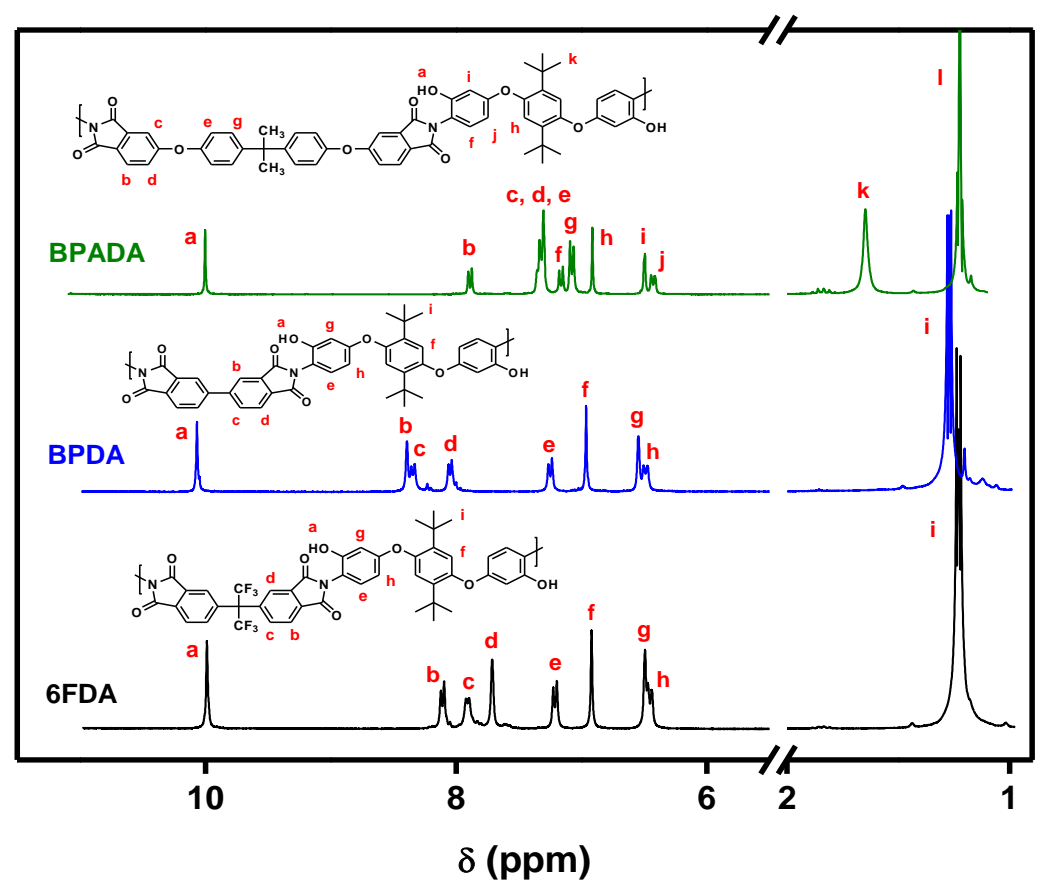

Figure 2-1 ${ }^{1} \mathrm{H}$ NMR (DMSO-d6, $300 \mathrm{MHz}$ ) spectra of TBAHPB bis(o-aminophenol) containing poly(ether-imide)s 
Table 2-1 Thermal property and Mw of hydroxyl polyimides (HPIs)

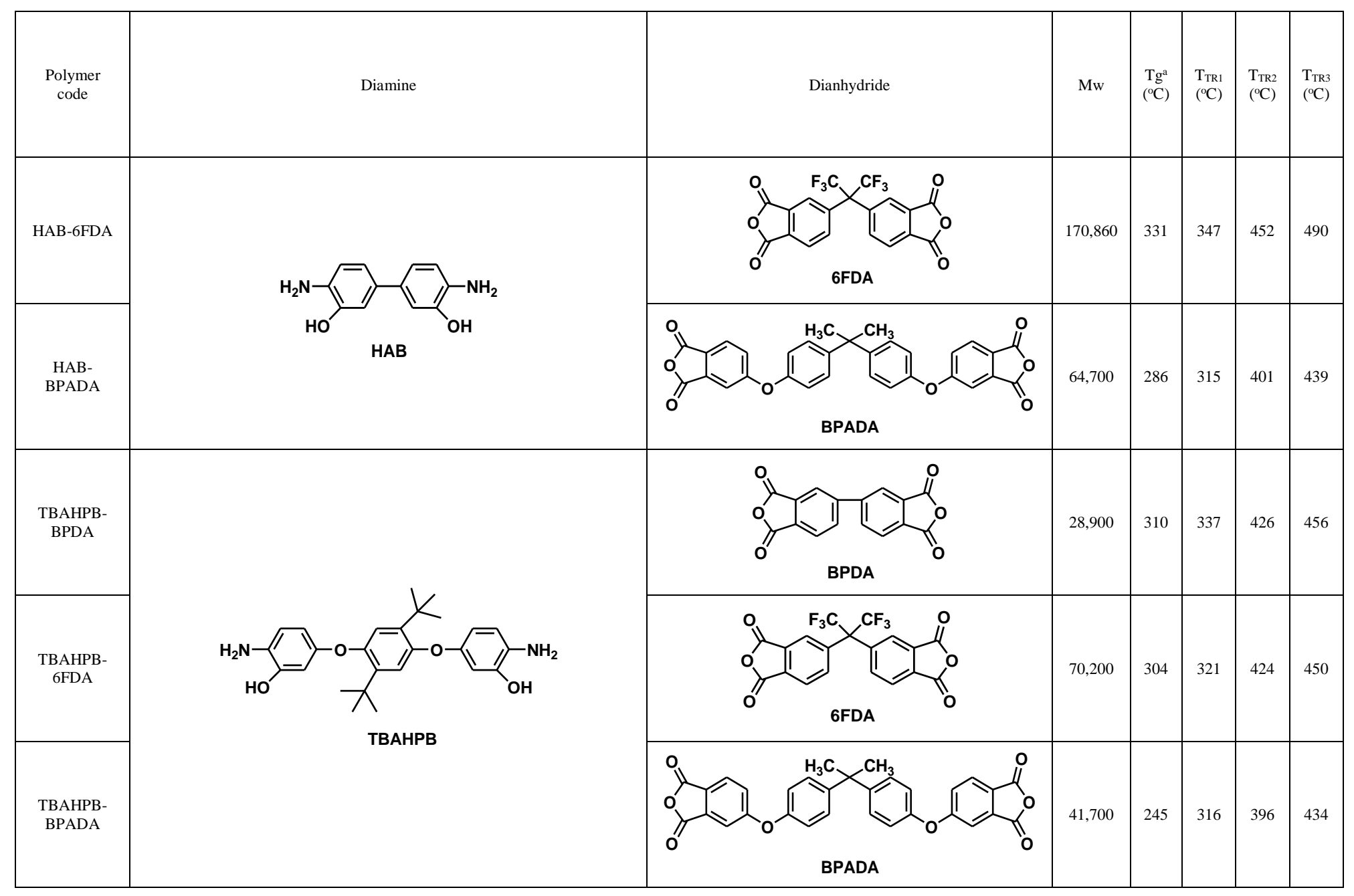




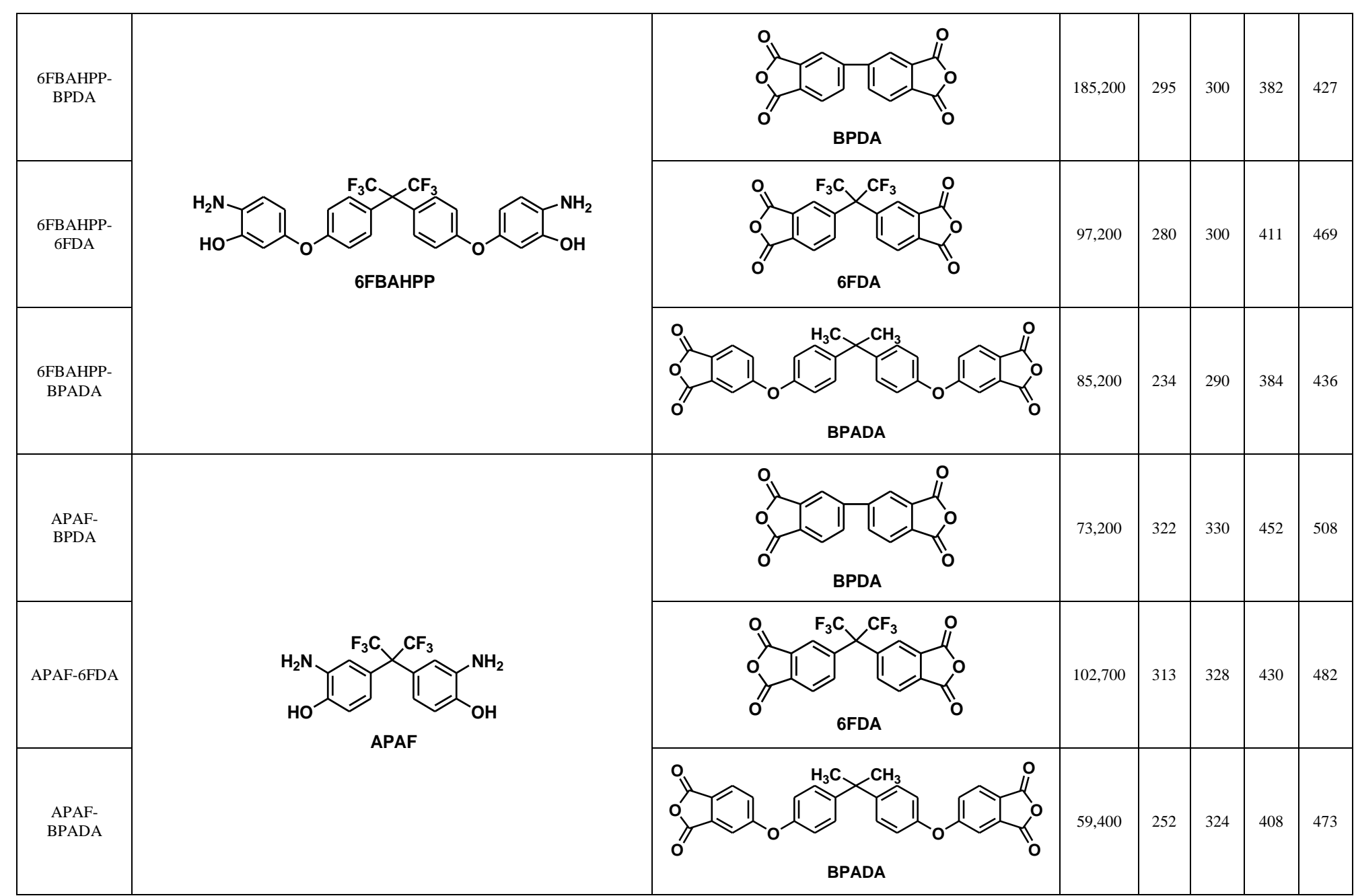




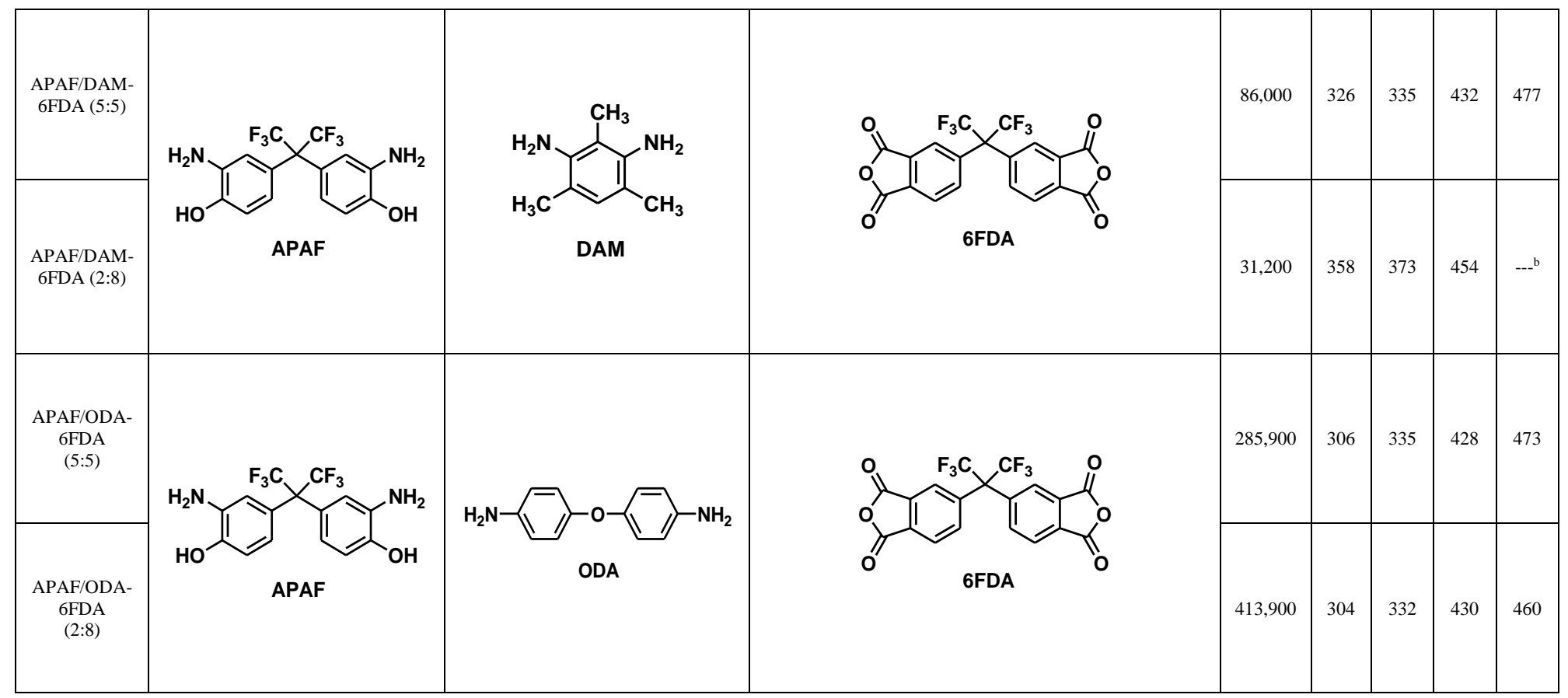

a From the second trace of DSC measurements conducted with a heating rate of $20 \mathrm{oC} /$ min under nitrogen atmosphere b Not detected 


\subsubsection{Thermal rearrangement temperature $\left(T_{T R}\right)$}

As mentioned earlier, thermal rearrangement or conversion temperature $\left(T_{T R}\right)$, is one of the crucial factors to design a cost-effective thermal treatment process for TR-PBO polymer membranes. It has been widely reported that the thermal behaviour of HPI by TGA usually shows two distinct weight losses. The first one appeared in the range of $300-500{ }^{\circ} \mathrm{C}$ corresponding to the $\mathrm{CO}_{2}$ evolved in the rearrangement to $\mathrm{PBO}$. The second one showed the generalized decomposition of the polymer backbone at around $500-600{ }^{\circ} \mathrm{C}$. Furthermore, thermogravimetric analysis coupled with mass spectroscopy (TGA-MS) provided evidence for the $\mathrm{CO}_{2}$ evolution by detection of the mass weight of $44[11,12]$. Based on these observations, we concluded that it was possible to monitor, to some extent, the thermal conversion by TGA. Thus, we have recorded TGA data for all HPIs synthesized in this work, and analyzed the thermograms in an attempt to explore the relationship between chain mobility and $\mathrm{T}_{\mathrm{g}}$ of HPI and/or $T_{T R}$.

In order to determine $T_{T R}$ by TGA, we defined three temperatures with significant changes in the first slope in the TGA curve. First, $T_{T R I}$ was the starting temperature of the weight loss defining the temperature at which polymer chains started rearranging. Second, $T_{T R 2}$ was the temperature at the maximum point of weight loss or maximum amount of $\mathrm{CO}_{2}$ evolution. Third, $T_{T R 3}$ was the temperature at the end of the weight loss and showed the end of the rearrangement process. The identification of these temperatures was carried out in the first derivative thermograms (DTG). Thus $T_{T R I}$ was analyzed from the temperature at the point where an increment in the DTG curve was detected, and $T_{T R 2}$ and $T_{T R 3}$ from the temperatures at the peak and at the end of the weight loss shown in the DTG curve. In some cases, simultaneous mass- 
spectroscopy analysis (TGA-MS) was also carried out to confirm the $\mathrm{CO}_{2}$ evolution starting point. A typical $T_{T R I} \sim T_{T R 3}$ analysis procedure is shown in Figure 2-2. A summary of $T_{T R}$ f for all polymer samples is compiled in Table 2-1.

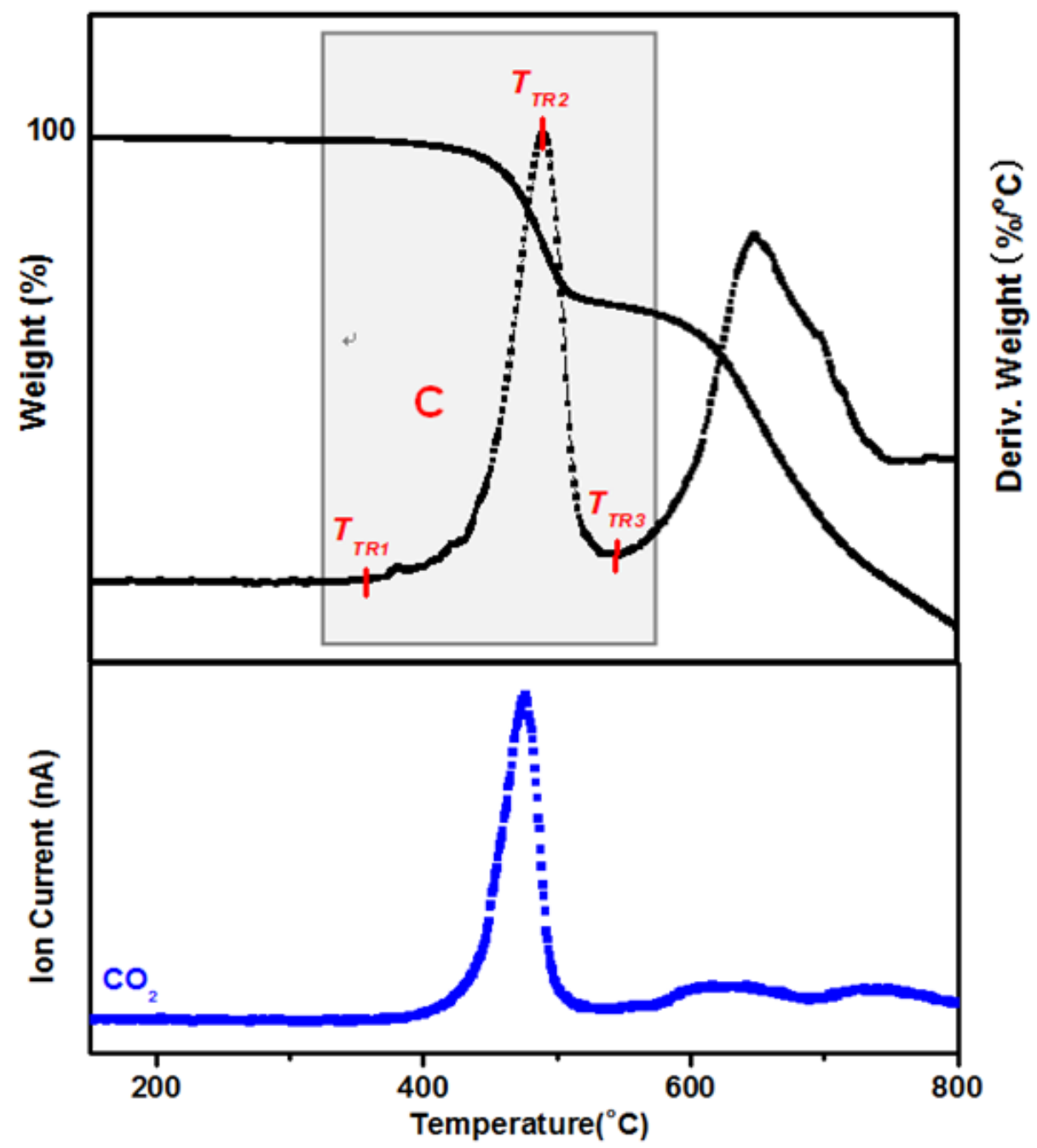

Figure 2-2 Typical TTR1 TTR3 analysis procedure in TGA and DTG curves for HAB-6FDA polyimide with mass curve of $\mathrm{CO} 2$ on the bottom 


\subsubsection{Relationship between $T_{\mathrm{g}}$ and $T_{T R}$}

We have analyzed thermal conversion temperatures $\left(T_{T R 1} \sim T_{T R 3}\right)$ for all polymers as a function of $T_{g}$ to foresee the effect of polymer structure and chain flexibility in the conversion process and for a better understanding about the relationship between $\mathrm{T}_{\mathrm{g}}$ and $T_{T R} \mathrm{~S}$.

\subsubsection{Effect of chain flexibility}

Four ortho-hydroxy diamines with different degrees of flexibility, that is, HAB, APAF, TBAHPB and 6FBAHPP, were initially considered to combine with three aromatic dianhydrides (BPDA, 6FDA and BPADA) to obtain a clear picture on how different chemical structures and rigidities in the nucleophilic $o$-hydroxy-diamine as well as in the dianhydride monomers affect $\mathrm{T}_{\mathrm{g}}$ and $T_{T R} \mathrm{~S}$ in the final precursor polyimides. The highly rigid HAB-BPDA polymer could not be synthesized by solution thermal imidization (azeotropic imidization), as were the rest of polyimides, because of premature precipitation during the imidization step.

The glass transition temperature, $T_{\mathrm{g}}$, was strongly affected by its chemical structure, as seen in Table 2-1 and Figure 2-3. For three different dianhydrides, the same trend of $\mathrm{T}_{\mathrm{g}} \mathrm{s}$ was found: HAB > APAF > TBAHPB > 6FBAHPP. The rigid biphenyl structure of diamine HAB yielded HPIs with the highest $\mathrm{T}_{\mathrm{g}}$, whilst the large and very flexible ether-containing 6FBAHPP diamine produced HPIs with the lowest $\mathrm{T}_{\mathrm{g}}$. On the other hand, polymers containing BPDA dianhydride showed higher $\mathrm{T}_{\mathrm{g}}$ than those derived from 6FDA and BPADA dianhydrides. The latter exhibited the lowest values in every case.

This trend can be clearly seen in Figure 2-3, on DSC thermograms for several of these polyimides. Note that, in most cases, $\mathrm{T}_{\mathrm{g}}$ is followed by an exothermic peak around $375-475{ }^{\circ} \mathrm{C}$, 
attributed to the intramolecular cyclization to the carboxybenzoxazole intermediate followed by decarboxylation to the final PBO [14]. Similar behavior has been observed before for some ortho-substituted aramids [20,21]. Thus, aramids containing a cyano, nitro or halogen group ortho to the amide nitrogen, undergo thermal rearrangement at high temperatures to benzoxazole polymers. This intramolecular cyclization reaction is also characterized by an exothermic transition. Pearce et al. found that the temperature range for these exothermic peaks was influenced to a certain extent by the polymer structure [21]. Note from Figure 2-3 that chemical structure also plays a role in the exothermic transitions in HPIs.

Generally, the broad exothermic peaks slightly shift towards high temperatures as $\mathrm{T}_{\mathrm{g}}$ increases, the shift being more pronounced for the most rigid polyimides, with the highest $\mathrm{T}_{\mathrm{g}}$ values. The observed enthalpy changes of the cyclodecarboxylation reaction generally ranged between 3.0 and $13.3 \mathrm{~J} / \mathrm{g}$, although in some cases (APAF-BPADA and APAF-BPDA polyimides), this enthalpy change could not be clearly analyzed (see Figure 2-3 and Table 22). HAB-6FDA polyimide, the most rigid polymer in this series $\left(\mathrm{T}_{\mathrm{g}}=331{ }^{\circ} \mathrm{C}\right)$, exhibited the largest heat flow per mass for the rearrangement reaction $(13.3 \mathrm{~J} / \mathrm{g})$. On the contrary, 6FBAHPP-BPADA polyimide, with the lowest $\mathrm{T}_{\mathrm{g}}$ value $\left(234^{\circ} \mathrm{C}\right)$, presented the smallest enthalpy change $(3.0 \mathrm{~J} / \mathrm{g})$. Hence, the most flexible BPADA containing polymers seemed to show the lowest enthalpy change as compared to 6FDA and BPDA counterparts. These results indicate that the amount of $\Delta \mathrm{H}$ at the rearrangement processs depends on the mobility of polymer chain $\left(\mathrm{T}_{\mathrm{g}}\right)$ and the weight loss during the conversion process. 


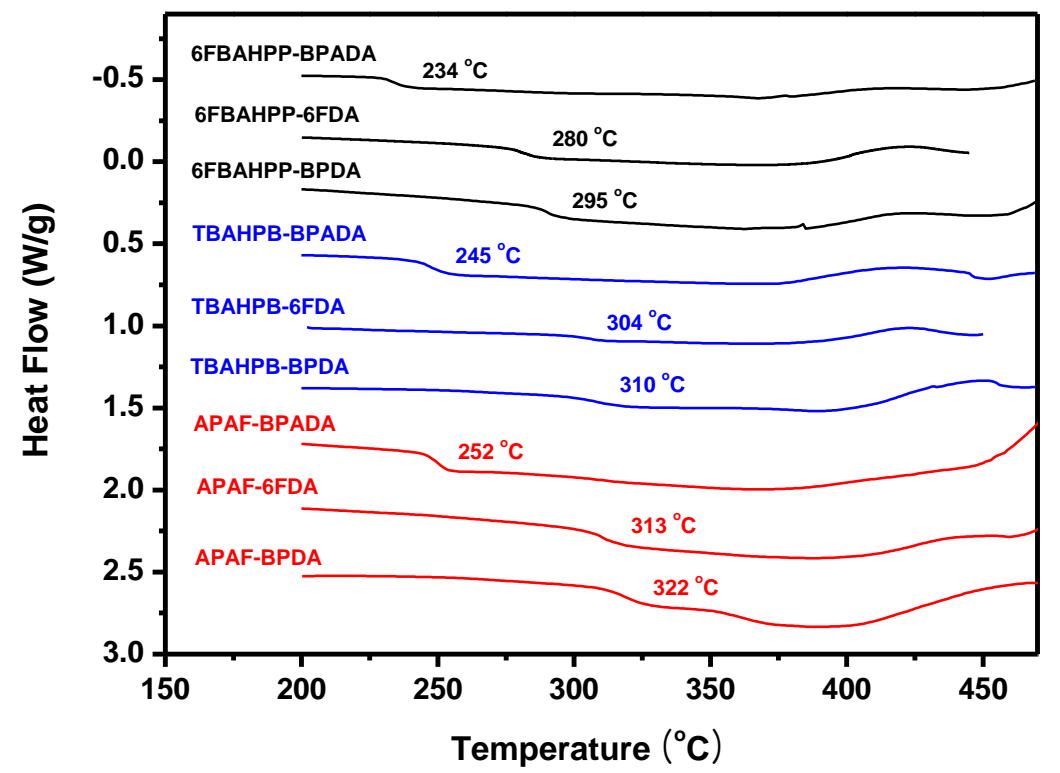

Figure 2-3 DSC curves of HPI films, at a heating rate of 20oC/min in N2, determined by the second heating scan. Glass transition temperature $\left(\mathrm{T}_{\mathrm{g}}\right)$ values are shown for nine HPIs.

These transitions are actually related to the first weight loss detected by TGA, corresponding to the evolution of $\mathrm{CO}_{2}$ during the rearrangement process as depicted in Figure 2-2. If we compare thermal conversion temperatures $\left(T_{T R I} \sim T_{T R 3}\right)$ and $T_{\mathrm{g}}$ for this set of polyimides derived from three dianhydrides BPDA, 6FDA and BPADA, respectively, it can be clearly noticed that $T_{T R} \mathrm{~S}$ are greatly affected by $\mathrm{T}_{\mathrm{g}}$. Hence, as $\mathrm{T}_{\mathrm{g}}$ increases with rigidity of dianhydride for any diamine, $T_{T R 1}, T_{T R 2}$ and $T_{T R 3}$ also move to higher temperatures. Actually, $T_{T R I} \sim T_{T R 3}$ seem to increase with $T_{\mathrm{g}}$ and are parallel to each other. For four different diamines, the same order of $T_{T R} s$ is present: BPDA $>6$ FDA $>$ BPADA. In fact, only 6FBAHPP-BPDA polymer $\left(\mathrm{T}_{\mathrm{g}}=295^{\circ} \mathrm{C}\right)$, in spite of its high $\mathrm{T}_{\mathrm{g}}$, shows a decrease in $T_{T R 2}$ and $T_{T R 3}$ in comparison 
with 6FBAHPP-6FDA counterpart $\left(\mathrm{T}_{\mathrm{g}}=280{ }^{\circ} \mathrm{C}\right)$. As an example, TGA thermograms of TBAHPB diamine containing polyimides are shown in Figure 2-4. Temperatures at the first maximum weight loss or maximum rate of $\mathrm{CO}_{2}$ evolution, $T_{T R 2} S$, are indicated as a guide. Note that, the first weight loss peak in the DTG curve clearly moves to a high temperature, as the rigidity of the dianhydride unit increases. Hence, the BPADA containing polyimide $\left(\mathrm{T}_{\mathrm{g}}=245\right.$ ${ }^{\circ} \mathrm{C}$ ) undergoes the cyclization reaction at lower temparatures than the more rigid TBAHPB6FDA $\left(\mathrm{T}_{\mathrm{g}}=304{ }^{\circ} \mathrm{C}\right)$ and TBAHPB-BPDA $\left(\mathrm{T}_{\mathrm{g}}=310^{\circ} \mathrm{C}\right)$ polyimides, although the resulting polybenzoxazoles degraded at almost the same temperature. Therefore, $T_{T R} S$ seem to be controlled by the type of dianhydride moiety. This behaviour generally agrees well with the previous findings by Likhatchev and co-workers, [1] that described a shift to low temperatures for $T_{T R I}$ and $T_{T R 2}$ when increasing flexibility of the dianhydride moiety.

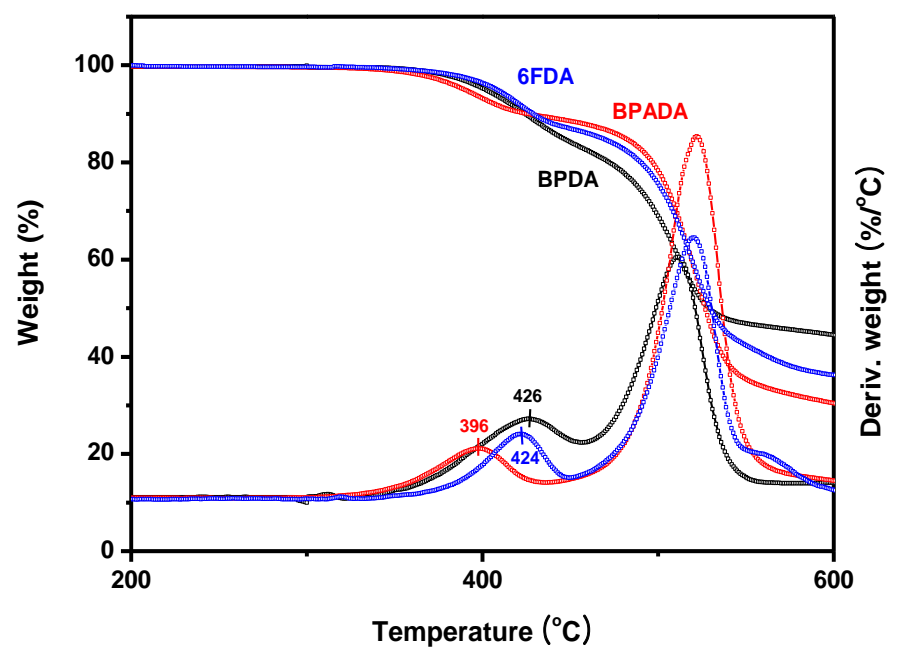

Figure 2-4 TGA and DTG curves of TBAHPB diamine containing polyimides, at a heating rate of $10 \mathrm{oC} / \mathrm{min}$ in $\mathrm{N} 2$. 
To further elucidate the relationship between chemical structure of HPI, $T_{\mathrm{g}}$ and $T_{T R} S$, the effect of different degrees of flexibility in the diamine unit was analyzed. For 6FDA containing polyimides, the shift of the starting rearrangement temperature, $T_{T R l}$, range from $304{ }^{\circ} \mathrm{C}$ for 6FBAHPP-6FDA polyimide $\left(\mathrm{T}_{\mathrm{g}}=280{ }^{\circ} \mathrm{C}\right)$, the most flexible polymer in the 6FDA series, to $347^{\circ} \mathrm{C}$ for HAB-6FDA $\left(\mathrm{T}_{\mathrm{g}}=331^{\circ} \mathrm{C}\right)$. Moreover, $T_{T R 2}$ also augments as a function of $\mathrm{T}_{\mathrm{g}}$ and is parallel to $T_{T R 1}$, in the range of $411{ }^{\circ} \mathrm{C}$ to $452{ }^{\circ} \mathrm{C}$. This trend in $T_{T R 3}$ shows a deviation for TBAHPB-6FDA polyimide, with lower $T_{T R 3}$ value than expected.

Figure 2-5 shows DTG curves of 6FDA dianhydride containing polyimides. As seen, HPI with the TBAHPB diamine presented the lowest thermal stability in the series, with degradation temperature of the resulting polybenzoxazole around $490^{\circ} \mathrm{C}$. This fact has been observed before for analogous polyimides containing di-tert-butyl side groups [20], and can be attributed to the loss of tert-butyl moieties that starts weight loss prior to the generalized degradation of the polymer chain. Unlike the rest of HPIs in the series, $T_{T R 3}$, for TBAHPB-6FDA seems to overlap with the early onset of degradation of the polymer backbone. This fact could explain the unexpected lower $T_{T R 3}$ value observed for this hydroxy-poly(ether-imide) within this series. Note that chemical structure and rigidity of diamine and dianhydride monomers seem to play a major role in the conversion from HPI to PBO. As a general trend, $T_{T R I} \sim T_{T R 3}$ shift to high temperatures as a function of increasing monomer rigidity, and thus, due to increasing $\mathrm{T}_{\mathrm{g}}$.

Hence, it was found that in every case $T_{T R 1}>\mathrm{T}_{\mathrm{g}}$, meaning that polymer chains started rearranging in the rubbery state, where sufficient free volume and adequate segmental mobility already existed for the rearrangement reaction to occur. 


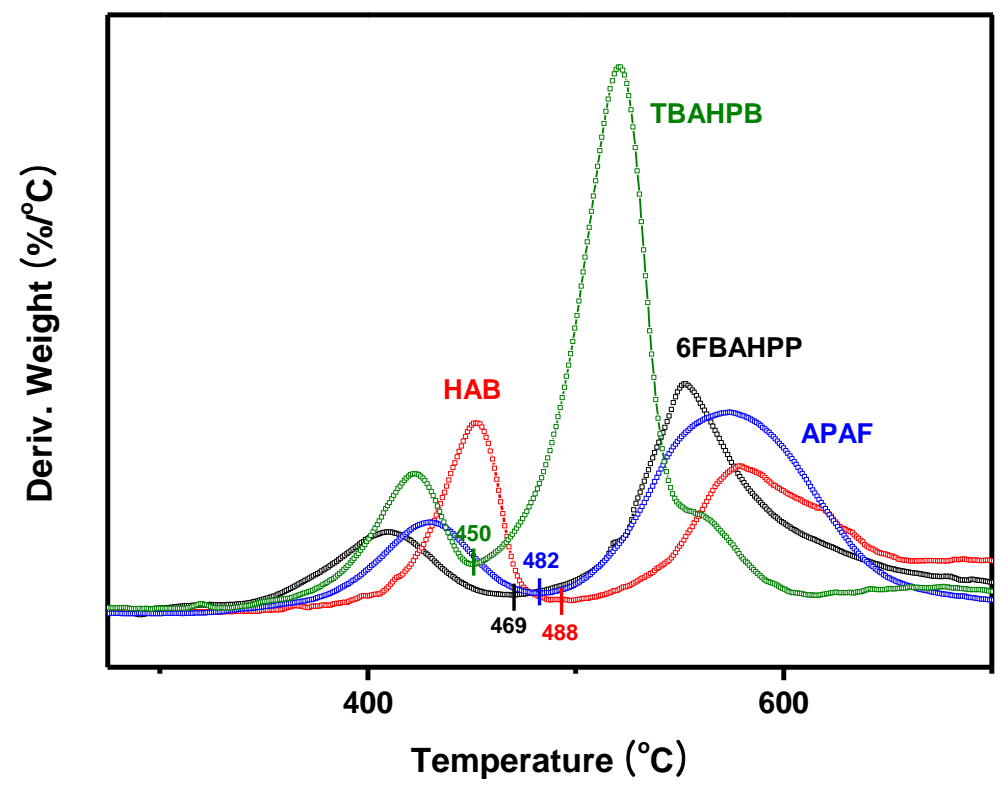

Figure 2-5 DTG curves of 6FDA dianhydride containing polyimides, at a heating rate of $10 \mathrm{oC} / \mathrm{min}$ in N2. TTR3 values are pointed out.

Another interesting fact is the range of detected $T_{T R I}$ values moving from $290{ }^{\circ} \mathrm{C}$ for the most flexible polymer, 6FBAHPP-BPADA $\left(\mathrm{T}_{\mathrm{g}}=234^{\circ} \mathrm{C}\right)$, containing ether linkages in either, diamine and dianhydride segments, to $347^{\circ} \mathrm{C}$ for the very rigid HAB-6FDA polyimide.

$T_{T R 2}$, the temperature at the maximum rate of $\mathrm{CO}_{2}$ evolution, considered to be the most effective and appropriate temperature to succesfully accomplish the rearrangement process in TR-polymers, is ranging between of 380 to $450^{\circ} \mathrm{C}$ (see Table 2-1). For a better understanding between chemical structure of HPIs and $T_{T R 2}$, we have also examined the gap between $\mathrm{T}_{\mathrm{g}}$ and $T_{T R 2}$. $T_{T R 2}-T_{\mathrm{g}}$ values usually range from 100 to $150^{\circ} \mathrm{C}$. On analyzing $T_{T R 2}-\mathrm{T}_{\mathrm{g}}$ as a function of $\mathrm{T}_{\mathrm{g}}$, it can be seen that, with few exceptions, the distance between $\mathrm{T}_{\mathrm{g}}$ and $T_{T R 2}$ increased with 
decreasing rigidity of dianhydride. HPIs with the lowest $\mathrm{T}_{\mathrm{g}}$ values within the series (6FBAHPP-BPADA, $\mathrm{T}_{\mathrm{g}}=234^{\circ} \mathrm{C}$; TBAHHPB-BPADA, $\mathrm{T}_{\mathrm{g}}=245^{\circ} \mathrm{C}$; APAF-BPADA, $\mathrm{T}_{\mathrm{g}}=$ $252^{\circ} \mathrm{C}$ ) exhibited the largest $T_{T R 2}-T_{\mathrm{g}}$ gaps. Therefore, as observed for $T_{T R 1}, T_{T R 2}$ moves along with $\mathrm{T}_{\mathrm{g}}$, and $T_{T R 2}-\mathrm{T}_{\mathrm{g}}$ increases for the most flexible polyimides in the series.

Temperature range of the rearrangement process, $\Delta T_{T R}$, determined as $T_{T R 3}-T_{T R I}$ was also considered for a more in-depth analysis of the conversion process. Large $\Delta T_{T R}$ indicates broad distribution of rearrangement process and vice versa. Nonetheless, a clear trend between $\Delta T_{T R}$ and $\mathrm{T}_{\mathrm{g}}$ does not seem to be present. Peak sharpening or broadening during $\mathrm{CO}_{2}$ evolution does not appear to be directly governed by variations in the $T_{g}$, taking place indistinctly along the polymer series.

As pointed out above, rearrangement reaction of HPIs into PBOs involves the evolution of two mol of carbon dioxide per repeat unit. Theoretical weight loss corresponding to this evolution differs for diverse polymer structures, decreasing as the molecular weight of the repeating unit increases. Hence, for the four different diamines, HPIs containing BPADA dianhydride, with the highest molecular weight per repeating unit, showed the lowest $\mathrm{CO}_{2}$ weight losses. Similarly, 6FBAHPP diamine containing HPI exhibited the smallest values for every dianydride. Table 2-2 collects the actual and theoretical $\mathrm{CO}_{2}$ weight losses for this set of HPIs. Actual weight losses, determined from the first step in the TGA curves, usually agree well with the calculated values. Observed weight loss in HPIs containing TBAHPB diamine exceeded theoretical ones, probably due to some inherent instability for this particular di-tertbutylated bis-o-aminophenol, as discussed before. 
Table 2-2 Theoretical versus found carbon dioxide weight loss (in \%) by TGA, as well as heat flow per mass ( $\mathrm{J} / \mathrm{g}$ ) by DSC (in N2), corresponding to the rearrangement reaction.

\begin{tabular}{|c|c|c|c|c|c|}
\hline $\begin{array}{c}\text { Polymer } \\
\text { code }\end{array}$ & $\mathbf{T g}\left({ }^{\circ} \mathbf{C}\right)$ & $\Delta \mathbf{H}(\mathbf{J} / \mathbf{g})$ & $\mathbf{F w}(\mathbf{g} / \mathbf{m o l})^{\mathbf{b}}$ & $\begin{array}{c}\mathbf{C O}_{2} \mathbf{w t} \text { loss } \\
\text { theoretical }\end{array}$ & $\begin{array}{c}\mathbf{C O}_{2} \mathbf{w t} \text { loss } \\
\text { found }\end{array}$ \\
\hline HAB-6FDA & 331 & 13.3 & 624.44 & 14.09 & 14.17 \\
\hline $\begin{array}{c}\text { HAB- } \\
\text { BPADA }\end{array}$ & 286 & 5.3 & 700.69 & 12.55 & 11.14 \\
\hline $\begin{array}{c}\text { TBAHPB- } \\
\text { BPDA }\end{array}$ & 310 & 8.6 & 724.8 & 12.14 & 17.01 \\
\hline $\begin{array}{c}\text { TBAHPB- } \\
\text { 6FDA }\end{array}$ & 304 & 10.8 & 874.82 & 10.06 & 13.14 \\
\hline $\begin{array}{c}\text { TBAHPB- } \\
\text { BPADA }\end{array}$ & 245 & 7.7 & 951.07 & 9.25 & 10.20 \\
\hline $\begin{array}{c}\text { 6FBAHPP- } \\
\text { BPDA }\end{array}$ & 295 & 5.3 & 808.63 & 10.88 & 10.97 \\
\hline $\begin{array}{c}\text { 6FBAHPP- } \\
\text { 6FDA }\end{array}$ & 280 & 5.5 & 958.66 & 9.18 & 9.86 \\
\hline $\begin{array}{c}\text { 6FBAHPP- } \\
\text { BPADA }\end{array}$ & 234 & 3.0 & 1034.90 & 8.5 & 7.93 \\
\hline $\begin{array}{c}\text { APAF- } \\
\text { BPDA }\end{array}$ & 322 & $-{ }^{\mathrm{a}}$ & 639.48 & 13.76 & 13.50 \\
\hline APAF-6FDA & 313 & 3.3 & 777.47 & 11.32 & 11.25 \\
\hline $\begin{array}{c}\text { APAF- } \\
\text { BPADA }\end{array}$ & 252 & $-{ }^{\mathrm{a}}$ & 850.71 & 10.34 & 13.47 \\
\hline
\end{tabular}

${ }^{a}$ Could not be analyzed from DSC thermograms

${ }^{b}$ Molecular weight of the repeating unit

\subsubsection{Effect of diamines without hydroxyl group in copolyimides}

From the findings discussed up to now, the starting conversion temperature of the imideto-benzoxazole, $T_{T R I}$, as well as the maximum rate of reaction $\left(T_{T R 2}\right)$ and the final reaction temperature $\left(T_{T R 3}\right)$, seem to be controlled by the type of dianhydride and diamine monomers. In order to better understand the relationship between chemical structure, $T_{\mathrm{g}}$ and $T_{T R}$, we intentionally attempted to change flexibility of HPI precursor while retaining chemical structure of the monomers involved in the rearrangement process by copolymerization with two different diamines without hydroxyl groups, namely, the highly stiff tri-methylated DAM diamine, and the quite flexible ether-containing oxydianiline (ODA). Thus, by incorporating 
DAM into the APAF-6FDA structure, the rigidity of the polymer backbone increased. Two copolyimides with APAF and DAM diamines with molar ratios of 5:5 and 2:8 were prepared. Thus, $\mathrm{T}_{\mathrm{g}}$ for this series of copolymers increased gradually with increasing mol fraction of DAM (see Table 2-1). Figure 2-6 exhibits TGA and DTG curves of this APAF/DAM-6FDA series. As seen, the first peak due to the $\mathrm{CO}_{2}$ evolution during the conversion process, shifts to high temperatures as the mol fraction of the more rigid comonomer DAM increases. For the most rigid composition with the highest $\mathrm{T}_{\mathrm{g}}$ value, (APAF/DAM-6FDA $\left.(2: 8), \mathrm{T}_{\mathrm{g}}=358^{\circ} \mathrm{C}\right), T_{T R 3}$ becomes imperceptible, reaching the onset of generalized decomposition of the polymer backbone, around $500{ }^{\circ} \mathrm{C}$.

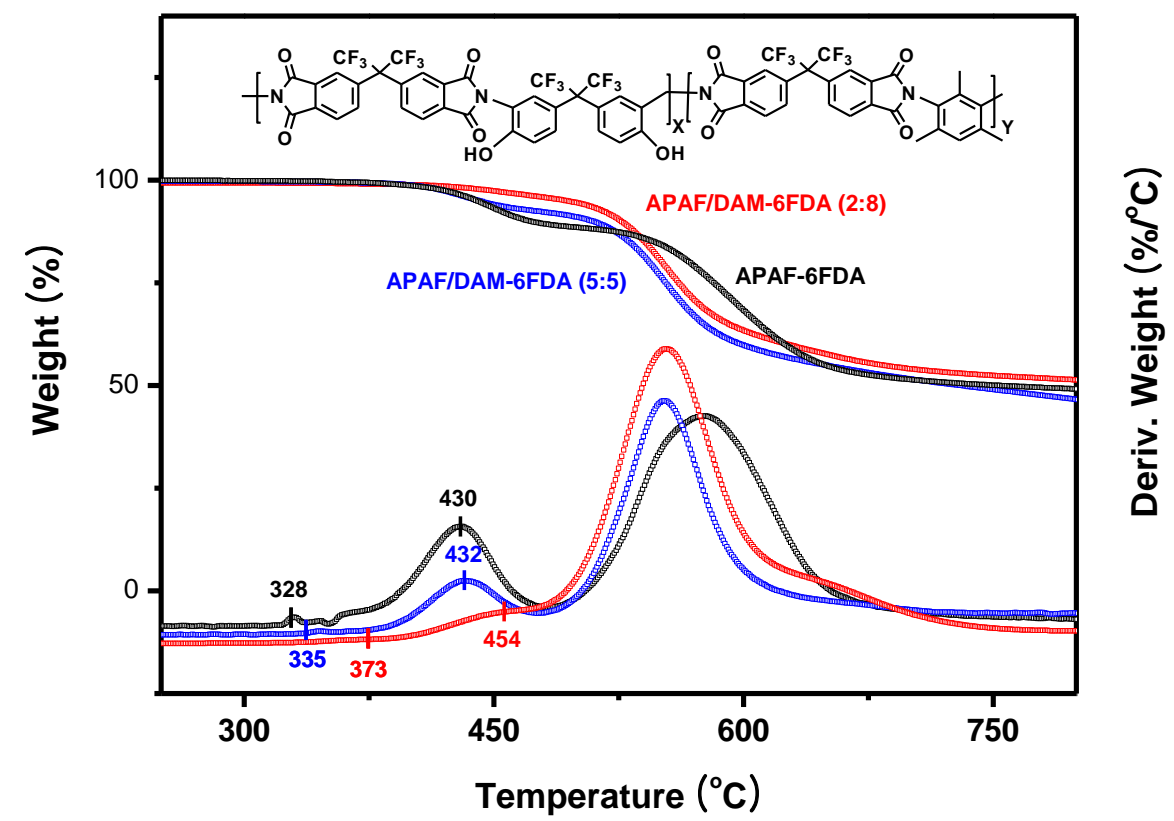

Figure 2-6 TGA and DTG curves for APAF/DAM-6FDA series of co-polyimides. 
By incorporating a more flexible diamine such as ODA in HPI, we expected to improve polymer chain mobility, and thus to decrease $\mathrm{T}_{\mathrm{g}}$. In fact, $\mathrm{T}_{\mathrm{g}}$ dropped from $313{ }^{\circ} \mathrm{C}$ for APAF6FDA homopolymer to $306^{\circ} \mathrm{C}$ for APAF/ODA-6FDA (5:5) and remained almost constant when further augmenting ODA diamine content up to $80 \%\left(\mathrm{~T}_{\mathrm{g}}=304^{\circ} \mathrm{C}\right)$, which was the same as ODA-6FDA homopolymer [22]. From these observations, it is difficult to recognize a trend, as the chain ridigity might not be the only factor affecting $\mathrm{T}_{\mathrm{g}}$. As was expected, these minor variations in $\mathrm{T}_{\mathrm{g}}$ for this series of ODA copolyimides, did not have significant repercussions on conversion temperatures to $\mathrm{PBO}$, and thus, $T_{T R I} \sim T_{T R 3}$ values of this copolymers scarcely changed with $\mathrm{T}_{\mathrm{g}}$. TGA and DTG curves for APAF/ODA-6FDA series clearly show this behaviour (Figure 2-7).

Notice that $T_{T R I} \sim T_{T R 3}$ of HPIs, regardless of the presence of rigid DAM diamine are influenced by the changes in flexibility, $\mathrm{T}_{\mathrm{g}}$, In addition, it is obvious that the addition of comonomer such as ODA in HPIs does not dignificantly alter the $\mathrm{T}_{\mathrm{g}}$ of HPIs and thus TTR remains relatively unchanged for these polymers.

To attain a complete and general picture on how $\mathrm{T}_{\mathrm{g}}$ of HPI and conversion to PBO temperature are related to each other, $T_{T R I} \sim T_{T R 3}$ versus $\mathrm{T}_{\mathrm{g}}$ for all the $o$-hydroxypolyimides described in this work, have been plotted in Figure 2-8. In this figure, $T_{T R I} \sim T_{T R 3}$ and $\mathrm{T}_{\mathrm{g}}$ generally show a linear relationship, signifying that as $T_{\mathrm{g}}$ increases, $T_{T R I} \sim T_{T R 3}$ increase linearly. 


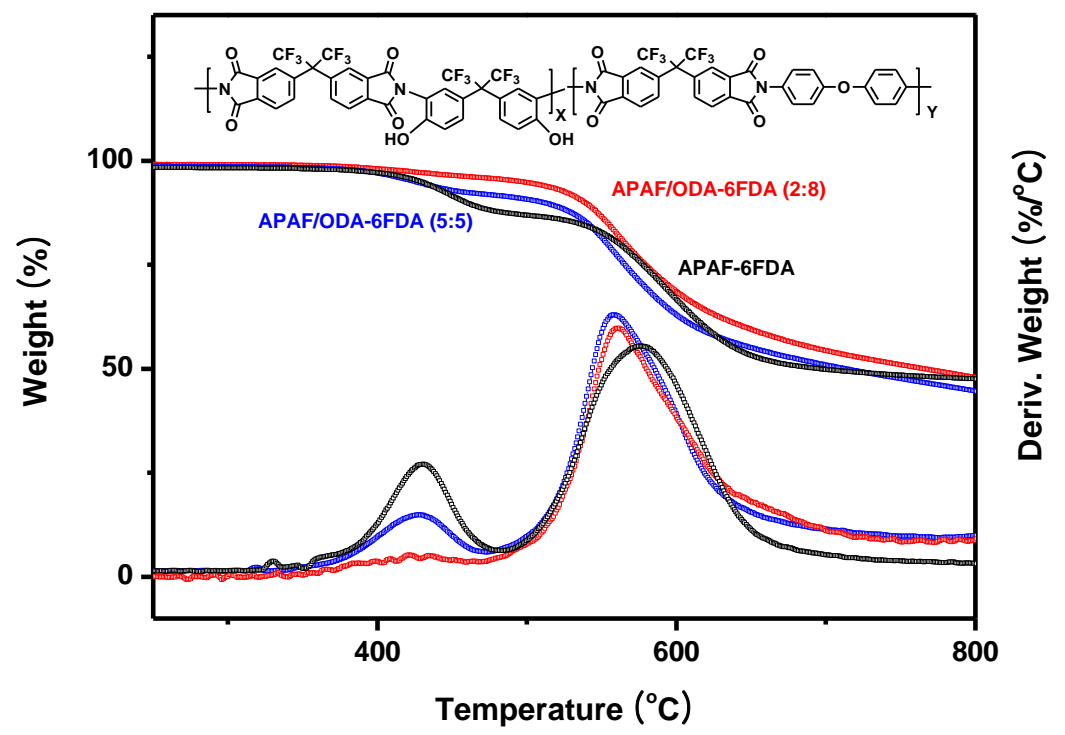

Figure 2-7 TGA and DTG curves for APAF/ODA-6FDA series of co-polyimides.

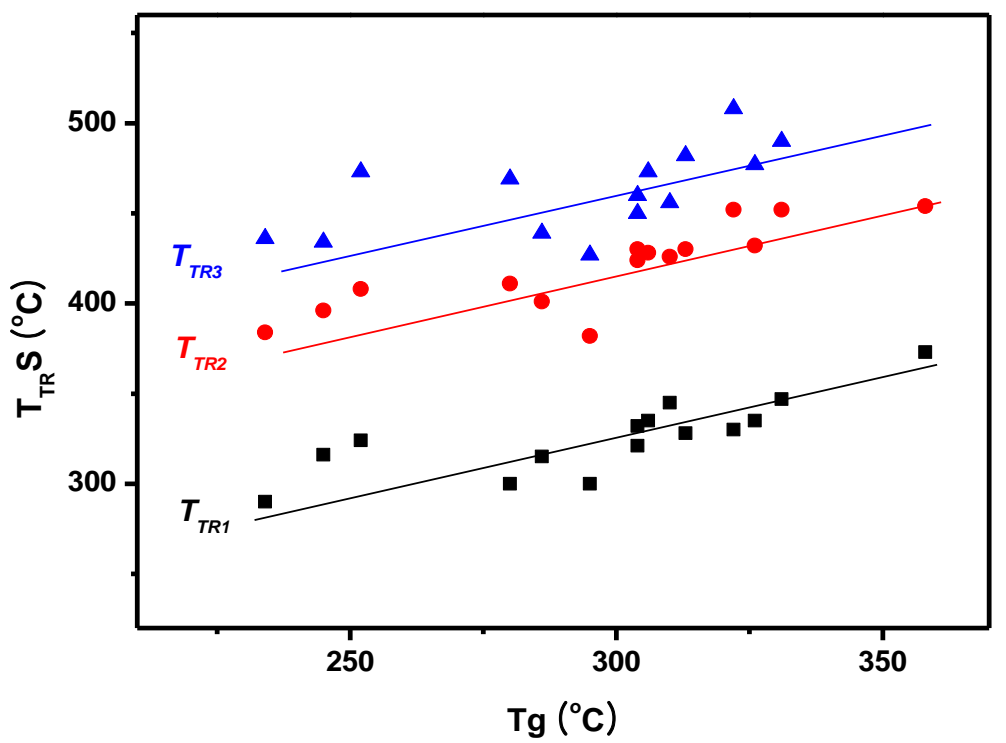

Figure 2-8 TTRs values as a function of $\mathrm{T}_{\mathrm{g}}$ for 15 o-hydroxypolyimides and ohydroxycopolyimides. 


\subsection{Conclusions}

Upon analyzing DSC and TGA data for a total of 15 sets of $o$-hydroxypolyimides and copolyimides derived from two experimental and four commercial structurally different diamines, as well as three different dianhydrides monomers, we have attempted to elucidate the relationship between glass transition $\left(\mathrm{T}_{\mathrm{g}}\right)$ of the precursor hydroxy-polyimide and the conversion temperature to polybenzoxazole in film samples. Thus, thermal rearrangement temperature, defined as $T_{T R I}$, conversion starting temperature of the imide-to-benzoxazole, and $T_{T R 2}$ and $T_{T R 3}$, the maximum rate of reaction and the end of the rearrangement process temperatures, respectively, showed dependence with $T_{\mathrm{g}}$ of HPIs. In fact, $T_{T R I} \sim T_{T R 3}$ seemed to be influenced by the type of dianhydride and diamine monomers. Heat flow during the thermal rearrangement detected by DSC showed relationship with $\mathrm{T}_{\mathrm{g}}$, but was not as clear as $T_{T R} S$ detected by TGA. It is found that chain rigidity of HPI influences the thermal conversion temperature to polybenzoxazole, which should be considered when studying TR polymers. 


\section{References}

[1] Likhatchev D, Gutierrez-Wing C, Kardash I, Vera-Graziano R. J. Appl. Polym. Sci. 1996;59:725-735.

[2] Tullos GL, Mathias L. J. Polym. 1999;40:3463-3468.

[3] Tullos GL, Powers JM, Jeskey SJ, Mathias LJ. Macromolecules 1999;32:3598-3612.

[4] Guzman-Lucero D, Likhatchev D. Polym. Bullet. 2002;48:261-269.

[5] Schab-Balcerzak E, Jikei M, Kakimoto M. Polym. J. 2003;35:208-212.

[6] Chen BK, Tsai YJ, Tsay SY. Polym. Int. 2006;55:93-100.

[7] Okabe T, Morikawa A. High Perform. Polymer. 2008;20:53-66.

[8] Park HB, Jung CH, Lee YM, Hill AJ, Pas SJ, Mudie, ST, Wagner EV, Freeman BD, Cookson DJ. Science 2007;318:254-258.

[9] Choi JI, Jung CH, Han SH, Park HB, Lee YM. J. Membr. Sci. 2010;349:358-368.

[10] Jung CH, Lee JE, Han SH, Park HB, Lee YM. J. Membr. Sci. 2010;350:301-309.

[11] Park HB, Han SH, Jung CH, Lee YM, Hill AJ. J. Membr. Sci. 2010;359:11-24.

[12] Han SH, Misdan N, Kim S, Doherty, CM, Hill, AJ, Lee YM, Macromolecules 2010;43:7657-7667.

[13] Kim SJ, Han SH, Lee YM, J. Membr. Sci 2012; doi:10.1016/j.memsci.2012.02.041

[14] Calle M, Lee YM. Macromolecules 2011;43:7657-7667.

[15] Chern, Y.T.; U.S. Patent 2006;2006/0241187.

[16] Park KH, Kakimoto M, Imai Y. J. Polym. Sci. Part A: Polym. Chem. 1998;36:1987-1994.

[17] Imai Y, Maeda Y, Takeuchi H, Park KH, Kakimoto MA, Kurosaki T. J. Polym. Sci. Part A: Polym. Chem. 2002;40:2656-2662.

[18] Imai Y, Shibasaki Y, Takeuchi H, Park KH, Kakimoto MA. High Performance Polymers 
2002;14:253-260.

[19] Calle M, Lozano AE, de Abajo J, de la Campa JG, Alvarez C. J. Membr. Sci 2010; 365:145-153.

[20] Kim S, Pearce EM, Kwei TK. Polymer for Advanced Technologies 1989; 1:49-73.

[21] Kim S, Pearce EM 1989; 15:187-218.

[22] Kamaruddin HD, Koros WJ. J. Polym. Sci. Part. B: Polym. Phys. 2000;38:2254-2267. 


\section{$\underline{\text { Chapter } 3}$}

\section{Thermally Rearranged Poly(benzoxazole-co-imide) Membranes with Superior Mechanical Strength for Gas Separation Obtained by Tuning Chain Rigidity}

This paper has been published as: H.J. Jo, C.Y. Soo, G. Dong, Y.S. Do, H.H. Wang, M.J. Lee, J.R. Quay, M.K. Murphy, Y.M. Lee, Thermally Rearranged Poly(benzoxazole-co-imide) Membranes with Superior Mechanical Strength for Gas Separation Obtained by Tuning Chain Rigidity, Macromolecules, 48 (2015) 21942202. 


\subsection{Introduction}

Development of micro-porous polymer membranes has been an active research area for the past few decades, especially in the industrial gas separation field $\left(\mathrm{CO}_{2}\right.$ capture from postcombustion flue gas in particular), where only highly permeable membranes can ensure separation productivity and efficiency [1-3]. Research efforts have focused mainly on the synthesis of polymer materials with micro-porous cavities and high fractional free volume (FFV), such as poly(trimethylsilyl-1-propyne) (PTMSP)[4], perfluoropolymers[5], fully aromatic and cross-linked thermally rearranged (TR) polymers with rigid main structures[616], polymers with intrinsic micro-porosity (PIM) containing ladder-like structures with kinked groups[17-22], and Tröger's base polymers[23-28]. More recently, attempts have been made to combine the benefits of different types of polymers, for example TR-PIM polymers [29,30] and Tröger's base PIM [31]. All the aforementioned polymers have been developed by following the strategy of enhancing the polymer chain stiffness and backbone rigidity, thus not only boosting gas permeability and selectivity, but also promoting performance sustainability by restricting chain movement and packing [32]. Membranes fabricated from these polymer materials exhibited exceptional gas transport behavior and exceeded the so-called permeability-selectivity trade-off relation discovered by Robeson and colleagues [33,34].

In terms of advances in TR polymers, research efforts have focused on improving separation performance, processability, and thermal/chemical stability through: (i) optimization of thermal treatment protocols $[10,15]$, (ii) investigation of various precursor polymerization routes and their influences on FFV, thermal conversion behavior, and gas transport properties[9, 12, 13], and (iii) manipulation of cavity size and distribution of the 
thermally rearranged polybenzoxazoles (TR-PBOs)[11, 14, 30, 35] More recently, research interest has focused on the fabrication of TR-PBO membranes with an industry-preferred hollow fiber geometry using poly(amic acid) (PAA) as precursor[36].

However, the fragility and brittleness of TR-PBO membranes still remain a major challenge for large-scale industry implementation of such membranes. Research efforts have therefore shifted to improving the mechanical properties of TR-PBO membranes, and the following strategies have been proposed: (i) introducing spirobisindane with a kinked structure in the TR-PBO membrane to disrupt the chain packing density, thus enhancing the mechanical strength of the membranes[30, 32], and (ii) incorporating polyimide (PI) in TR-PBO to produce polybenzoxazole-co-imide (TR-PBOI) membranes [37, 38].

The discovery of a strong correlation between the ratio of TR-able and non-TR-able diamines and membrane micro-structure, as well as the gas permeability of the resultant membranes by Jung et al. represents another approach to manipulate the morphological and transport properties of TR-polymer membranes [40]. Soo et al. extended this work further by evaluating the effect of the chemical structure of non-TR-able diamines (e.g. the presence of bulky side groups or flexible ether linkages) on the physical properties of the membranes as well as their separation performance [41]. Recently, the synthesis of hydroxyl copolyimides incorporating a rigid non-TR-able diamine moiety through the chemical imidization method was studied in the context of gas separation, and the effects of different ratios of PBO to PI and the type of non-TR-able moiety were investigated [39].

Despite all these efforts, a thorough understanding of the functionality of non-TR-able 
diamines, especially with respect to their interactions with TR-able components and their impact on membrane chemico-physical properties, is still lacking. In addition, the formation of FFV and the size of cavities in TR-PBOI membranes are greatly influenced by the choice of synthesis route. ${ }^{9}$ This motivated our comprehensive investigation of two commercially available TR-able diamine monomers, namely 2,2'-bis(3-amino-4-hydroxyphenyl) hexafluoropropane (bisAPAF) and 3,3'-dihydroxyl-4,4'-diamino-sbiphenyl (HAB), and two common non-TR-able diamine monomers, namely 2,4,6-Trimethyl-m-phylenediamine (DAM) and 4,4'-oxydiamine (ODA), as monomers for membrane fabrication. We assessed the chemico-physical and gas separation properties of membranes synthesized with various ratios of the above precursors by characterizing a wide variety of membrane properties (e.g. glass transition temperature, thermal rearrangement temperature, fractional free volume, tensile strength, elongation at break, gas permeability, and ideal selectivity). We provided an in-depth discussion of the structure-property relationships of TR-PBOI membranes to highlight the interactions between non-TR-able and TR-able diamines and their influence on membrane properties. We also established an optimal synthesis approach to produce TR-PBOI membranes with both excellent mechanical strength and superior separation properties.

\subsection{Experimental Section}

\subsubsection{Materials.}

4,4'-(hexafluoroisopropylidene) diphthalic anhydride (6FDA) was purchased from Daikin Industries, Ltd. (Osaka, Japan). TR-able diamines included 2,2'-bis(3-amino-4-hydroxyphenyl) 
hexafluoropropane (bisAPAF) from Central Glass Co. Ltd. (Tokyo, Japan) and 3,3'dihydroxyl-4,4'-diamino-biphenyl (HAB) from Wakayama Seika Kogyo Co., Ltd. (Wakayama, Japan). Non-TR-able diamines used in this study were 4,4'-oxydiamine (ODA) from Tokyo Chemical Industry (TCI) CO., Ltd. (Tokyo, Japan) and 2,4,6-Trimethyl-m-phylenediamine (DAM) from Chemtec (China, sublimed twice and stored under argon). 6FDA was dried in a vacuum oven at $100^{\circ} \mathrm{C}$ for at least 24 hours. BisAPAF, $\mathrm{HAB}$, and ODA were stored in a vacuum chamber at $40^{\circ} \mathrm{C}$ prior to the reaction. $\mathrm{N}$-methyl-2- pyrrolidone (NMP) and $o$-xylene were purchased from Sigma-Aldrich Co. LLC (St. Louis, USA) and used without further purification.

\subsubsection{Polymer synthesis and membrane fabrication.}

Four different series of copolymers based on 6FDA with varied compositions of TR-able hydroxyl diamines (bisAPAF and HAB) and non-TR-able diamines (DAM and ODA) were prepared. Precursor hydroxyl copolyimides were synthesized following the azeotropic imidization method. Three $250 \mathrm{ml}$ four-neck round-bottomed flasks with different ratios of hydroxyl diamine and diamine (4:16 mmol, 10:10 mmol, and 16:4 mmol) were prepared and washed with $35 \mathrm{ml}$ NMP. Once all the monomers were completely dissolved, 6FDA (20 mmol) was added to the flask. The reaction mixture was stirred for 12 hours at $15^{\circ} \mathrm{C}$ to obtain hydroxyl copoly(amic acid).

Imidization was conducted at $180^{\circ} \mathrm{C}$ for 6 hour by $O$-xylene reflux in a Dean-stack trap equipped flask. The crude solution was precipitated in a methanol/water (1:3) mixture and washed with de-ionized water three times to remove NMP and $o$-xylene. The obtained 
polymers were then dried in a vacuum oven at $150^{\circ} \mathrm{C}$ for more than 12 hours. HPI and PI membranes were prepared according to the following protocol. Completely dried polymers (15 wt \%) were dissolved in NMP and cast on a glass plate, then slowly heated up to $250^{\circ} \mathrm{C}$. After the solvent was evaporated, the thickness of the obtained hydroxyl copolyimide membranes was around $50 \mu \mathrm{m}$. TR-PBO and TR-PBOI membranes were prepared by heating the precursor membranes in a muffle furnace at $400^{\circ} \mathrm{C}$ for 2 hours that was purged with $300 \mathrm{cc} / \mathrm{min}$ high purity argon (Scheme 1).
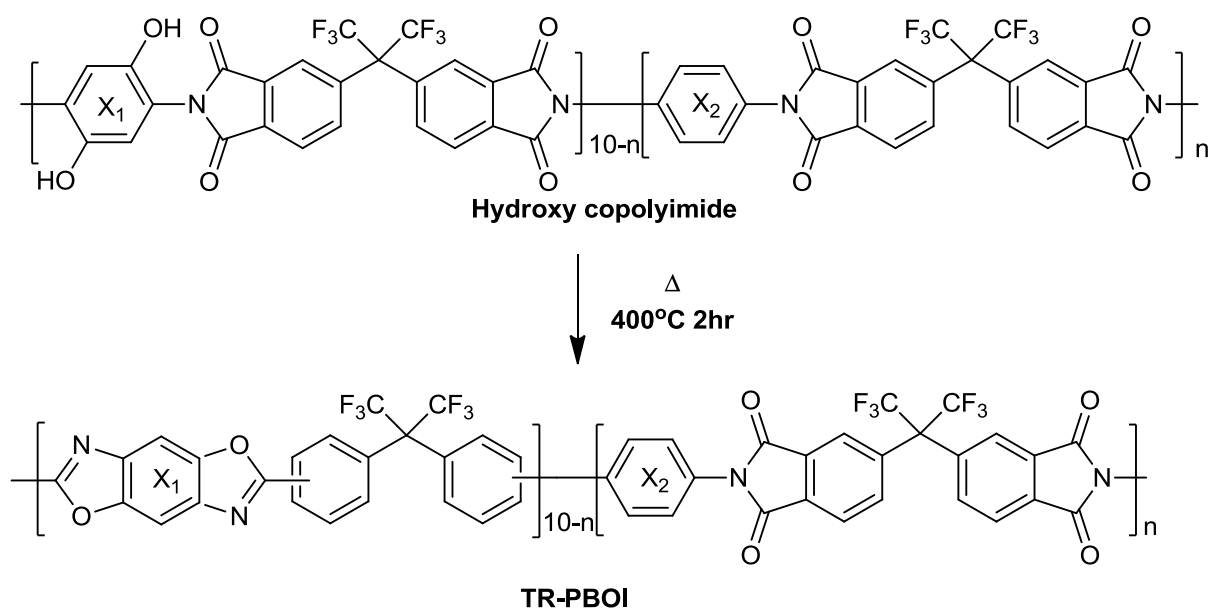

TR-able diamines
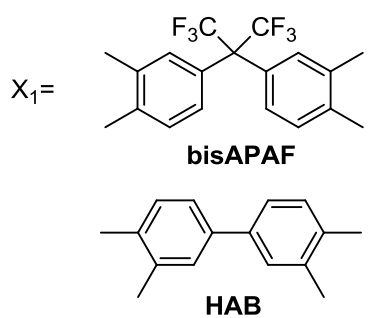

non TR-able diamines<smiles>[Y]#[X]c1cc(C)c(C)c(C)c1C</smiles><smiles>Cc1cccc(Oc2cccc([N+](=O)[O-])c2)c1</smiles>

Scheme 3-1 Chemical structures and compositions of the diamines, hydroxyl copolyimide, and TR-PBOI membranes. (n) and (10-n) refer to the molar ratio of PBO derived from TR-able diamines (bisAPAF or HAB) and PI containing non-TR-able diamines (DAM or ODA). 


\subsubsection{Characterization.}

The physical properties of the copolyimides and TR-PBOI membranes were measured using several characterization techniques. The molecular weight of the HPIs was evaluated using gel permeation chromatography (GPC, TosohHLC-8320GPC, Seoul, Korea) with a TSKTM Super Multi pore HZ-M column and a refractive index (RI) detector in THF on the basis of standard polystyrenes. FFV was calculated based on Bondi's group contribution theory. ${ }^{42,} 43$ The thermal rearrangement study was conducted using a thermo gravimetric analyzer (TGAQ500, TA Instruments, New Castle, DE, USA) and Fourier-transformation infrared spectroscopy (FT-IR, Nicolet6700, Thermo Fisher Scientific Inc., MA, USA) to confirm the formation of benzoxazole. The glass transition temperature $\left(T_{g}\right)$ of the HPIs was determined using a dynamic mechanical analyzer (DMAQ800, TA Instruments). Tensile strength and elongation at break of the TR-PBOI and TR-PBO membranes were measured using a universal test machine (Autograph AGS-J, Shimadzu, Kyoto, Japan) and specimens were prepared according to the international standard (ASTM-D638). BET surface area and sorption characteristics were measured at $77 \mathrm{~K}$ by a surface area and porosimetry analyzer (ASAP2020, Micrometric Instruments Corp., Norcross, GA, USA).

The density of the precursors and TR-PBOI membranes was measured using an electronic balance equipped with a density kit (Sartorius, Gottingen, Germany) utilizing the buoyancy method, in which the weight of a membrane was measured in air and then in 2,2,4trimethylpentane. The density was then calculated using the following equation:

$$
\rho_{m}=\frac{w_{\text {air }}}{w_{\text {air }}-w_{l}} \rho_{l}
$$


where $\rho_{m}\left(\mathrm{~g} / \mathrm{cm}^{3}\right)$ is the density of the membrane, $w_{\text {air }}(\mathrm{g})$ is the weight of the membrane in air, $w_{l}(\mathrm{~g})$ is the weight of the membrane in 2,2,4-trimethylpentane, and $\rho_{l}\left(\mathrm{~g} / \mathrm{cm}^{3}\right)$ is the density of the membrane in 2,2,4-trimethylpentane.

Percentage conversion was calculated by TGA-isotherm analysis. Actual weight loss due to the release of $\mathrm{CO}_{2}$ during thermal rearrangement was measured by TGA-isotherm. The percentage conversion is the ratio of the actual weight loss divided by the theoretical mass loss as shown below: ${ }^{15,41}$

$$
\% C_{T G A}=\frac{\text { Actual mass loss }(\%)}{\text { Theoritical mass loss (\%) }}
$$

Fractional free volume (FFV) of all membranes, including precursors, was obtained from the equation below:

$$
F F V=\frac{V_{s p}-1.3 V_{w}}{V_{s p}}
$$

where $V_{s p}\left(\mathrm{~cm}^{3} / \mathrm{g}\right)$ is the specific volume, which is the inverse value of density, and $V_{w}$ $\left(\mathrm{cm}^{3} / \mathrm{g}\right)$ is the Van der Waals volume derived from Bondi's group contribution theory. ${ }^{42,}{ }^{43}$ To estimate the FFV of TR-PBOI membranes, the value of $V_{w}$ should be carefully considered in cases where the percentage conversion is less than $100 \%$. The $V_{w}$ of TR-PBOI was obtained by the equation shown below considering the molar ratio of TR-able and non-TR-able diamines and the percentage conversion of each membrane: ${ }^{41}$ 


$$
V_{w}=(1-r)\left(V_{w, n o n T R}\right)+r\left[V_{w, P B O}\left(\frac{C}{100}\right)+V_{w, H P I}\left(1-\frac{C}{100}\right)\right]
$$

Here $C$ is the percentage conversion, $r$ is the molar ratio of TR-able diamine, and (1-r) is the molar ratio of non-TR-able diamine.

Pure gas permeability and ideal selectivity were measured by the time-lag method in an oven chamber equipped with a constant downstream volume at $35^{\circ} \mathrm{C}$ with high purity single gases ( $\left.\mathrm{He}, \mathrm{H}_{2}, \mathrm{O}_{2}, \mathrm{~N}_{2}, \mathrm{CO}_{2}, \mathrm{CH}_{4}\right)$, and calculated based on the equations below:

$$
\begin{gathered}
\mathrm{P}=\mathrm{D} \cdot \mathrm{S}=\left(\frac{V T_{0} l}{P_{0} T A \Delta P}\right) \frac{d p}{d t} \\
\alpha=\frac{\mathrm{P}_{1}}{\mathrm{P}_{2}}
\end{gathered}
$$

$\mathrm{P}$ (Barrer) is the pure gas permeability and is the product of gas diffusivity $\mathrm{D}\left(\mathrm{cm}^{2} / \mathrm{s}\right)$ and solubility $\mathrm{S}\left(\mathrm{cm}^{3}(\mathrm{STP}) / \mathrm{cm}^{3} \mathrm{cmHg}\right)$ according to the solution-diffusion model. $V\left(\mathrm{~cm}^{3}\right)$ is the downstream volume in the oven chamber, $T_{0}(\mathrm{~K})$ and $P_{0}(\mathrm{cmHg})$ are the standard temperature and pressure, respectively, $l(\mathrm{~cm})$ is the thickness of the membrane, $A\left(\mathrm{~cm}^{2}\right)$ is the effective area of the membrane, and $\Delta P$ is the pressure difference between the upstream and downstream of the membrane. $d P / d t(\mathrm{cmHg} / \mathrm{s})$ is the rate of pressure rise in the downstream volume at steady state. 


\subsection{Results and Discussion}

\subsubsection{Physical properties of precursor hydroxyl copolyimides and thermal rearrangement to TR-PBOIs.}

The major physical properties of the precursor hydroxyl copolyimide membranes (e.g. molecular weight, glass transition temperature, and fractional free volume) were measured and are presented in Table 3-1. Four series of hydroxyl copolyimides (APAF-DAM, APAF-ODA, HAB-DAM, and HAB-ODA) with a number-average molecular weight $\left(\mathrm{M}_{\mathrm{n}}\right)$ higher than $10,000 \mathrm{kgmol}^{-1}$ and weight-average molecular weight $\left(\mathrm{M}_{\mathrm{w}}\right)$ higher than 70,000 $\mathrm{kgmol}^{-1}$ were prepared for subsequent membrane fabrication.

Table 3-1 Physi properties of hydroxy copolyimides and polyimides.cal

\begin{tabular}{|c|c|c|c|c|}
\hline Polymer & $\begin{array}{c}\mathrm{Mw} \\
(\mathrm{kg} / \mathrm{mol})\end{array}$ & $\begin{array}{c}\mathrm{M}_{\mathrm{n}} \\
(\mathrm{kg} / \mathrm{mol})\end{array}$ & $\begin{array}{c}\rho \\
\left(\mathrm{g} / \mathrm{cm}^{3}\right)\end{array}$ & $\mathrm{FFV}$ \\
\hline APAF10 & 107,000 & 10,700 & 1.54 & 0.138 \\
\hline APAF8-DAM2 & 93,000 & 10,700 & 1.49 & 0.156 \\
\hline APAF5-DAM5 & 78,000 & 14,000 & 1.42 & 0.172 \\
\hline APAF2-DAM8 & 70,000 & 12,500 & 1.36 & 0.192 \\
\hline$A P A F 8-O D A 2$ & 88,000 & 10,000 & 1.52 & 0.145 \\
\hline$A P A F 5-O D A 5$ & 286,000 & 14,300 & 1.49 & 0.152 \\
\hline$A P A F 2-O D A 8$ & 414,000 & 14,300 & 1.48 & 0.144 \\
\hline$H A B 10$ & 125,000 & 32,000 & 1.49 & 0.118 \\
\hline$H A B 8-D A M 2$ & 96,000 & 38,400 & 1.42 & 0.152 \\
\hline$H A B$ 5-DAM5 & 115,000 & 34,000 & 1.38 & 0.173 \\
\hline$H A B$ 2-DAM8 & 85,000 & 23,000 & 1.34 & 0.190 \\
\hline$H A B$ 8-ODA2 & 144,000 & 42,300 & 1.44 & 0.126 \\
\hline$H A B$ 5-ODA5 & 111,000 & 28,500 & 1.46 & 0.140 \\
\hline$H A B$ 2-ODA8 & 203,000 & 24,500 & 1.48 & 0.159 \\
\hline$P I(6 F D A-D A M)$ & 77,000 & 8,100 & 1.30 & 0.211 \\
\hline$P I(6 F D A-O D A)$ & $160,000 *$ & 25,800 & 1.42 & 0.177 \\
\hline
\end{tabular}




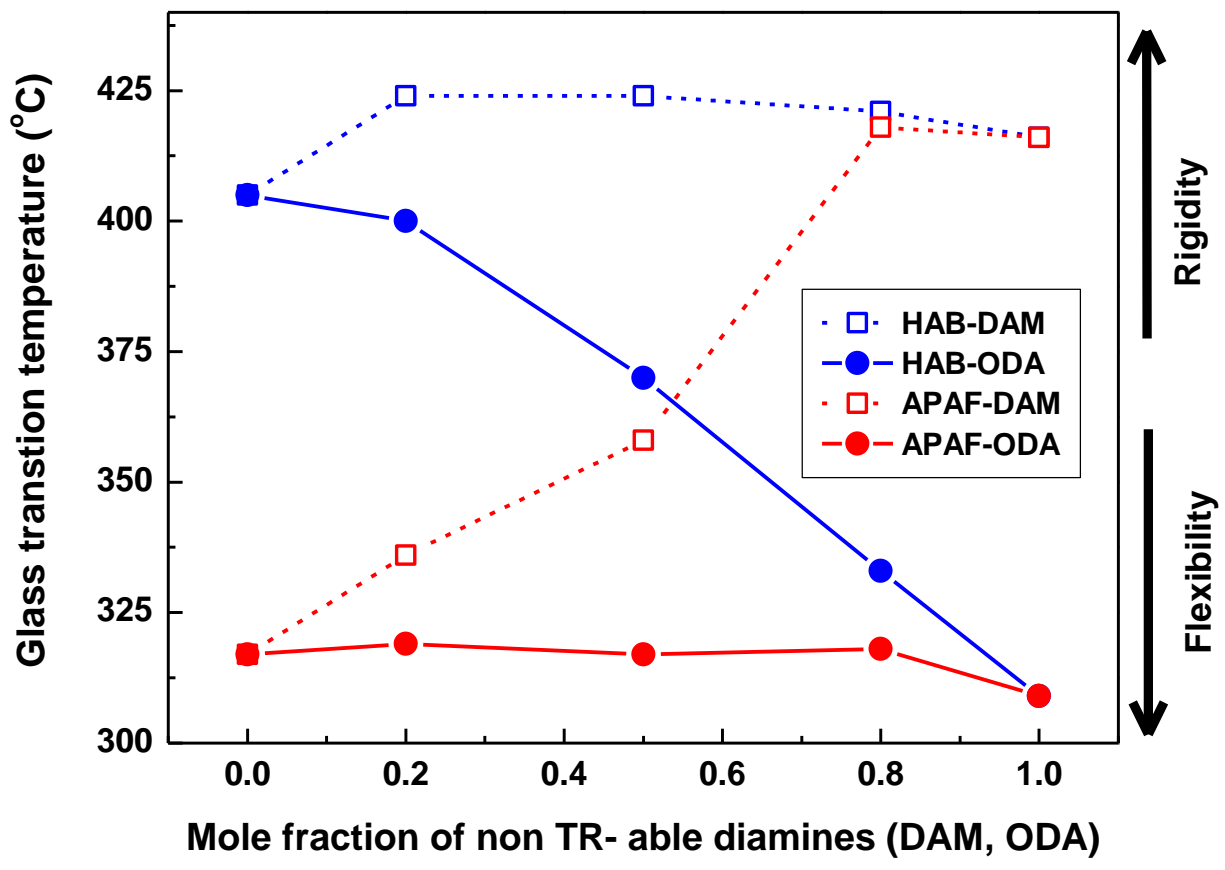

Figure 3-1 Glass transition temperatures $\left(\mathrm{T}_{\mathrm{g}}\right)$ of APAF-DAM, APAF-ODA, HABDAM, and HAB-ODA as a function of mole fraction of non-TRable diamines as measured by dynamic mechanical analysis (DMA).

The effect of the chemical structure of precursor polyimides on their thermal properties (e.g. glass transition temperature and thermal rearrangement temperature) has been studied extensively in the past, and chain flexibility has been identified as a critical factor determining the thermal properties of both hydroxyl polyimides and hydroxyl copolyimides. ${ }^{44}$ In this study, we performed dynamic mechanical analysis (DMA) to determine the glass transition temperature $\left(\mathrm{T}_{\mathrm{g}}\right)$ of the polymer samples, as DMA offers better sensitivity than differential scanning calorimetry (DSC), especially at temperatures higher than $400^{\circ} \mathrm{C}$. Fluor-based 
hydroxyl copolyimides and hydroxyl polyimides prepared here had a $\mathrm{T}_{\mathrm{g}}$ higher than $300^{\circ} \mathrm{C}$ as shown in Figure 3-1 and Table 3-2. Among all hydroxyl copolyimides, APAF-ODA hydroxyl copolyimides showed the lowest $\mathrm{T}_{\mathrm{g}}\left(317^{\circ} \mathrm{C}\right)$, whereas HAB-DAM showed the highest $\left(424^{\circ} \mathrm{C}\right)$. It was also noted that the $\mathrm{T}_{\mathrm{g}}$ of APAF-DAM increased gradually with the addition of non-TRable DAM in the TR-able APAF. However, this behavior was not observed for APAF-ODA, where the $T_{g}$ of APAF-ODA did not change significantly upon the addition of non-TR-able ODA, but the $\mathrm{T}_{\mathrm{g}}$ of the $100 \%$ ODA-containing polyimide decreased slightly. In contrast, when HAB was used as the TR-able component, addition of non-TR-able DAM had a negligible influence on $\mathrm{T}_{\mathrm{g}}$, with only a slight increase from $405^{\circ} \mathrm{C}$ to $424^{\circ} \mathrm{C}$ when $20 \%$ DAM was added. However, replacing DAM with ODA resulted in a steady decrease in $T_{g}$ when increasing the molar ratio of non-TR-able ODA in HAB-containing copolyimides.

This opposite trend for $\mathrm{T}_{\mathrm{g}}$ was observed for different combinations of TR-able and nonTR-able diamines, mainly due to the chemical structure of these components, as increasing the polymer chain rigidity usually leads to a higher $\mathrm{T}_{\mathrm{g}}$. We attributed the generally higher $\mathrm{T}_{\mathrm{g}}$ of HAB-containing copolyimides than APAF-containing copolyimides to the better chain packing efficiency of HAB, which enhanced polymer chain rigidity. In terms of non-TR-able DAM and ODA, the three methyl substitutes in DAM restricted main chain movement; much lower flexibility is therefore expected for DAM than ODA, which contains a rotational ether group. ${ }^{45}$ 
(a)

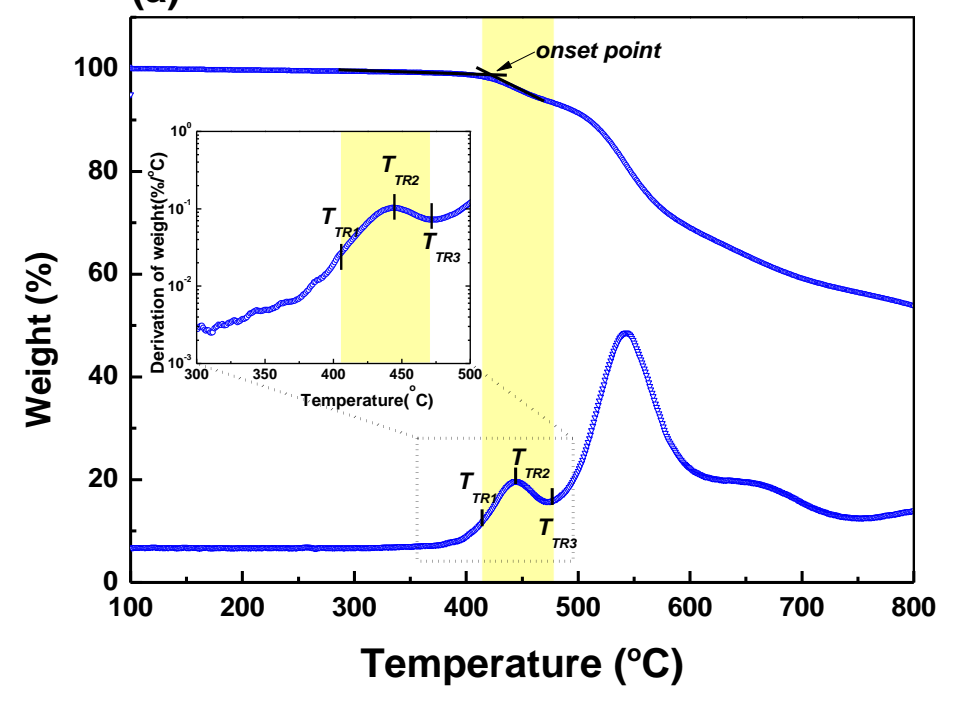

(b)

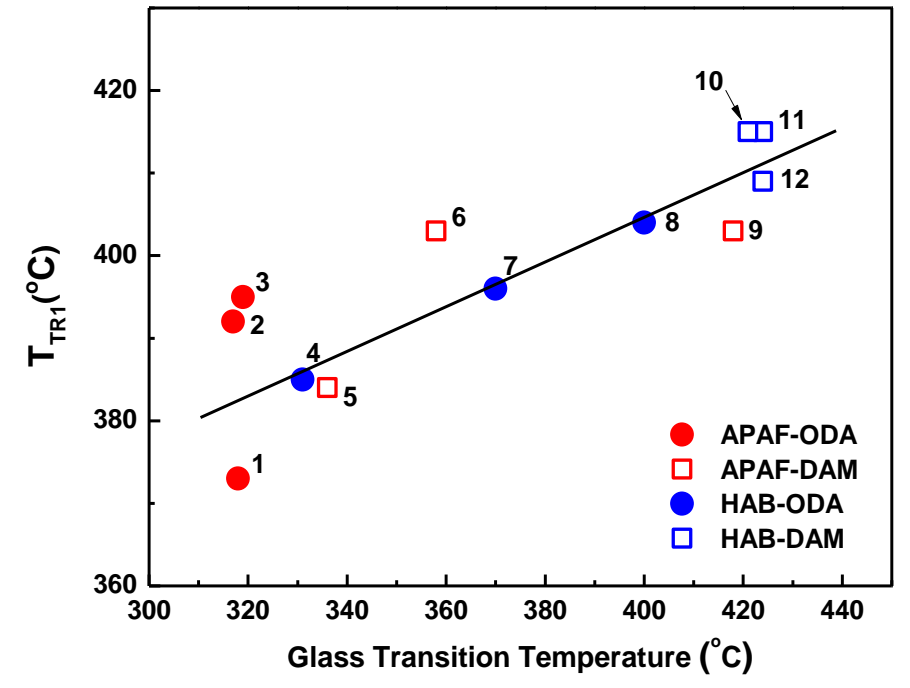

Figure 3-2 (a) Thermal rearranged temperature ( $\left.\mathrm{T}_{\mathrm{TRs}}\right)$ analysis using TGA and weight perc entage variations of HAB5-DAB5 in the range of 100 to $800^{\circ} \mathrm{C} / \mathrm{min}$. (b) The $\mathrm{T}_{\mathrm{TR} 1}$ of di fferent hydroxyl copolyimides as a function of their corresponding $\mathrm{T}_{\mathrm{g}}$. (1) APAF2-ODA 8, (2) APAF5-ODA5, (3) APAF8-ODA2, (4) HAB2-ODA8, (5) APAF8-DAM2, (6) APA F5-DAM5, (7) HAB5-ODA5, (8) HAB8-ODA2, (9) APAF2-DAM8, (10) HAB2-DAM8, (11) HAB5-DAM5, (12) HAB8-DAM2. The trend line is provided to guide the eye. 
The chain mobility of precursor hydroxyl polyimides had a strong influence on thermal rearrangement temperatures. The relationship between $T_{g}$ (indicator of chain mobility) and the initial, maximal, and terminal thermal rearrangement temperatures $\left(\mathrm{T}_{\mathrm{TR} 1}, \mathrm{~T}_{\mathrm{TR} 2}\right.$, and $\mathrm{T}_{\mathrm{TR} 3}$, respectively) was thoroughly investigated in this study, and the results are summarized in Table 3-2. Furthermore, the $\mathrm{T}_{\mathrm{TR} 1}$ of different hydroxyl copolyimides as a function of $\mathrm{T}_{\mathrm{g}}$ are plotted in Figure 3-2(b). It should be noted that unlike in previous studies, $\mathrm{T}_{\mathrm{TR} 1}$ was defined as the onset point of the first slope of weight loss in this study for accurate comparison.

A clear trend of $\mathrm{T}_{\mathrm{TR} 1}$ increasing along with $\mathrm{T}_{\mathrm{g}}$ is evident in Figure $2 \mathrm{~b}$, indicating that the thermal rearrangement reaction of highly rigid hydroxyl copolyimides (indicated by the higher $\mathrm{T}_{\mathrm{g}}$ ) took place at much higher temperature than that of flexible polymers (indicated by the higher $\mathrm{T}_{\mathrm{TR} 1}$ ). Thus, the more rigid hydroxyl copolyimides required higher energy to initiate thermal rearrangement than the less rigid polymers. Unlike the clear increasing trend of $\mathrm{T}_{\mathrm{TR} 1}$ along with $T_{g}, T_{T R 2}$ and $T_{T R 3}$ of each hydroxyl copolyimide were not greatly affected by $T_{g}$, as summarized in Table 3-2. Therefore, the gap between $\mathrm{T}_{\mathrm{TR} 1}$ and $\mathrm{T}_{\mathrm{TR} 3}(\Delta \mathrm{TR})$ became narrower at a higher $\mathrm{T}_{\mathrm{g}}$. For instance, the more rigid HAB-DAM polymers showed a gap as low as $55^{\circ} \mathrm{C}$, which was much narrower than the $\Delta$ TR of flexible APAF-ODA polymers between 88 and $98^{\circ} \mathrm{C}$.

The completeness of thermal conversion from hydroxyl imide to benzoxazole was indicated by the percentage conversion $(\% C)$ and results are presented in Table 3-3; however, potential errors due to weight loss measurement during thermal treatment should be kept in mind.[15, 31, 40] As shown in Table 3-3, 90-100\% conversion was obtained for TR-PBOI membranes from hydroxy copolyimides containing ODA as a non-TR-able diamine. 
Conversion percentages higher than $100 \%$ obtained for the hydroxyl copolyimides with $80 \%$ ODA were mainly due to thermal decomposition because of the low thermal stability of these membranes.

Table 3-2 Glass transition temperature and thermal rearrangement temperature of each hydroxyl copolyimide.

\begin{tabular}{|c|c|c|c|c|c|c|c|c|c|c|c|}
\hline \multirow{2}{*}{ TR-PBOI } & $\mathrm{Tg}_{\mathrm{g}}$ & TTR1 & $\mathrm{T}_{\text {TR2 }}$ & $\mathrm{T}_{\mathrm{TR} 3}$ & $\Delta \mathrm{TR}^{\mathrm{a}}$ & \multirow{2}{*}{ TR-PBOI } & $\mathrm{Tg}_{\mathrm{g}}$ & $\mathrm{T}_{\mathrm{TR} 1}$ & $\mathrm{~T}_{\mathrm{TR} 2}$ & $\mathrm{~T}_{\text {TR3 }}$ & $\Delta \mathrm{TR}$ \\
\hline & $\left({ }^{\circ} \mathrm{C}\right)$ & $\left({ }^{\circ} \mathrm{C}\right)$ & $\left({ }^{\circ} \mathrm{C}\right)$ & $\left({ }^{\circ} \mathrm{C}\right)$ & $\left({ }^{\circ} \mathrm{C}\right)$ & & $\left({ }^{\circ} \mathrm{C}\right)$ & $\left({ }^{\circ} \mathrm{C}\right)$ & $\left({ }^{\circ} \mathrm{C}\right)$ & $\left({ }^{\circ} \mathrm{C}\right)$ & $\left({ }^{\circ} \mathrm{C}\right)$ \\
\hline APAF10 & 317 & 374 & 436 & 490 & 116 & HAB10 & 405 & 393 & 436 & 491 & 98 \\
\hline $\begin{array}{l}\text { APAF8- } \\
\text { DAM2 }\end{array}$ & 336 & 384 & 437 & 490 & 106 & $\begin{array}{l}\text { HAB8- } \\
\text { DAM2 }\end{array}$ & 424 & 409 & 449 & 487 & 78 \\
\hline $\begin{array}{l}\text { APAF5- } \\
\text { DAM5 }\end{array}$ & 358 & 403 & 456 & 490 & 87 & $\begin{array}{l}\text { HAB 5- } \\
\text { DAM5 }\end{array}$ & 424 & 415 & 445 & 475 & 60 \\
\hline $\begin{array}{l}\text { APAF2- } \\
\text { DAM8 }\end{array}$ & 418 & 403 & 458 & 489 & 86 & $\begin{array}{l}\text { HAB 2- } \\
\text { DAM8 }\end{array}$ & 421 & 415 & 445 & 470 & 55 \\
\hline $\begin{array}{l}\text { APAF8- } \\
\text { ODA2 }\end{array}$ & 319 & 395 & 434 & 483 & 88 & $\begin{array}{l}\text { HAB 8- } \\
\text { ODA2 }\end{array}$ & 400 & 404 & 431 & 490 & 86 \\
\hline $\begin{array}{l}\text { APAF5- } \\
\text { ODA5 }\end{array}$ & 317 & 392 & 441 & 490 & 98 & $\begin{array}{l}\text { HAB 5- } \\
\text { ODA5 }\end{array}$ & 370 & 396 & 425 & 473 & 77 \\
\hline $\begin{array}{l}\text { APAF2- } \\
\text { ODA8 }\end{array}$ & 318 & 373 & 434 & 471 & 98 & $\begin{array}{l}\text { HAB 2- } \\
\text { ODA8 }\end{array}$ & 340 & 385 & 425 & 467 & 82 \\
\hline
\end{tabular}

a $\Delta \mathrm{TR}=\mathrm{T}_{\mathrm{TR} 3}-\mathrm{T}_{\mathrm{TR} 1}$ 
Table 3-3 Percentage conversion $(\% \mathrm{C})$ from imide to benzoxazole, and the FFV of each TRPBOI membrane.

\begin{tabular}{|c|c|c|c|c|c|}
\hline \multirow{2}{*}{ TR-PBOI } & $\% C$ & FFV & \multirow{2}{*}{ TR-PBOI } & $\% C$ & FFV \\
\hline & (\%) & $(-)$ & & (\%) & $(-)$ \\
\hline APAF10 & 100 & 0.168 & HAB10 & 69 & 0.162 \\
\hline APAF8-DAM2 & 74 & 0.187 & HAB8-DAM2 & 42 & 0.186 \\
\hline APAF5-DAM5 & 53 & 0.192 & HAB5-DAM5 & 55 & 0.182 \\
\hline APAF2-DAM8 & 44 & 0.198 & HAB2-DAM8 & 34 & 0.198 \\
\hline APAF8-ODA2 & 100 & 0.171 & HAB8-ODA2 & 96 & 0.145 \\
\hline APAF5-ODA5 & 95 & 0.164 & HAB5-ODA5 & 95 & 0.156 \\
\hline APAF2-ODA8 & 109 & $0.164^{\mathrm{a}}$ & HAB2-ODA8 & 110 & $0.162^{\mathrm{a}}$ \\
\hline
\end{tabular}

In contrast, DAM-containing hydroxyl copolyimides with high $\mathrm{T}_{\mathrm{TR} 1}$ according to high $\mathrm{T}_{\mathrm{g}}$ exhibited much lower conversion percentages. These results reflect that chain rigidity of precursor polymer strongly influence on the completeness of thermal conversion and a narrower $\Delta \mathrm{TR}$ significantly limits the operating window for thermal rearrangement. Therefore, a high percentage conversion can be achieved by: (i) fine-tuning the polymer chain rigidity by careful selection of the precursor polymer, and (ii) optimizing the thermal treatment protocol, especially in the case of highly rigid polymers with a narrow $\Delta \mathrm{TR}$ gap. 


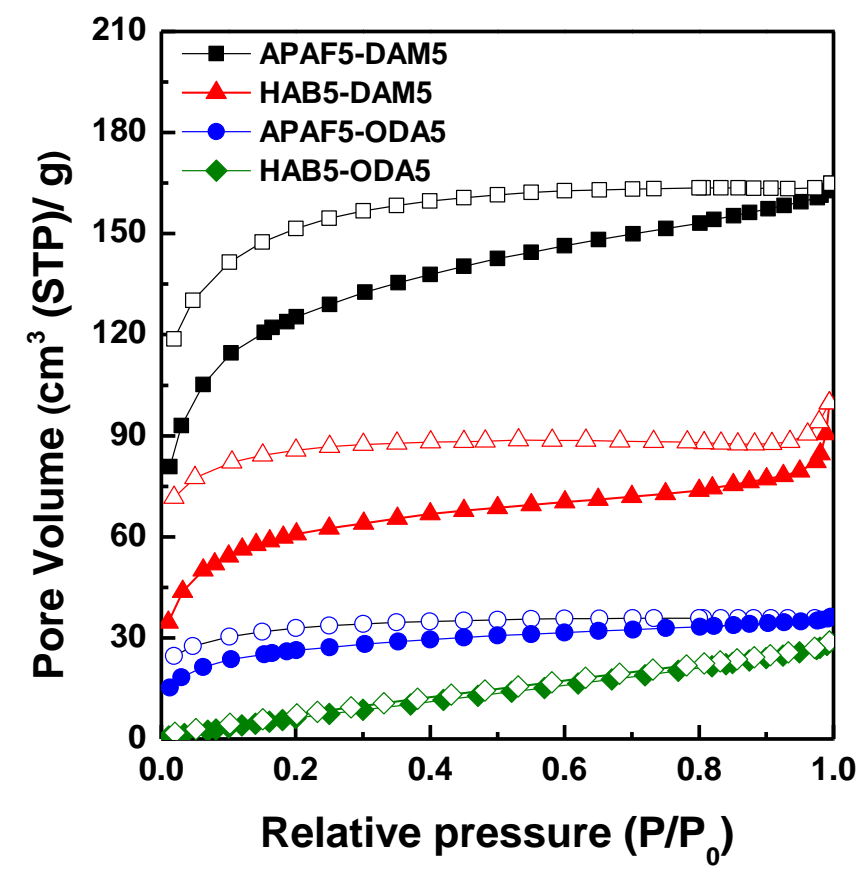

Figure 3-3 Nitrogen adsorption (solid symbols) and desorption (open symbols) isotherms of $\mathrm{f}$ our TR-PBOI membranes (measured at 77K).

We also performed $\mathrm{N}_{2}$ adsorption-desorption tests using four equimolar TR-able and non TR-able diamine-containing TR-PBOIs. The adsorption-desorption isotherms are shown in Figure 3-3, and typical Type I sorption isotherms with apparent hysteresis behavior similar to most micro-porous materials were observed. The sorption of ODA-containing TR-PBOIs was substantially lower than that of their DAM-containing counterparts, indicating the formation of significantly fewer pores and smaller cavities during thermal rearrangement when using ODA as a non-TR-able diamine. We attributed this observation to the highly flexible and rotational polymer chains of ODA restricting the enlargement of micro-cavities, while the bulky methyl groups of rigid DAM disrupted the chain packing efficiency, thus increasing 
micro-cavity size. The BET surface area was also measured based on the $\mathrm{N}_{2}$ adsorptiondesorption test, and the rank order was APAF5-DAM5 (389.4 m³/g) > HAB5-DAM5 (194.7 $\left.\mathrm{m}^{3} / \mathrm{g}\right)>$ APAF5-ODA5 $\left(69.4 \mathrm{~m}^{3} / \mathrm{g}\right)>$ HAB5-ODA5 $\left(40.6 \mathrm{~m}^{3} / \mathrm{g}\right)$, which correlated well with the rank order according to FFV (Table 3-3): APAF5-DAM5 (0.192) > HAB5-DAM5 (0.182) > APAF5-ODA5 (0.164) > HAB5-ODA5 (0.156).

\subsubsection{Mechanical properties of TR-PBOI membranes.}

The mechanical strength of a polymeric membrane plays a critical role in determining the feasibility of industrial implementation of the membrane; not only is the membrane required to withstand high pressure operation, but needs to be sufficiently robust for module fabrication. The tensile strength and elongation at break of the TR-PBOI membranes as a function of mole fraction of non-TR-able diamines are presented in Figure 3-4. Membranes prepared from only TR-able polymers (APAF and HAB) exhibited the lowest tensile strength and elongation at break, while the addition of non-TR-able components (DAM and ODA) enhanced both parameters, except in the case of addition of $80 \%$ ODA to HAB; a slight drop in tensile strength was observed in this case. The slight decrease in tensile strength with the addition of $80 \%$ ODA to HAB was in good agreement with the percentage conversion results (Table 3-3), which we attributed to decomposition during thermal treatment. 

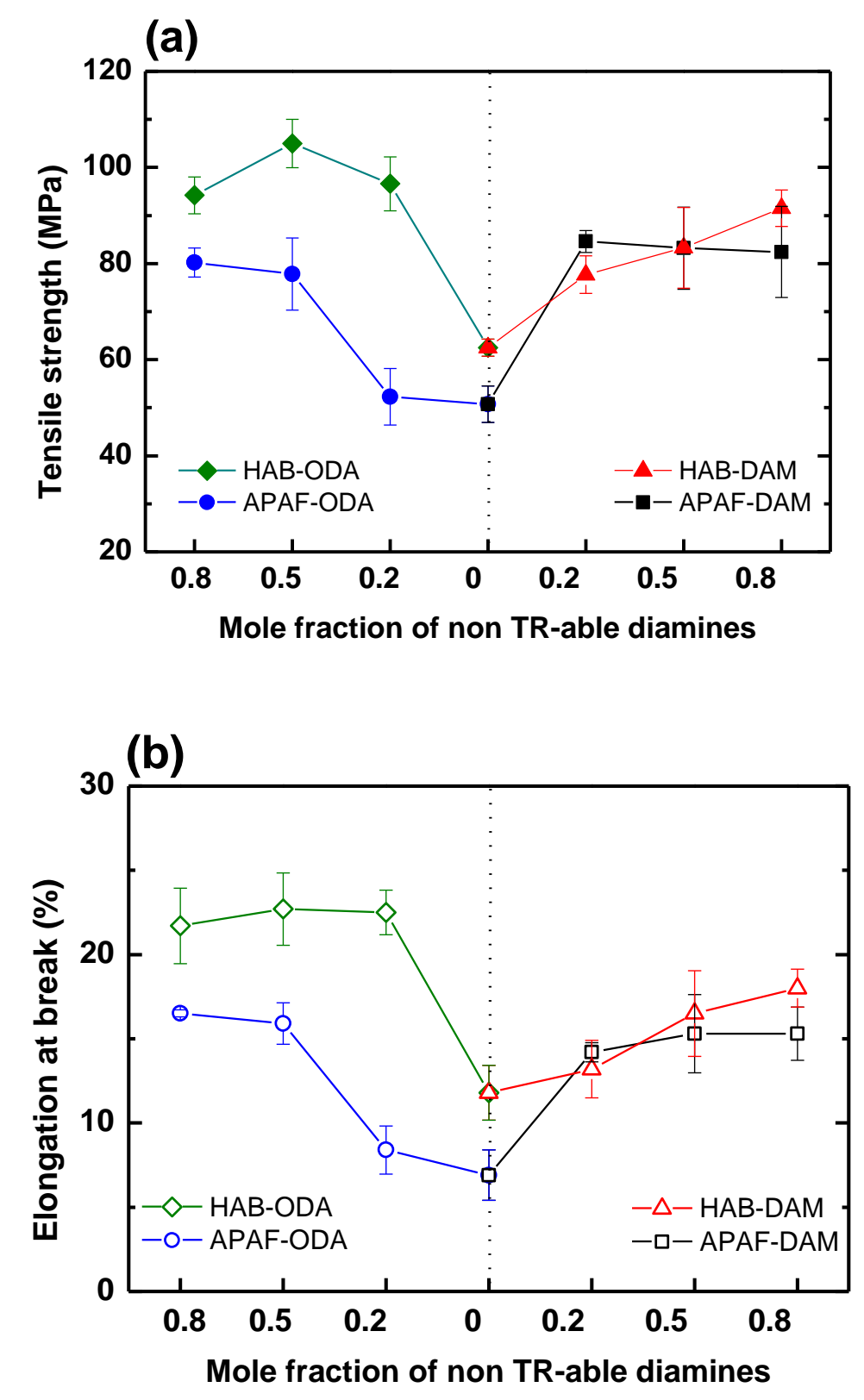

Figure 3-4 (a) Tensile strength, and (b) elongation at break as a function of mole fraction of nonTR-able diamines (ODA and DAM). The origin of the $x$ axis represents membranes containing only TR-able diamines (APAF and HAB). 
Stiff benzoxazole chains formed as a result of thermal rearrangement caused fast deformation, which lowered the mechanical strength of the TR polymer membranes. In contrast, additional non-TR-able ODA and DAM did not undergo the same TR process, and thus the mechanical properties of the corresponding membranes were superior. Further, the improvement in mechanical properties was more pronounced in the case of addition of ODA than DAM, which we attributed to the flexible chemical structure of ODA derived from its rotational ether group.

To better understand the effect of the chemical structure of the diamines on membrane mechanical properties, four TR-PBOIs representatives (APAF5-DAM5, APAF5-ODA5, HAB5-DAM5, and HAB5-ODA5) were selected, and their tensile strength followed the descending order of HAB5-ODA5 (96 MPa) > APAF5-ODA5 (84 MPa) $\approx$ HAB5-DAM5 (83MPa) > APAF5-DAM5 (77 MPa). A high chain packing efficiency and degree of chain orientation improved tensile strength. ${ }^{46}$ Diamines with high packing efficiency and no bulky side groups, such as HAB, had greater tensile strength than APAF. Additionally, as mentioned above, non-TR-able ODA had a higher tensile strength than DAM due to the presence of a rotational ether group in ODA. As a result, the mechanical properties of HAB5-ODA5 were synergistically enhanced. In contrast, the presence of bulky methyl substituents in DAM and the hexafluoropropylidene (6F) group in APAF decreased chain packing efficiency, resulting in lowered tensile strength and elongation at break.

\subsubsection{Gas transport properties of TR-PBOI membranes}


Pure gas permeation studies were performed to determine the relationship between the chemical structure of TR-PBOIs (especially the polymer segmental architecture), ${ }^{47}$ membrane micro-structure (FFV in particular), ${ }^{48}$ and the gas transport properties of the membranes. The tested gases were $\mathrm{He}(2.6 \AA), \mathrm{H}_{2}(2.9 \AA), \mathrm{CO}_{2}(3.3 \AA), \mathrm{O}_{2}(3.5 \AA), \mathrm{N}_{2}(3.6 \AA)$, and $\mathrm{CH}_{4}(3.8 \AA)$. Pure gas permeability and ideal selectivity of the membranes are summarized in Table 3-4. FFV, $\mathrm{CO}_{2}$ diffusivity, and permeability as a function of mole fraction of DAM and ODA are plotted in Figure 3-5(a) and 5(b). In all cases, APAF-containing TR-PBOI membranes exhibited a higher FFV than their HAB-containing counterparts; as a consequence, APAFcontaining membranes had higher diffusivity and permeability than the other membranes evaluated. This behavior was mainly due to the presence of $6 \mathrm{~F}$ groups in APAF, which disrupted the chain packing efficiency and enhanced the formation of larger FFVs. Furthermore, differences in FFV between APAF and HAB became less pronounced when the content of nonTR-able diamines increased, indicating that TR-able diamines were primarily responsible for the formation of large micro-cavities. It should also be noted that similar $\mathrm{CO}_{2}$ permeability was observed when the DAM mole fraction was increased to 80\% for both APAF and HAB (318 Barrer for APAF2-DAM8 and 334 Barrer for HAB2-DAM8). Furthermore, as shown in Table 3-4, the $\mathrm{CO}_{2}$ permeability of these two membranes became higher than their $\mathrm{H}_{2}$ permeability, which is a unique property that has only previously been observed for glassy polymers with excess free volume and stiff main chains or bulky substituents. ${ }^{49}$ Improved $\mathrm{FFV}, \mathrm{CO}_{2}$ diffusivity and permeability, and increased DAM content indicated that gas transport was dominated by gas diffusion through enlarged free volume elements contributed by the bulky methyl groups of DAM (Figure 3-5(a)). In contrast, a substantial decrease in $\mathrm{CO}_{2}$ permeability was observed for ODA-containing TR-PBOI membranes with an increase in ODA ratio. No 
clear correlation was found between $\mathrm{CO}_{2}$ diffusivity and FFV (Figure 3-5(b)). The distribution of free volumes became narrower when flexible components (e.g. ODA) were introduced into the rigid polymer chains, which consequently restricted the passage of gas molecules through the polymer matrix. This phenomenon became more pronounced when the polymer had a number of flexible repeating units [48]. 
Table 3-4 Gas permeability and ideal selectivity of TR-PBOI membranes.

\begin{tabular}{|c|c|c|c|c|c|c|c|c|c|c|}
\hline & \multicolumn{6}{|c|}{ Gas Permeability (Barrer) } & \multicolumn{4}{|c|}{ Ideal Selectivity $(\alpha)$} \\
\hline & $\mathrm{He}$ & $\mathrm{H}_{2}$ & $\mathrm{O}_{2}$ & $\mathrm{~N}_{2}$ & $\mathrm{CO}_{2}$ & $\mathrm{CH}_{4}$ & $\mathrm{O}_{2} / \mathrm{N}_{2}$ & $\mathrm{CO}_{2} / \mathrm{N}_{2}$ & $\mathrm{CO}_{2} / \mathrm{CH}_{4}$ & $\mathrm{H}_{2} / \mathrm{CO}_{2}$ \\
\hline \multicolumn{11}{|l|}{ TR-PBOIs } \\
\hline APAF8-DAM2 & 215.3 & 222.1 & 36.3 & 8.0 & 172.8 & 4.8 & 4.55 & 21.6 & 36.0 & 1.29 \\
\hline APAF5-DAM5 & 243.4 & 286.9 & 53.3 & 12.6 & 269.5 & 8.3 & 4.22 & 21.3 & 32.5 & 1.06 \\
\hline APAF2-DAM8 & 243.4 & 308.6 & 59.8 & 15.2 & 318.1 & 10.2 & 3.93 & 20.9 & 31.3 & 0.97 \\
\hline APAF8-ODA2 & 112.4 & 105.5 & 12.7 & 2.69 & 63.9 & 1.38 & 4.73 & 23.8 & 46.3 & 1.65 \\
\hline APAF5-ODA5 & 93.2 & 86.8 & 10.8 & 2.16 & 57.0 & 1.15 & 4.97 & 26.4 & 49.7 & 1.52 \\
\hline APAF2-ODA8 & 66.8 & 60.8 & 6.88 & 1.35 & 38.5 & 0.73 & 5.08 & 28.4 & 52.9 & 1.58 \\
\hline HAB8-DAM2 & 113.1 & 122.2 & 16.2 & 3.6 & 91.2 & 2.6 & 4.54 & 25.5 & 34.9 & 1.34 \\
\hline HAB5-DAM5 & 176.8 & 203.0 & 32.0 & 7.5 & 185.2 & 5.7 & 4.24 & 23.6 & 32.8 & 1.10 \\
\hline HAB2-DAM8 & 197.9 & 299.1 & 59.8 & 15.3 & 334.4 & 11.8 & 3.91 & 21.9 & 28.3 & 0.89 \\
\hline HAB8-ODA2 & 70.8 & 71.2 & 8.4 & 1.73 & 46.0 & 1.12 & 4.86 & 26.6 & 41.1 & 1.55 \\
\hline HAB5-ODA5 & 59.1 & 55.1 & 5.9 & 1.14 & 33.2 & 0.71 & 5.16 & 29.0 & 46.8 & 1.68 \\
\hline HAB2-ODA8 & 59.6 & 55.8 & 5.5 & 1.0 & 29.3 & 0.57 & 5.45 & 29.2 & 51.8 & 1.90 \\
\hline \multicolumn{11}{|l|}{$T R-P B O s$} \\
\hline APAF10 & 207.5 & 179.9 & 29.4 & 5.2 & 111.8 & 2.4 & 5.60 & 21.4 & 45.8 & 1.61 \\
\hline HAB10 & 84.6 & 86.5 & 10.8 & 2.2 & 59.0 & 1.6 & 4.80 & 26.3 & 36.5 & 1.47 \\
\hline \multicolumn{11}{|l|}{$P I s$} \\
\hline DAM10 & 267.2 & 369.8 & 79.1 & 20.7 & 432.1 & 16.5 & 3.83 & 20.9 & 26.1 & 0.85 \\
\hline ODA10 & 43.8 & 38.3 & 3.55 & 0.63 & 19.3 & 0.35 & 5.65 & 30.7 & 55.0 & 1.98 \\
\hline
\end{tabular}


(a)

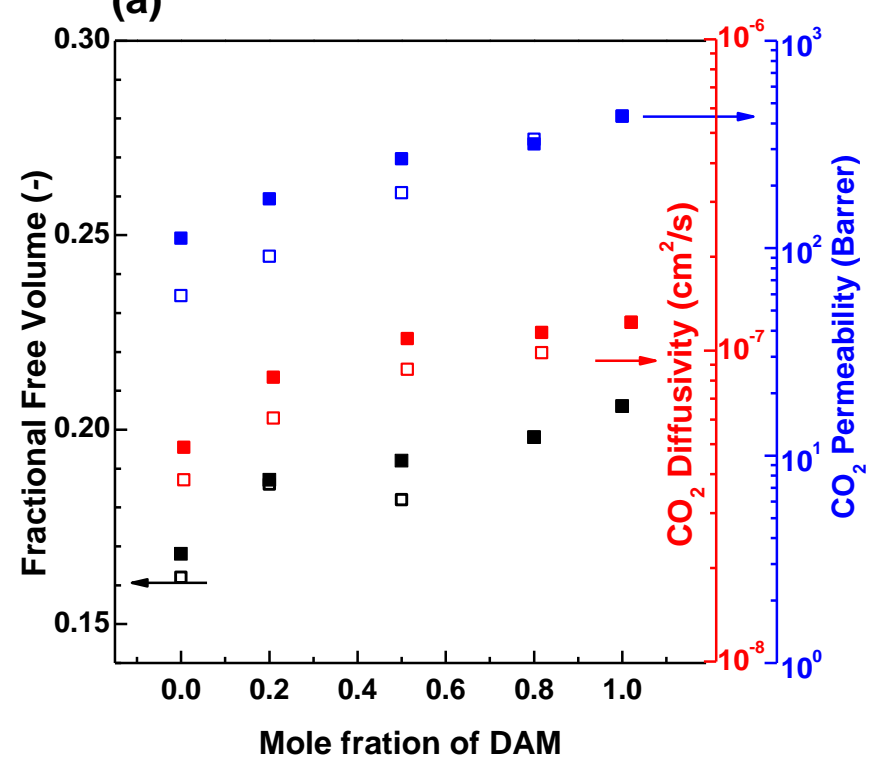

(b)

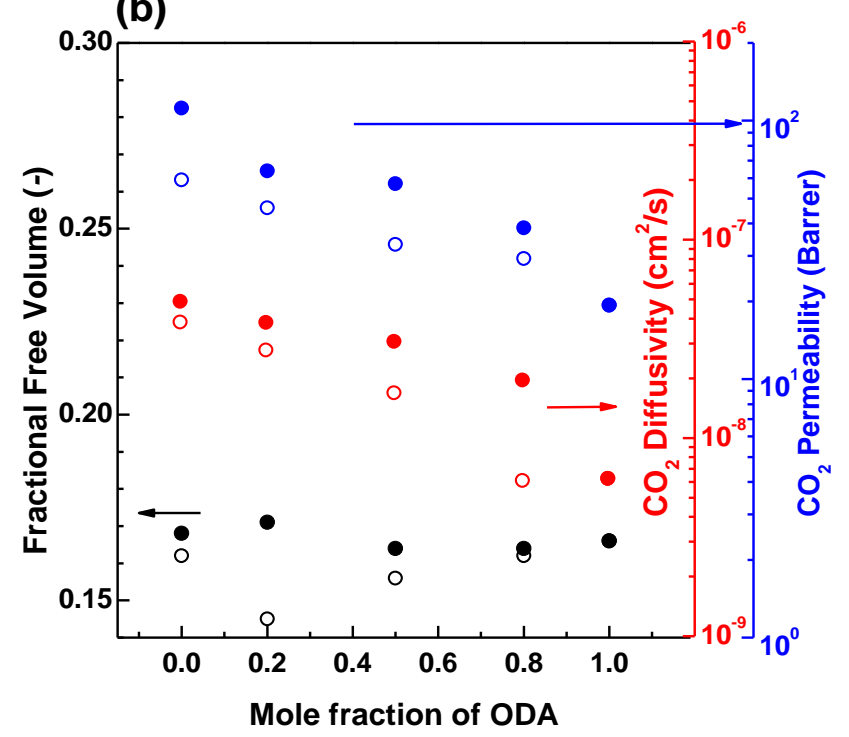

Figure 3-5 Correlation of fractional free volume (black symbols) of TR-PBOI membranes with $\mathrm{CO}_{2}$ permeability (blue symbols) and diffusivity (red symbols) (a) as a function of DAM;

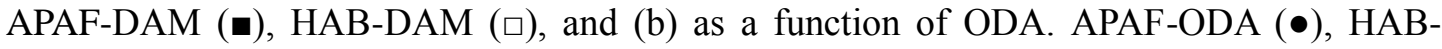
$\operatorname{ODA}(O)$. 
The permeability and ideal selectivity of the membranes to $\mathrm{CO}_{2}, \mathrm{O}_{2}, \mathrm{~N}_{2}$, and $\mathrm{CH}_{4}$ are plotted as a function of mole fraction of non-TR-able diamines in Figure 3-6. Similar to the observation for $\mathrm{CO}_{2}$ (Figure 3-5), the addition of DAM improved permeability to all gas species due to an increase in FFV. Furthermore, APAF-based TR-PBOI membranes were more permeable to gases than those with $\mathrm{HAB}$; however, these difference became less noticeable when the content of non-TR-able diamines increased.

In terms of ideal selectivity, increasing the mole fraction of DAM led to a decrease in ideal selectivity for all gas pairs (Figure 3-6(b)), while in the case of ODA, ideal selectivity increased along with the mole fraction of ODA (Figure 3-6(d)). The presence of bulky methyl side groups in DAM decreased the packing efficiency between polymer chains, which facilitated gas diffusion, but caused the loss of sieving functionality to separate gases. In contrast, the higher electro-negativity of ODA (ether bridging group) increased the strength of chain interactions, thus enhancing the selectivity of the membranes for gas pairs. ${ }^{47,50}$ 


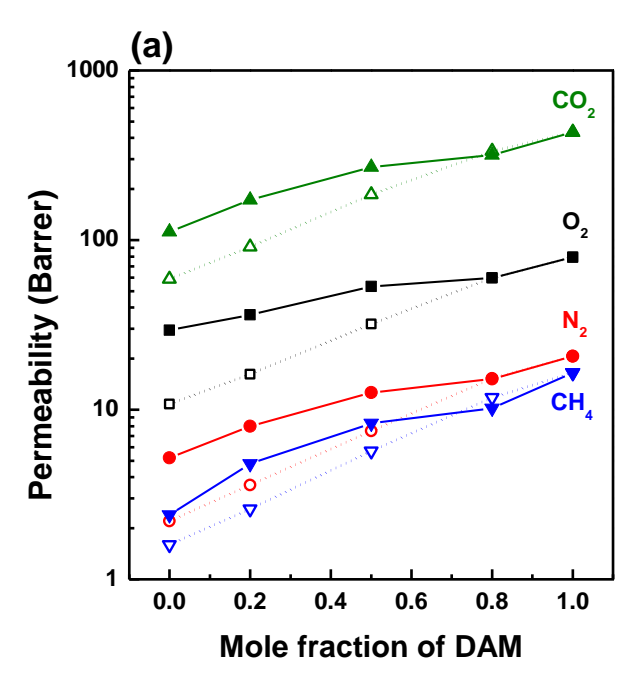

(c)

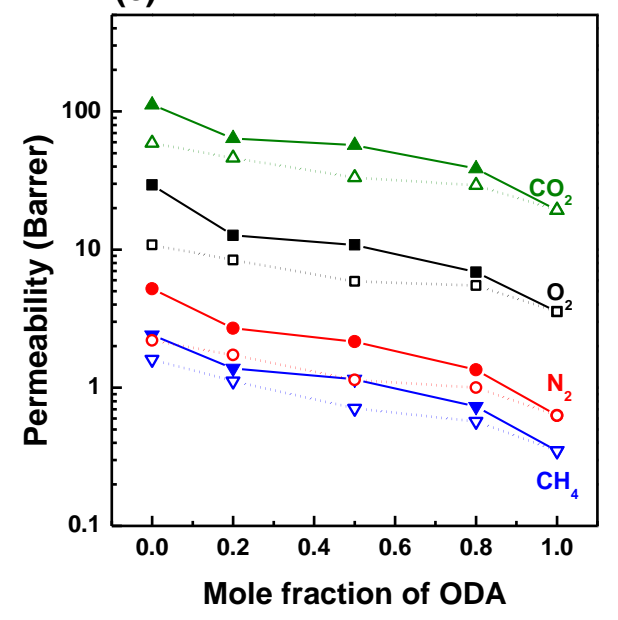

(b)

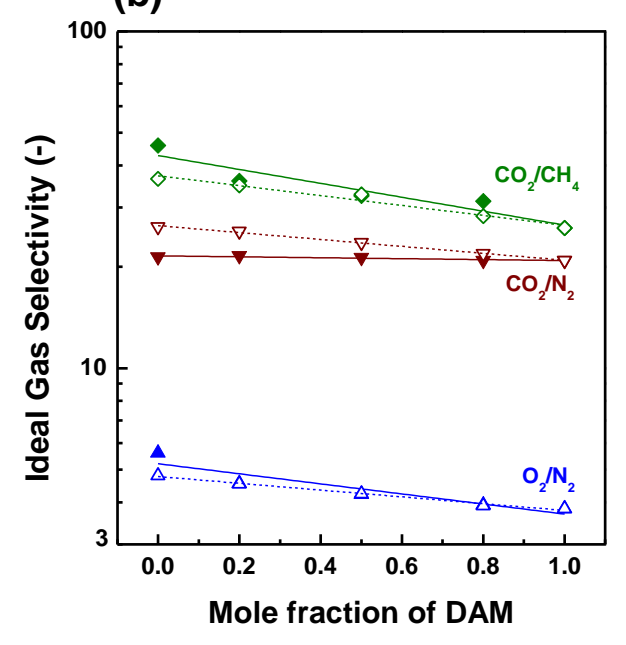

(d)

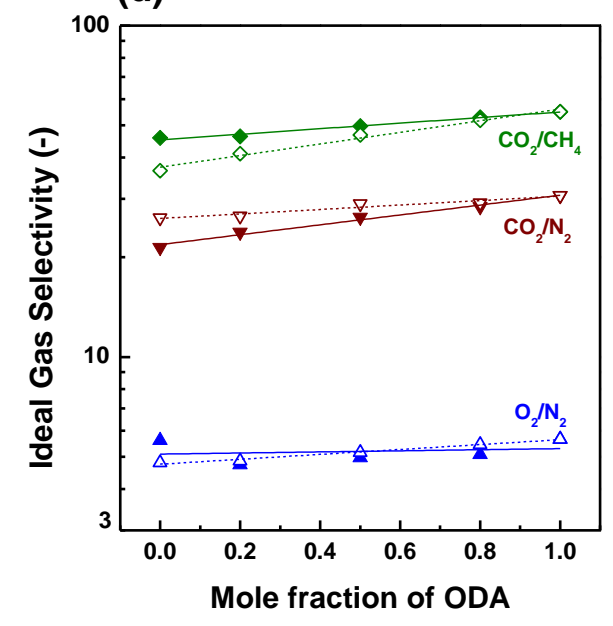

Figure 3-6 (a) Gas permeability and (b) ideal selectivity of TR-PBOI membranes containing APAF-DAM (closed symbols) and HAB-DAM (open symbols), and (c) gas permeability and (d) ideal selectivity of TR-PBOI membranes containing APAF-ODA (closed symbols) and HAB-ODA (open symbols).

Trade-off relationships between the permeability and selectivity of all TR-PBOI membranes are shown in Figure 3-7, along with those for a few typical commercially available 
polymeric membranes for comparison (e.g. Matrimid, PSF, CA, and TB-bisA-PC). ${ }^{51}$ As shown in Figure 3-7(a), all the in-house synthesized TR-PBOI membranes displayed better $\mathrm{CO}_{2} / \mathrm{CH}_{4}$ separation performance than the commercial polymers. Furthermore, most of the TR-PBOI membranes exceeded the 1991 Robeson upper bound, while only slightly lower than the 2008 upper bound, indicating their potential application in natural gas sweetening. In the case of $\mathrm{CO}_{2} / \mathrm{N}_{2}$ separation, as shown in Figure 3-7(b), the TR-PBOI membranes had moderate $\mathrm{CO}_{2} / \mathrm{N}_{2}$ selectivities compared to the commercial polymers; however, the $\mathrm{CO}_{2}$ permeabilities of the TRPBOI membranes were higher than those of commercial polymers. It was noted that the improvement in $\mathrm{CO}_{2} / \mathrm{CH}_{4}$ separation performance of TR-PBOI membranes compared to other commonly used polymeric membranes was greater than the improvement in $\mathrm{CO}_{2} / \mathrm{N}_{2}$ separation performance. It was known that the exceptional separation performance of TR polymers was mainly derived from its fine-tuned cavity size and micro-porosity. As such, the mass transfer within the TR polymer matrix was largely dominated by its high diffusivity. Therefore the permeability improvement for the gas molecules with smaller kinetic diameters such as $\mathrm{N}_{2}$ (3.64 $\AA$ ) was much more pronounced than those with larger kinetic diameters such as $\mathrm{CH}_{4}(3.8$ $\AA$ ), when comparing TR-PBOI membranes with other conventional polymeric membranes. Consequently the improvement in $\mathrm{CO}_{2} / \mathrm{CH}_{4}$ ideal selectivity was much greater than that of the $\mathrm{CO}_{2} / \mathrm{N}_{2}$ ideal selectivity for the same comparison, as evidenced in Figure 3-7, where the $\mathrm{CO}_{2} / \mathrm{CH}_{4}$ data points of the TR-PBOI membranes were much closer to the 2008 Robeson upper bound than the $\mathrm{CO}_{2} / \mathrm{N}_{2}$ data points of the TR-PBOI membranes.

TR-PBOIs prepared in this work underwent a thermal treatment process above $\mathrm{T}_{\mathrm{g}}$. As a result, a rigid main polymer chain was achieved, which was sufficient to resist the plasticization 
and physical aging. The major application for TR-PBOI membranes was carbon capture from post-combustion flue gases, where the pressure was only slightly above atmosphere, thus the plasticization phenomenon was unlikely to take place in this case. In addition, the $\mathrm{CO}_{2}$ permeability of polymer materials is of the utmost importance to determine the $\mathrm{CO}_{2}$ capture cost, considering the huge volume of flue gas to be processed [3].

As such the TR-PBOI membranes fabricated in this study, which have exceptional CO2 permeability and feasibility to industrial implementations, are choice candidates for postcombustion $\mathrm{CO}_{2}$ capture.

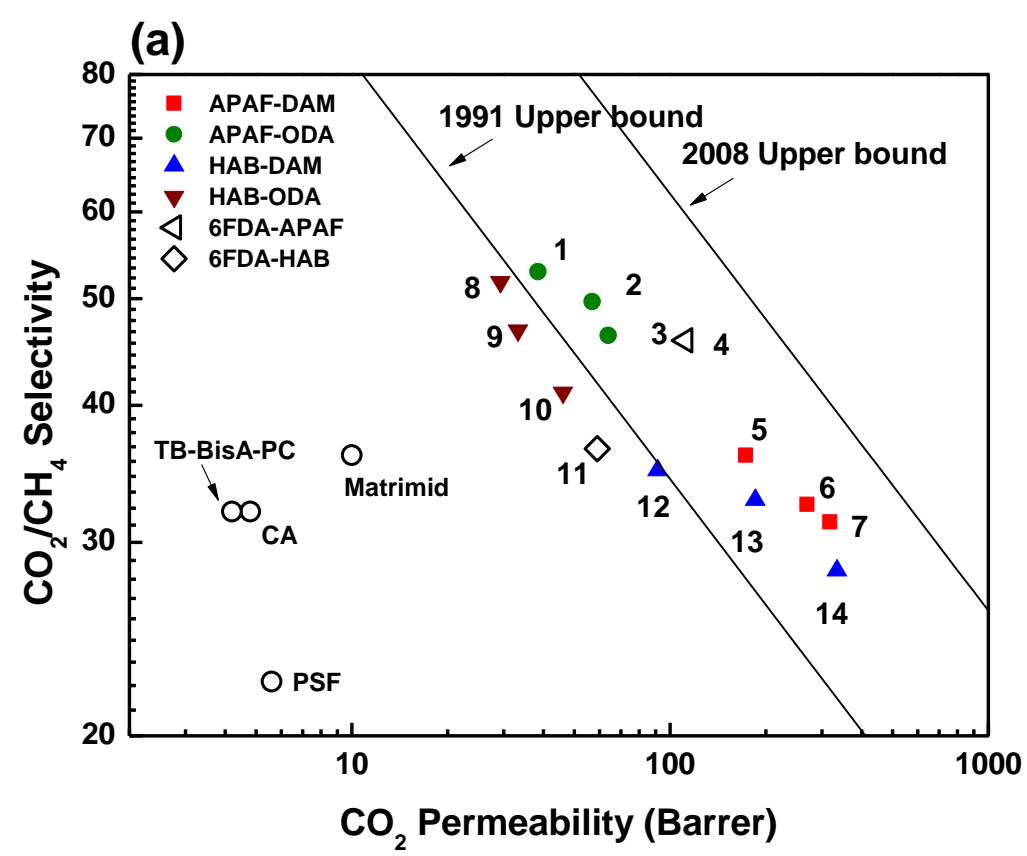




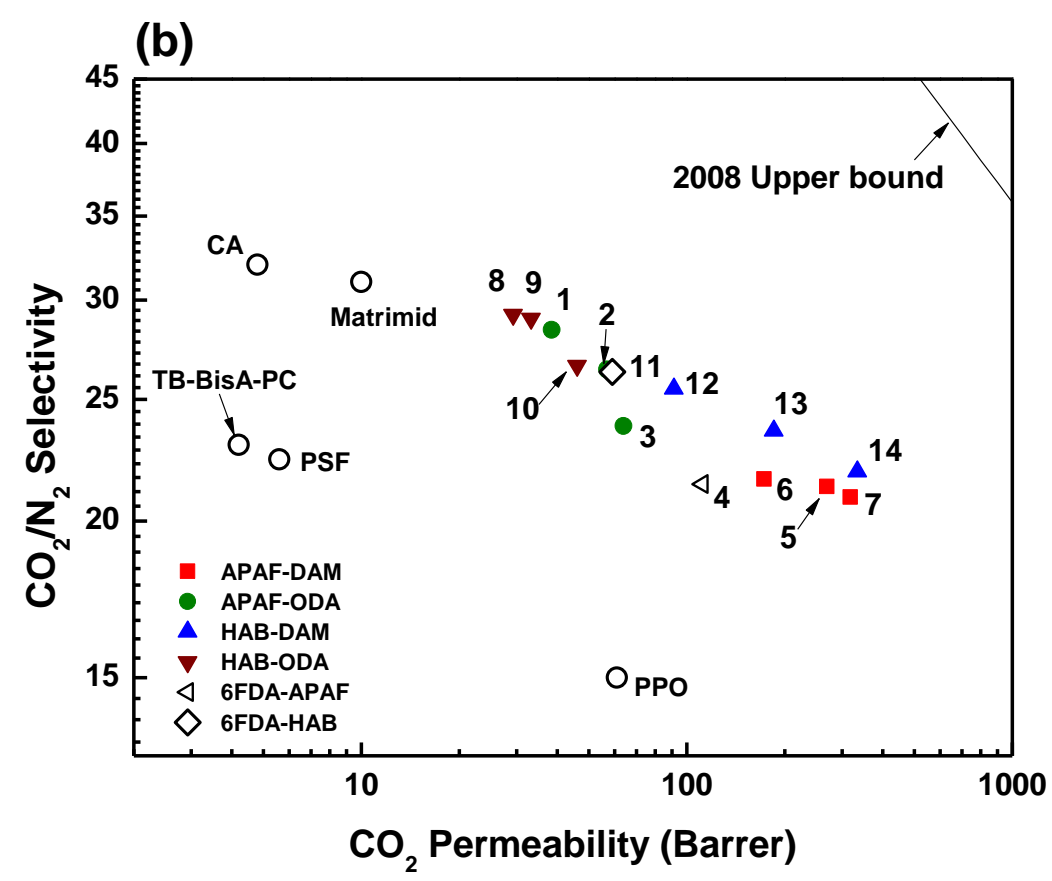

Figure 3-7 Robeson plot of (a) $\mathrm{CO}_{2} / \mathrm{CH}_{4}$ and (b) $\mathrm{CO}_{2} / \mathrm{N}_{2}$ for different TRPBOI membranes. 1991 and 2008 Robeson upper bounds along with benchmark polymers were included for comparison.[33, 34, 51] (1) APAF2-ODA8, (2) APAF5-ODA5, (3) APAF8ODA2, (4) APAF10, (5) APAF8-DAM2, (6) APAF5-DAM5, (7) APAF2-DAM8, (8) HAB2ODA8, (9) HAB5-ODA5, (10) HAB8-ODA2, (11) HAB10, (12) HAB8-DAM2, (13) HAB5DAM5, (14) HAB2-DAM8.

\subsection{Conclusions}

In this work, TR-PBOI membranes with structurally different TR-able and non-TR-able diamines were synthesized to study the relationship between the chemico-physical characteristics of TR-PBOI membranes and their mechanical and gas transport properties.

The study revealed a strong relationship between chain rigidity and thermal conversion behavior (percentage conversion). This could guide optimization of thermal treatment 
protocols. The use of structurally different diamines had a great influence on the mechanical properties of the TR-PBOI membranes. In terms of TR-able diamines, HAB-containing TRPBOI membranes exhibited higher mechanical strength than those with APAF (containing bulky 6F side groups) due to the better chain packing efficiency of HAB. The addition of nonTR-able diamines such as DAM and ODA greatly enhanced the mechanical properties of TRPBOI membranes, especially in the case of ODA, where the presence of a rotational ether group substantially improved chain packing efficiency. As a result, TR-PBOI membranes showed a significant improvement in mechanical strength relative to their TR-PBO counterparts, especially in the HAB-ODA series (up to 70\% improvement in tensile strength and elongation at break).

In terms of gas separation performance, TR-able APAF offered a higher FFV, and thus higher gas permeability than HAB due to the presence of bulky 6F groups in APAF. The additional non-TR-able diamines functioned mainly as chain packing disruptors, especially in the case of DAM with bulky methyl groups, whereas for ODA, the rotational ether group increased the flexibility of the polymer chains, thus lowering FFV and gas permeability. Appropriate selection of TR-able and non-TR-able diamines resulted in excellent gas separation properties $\left(\mathrm{CO}_{2}\right.$ permeability over 300 Barrer and $\mathrm{CO}_{2} / \mathrm{N}_{2}$ ideal selectivity above 20); both of these values are higher than the values reported for the corresponding TR-PBO membranes.

\section{References}

[1] Bernardo, P.; Drioli, E.; Golemme, G. Ind. Eng. Chem. Res. 2009, 48, 4638-4663. 
[2] Kim, S.; Lee, Y. M. Prog. Polym. Sci. 2014 [Online], DOI: 10.1016/j.progpolymsci. 2014.10.005.

[3] Merkel, T. C.; Lin, H. Q.; Wei, X. T.; Baker, R. J. Membr. Sci. 2010, 359 (1-2), 126139.

[4] Masuda, T.; Isobe, E.; Higashimura, T.; Takada, K. J. Am. Chem. Soc. 1983, 105 (25), 7473-7474.

[5] Pinnau, I.; Toy, L. G. J. Membr. Sci. 1996, 109 (1), 125-133.

[6] Park, H. B.; Jung, C. H.; Lee, Y. M.; Hill, A. J.; Pas, S. J.; Mudie, S. T.; Van Wagner, E.; Freeman, B. D.; Cookson, D. J. Science 2007, 318 (5848), 254-8.

[7] Calle, M.; Doherty, C. M.; Hill, A. J.; Lee, Y. M. Macromolecules 2013, 46 (20), 8179-8189.

[8] Park, C. H.; Tocci, E.; Kim, S.; Kumar, A.; Lee, Y. M.; Drioli, E. J. Phys. Chem. B 2014, 118 (10), 2746-2757.

[9] Han, S. H.; Misdan, N.; Kim, S.; Doherty, C. M.; Hill, A. J.; Lee, Y. M. Macromolecules 2010, 43 (18), 7657-7667.

[10] Park, H. B.; Han, S. H.; Jung, C. H.; Lee, Y. M.; Hill, A. J. J. Membr. Sci. 2010, 359 (1-2), 11-24.

[11] Comesaña-Gándara, B.; Calle, M.; Jo, H. J.; Hernández, A.; de la Campa, J. G.; de Abajo, J.; Lozano, A. E.; Lee, Y. M. J. Membr. Sci.. 2014, 450, 369-379.

[12] Sanders, D. F.; Guo, R.; Smith, Z. P.; Stevens, K. A.; Liu, Q.; McGrath, J. E.; Paul, D. R.; Freeman, B. D. J. Membr. Sci. 2014, 463, 73-81.

[13] Sanders, D. F.; Guo, R.; Smith, Z. P.; Liu, Q.; Stevens, K. A.; McGrath, J. E.; Paul, D. R.; Freeman, B. D. Polymer 2014, 55 (7), 1636-1647. 
[14] Guo, R.; Sanders, D. F.; Smith, Z. P.; Freeman, B. D.; Paul, D. R.; McGrath, J. E. J. Mat. Chem. A 2013, 1 (2), 262.

[15] Sanders, D. F.; Smith, Z. P.; Ribeiro, C. P.; Guo, R.; McGrath, J. E.; Paul, D. R.; Freeman, B. D. J. Membr. Sci. 2012, 409-410, 232-241.

[16] Kim, S. J.; Jo, H. J.; Lee, Y. M. J. Membr. Sci. 2013, 441, 1-8.

[17] Budd, P. M.; Elabas, E. S.; Ghanem, B. S.; Makhseed, S.; McKeown, N. B.; Msayib, K. J.; Tattershall, C. E.; Wang, D. Adv. Mater. 2004, 16 (5), 456-461.

[18] Mason, C. R.; Maynard-Atem, L.; Al-Harbi, N. M.; Budd, P. M.; Bernardo, P.; Bazzarelli, F.; Clarizia, G.; Jansen, J. C. Macromolecules 2011, 44 (16), 6471-6479.

[19] Budd, P. M.; McKeown, N. B. Polym. Chem. 2010, 1 (1), 63-68.

[20] Budd, P. M.; Msayib, K. J.; Tattershall, C. E.; Ghanem, B. S.; Reynolds, K. J.; McKeown, N. B.; Fritsch, D. J. Membr. Sci. 2005, 251 (1-2), 263-269.

[21] Madkour, T. M.; Mark, J. E. J. Membr. Sci. 2013, 431, 37-46.

[22] Budd, P. M.; McKeown, N. B.; Ghanem, B. S.; Msayib, K. J.; Fritsch, D.; Starannikova, L.; Belov, N.; Sanfirova, O.; Yampolskii, Y.; Shantarovich, V. Jour. Memb. Sci. 2008, 325 (2), 851-860.

[23] Carta, M.; Malpass-Evans, R.; Croad, M.; Rogan, Y.; Jansen, J. C.; Bernardo, P.; Bazzarelli, F.; McKeown, N. B. Science 2013, 339 (6117), 303-307.

[24] Carta, M.; Croad, M.; Malpass-Evans, R.; Jansen, J. C.; Bernardo, P.; Clarizia, G.; Friess, K.; Lanc, M.; McKeown, N. B. Adv. Mater. 2014, 26 (21), 3526-3531.

[25] Carta, M.; Malpass-Evans, R.; Croad, M.; Rogan, Y.; Lee, M.; Rose, I.; McKeown, N. B. Polym Chem. 2014, 5 (18), 5267-5272.

[26] Wang, Z. G.; Wang, D.; Zhang, F.; Jin, J. $\quad$ Macro. Lett. 2014, 3 (7), 597-601. 
[27] Zhuang, Y. B.; Seong, J. G.; Do, Y. S.; Jo, H. J.; Cui, Z.; Lee, J.; Lee, Y. M.; Guiver, M. D. Macromolecules 2014, 47 (10), 3254-3262.

[28] Seong, J. G.; Zhuang, Y.; Kim, S.; Do, Y. S.; Lee, W. H.; Guiver, M. D.; Lee, Y. M. J. Membr. Sci.. 2015 [Online], doi:10.1016/j.memsci.2015.01.022.

[29] Shamsipur, H.; Dawood, B. A.; Budd, P. M.; Bernardo, P.; Clarizia, G.; Jansen, J. C. Macromolecules 2014, 47 (16), 5595-5606.

[30] Li, S.; Jo, H. J.; Han, S. H.; Park, C. H.; Kim, S.; Budd, P. M.; Lee, Y. M. J. Membr. Sci. 2013, 434, 137-147.

[31] Wang, Z. G.; Liu, X.; Wang, D.; Jin, J. Polym. Chem. 2014, 5 (8), 2793-2800.

[32] Guiver, M. D.; Lee, Y. M. Science 2013, 339 (6117), 284-5.

[33] Robeson, L. M. J. Membr. Sci. 1991, 62, 165-185.

[34] Robeson, L. M. J. Membr. Sci. 2008, 320 (1-2), 390-400.

[35] Calle, M.; Lee, Y. M. Macromolecules 2011, 44 (5), 1156-1165.

[36] Kim, S.; Han, S. H.; Lee, Y. M. J. Membr. Sci. 2012, 403-404, 169-178.

[37] Chen, B.-K.; Tsai, Y.-J.; Tsay, S.-Y. Polym. Inter. 2006, 55 (1), 93-100.

[38] Scholes, C. A.; Ribeiro, C. P.; Kentish, S. E.; Freeman, B. D. Sep. Purif. Technol. 2014, 124, 134-140.

[39] Scholes, C. A.; Ribeiro, C. P.; Kentish, S. E.; Freeman, B. D. J. Membr. Sci. 2014, 450, 72-80.

[40] Jung, C. H.; Lee, J. E.; Han, S. H.; Park, H. B.; Lee, Y. M. J. Membr. Sci. 2010, 350 (1-2), 301-309.

[41] Soo, C. Y.; Jo, H. J.; Lee, Y. M.; Quay, J. R.; Murphy, M. K. J. Membr. Sci. 2013, 444, 365-377. 
[42] Bondi, A. J. Phys. Chem. 1964, 68, 441-451.

[43] Park, J. Y.; Paul, D. R. J. Membr. Sci. 1997, 125, 23-39.

[44] Calle, M.; Chan, Y.; Jo, H. J.; Lee, Y. M. Polymer 2012, 53 (13), 2783-2791.

[45] Acar, H. Y.; Ostrowski, C.; Mathias, L. J., Investigation of structure-property relationships in aromatic polyimides and polyamides. In Polyimides and Others High Temperature Polymers, Mittal, K. L., Ed. VSO BV: The Netherlands, 2001; Vol. 1, pp 3-18.

[46] Pukanszky, B. Composites 1990, 21 (3), 255-262.

[47] Xiao, Y. C.; Low, B. T.; Hosseini, S. S.; Chung, T. S.; Paul, D. R. Prog. Polym. Sci. 2009, 34 (6), 561-580.

[48] Maier, G. Angew. Chem. Int. Edit. 1998, 37 (21), 2961-2974.

[49] Lau, C. H.; Li, P.; Li, F. Y.; Chung, T. S.; Paul, D. R. Prog. Polym. Sci. 2013, 38 (5), 740-766.

[50] Ando, S.; Matsuura, T.; Sasaki, S. poly. Jour. 1997, 29 (1), 69-76.

[51] Sanders, D. E.; Smith, Z. P.; Guo, R. L.; Robeson, L. M.; McGrath, J. E.; Paul, D. R.; Freeman, B. D. Polymer 2013, 54 (18), 4729-4761. 


\section{Chapter 4}

\section{Mechanically robust thermally rearranged (TR) polymer membranes with spirobisindane for gas separation}

This paper has been published as: S. Li, H.J. Jo, S.H. Han, C.H. Park, S. Kim, P.M. Budd, Y.M. Lee, Mechanically robust thermally rearranged (TR) polymer membranes with spirobisindane for gas separation, Journal of Membrane Science, 434 (2013) 13 7-147. 


\subsection{Introduction}

Since the first report of the membrane-based separation concept by Graham in 1866[1], membranes have been developed and utilized on an industrial scale for air separation, hydrogen recovery, and hydrocarbon/light gas separation. The realization that $\mathrm{CO}_{2}$ emitted by fossil fuel combustion is a major greenhouse gas, and that global warming is an urgent issue worldwide, has prompted research into $\mathrm{CO}_{2}$ removal not only from the atmosphere and natural gas but also from flue gas, for carbon capture and storage (CCS).

Membrane technology is attractive in terms of large industrial scale separation, possibility to improve efficiency, and cost effectiveness[2] . Note that newly built power plants need to achieve $90 \% \mathrm{CO}_{2}$ capture with no more than $35 \%$ increase in the cost of electricity[3]]. Three strategies, combined with different separation processes, can be applied for $\mathrm{CO}_{2}$ capture in power plants: (1) oxy-fuel combustion, using air separation to produce oxygen enriched gas for the combustion process, resulting in an exhaust rich in $\mathrm{CO}_{2}$; (2) $\mathrm{CO}_{2}$ separation from syngas prepared by coal gasification and the water gas shift (WGS) process $\left(\mathrm{H}_{2} / \mathrm{CO}_{2}\right.$ separation); (3) post-combustion capture, $\mathrm{CO}_{2}$ separation from flue gas composed of mainly $\mathrm{CO}_{2}$ and $\mathrm{N}_{2}$ at relatively low temperature and pressure. In post-combustion capture, high gas permeability and flux in membrane materials are more important than selectivity, provided the selectivity of $\mathrm{CO}_{2} / \mathrm{N}_{2}$ is above 20. In addition, if $\mathrm{CO}_{2}$ flux is more than 3,000 gas permeation unit (GPU), $\mathrm{CO}_{2}$ capture costs can be reduced below $\$ 20$ per ton of $\mathrm{CO}_{2}$ capture without a feed compressor[ㄴ]

Membranes are fabricated as thin-film composites, spiral-wounds, or hollow fibers in a 
module. Generally, hollow fiber membranes are industrially applicable due to their high packing density, i.e., high membrane area per unit volume. To prepare hollow fiber membranes, the most important requirement is the continuous fabrication of a thin and defect-free top-layer (typically $<0.2 \mu \mathrm{m}$ ), so as to reduce operation cost by increasing gas flux. Manufacturing membranes with good mechanical properties, ensuring no mechanical failure or membrane defect, is a major obstacle to commercialization of highly permeable materials. Furthermore, polymeric membranes still need to overcome some challenges such as plasticization resistance and physical aging tolerance for long-term, efficient process operation []].

Several strategies have been developed to design high performance polymeric materials for gas separation, surpassing current limitations of physical and transport properties. Based on the 'solution-diffusion' mechanism which governs transport of small gases through polymers, one way is to enhance the diffusive pathways by controlling pore size and free volume[] $]$ and another is to increase chemical interaction between the targeted gas molecule and polymers[]].

In order to increase free volume between polymer chains, many researchers have introduced bulky side groups or created an intrinsically porous rigid backbone in the main chain structure[8-10]. The introduction of a non-coplanar structure into polymer chains also prevents chain packing and alignment. A spiro-centre is a non-coplanar structure composed of two adjacent rings orthogonal to one another, with a tetrahedral bonding atom[11]. The twisted $90^{\circ}$ angle of this structure restricts polymer chain packing and inter-chain interactions. Over the past few years, several spiro-center-containing polyimides with excellent solubility and 
thermal stability have been developed[12] by synthesizing diamines and dianhydrides[13-15] with a spiro-center[16-18].

Budd and McKeown synthesized organic-soluble polymers of intrinsic microporosity (PIMs) composed of a ladder-type pattern, constructed using a dibenzodioxane-forming reaction, with a $90^{\circ}$ kinked spiro-center in a repeating unit[19]. These ladder-like polymers have an unusually high internal surface area and therefore show superior gas permeability, because the ladder-like structures do not stack regularly[모 20]. The first reported soluble PIM (PIM-1) had a Brunauer-Emmett-Teller (BET) surface area of $850 \mathrm{~m}^{2} / \mathrm{g}$; various subsequent variations of PIMs have resulted in BET surface areas up to $1760 \mathrm{~m}^{2} / \mathrm{g}[\underline{21}]$. Recently, two types of hydroxyl-functionalized polyimides with intrinsic microporosity were synthesized and shown to be good candidates for gas separation applications [22] .

Thermally rearranged (TR) polymers also have extraordinary microporous properties due to the presence of microcavities formed during thermal rearrangement of the precursor polymer. In the solid state, the well-packed polyimide precursors are converted into heterogeneous aromatic rigid-rod polymers, providing free space in the polymer matrix. The microcavities can be tuned for transport, storage, and separation of large gas molecules[ $[\underline{6}, \underline{23-26}]$ as well as smaller gas molecules[27], or even ions such as protons and acid molecules[ㅁ].The most permeable TR polymer obtained an incredible increment of fractional free volume of up to $96 \%$ during the thermal rearrangement process from hydroxyl polyimide, HPI[28].

Although microporous polymer materials possess superior surface area, poor mechanical properties and low elongation are critical issues in polymer processing. TR polymers exhibit 
high tensile strength; however, they show low elongation at break $(<5 \%)$ and are brittle after thermal treatment at high temperatures. Recently thermally cross-linked polyimides[29], thermally cross-linked PIM-1[을 and co-polyimides grafted with thermally labile betacyclodextrin (CD) side groups[1ㅡ have been suggested, but there still remains a concern about the brittleness after thermal treatment. Therefore, it is important to develop polymer materials for gas separation and carbon capture with high free volume coupled with high mechanical strength and elongation at break, which is regarded as a challenging task as these two properties are contradictory to each other.

Here, we report on new and mechanically robust thermally rearranged polybenzoxazoles with a spirobisindane moiety (spiroTR-PBOs). After synthesizing a bulky and very rigid bis(amino)phenol monomer containing a spirobisindane moiety, we prepared spiroTR-PBOs and characterized their physical and mechanical properties along with their gas transport properties. We also performed molecular dynamic simulation studies of spiroTR-PBO membranes to gain further insight into their molecular behavior. 


\subsection{Experimental section}

\subsubsection{Materials}

Solvents and reactants were of reagent-grade quality and used without further purification. Bisphenol-A, 99\% anhydrous $N$-methyl-2-pyrrolidone (NMP),methanesulfonic acid, 45\% nitric acid, hydrazine monohydrate, and palladium $10 \mathrm{wt} \%$ on activated carbon were purchased from Sigma-Aldrich (St. Louis, USA). 4,4'-Hexafluoroisopropylidene diphthalic anhydride

(6FDA), 3,3',4,4'-bisphenyltetracarboxylic dianhydride (BPDA), 4,4'-(4,4'isopropylidenediphenoxy)bis(phthalic anhydride) (BPADA), and 1,2,3,5benzenetetracarboxylic anhydride (PMDA) were purchased from Daikin Industries, Ltd. (Osaka, Japan). The monomers were dried at 160 or $120^{\circ} \mathrm{C}$ under reduced pressure for $12 \mathrm{hr}$ before use.

\subsubsection{Synthesis of Monomer}

Spirobisindane-containing bis(amino)phenol was synthesized according to methods reported in the literature[32, $\underline{33}]$. Scheme 1shows the synthesis of monomer.

\subsubsection{3,3,3',3'-Tetramethyl-1,1'-spirobisindane-6,6'-diol (1)}

A mixture of bisphenol-A (200 g) and methanesulfonic acid (10 g) was heated at $140^{\circ} \mathrm{C}$ for $5 \mathrm{~h}$ leading to a molten reaction mixture, which was poured into $2 \mathrm{~L}$ of deionized water under constant stirring. The precipitate was filtered and rinsed extensively with water. The dried crude material was crystallized from aq. ethanol (60 g, 30\%, mp: $\left.216-218^{\circ} \mathrm{C}\right)$. 


\subsubsection{3,3,3',3'-Tetramethyl-1,1'-spirobisindane-5,5'dinitro-6,6'-diol (2)}

$\mathrm{HNO}_{3}(45 \%)$ (8 mL) was added dropwise to $2 \mathrm{~g}$ of crystallized material 1 (2 g, $\left.6.48 \mathrm{mmol}\right)$ at $0^{\circ} \mathrm{C}$. The semisolid yellow mixture was stirred overnight. Water was added and the solid was

filtered, washed with water, filtered, and desiccated, then chromatographed on silica gel using a gradient of hexane/ether (start 90:10, finish 70:30), (0.954 g, 37\%). ${ }^{1} \mathrm{H}$ NMR (400 MHz, DMSO) $\delta$ ) 10.59 (s, 1H), 7.91 (s, 1H), 6.54 (s, 1H), 2.42 (d, $J=13.2 \mathrm{~Hz}, 1 \mathrm{H}), 2.29$ (d, $J=13.2$ Hz, 1H), 1.44 (s, 3H), 1.37 (s, 3H); HR-MS calcd for $\mathrm{C}_{21} \mathrm{H}_{22} \mathrm{~N}_{2} \mathrm{O}_{6}$ 398.1477, found 398.1490.

\subsubsection{3,3,3',3'-Tetramethyl-1,1'-spirobisindane-5,5'diamino-6,6'-diol (3)}

The yellow solid 2 (10 g) was dispersed in ethanol (200 mL) followed by mixing with $\mathrm{Pd} / \mathrm{C}$ (0.8 g), which was heated to reflux. Then, $\mathrm{N}_{2} \mathrm{H}_{4}-\mathrm{H}_{2} \mathrm{O}(80 \%, 20 \mathrm{~mL})$ was added dropwise to the hot solution. After refluxing for $10 \mathrm{~h}$, the precipitate was taken off by filtration and the solution was cooled to room temperature, $200 \mathrm{~mL}$ of water was added, and the white precipitate was collected. The solid was recrystallized in ethanol and dried under vacuum, and finally white powder 3 was obtained (9.4 g, 96\%). ${ }^{1} \mathrm{H}$ NMR (400 MHz, DMSO) $\delta$ ) 8.66 (s, 2H), 6.31 (s, 2H), 6.03 (s, 2H), 4.31 (s, 4H), 2.15 (d, $J=12.9 \mathrm{~Hz}, 2 \mathrm{H}), 1.99$ (d, $J=12.9 \mathrm{~Hz}, 2 \mathrm{H}), 1.25$ (s, 6H), 1.20 (s, 6H); HR-MS calcd for $\mathrm{C}_{21} \mathrm{H}_{26} \mathrm{~N}_{2} \mathrm{O}_{2} 338.20$, found 338.14 


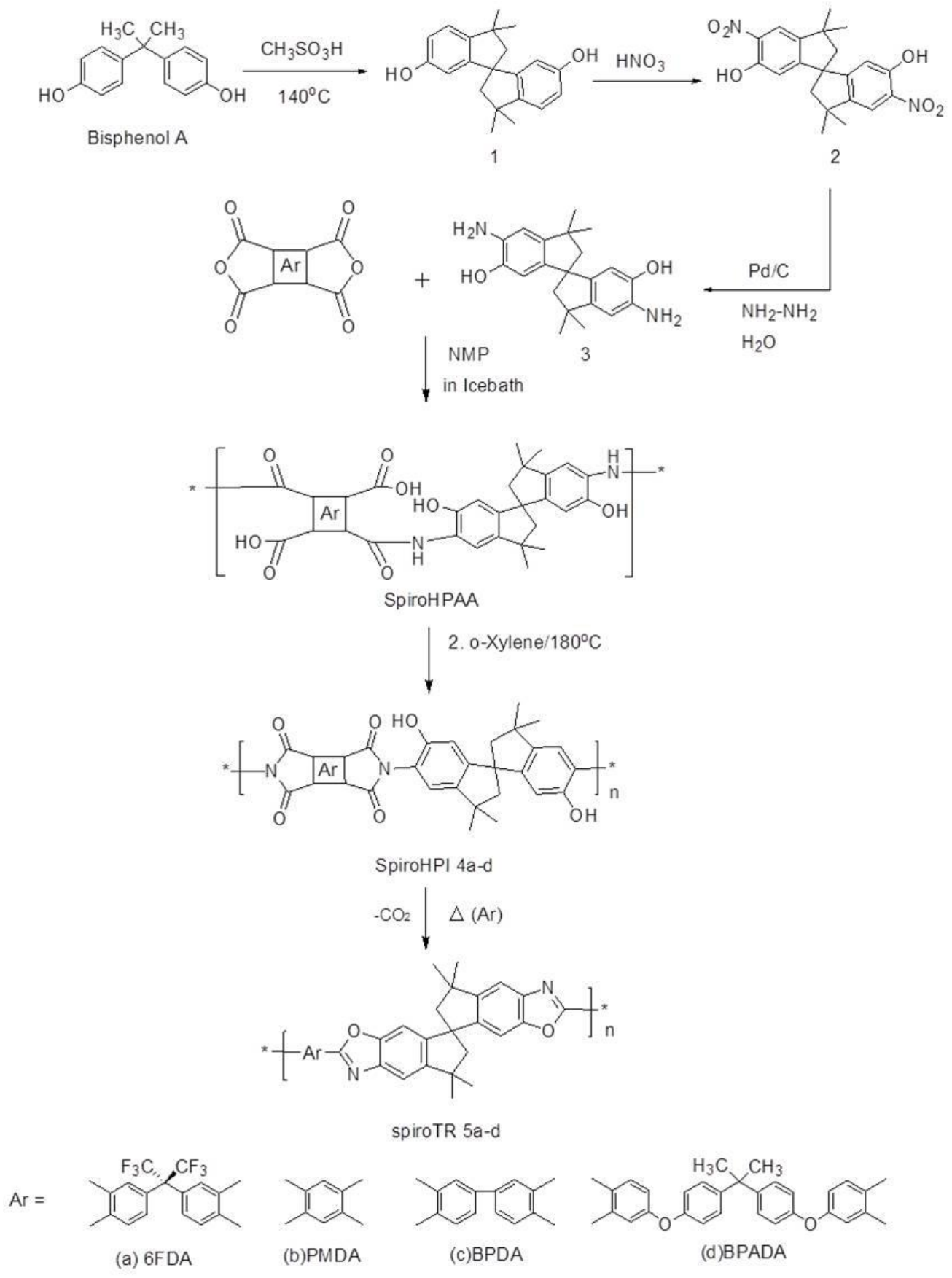

Scheme 4-1 Preparation of spirobisindane-containing hydroxyl polyimides (spiroHPIs) by azeotropicimidization and their thermally rearranged polybenzoxazoles (spiroTR-PBOs) 


\subsubsection{Synthesis of spiro-hydroxyl polyimides via poly(amic acid)}

A two-step azeotropic imidization process was used to obtain spiro-hydroxyl polyimide (spiroHPI) powders (Scheme 1) as described in our previous studies[26, 28].All pre-treated chemicals and glassware were placed in a glove box and purged with dried nitrogen to protect monomers from moisture. 3 (10 mmol) as a diamine was dissolved in a $250 \mathrm{~mL}$ three-neck round-bottomed flask filled with NMP (30 mL). After stirring for $1 \mathrm{~h}$ under a nitrogen atmosphere, $10 \mathrm{mmol}$ of a dianhydride (6FDA, BPDA, PMDA, or BPADA) was slowly added to the solution followed by stirring for $3 \mathrm{~h}$ in an ice bath, which induced the spontaneous ringopening reaction of dianhydride with diamine. This process yielded a yellowish spirobisindane-

containing hydroxyl poly(amic acid) (spiroHPAA) solution as an intermediate of polyimide. A round-bottomed flask containing intermediate spiroHPAA solution in NMP was moved into an oil bath with a temperature controller and connected to a Dean-Stark trap with a watercirculated condenser. $o$-Xylene $(30 \mathrm{~mL})$ as an azeotropic agent was added to the solution, which was stirred vigorously and heated. The oil bath was heated slowly to $180^{\circ} \mathrm{C}$. While $o$-xylene was kept refluxing for 6hr, water was separated by condensation in the trap. The resulting brownish solution was cooled to room temperature, precipitated in distilled water, and then dried at $150^{\circ} \mathrm{C}$ for $12 \mathrm{~h}$.

\subsubsection{6FDA-based hydroxy polyimide containing spirobisindane (4a)}

${ }^{1} \mathrm{H}$ NMR (300 MHz, DMSO-d $)_{\text {) }} 9.62$ (s, 2H, OH), 8.14 (d, 2H, J=8.0 Hz), 7.96 (d, 2H, J=8.0 Hz), 7.76 (s, 2 H), 7.16 (s, 2 H), 6.64(s, 2H), 2.48 (d, 4H, J = 12.9 Hz), 1.35(s, 6H), 1.30(s, 6H). FT-IR (film): $v(-\mathrm{OH})$ at $3460 \mathrm{~cm}^{-1}, v(\mathrm{C}-\mathrm{H})$ at $2950 \mathrm{~cm}^{-1}$, imide $v(\mathrm{C}=\mathrm{O})$ at 1786 and $1720 \mathrm{~cm}^{-1}$, imide $v(\mathrm{C}-\mathrm{N})$ at $1380 \mathrm{~cm}^{-1}$. Molecular weight: $\mathrm{M}_{\mathrm{w}}=69,600, \mathrm{M}_{\mathrm{n}}=21,500$ with 
a polydispersity of 3.5 .

\subsubsection{PMDA-based hydroxy polyimide-containing spirobisindane (4b)}

${ }^{1} \mathrm{H}$ NMR (300 MHz, DMSO-d 6 ): 9.75 (s, 2H, OH), 8.34 (s, 2H,), 7.22 (s, 2H), 6.51 (s, 2 H), $2.49(\mathrm{~d}, 4 \mathrm{H}, \mathrm{J}=12.9 \mathrm{~Hz}), 1.35(\mathrm{~s}, 6 \mathrm{H}), 1.30(\mathrm{~s}, 6 \mathrm{H})$. FT-IR (film): $v(-\mathrm{OH})$ at $3395 \mathrm{~cm}^{-1}, v(\mathrm{C}-$ $\mathrm{H})$ at $2939 \mathrm{~cm}^{-1}$, imide $v(\mathrm{C}=\mathrm{O})$ at 1778 and $1724 \mathrm{~cm}^{-1}$, imide $v(\mathrm{C}-\mathrm{N})$ at $1377 \mathrm{~cm}^{-1}$. Molecular weight: $\mathrm{Mw}=59,100, \mathrm{Mn}=16,100$ with a polydispersity of 3.6 .

\subsubsection{BPDA-based hydroxy polyimide-containing spirobisindane (4c)}

${ }^{1} \mathrm{H}$ NMR (300 MHz, DMSO-d $\mathrm{d}_{6}$ ): 9.70 (s, 2H, OH), 8.41 (d, 2H, J=8.0 Hz), 8.35 (s, 2H), 8.06 (s, 2H), 7.19 (s, 2H), 6.51(s, 2H), 2.48 (d, 4H, J = 12.9 Hz), 1.35(s, 6H), 1.30(s, 6H). FTIR (film): $v(-\mathrm{OH})$ at $3398 \mathrm{~cm}^{-1}, v(\mathrm{C}-\mathrm{H})$ at $2950 \mathrm{~cm}^{-1}$, imide $v(\mathrm{C}=\mathrm{O})$ at 1778 and $1712 \mathrm{~cm}^{-1}$, imide $v(\mathrm{C}-\mathrm{N})$ at $1380 \mathrm{~cm}^{-1}$. Molecular weight: $\mathrm{Mw}=104,000, \mathrm{Mn}=26,200$ with a polydispersity of 3.9.

\subsubsection{BPADA-based hydroxy polyimide-containing spirobisindane (4d)}

${ }^{1} \mathrm{H}$ NMR (300 MHz, DMSO-d $)$ ): 9.58 (s, 2H, OH), 7.89 (s, 2H), 7.46 (d, 10H), 7.18 (d, 4H), 6.46(s, 2H), 2.48 (d, 4H, J = $12.9 \mathrm{~Hz}), 1.35(\mathrm{~s}, 6 \mathrm{H}), 1.30(\mathrm{~s}, 6 \mathrm{H})$. FT-IR (film): $v(-\mathrm{OH})$ at $3425 \mathrm{~cm}^{-1}, v(\mathrm{C}-\mathrm{H})$ at $2939 \mathrm{~cm}^{-1}$, imide $v(\mathrm{C}=\mathrm{O})$ at 1778 and $1716 \mathrm{~cm}^{-1}$, imide $v(\mathrm{C}-\mathrm{N})$ at 1380 $\mathrm{cm}^{-1}$. Molecular weight: $\mathrm{Mw}=94,600, \mathrm{Mn}=24,000$ with a polydispersity of 3.9.

\subsubsection{Preparation of spiroTR-PBO membranes}

SpiroHPIs were dissolved in $20 \mathrm{wt} \%$ NMP solution and cast onto clean glass plates after filtering with a $10 \mu \mathrm{m}$ pore size glass filter. The glass plates were placed in a vacuum oven and 
slowly heated from 60 to $250^{\circ} \mathrm{C}$, with a $1 \mathrm{hr}$ hold at $100,150,200$, and $250^{\circ} \mathrm{C}$ to evaporate solvent. The yellow membranes were removed in a hot water bath, washed with deionized water, and dried at $120^{\circ} \mathrm{C}$ for $12 \mathrm{hr}$. Membranes $(5 \times 5 \mathrm{~cm})$ were placed in a muffle furnace with a Eurotherm controller, heated up to $300^{\circ} \mathrm{C}$ at a rate of $5^{\circ} \mathrm{C} / \mathrm{min}$, and maintained at this temperature for $30 \mathrm{~min}$ in order to fully imidize the membranes. To obtain fully converted polybenzoxazoles from spiroHPIs, a further thermal treatment was performed at 400,425 , or $450^{\circ} \mathrm{C}$ depending on the chemical structure of each spiroHPI.

Thermal protocols for spiroTR-PBO membranes were determined by isothermal TGA studies to obtain $100 \%$ conversion from spiroHPIs to spiroTR-PBOs. The specific thermal protocols for each membrane will be discussed later. Samples were coded as spiroHPI-xx or spiroTR-PBO-xx where xx indicates the type of anhydride (6F, PM, BP or BPA).

\subsubsection{Measurements}

A novel synthesized bis(amino)phenol containing spirobisindane monomer and several spiroHPI structures were confirmed by ${ }^{1} \mathrm{H}$ nuclear magnetic resonance $\left({ }^{1} \mathrm{H}-\mathrm{NMR}\right)$ spectra recorded on a Mercury Plus $300 \mathrm{MHz}$ spectrometer (Varian, Inc., Palo Alto, CA, USA). SpiroHPIs and spiroTR-PBO structures were confirmed by ${ }^{13} \mathrm{C}$ nuclear magnetic resonance $\left({ }^{13} \mathrm{C}-\mathrm{NMR}\right)$ spectra in a solid state using a $500 \mathrm{~Hz}$, Bruker Avance II (Bruker Biospin Inc., Billerica, MA, USA). Molecular weight of each synthesized spiroHPI was measured by gel permeation chromatography (Waters GPC system, Milford, MA, USA). Thermo-gravimetric analysis (TGA) coupled with mass spectroscopy (MS) was used to confirm thermal 
rearrangements and rearrangement temperatures using a TGA Q50 instrument (TA Instrument, $\mathrm{DE}$, USA) at a heating rate of $10{ }^{\circ} \mathrm{C} / \mathrm{min}$ under high purity nitrogen purging with a Thermostar ${ }^{\mathrm{TM}}$ GSD 301T (Pfeiffer Vacuum GmbH, Asslar, Germany).

Mechanical properties of spiroHPIs and spiroTR-PBOs were measured using a Universal Testing Machine, UTM (AGS-J, Shimadzu, Kyoto, Japan) with specimens prepared according to ASTM D638-Type5 recommendations. At least four specimens of each sample were measured and the standard deviation from the mean was less than $\pm 10 \%$. Wide-angle X-ray diffractometry (WAXD) (Rigaku Denki D/MAX-2500, Rigaku, Japan) provided the intermolecular distances of the spiroHPI precursors and spiroTR-PBO membranes. Sorption characteristics with respect to nitrogen were measured at $77 \mathrm{~K}$ using a surface area and porosimetry analyzer (ASAP 2020, Micrometrics Instrument Corp., Norcross, GA, USA) after degassing finely ground samples at $300^{\circ} \mathrm{C}$ for $6 \mathrm{~h}$. The fractional free volume $\left(F F V, V_{\mathrm{f}}\right)$, which is an important determinant of transport behavior through polymer membranes, was calculated from the densities measured using a Sartorius MS02255-DU (Sartorius AG, Goettingen, Germany) balance with a density kit and buoyancy method using 2,2,4-trimethylpentane as immersion medium as follows

$$
\begin{gathered}
V_{0}=1.3 V_{\mathrm{w}} \\
V=\frac{\mathrm{M}}{\rho} \\
V_{\mathrm{f}}=\frac{V-V_{0}}{V}
\end{gathered}
$$

Where $V$ is the molar volume of the polymer $\left(\mathrm{cm}^{3} / \mathrm{mol}\right)$ derived from the density $\rho\left(\mathrm{g} / \mathrm{cm}^{3}\right)$ 
and the molar mass of the repeat unit $M(\mathrm{~g} / \mathrm{mol}) . V_{\text {wis }}$ the van der Waals molar volume based on Bondi's group contribution theory.

Gas permeation properties were measured using the timelag method with a lab-made instrument for $\mathrm{He}(0.26 \mathrm{~nm}), \mathrm{H}_{2}(0.29 \mathrm{~nm}), \mathrm{CO}_{2}(0.33 \mathrm{~nm}), \mathrm{O}_{2}(0.35 \mathrm{~nm}), \mathrm{N}_{2}(0.36 \mathrm{~nm})$, and $\mathrm{CH}_{4}$ $(0.38 \mathrm{~nm})$ at a feed pressure of 760Torrdownstream pressure in a fixed chamber volume was increased from 0 to 10Torr and gas permeability coefficientsand ideal gas selectivity were calculated by the following equations:

$$
\begin{gathered}
P=D \cdot S=\frac{273.15 \times \mathrm{VL}}{76 \times P_{2} \mathrm{AT}}\left(\frac{\mathrm{d} P_{1}}{\mathrm{dt}}\right) \\
\alpha_{A / B}=\frac{P_{A}}{P_{B}}=\frac{D_{A}}{D_{B}} \cdot \frac{S_{A}}{S_{B}}=\alpha_{A / B}^{\mathrm{D}} \cdot \alpha_{A / B}^{\mathrm{S}}
\end{gathered}
$$

Here, $P$ (Barrer) is the gas permeability, $V\left(\mathrm{~cm}^{3}\right)$ is the downstream chamber volume, $L$ $(\mathrm{cm})$ is the thickness of the membrane, $P_{2}(\mathrm{cmHg})$ is upstream pressure (when downstream pressure is sufficiently low as to be negligible), $T(\mathrm{~K})$ is temperature, $A\left(\mathrm{~cm}^{2}\right)$ is the effective area of membraneand $d P_{l} / d t$ is the rate of the pressure rise in downstream chamber at steady state. $\alpha_{A / B}$ is the ideal gas selectivity and also defined as the product of diffusion selectivity $\left(\alpha^{D}{ }_{A / B}\right)$ and solubility selectivity $\left(\alpha_{A / B}^{S}\right)$.

The sorption isotherms of small gases into spiroTR-PBO-6F and spiroHPI-6F were measured with a pressure decay method at pressures up to around 20 atm depending on the penetrate gases.[34] The gas solubility was calculated from the pressure decay using the equation of state. A compressibility factor and a fugacity coefficient were introduced to apply the equation of state to real gas molecules. Solubility measurement was performed in the order 
of $\mathrm{H}_{2}, \mathrm{O}_{2}, \mathrm{~N}_{2}, \mathrm{CH}_{4}$, and $\mathrm{CO}_{2}$ to prevent plasticization effect due to $\mathrm{CO}_{2}$. The sorption measurement was performed at $35^{\circ} \mathrm{C}$ in a water bath.

Molecular dynamic (MD) simulations were carried out with a time step of 1.0 fs to equilibrate the cells and obtain the final stable structures. The Berendsen algorithm set to a decay constant of 0.1 ps was used to control the temperature and pressure of each cell. Specific MD simulation procedures were as follows: (1) a NPT (a constant particle number, pressure and temperature) MD simulation at $400 \mathrm{~K}$ and 1 bar for 50 ps, (2) a NPT MD simulation at 298 K and 1 bar for 50 ps, (3) a NVT (a constant particle number, volume and temperature) MD simulation at $298 \mathrm{~K}$ for $10 \mathrm{ps,} \mathrm{(4)} \mathrm{a} \mathrm{NPT} \mathrm{MD} \mathrm{simulation} \mathrm{at} 298 \mathrm{~K}$ and 10000 bar for $50 \mathrm{ps,} \mathrm{(5)}$ a NVT MD simulation at $600 \mathrm{~K}$ for $20 \mathrm{ps,} \mathrm{(6)} \mathrm{a} \mathrm{NVT} \mathrm{MD} \mathrm{simulation} \mathrm{at} 298 \mathrm{~K}$ for $20 \mathrm{ps}$ and (6) a NPT MD simulation at $298 \mathrm{~K}$ and 1 bar for 50 ps. Simulations (4) - (7) were repeated until the simulated density and density changing rates had converged to within $3 \%$. Finally, a NVT MD simulation was performed at $298 \mathrm{~K}$ for 10 ps to produce the spiroTR-PBO models. The Ewald summation method was used to calculate non-bond interactions (electrostatic and van der Waals) with an accuracy of $0.01 \mathrm{kcal} / \mathrm{mol}[\underline{27}]$. 


\subsection{Results and Discussion}

\subsubsection{Synthesis of monomer, spiroHPIs and spiroTR-PBO membranes}

${ }^{1} \mathrm{H}-\mathrm{NMR}$ results of monomer $\mathbf{3}$ and spiroHPIs showed that the monomer and spiroHPIs were successfully synthesized (Figure 4-1). Hydroxyl polyimides rearranged to polybenzoxazole by decarboxylation, induced by thermal treatment in the temperature range $350-450{ }^{\circ} \mathrm{C}[\underline{6}, \underline{24}, \underline{25}, \underline{28}, \underline{35}, \underline{36}]$. Molecular weights of spiroHPIs ranged between 60 and $100 \mathrm{kDa}$ (Table 4-1). Solubilities of spiroHPIs were very similar to HPIs.

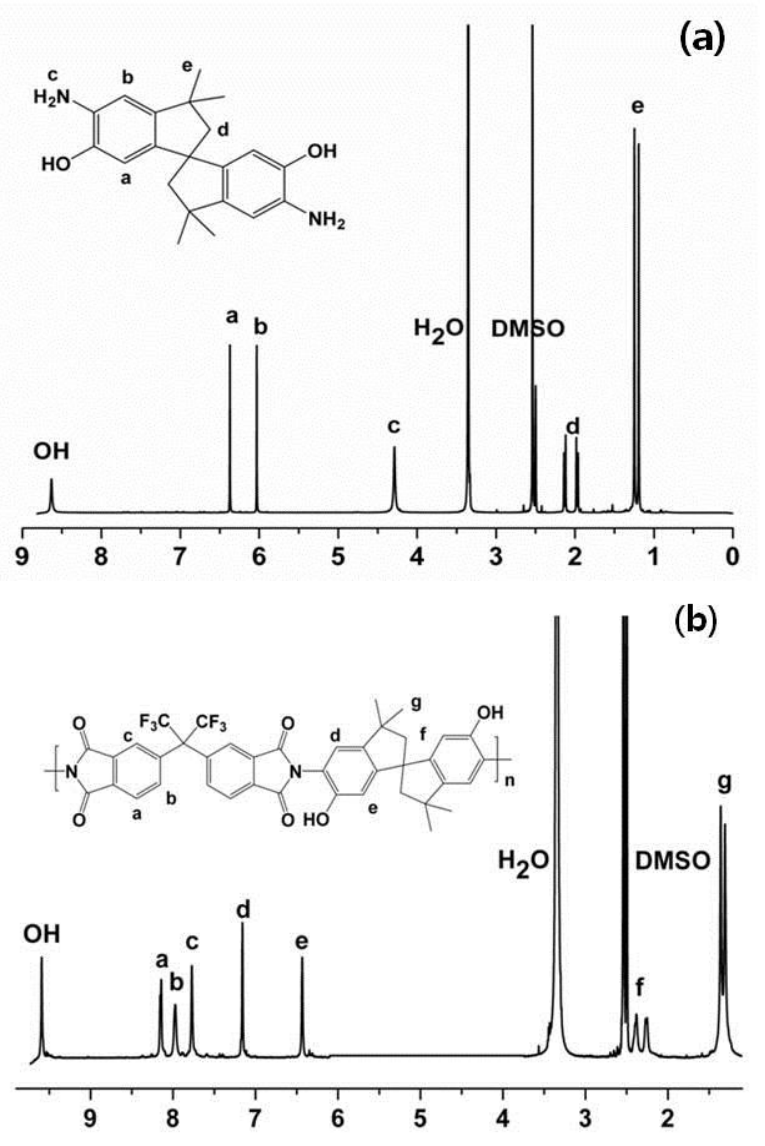

Figure 4-1 Typical 1H-NMR of (a) 3,3,3',3'-Tetramethyl-1,1'-spirobisindane-5,5' diamino- 
6,6'-diol monomer and (b) spiroHPI-6F.

Table 4-1 Molecular weight and solubility of precursor spiroHPIs

\begin{tabular}{|c|c|c|c|c|c|c|c|c|c|}
\hline \multirow{2}{*}{ Polymer } & Mn & \multirow{2}{*}{ Mw } & \multicolumn{7}{|c|}{ Solubility/Solvent $^{a}$} \\
\cline { 4 - 10 } & & NMP & DMAc & DMSO & THF & Acetone & MeOH & EtOH \\
\hline $\begin{array}{c}\text { spiroHPI } \\
\text {-6F }\end{array}$ & 19700 & 69600 & ++ & ++ & ++ & ++ & ++ & + & + \\
\hline $\begin{array}{c}\text { spiroHPI } \\
\text {-PM }\end{array}$ & 16100 & 59100 & ++ & ++ & ++ & + & ++ & - & - \\
\hline $\begin{array}{c}\text { spiroHPI } \\
\text {-BP }\end{array}$ & 26200 & 104000 & ++ & ++ & ++ & + & ++ & - & - \\
\hline $\begin{array}{c}\text { spiroHPI } \\
\text {-BPA }\end{array}$ & 24000 & 64600 & ++ & ++ & ++ & ++ & ++ & + & + \\
\hline
\end{tabular}

${ }^{a}$ NMP: N-methylpyrrolidinone; DMAc: N,N-dimethylacetamide; DMSO: dimethyl sulfoxide; THF: tetrahydrofura; $\mathrm{MeOH}$ : methanol; EtOH: ethanol; The solubility was determined at $5 \%$ polymer content.+ +: soluble; the solid polymer was completely dissolved in the solvent to afford a clean, homogenous solution.+: partially soluble; the solid polymer was partially soluble but was completely dissolved in solvent by heating. - -: insoluble; the solid polymer did not dissolve in the solvent.

A typical thermogravimetric diagram of spiroHPI-6F is shown in Figure 4-2(a). Decarboxylation of spiroHPIs was observed by TG-MS in the range $350-500{ }^{\circ} \mathrm{C}$. Degradation of the polymers occurred when they were heated over $500{ }^{\circ} \mathrm{C}$. Mass spectroscopy clearly revealed $\mathrm{CO}_{2}$ emission in the first weight loss region, indicating a decarboxylation reaction, and $\mathrm{H}_{2} \mathrm{O}$ emission by thermo-degradation.

TGA isothermal analysis was performed to determine the thermal treatment conditions for spiroHPIs in order to obtain completely rearranged spiroTR-PBO membranes. The understanding of thermal treatment conditions is fundamental because thermal treatment conditions affect the cavity size and free volume of the polymer.[ㅌ, 26] Typical examples of the TGA isotherms of spiroHPI-6F at $400,425,450{ }^{\circ} \mathrm{C}$ for $3 \mathrm{hr}$ are provided in Figure 4-2(b). If spiroHPI-6F isthermally converted to spiroTR-PBO-6F, the theoretical weight loss should be $11.8 \%$ based on the weight of one repeating unit of the polymer molecule. The $11.8 \%$ weight 
loss line crossed the $425{ }^{\circ} \mathrm{C}$ and $450{ }^{\circ} \mathrm{C}$ isothermal curves and matched well with 120 and 15 min, respectively. In this study, we selected a temperature of $425^{\circ} \mathrm{C}$ and a treatment time of 2 hr to obtain full conversion to spiroTR-PBO-6F. Thermal treatment conditions were determined in a similar manner for other fully converted TR-PBOs; the results are summarized in Table 4-2.
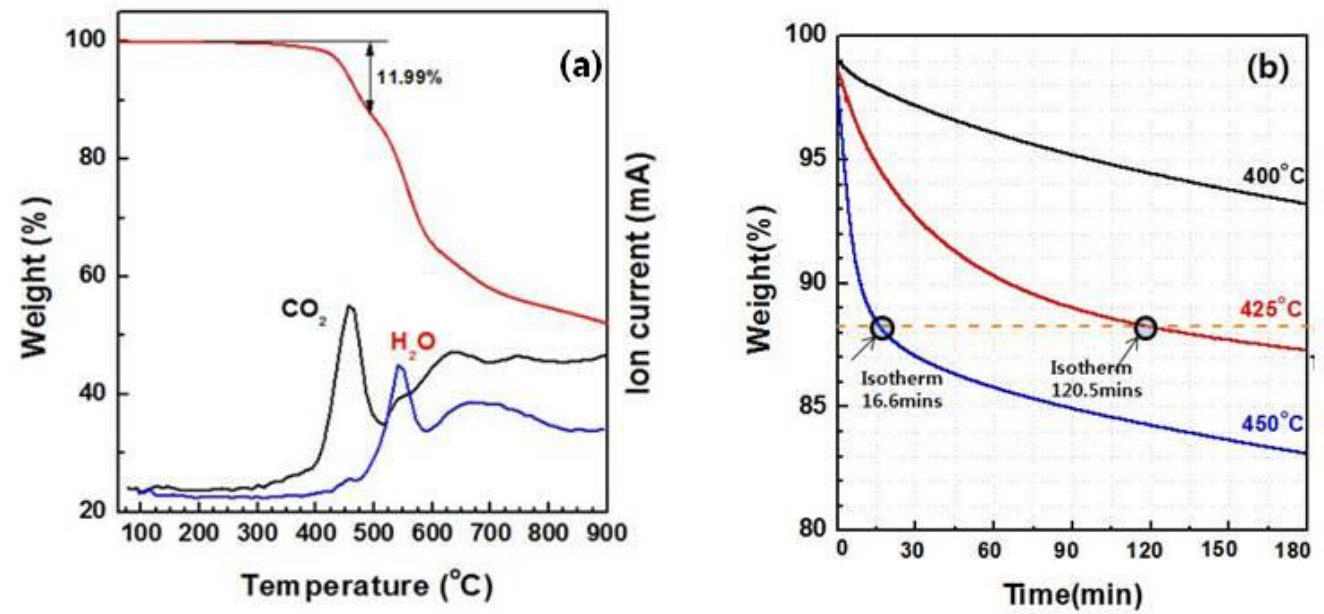

Figure 4-2 (a) Typical thermogravimetric analysis combined with mass spectroscopy (TG-MS) of spiroHPI-6F, and (b) isothermal TGA analysis of spiroHPI-6F at different temperatures

Typical solid-state ${ }^{13} \mathrm{C}$ NMR spectra of spiroHPI-6F and spiroTR-PBO-6F are presented in Figure 4-3. For the thermally rearranged polymer, peaks corresponding to the benzoxazole ring are present at 163 ppm and 107 ppm, consistent with the values reported in the literature[37]. 

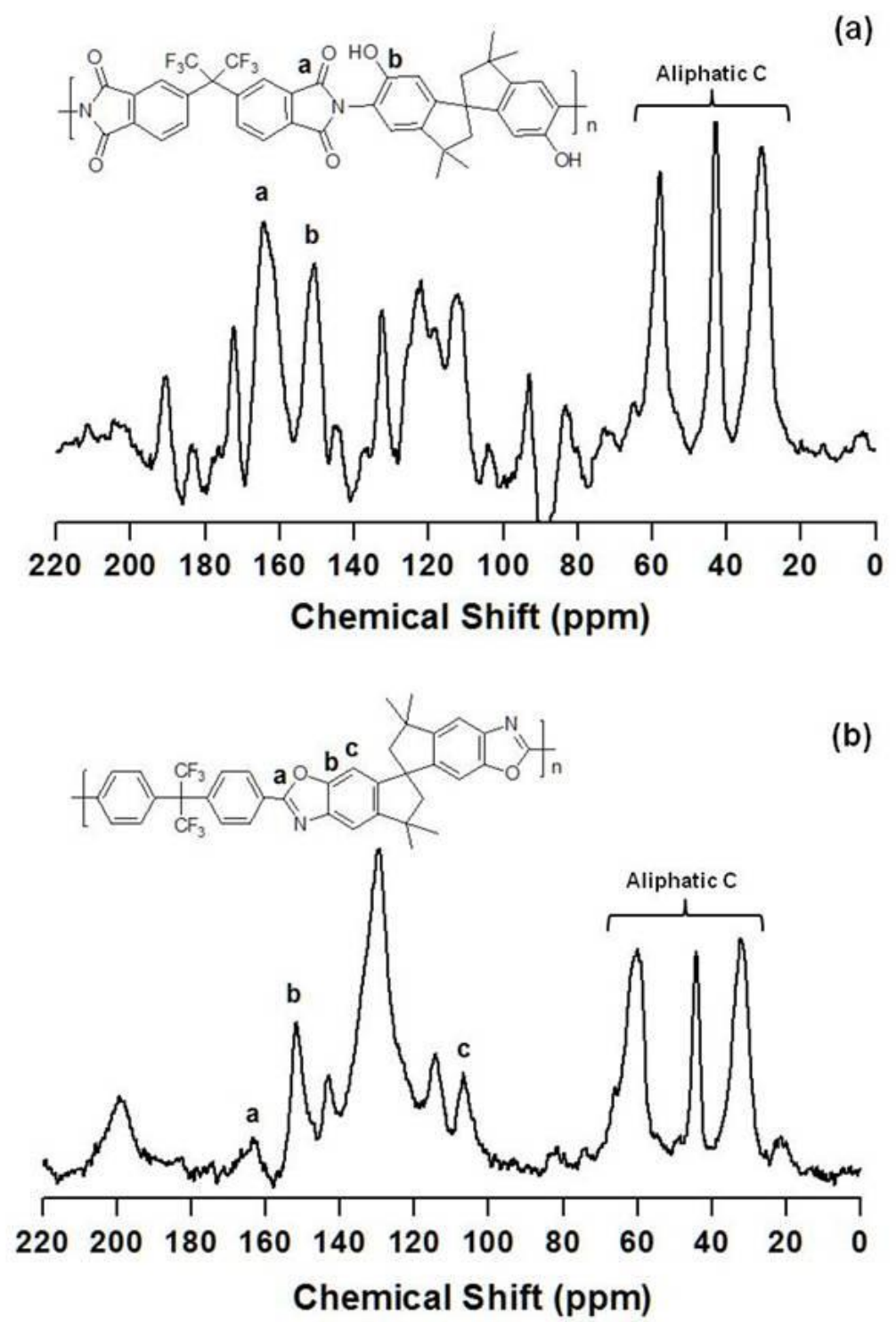

Figure 4-3 Typical ${ }^{13} \mathrm{C}-\mathrm{NMR}$ at power state of (a) spiroHPI-6F and (a) spiroTR-PBO-6F. 
Table 4-2 Theoretical weight loss of spiroHPIs and their thermal treatment conditions determined by isotherm TGA analysis.

Thermal treatment conditions

\begin{tabular}{lccc}
\cline { 2 - 4 } \multicolumn{1}{c}{ Polymer } & $\begin{array}{c}\text { Theoretical weight } \\
\text { loss } \\
(\%)\end{array}$ & $\begin{array}{c}\text { Temperature* } \\
\left({ }^{\circ} \mathrm{C}\right)\end{array}$ & $\begin{array}{c}\text { Time* } \\
(\mathrm{h})\end{array}$ \\
\hline spiroHPI-6F & 11.8 & 425 & 2.0 \\
spiroHPI-PM & 16.9 & 425 & 1.5 \\
spiroHPI-BP & 14.8 & 450 & 3.0 \\
spiroHPI-BPA & 10.7 & 400 & 1.0 \\
\hline
\end{tabular}

*Temperature and time to achieve the theoretical weight loss.

Figure 4-4 shows the ATR-FTIR spectra of four spiroHPIsandspiro TR-PBOs. All the spiroHPIs showed absorption bands at $1788 \mathrm{~cm}^{-1}$ (symmetric $\mathrm{C}=\mathrm{O}$ stretching), $1718 \mathrm{~cm}^{-1}$ (asymmetric $\mathrm{C}=\mathrm{O}$ stretching), and at $1373 \mathrm{~cm}^{-1}$ (C-N stretching), confirming the presence of imide groups. There was also a broad hydroxyl absorption band between 3200 and $3600 \mathrm{~cm}^{-1}$ and the methyl group of spirobisindane was confirmed in a band between 2800 and $3000 \mathrm{~cm}^{-1}$ (C-H stretching). No amide carbonyl peak at $1650 \mathrm{~cm}^{-1}$ was present, indicating complete imidization during polycondensation. SpiroTR-PBOs can be identified by emergent benzoxazole absorption bands at $1059 \mathrm{~cm}^{-1}$ and $1558 \mathrm{~cm}^{-1}$ (C=N stretching), and the disappearance of the broad absorption band between $3200 \mathrm{~cm}^{-1}$ and $3600 \mathrm{~cm}^{-1}$ which was associated with $-\mathrm{OH}[\underline{35}, \underline{36}]$. For spiroHPI-6F and spiroHPI-BPA which have flexible linkage in the polymer chains, the $-\mathrm{OH}$ bands and $\mathrm{C}=\mathrm{O}$ bands almost completely disappeared on thermal treatment, indicating that the hydroxy polyimide structures of spiroHPIs were more or less fully converted to benzoxazole structures. On the other hand, the $-\mathrm{OH}$ bands and $\mathrm{C}=\mathrm{O}$ bands of spiroHPI-PM and spiroHPI-BP composed of rigid polymer structures, were not fully eliminated. 

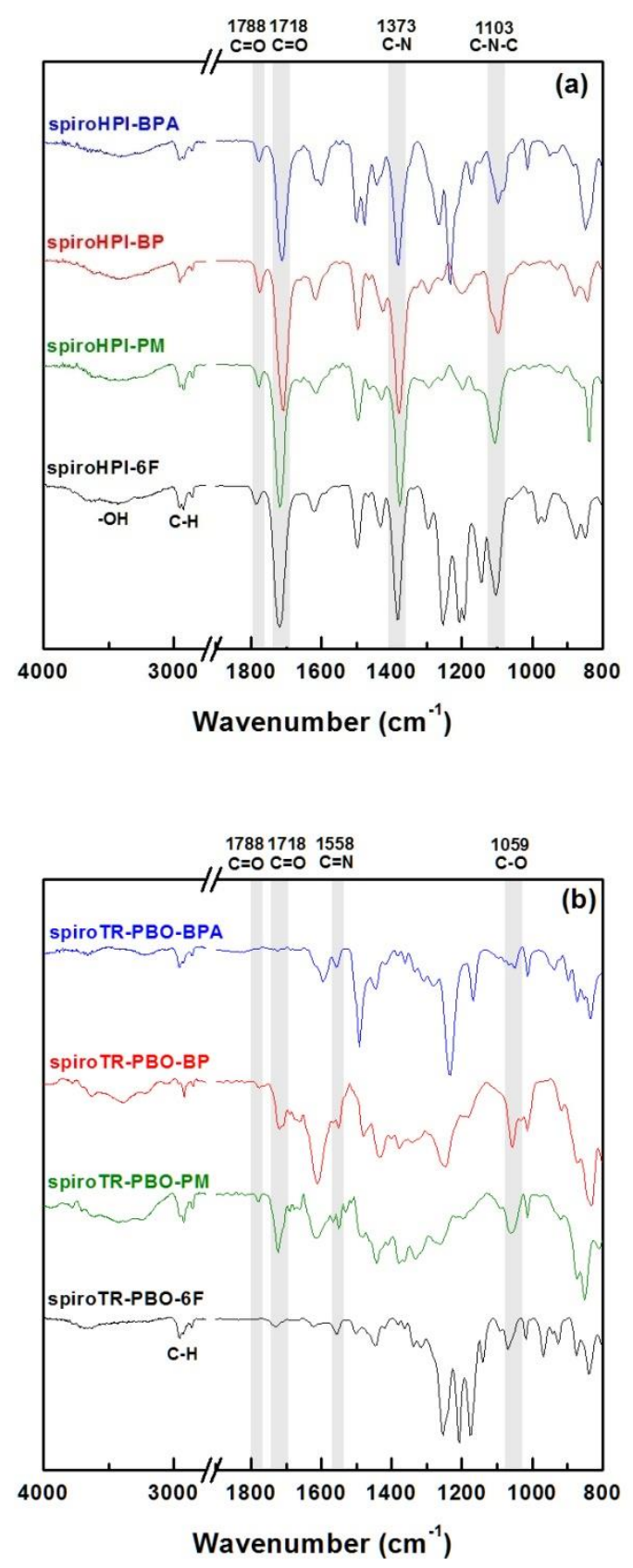

Figure 4-4 ATR-IR spectra of (a) spiroHPIs and (b) spiroTR-PBOs. 


\subsubsection{Physical properties}

Changes in the physical properties of spiroHPIs to spiroTR-PBOs can also prove the occurrence of thermal rearrangement reactions. We noticed that the thermal conversion from HPI to TR-PBO was accompanied by changes in physical properties such as density, $d$-spacing between polymer chains, and surface area[24, 28]. Two hydroxyl-functional polyimides with intrinsic microporosity were prepared by Ma et al.[22] and named as PIM-6FDA-OH and PIMPMDA-OH, which showed the same structure as spiroHPI-6F and PM. These two HPIs showed very similar physical properties to ours, even with different membrane preparation methods. The physical properties of spiroHPIs and spiroTR-PBOs with different chemical structures are summarized in Table 4-3. It is well known that the fractional free volume (FFV) of polymer increases during conversion from HPIs to TR-PBOs, resulting in a direct relationship with permeability [38]. SpiroTR-PBOs showed up to 31\% increase in fractional free volume after thermal rearrangement. The density of spiroTR-PBO-6F decreased from 1.27 to $1.12 \mathrm{~g} / \mathrm{cm}^{3}$ elevating the $F F V$ of spiroTR-PBO-6F up to 0.27 ; a $31 \%$ increment in $F F V$ compared with spiroHPI-6F. Note that the density of aPBO also decreased compared to that of aHPI, with a 29\% increase in $F F V(F F V=0.22)[\underline{28}]$. SpiroTR-PBO-PM showed only a 6\% increment in FFV due to high rigidity of spiroHPI-PM structure that restricted torsional strain to form high free volume. SpiroTR-PBO-BP, which contained a biphenyl bridge with a spiro-center, showed a $14 \%$ increment in $F F V$ from 0.17 to 0.20 . In contrast, spiroTR-PBO-BPA, which was prepared from BPADA, showed only a $3 \%$ increment in $F F V$. There might be a limitation to enhancing the $F F V$ of polymers by ether linkage of BPADA due to its high chain flexibility that fills up and stabilizes unoccupied free volume during thermal treatment. 
The maximum average distance between polymer chains, or the d-spacing, had the following rank order: spiroTR-PBO-6F (6.42 $\AA)$ > PM (5.52 $\AA)$ > BP $(5.30 \AA)$ > BPA (5.25 $\AA)$, which coincided well with the free volume changes. As shown in Table 4-3, the d-spacing of spiroTR-PBOs, except for spiroTR-PBO-BPA, increased when compared with that of the spiroHPIs; the d-spacing of spiroTR-PBO-BPA, which contained flexible ether linkages, decreased slightly.

Table 4-3 Physical properties of precursor spiroHPIs and spiroTR-PBOs.

\begin{tabular}{|c|c|c|c|c|c|c|c|}
\hline Polymer & $\begin{array}{l}\text { Density } \\
\left(\mathrm{g} / \mathrm{cm}^{3}\right)\end{array}$ & $\begin{array}{c}\mathrm{V}^{\mathrm{a}} \\
\left(\mathrm{cm}^{3} / \mathrm{mol}\right)\end{array}$ & $\begin{array}{c}\mathrm{V}_{\mathrm{w}} \\
\left(\mathrm{cm}^{3} / \mathrm{mol}\right)\end{array}$ & $\mathrm{FFV}^{\mathrm{b}}$ & $\begin{array}{c}\text { Increment } \\
\text { in FFV } \\
(\%)\end{array}$ & $\begin{array}{c}\text { d-spacing } \\
(\AA ̊)\end{array}$ & $\begin{array}{c}\text { BET } \\
\text { surface area } \\
\left(\mathrm{m}^{2} / \mathrm{g}\right)\end{array}$ \\
\hline spiroHPI-6F & 1.27 & 587 & 360 & 0.20 & - & 6.34 & 368 \\
\hline spiroHPI-PM & 1.18 & 441 & 280 & 0.21 & - & 5.42 & 377 \\
\hline spiroHPI-BP & 1.22 & 488 & 311 & 0.17 & - & 5.24 & 112 \\
\hline spiroHPI-BPA & 1.21 & 681 & 439 & 0.16 & - & 5.44 & 12 \\
\hline spiroTR-PBO-6F & 1.12 & 586 & 332 & 0.27 & 31 & 6.42 & 466 \\
\hline $\begin{array}{l}\text { spiroTR-PBO- } \\
\text { PM }\end{array}$ & 1.10 & 394 & 238 & 0.22 & 6 & 5.52 & 283 \\
\hline $\begin{array}{l}\text { spiroTR-PBO- } \\
\text { BP }\end{array}$ & 1.12 & 456 & 282 & 0.20 & 14 & 5.30 & 306 \\
\hline $\begin{array}{l}\text { spiroTR-PBO- } \\
\text { BPA }\end{array}$ & 1.15 & 640 & 410 & 0.17 & 3 & 5.25 & 4.7 \\
\hline
\end{tabular}

Nitrogen adsorption (at $\sim 77 \mathrm{~K}$ ) is widely used to determine the surface area and nanopore size distribution of porous solid materials. We found that the surface area measured by BET nitrogen sorption measurements matched very well with the $F F V$ increments. In this way, the surface area of spiroHPIs was noticeably high in the range of $100-370 \mathrm{~m}^{2} / \mathrm{g}$, whereas it was only $12 \mathrm{~m}^{2} / \mathrm{g}$ for spiroHPI-BPA. HPIs usually only have a surface area of about $10 \mathrm{~m}^{2} / \mathrm{g}$ but after conversion to TR-PBO, the surface area increases to $500 \mathrm{~m}^{2} / \mathrm{g}[\underline{28}]$. The high surface area of spiroHPIs-6F, PM and BP may be attributed to their rigid, contorted structures that result in 
inefficient chain packing, thereby maintaining the free volume. The BET surface area of PIMs was reported to range from 450-950 $\mathrm{m}^{2} / \mathrm{g}[\underline{19}, \underline{39}, \underline{40}]$, and TR-PBOs have been reported to have BET surface areas of $680-800 \mathrm{~m}^{2} / \mathrm{g}[\underline{6}, \underline{24}, \underline{25}]$.

Ether linkages in chemical structures inhibit porosity and decrease micropore volume because the freely movable ether moieties fill the void spaces in the polymers. After conducting a thermal treatment, the distance between polymer chains decreased for spiroTR-PBO-BPA, indicating an increasing an increase in chain packing of the polymer.

The nitrogen adsorption-desorption isotherm curves of spiroHPIs and spiroTR-PBOs in Figure 4-5 are mostly type II isotherms with a hysteresis at a low $\mathrm{P} / \mathrm{P}_{0}$ ratio, indicating significant micropore filling. This type of $\mathrm{N}_{2}$ adsorption behavior can be observed in microporous solid materials containing narrow slit-shaped pores[41]. The very broad hysteresis of spiroTR-PBO-6F in Figure 4-5(b) is likely due to the multi-throat cavity model characteristic of TR polymers. SpiroTR-PBO-PM and BP exhibited similar adsorption-desorption behavior. The isotherms for spiroHPI-BPA and spiroTR-PBO-BPA showed low uptake, typical of a nonporous powder. Figure 4-5(c) represents the simulated free volume distribution in TR-PBO$6 \mathrm{~F}$, which shows how free volume elements in an amorphous cell are dispersed. The size and distribution varied according to the type of TR-PBO. 

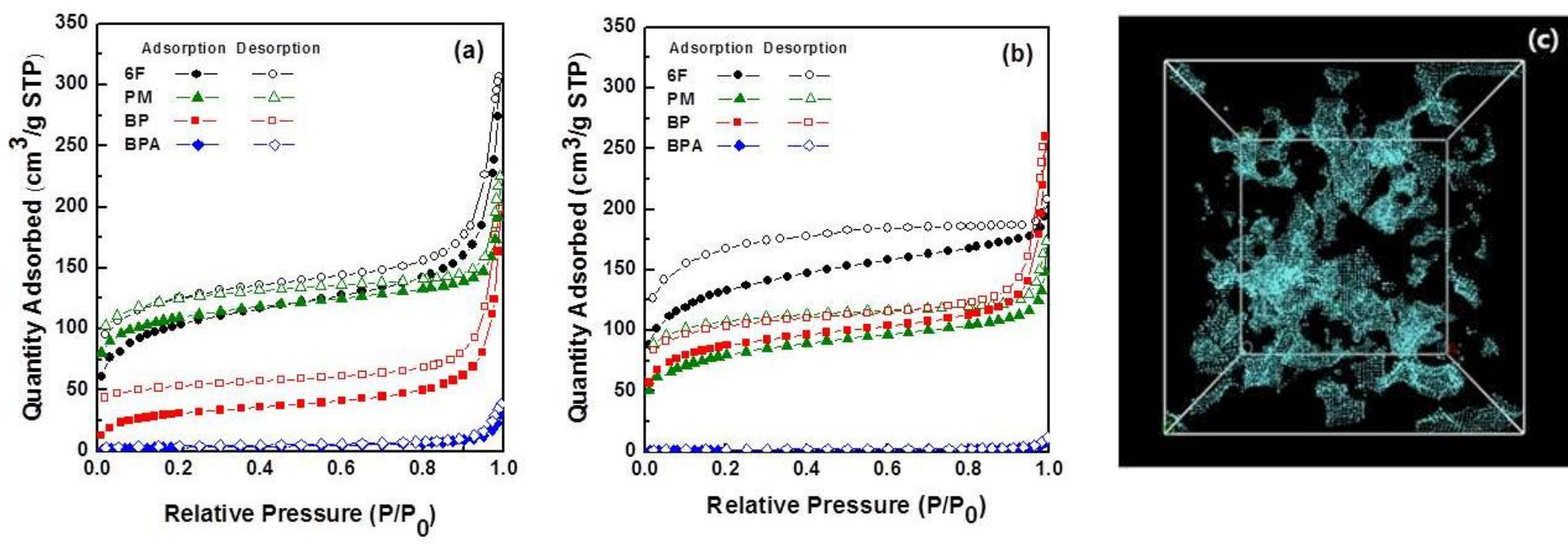

Figure 4-5 $\mathrm{N}_{2}$ sorption isotherms at $77 \mathrm{~K}$ of (a) spiroHPI and (b) spiroTR-PBO membranes. Filled symbols are the adsorption isotherm whereas open symbols are the desoprtion isotherms. (c) Typical simulated free volume (as represented inblue color) distribution in spiroTR-PBO-6F. 


\subsubsection{Mechanical properties}

The mechanical properties of materials determine their potential applications. Highly rigid microporous and nanoporous polymers do not usually show good mechanical properties because of their high porosity and free volume.The requirement for careful handling highlights the need for mechanically improved high free volume materials. The average tensile stength and elongation of the spiroTR-PBOs are summarized in Table 4-4, and the values for several polymeric microporous materials are also included for comparison[므, 42-44]. Surprisingly, spiroTR-PBOs showed high elongation at break, in the range of 15-20\%, despite the thermal treatment at high temperatures.We hypothesized that a degree of entanglement of molecular chains by the kink at the spiro center reduced the elongational stress. Moreover, PIM-1 showed lower elongation than spiroHPIs and spiroTR-PBOs, even though it had a spiro center, because of relatively non torsionable benzodioxane groups with a $180^{\circ}$ dihedral angle[45].These results indicate that spiroTR-PBOs havegood mechanical properties despitetheir high fractional freevolume, compared to other microporous polymers.

Figure 4-6 shows relationships between $F F V$ and elongation at break of spiroHPIs and spiroTR-PBOs, compared with glassy materials such as TR- polymers, PIM-1 and others. Generally, elongation of spiroHPIs and spiroTR-PBO were as high as those of polyether imides and polyimides. Again, spiroTR-PBO-6F and PM showed both high free volume and high elongation.As shown in Figure 4-6, high free volumeglassy polymers such as PIM-1 and TR1 generally show low flexibility because of their rigid sturcture. Common polyimides usually show high elongation at break but with low $F F V$, exhibiting low $\mathrm{CO}_{2}$ permeability $(<10$ Barrer). 


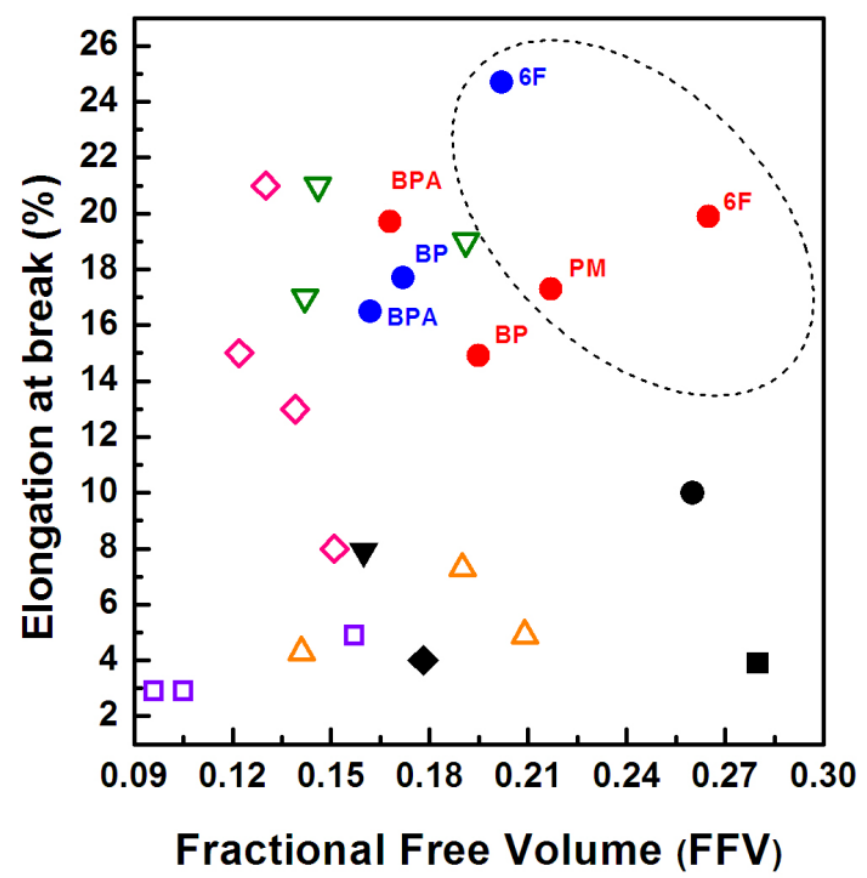

Figure 4-6 Relationship of elongation at break and fractional free volume (FFV) of various glassy polymers; spiroTR-PBOs $(\bullet)$, and spiroHPIs $(\bullet)$, spiro-bisindane-containing poly(ether imide)s $(\square)$ [46], polynaphthalimide $(\Delta)$ [47], polyimides $(\diamond)$ [48,49], polyether imides $(\nabla)[50]$, AF $2400(\boldsymbol{\nabla})$ [44], TR-PEBO $(\diamond)$ [26], PIM-1 (•) [42] and TR-1-450 (•) [6]. The dashed ellipse indicates spiroHPI and spiroTR-PBOs having high fractional free volumeand high elongation at break. Details are shown in Table 4-4. 
Table 4-4 Mechanical properties and fractional free volume of glassy polymers.

\begin{tabular}{|c|c|c|c|c|}
\hline Sample & $\begin{array}{l}\text { Fractional Free } \\
\text { Volume }\end{array}$ & $\begin{array}{l}\text { Tensile Strength } \\
\text { (MPa) }\end{array}$ & Elongation (\%) & References \\
\hline spiroHPI-6F & 0.20 & $100.9 \pm 10.8$ & $24.7 \pm 10.4$ & This work \\
\hline spiroHPI-PM & 0.21 & $97.8 \pm 3.7$ & $44.4 \pm 7.7$ & This work \\
\hline spiroHPI-BP & 0.17 & $97.8 \pm 13.8$ & $17.7 \pm 5.5$ & This work \\
\hline spiroHPI-BPA & 0.16 & $91.5 \pm 5.1$ & $16.5 \pm 1.7$ & This work \\
\hline SpiroTR-PBO-6F & 0.27 & $82.3 \pm 1.3$ & $20.0 \pm 4.0$ & This work \\
\hline SpiroTR-PBO-PM & 0.22 & $79.2 \pm 3.5$ & $17.3 \pm 3.6$ & This work \\
\hline SpiroTR-PBO-BP & 0.19 & $94.4 \pm 1.4$ & $14.9 \pm 0.5$ & This work \\
\hline SpiroTR-PBO-BPA & 0.17 & $69.9 \pm 4.4$ & $19.7 \pm 0.2$ & This work \\
\hline 6FDA-PPD & 0.21 & 7.04 & 4.9 & [1] \\
\hline $\begin{array}{c}\text { Poly(pheylene-co- } \\
\text { naphtalimide)-50 }\end{array}$ & 0.14 & 91 & 4.3 & {$[2]$} \\
\hline $\begin{array}{c}\text { Spiro-biindane } \\
\text { containing fluorinated } \\
\text { poly(ether imide) } \\
\text { (PEI)-8a }\end{array}$ & 0.10 & $41.3 \pm 3.2$ & $2.9 \pm 0.3$ & {$[\underline{3}]$} \\
\hline PEI-8b & 0.16 & $59.6 \pm 3.6$ & $4.9 \pm 1.0$ & [3] \\
\hline PEI-8d & 0.11 & $38.0 \pm 2.5$ & $2.9 \pm 0.5$ & [3] \\
\hline TR-PEBO-450-1 & 0.18 & 54 & 4.0 & [4] \\
\hline $\begin{array}{l}\text { Poly(ether imide) } \\
\text { PMDA-ATFT }\end{array}$ & 0.15 & 112 & 21.0 & [ㄷ] \\
\hline BTDA-ATFT & 0.14 & 110 & 17.0 & [5] \\
\hline 6FDA-ATFT & 0.19 & 96 & 19.0 & [5] \\
\hline A-ODA & 0.13 & 168 & 21.0 & {$[\underline{6}]$} \\
\hline A-MDA & 0.12 & 112 & 15.0 & [6] \\
\hline B-ODA & 0.14 & 123 & 13.0 & [6] \\
\hline C-ODA & 0.15 & 102 & 8.0 & [6] \\
\hline PIM-1 & 0.26 & 47.8 & 10.0 & [7] \\
\hline TR-1-450 & 0.28 & 98 & 3.9 & {$[\underline{8}]$} \\
\hline AF 2400 & 0.16 & 26.4 & 7.9 & [9] \\
\hline
\end{tabular}


To determine the contribution of the spiro center to elongation of the main chain, we conducted molecular dynamic simulations of spiroTR-PBOs. Figure 4-7 shows the angle distributions of spiro segments in the simulated spiroTR-PBO model in comparisonwith hexafluoroisopropylidene (6F) segments of TR-PBO. Afterthermal conversion (i.e., changing of the rotatable imidelinkages into a benzoxazole ring) from HPI, there are no flexible segmentsto release the external stress in TR-PBO except for the $6 \mathrm{~F}$ segments,due to the coplanar propertyof the PBO ring.

Table 4-5 Mechanical properties of spiroTR-PBOs and microporous materials reported in the literature.

\begin{tabular}{cccc} 
Membrane & $\begin{array}{c}\text { Tensile strength } \\
\text { at break } \\
\text { [MPa] }\end{array}$ & $\begin{array}{c}\text { Elongation } \\
\text { at break } \\
{[\%]}\end{array}$ & References \\
& $82.3 \pm 1.3$ & $20.0 \pm 4.0$ & this work \\
\hline spiroTR-PBO-6F & $79.2 \pm 3.5$ & $17.3 \pm 3.6$ & this work \\
spiroTR-PBO-PM & $94.4 \pm 1.4$ & $14.9 \pm 0.5$ & this work \\
spiroTR-PBO-BP & $69.9 \pm 4.4$ & $19.7 \pm 0.2$ & this work \\
spiroTR-PBO-BPA & 47.8 & 10.0 & {$[42]$} \\
PIM-1 & 98 & 3.9 & {$[6]$} \\
TR-1-450 & 42 & 0.4 & {$[6]$} \\
CMS & 16.1 & 4.1 & {$[43]$} \\
PTMSN & 26.4 & 7.9 & {$[44]$} \\
AF 2400 & & &
\end{tabular}

Furthermore, the limited flexibilty of the $6 \mathrm{~F}$ segment causes poor elongation, particularly for processiblity, despite good tensile strength as an engineering plastic. However, introduction of spiro segments instead of 6F segments in the TR-PBO main chain yields a microporous membrane with both strength and flexibility. As shown in Figure 4-7, the spiro segments showed a wider angle distribution $\left(60^{\circ}-120^{\circ}\right)$ than the $6 \mathrm{~F}$ segments $\left(100^{\circ}-120^{\circ}\right)$, which indicates that the spiroTR-PBO chain is more flexible than the TR-PBO chain.In addition, spiro 
kink group may provide adequate entanglement between chains hindering the slippage of chains and increases the elongation at break.

\section{Spiro segment}
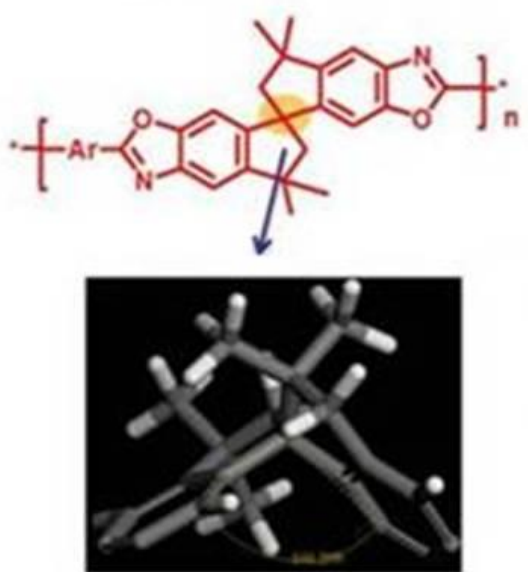

$-\mathrm{C}\left(\mathrm{CF}_{3}\right)_{2}$ - segment
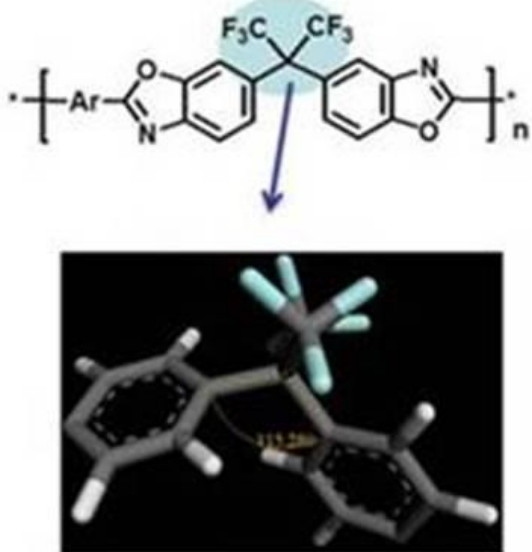

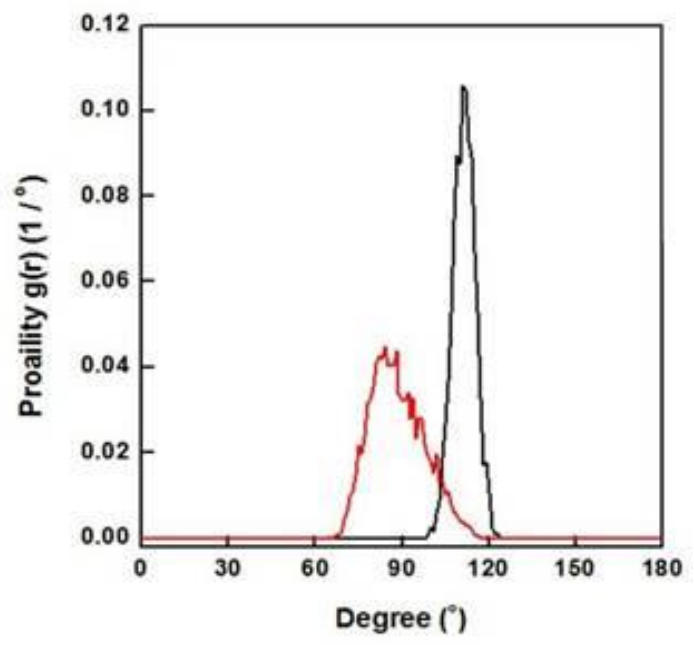

Figure 4-7 Angle distribution of the hexafluoroisopropylidene (-C(CF3)2-) segment in TRPBO (一) and spiro segments in spiroTR-PBO-6F (-). 
Table 4-6 Summary of gas permeability coefficient (P), diffusion coefficient (D), solubility coeffecient $(\mathrm{S})$, diffusion selectivity $(\alpha \mathrm{D})$, and solubility selectivity $(\alpha \mathrm{S})$ for spiroTR-PBO-6F, comparing with those of spiroHPI-6F, PIM-1 and aPBO.

\begin{tabular}{|c|c|c|c|c|c|c|c|c|c|c|c|c|c|}
\hline \multirow{2}{*}{ Membrane } & \multicolumn{3}{|c|}{$\begin{array}{c}P \\
\text { (Barrer) }\end{array}$} & \multicolumn{3}{|c|}{$\begin{array}{c}D^{a} \\
\left(10^{-8} \mathrm{~cm}^{2} / \mathrm{s}\right)\end{array}$} & \multicolumn{3}{|c|}{$\begin{array}{c}S^{b} \\
\left(10^{-2} \mathrm{~cm}^{3} / \mathrm{cm}^{3}\right. \\
\mathrm{cmHg})\end{array}$} & \multicolumn{2}{|c|}{$\alpha_{D}$} & \multicolumn{2}{|c|}{$\alpha_{\mathrm{s}}$} \\
\hline & $\mathrm{N}_{2}$ & $\mathrm{CH}_{4}$ & $\mathrm{CO}_{2}$ & $\mathrm{~N}_{2}$ & $\mathrm{CH}_{4}$ & $\mathrm{CO}_{2}$ & $\mathrm{~N}_{2}$ & $\mathrm{CH}_{4}$ & $\mathrm{CO}_{2}$ & $\begin{array}{l}\mathrm{CO}_{2} \\
/ \mathrm{N}_{2}\end{array}$ & $\begin{array}{l}\mathrm{CO}_{2} \\
/ \mathrm{CH}_{4}\end{array}$ & $\begin{array}{l}\mathrm{CO}_{2} \\
/ \mathrm{N}_{2}\end{array}$ & $\begin{array}{l}\mathrm{CO}_{2} \\
/ \mathrm{CH}_{4}\end{array}$ \\
\hline spiroHPI-6F & 5.2 & 4.3 & 102 & 3.7 & 0.8 & 6.3 & 1.4 & 5.3 & 16 & 1.7 & 7.8 & 11.5 & 3.1 \\
\hline $\begin{array}{l}\text { spiroTR-PBO- } \\
\text { 6F }\end{array}$ & 30 & 34 & 675 & 16 & 5.9 & 29 & 1.9 & 5.7 & 23 & 1.9 & 4.9 & 12.0 & 4.1 \\
\hline PIM-1 ${ }^{c}$ & 92 & 125 & 2300 & 22 & 6.8 & 26 & 4.2 & 18 & 88 & 1.2 & 3.8 & 20.9 & 4.9 \\
\hline $\mathrm{aPBO}^{d}$ & 19 & 12 & 398 & 31 & 2.1 & 13 & 0.6 & 5.7 & 31 & 0.4 & 6.2 & 51.7 & 5.4 \\
\hline
\end{tabular}

${ }^{a}$ Diffusivity coefficient (D) is calculated from $\mathrm{P}=\mathrm{D} \cdot \mathrm{S}$.

${ }^{b}$ Solubility coefficient (S) is measured by the sorption isotherm at $35{ }^{\circ} \mathrm{C}$; more details summarized in Table $4-7$ and the sorption isotherm curves are illustrated on Figure 4-9.

${ }^{c}$ Data is referred from [9].

${ }^{\mathrm{d}}$ Data is referred from [28].

Table 4-7 Summary of gas diffusion coefficient (D) and solubility coeffecient (S) of five gases for spiroHPI-6F and spiroTR-PBO-6F at $35^{\circ} \mathrm{C}$ and $1 \mathrm{~atm}$.

\begin{tabular}{|c|c|c|c|c|c|c|c|c|c|c|}
\hline \multirow{2}{*}{ Membrane } & \multicolumn{5}{|c|}{$D\left(10^{-8} \mathrm{~cm}^{2} / \mathrm{s}\right)$} & \multicolumn{5}{|c|}{$S\left(10^{-2} \mathrm{~cm}^{3} / \mathrm{cm}^{3} \mathrm{cmHg}\right)$} \\
\hline & $\mathrm{H}_{2}$ & $\mathrm{~N}_{2}$ & $\mathrm{O}_{2}$ & $\mathrm{CH}_{4}$ & $\mathrm{CO}_{2}$ & $\mathrm{H}_{2}$ & $\mathrm{~N}_{2}$ & $\mathrm{O}_{2}$ & $\mathrm{CH}_{4}$ & $\mathrm{CO}_{2}$ \\
\hline SpiroHPI-6F & 98.75 & 3.7 & 11 & 0.8 & 6.3 & 1.6 & 1.4 & 2.0 & 5.3 & 16.3 \\
\hline SpiroTR-PBO-6F & 186.5 & 16 & 42.8 & 5.9 & 29 & 2.3 & 1.9 & 2.8 & 5.7 & 23.3 \\
\hline
\end{tabular}

\subsubsection{Gas transport properties}

Single gas permeabilities of spiroHPIs and spiroTR-PBOs were obtained for six small gas molecules ( $\mathrm{He}, \mathrm{H}_{2}, \mathrm{CO}_{2}, \mathrm{O}_{2}, \mathrm{~N}_{2}$, and $\mathrm{CH}_{4}$ ), using the time-lag method at $35^{\circ} \mathrm{C}$. Changes in gas permeability and ideal selectivity of spiroHPIs and spiroTR-PBOs are summarized in Table 48. Gas permeability of spiroTR-PBO membranes increased in the following order in terms of 
the dianhydrides in polymers: BPADA $<$ BPDA $<$ PMDA $<6$ FDA. This trend correlates with the increment of $F F V$. The most attractive result was obtained from spiroTR-PBO-6F; $\mathrm{CO}_{2}$ permeability remarkably increased from 102 to 675 Barrer and ideal $\mathrm{CO}_{2} / \mathrm{N}_{2}$ selectivity also increased from 19 to 22. This 6-fold increase of $\mathrm{CO}_{2}$ permeability of spiroTR-PBO-6F may be attributed to the free volume increase during thermal rearrangement.

When we compare the contribution to $P$ of $D$ and $S$ of spiroHPI-6F and spiroTR-PBO-6F (Table 4-6) for $\mathrm{N}_{2}, \mathrm{CO}_{2}$, and $\mathrm{CH}_{4}$, in particular, changes of $D$ were substantial whereas $S$ did not change much for all three gases. Selectivity contribution can also be divided into diffusion selectivity and solubility selectivity according to Equation (4-5). Lower $\mathrm{CO}_{2} / \mathrm{CH}_{4}$ selectivity of spiroTR-PBO-6F than spiroHPI was due to an increase in $\mathrm{CH}_{4}$ diffusion coefficient, by the expansion of the fractional free volume in the polymer presumably. Higher diffusion coefficients of spiroTR-PBO-6F than those of aPBO resulted in 1.7 times higher gas permeability; however, larger free volume elements caused by the spiro-center in spiroTRPBO-6F resulted in a loss of selectivity for the gas pairs studied. Diffusivity of spiroTR-PBO$6 \mathrm{~F}$ is similar to that of PIM-1, but gas permeability of PIM-1 is much higher due to about three times larger $S$.

Permeability of single small gases in spiroTR-PBO-6F and BP were compared with several glassy polymers (Figure 4-8). Two different patterns were found in gas permeabilities depending on $F F V$. For spiroTR-PBO-BP, having low $F F V$, the highest permeability was for $\mathrm{H}_{2}$, the sequence of permeabilities being $\mathrm{H}_{2}>\mathrm{He}>\mathrm{CO}_{2}>\mathrm{O}_{2}>\mathrm{CH}_{4}>\mathrm{N}_{2}$, as observed in polycarbonate and AF $2400(F F V=0.16)$. Because gas diffusion between the smaller free elements is significantly restricted, kinetic diameters of gas molecules are the governing factor 
in determining gas permeation of spiroTR-PBO-BP. SpiroTR-PBO-6F, however, having higher free volume, showed permeabilities in the sequence $\mathrm{CO}_{2}>\mathrm{H}_{2}>\mathrm{He}>\mathrm{O}_{2}>\mathrm{CH}_{4}>\mathrm{N}_{2}$, similar to those in PIM-1 and PTMSP. In the larger microcavities, sorption capabilities of small molecules become predominant while the effect of size selection by the diffusive pathway decreases.

Figure 4-9 shows the sorption isotherms of spiroTR-PBO-6F and spiroHPI-6F measured at $35{ }^{\circ} \mathrm{C}$ for five gases $\left(\mathrm{H}_{2}, \mathrm{O}_{2}, \mathrm{~N}_{2}, \mathrm{CO}_{2}\right.$ and $\left.\mathrm{CH}_{4}\right)$. The sorption isotherms of both polymers showed typical dual-mode sorption behavior for glassy polymers[1ㅣ]. The gas solubility is generally related with the critical temperature of gas molecules, and therefore the solubility of $\mathrm{CO}_{2}$ shows the highest value. The increase in the solubility of spiroHPI-6F before and after thermal rearrangement is about $20 \%$ for $\mathrm{CO}_{2}$. This is not as crucial as the increase in the gas permeability, but comparable with the increase in FFV. The solubility of gas, especially for $\mathrm{CO}_{2}$, is very high as compared to the solubility of gases in typical glassy polymers such as PC, PMMA and is similar to that of PTMSP $[\underline{34}, \underline{52}]$.

Figure 4-10 describes gas permeability and selectivity of the four spiroTR-PBO membranes for $\mathrm{CO}_{2} / \mathrm{CH}_{4}$ and $\mathrm{CO}_{2} / \mathrm{N}_{2}$, compared to the so-called 2008 and 1991 upper bounds. SpiroTR-PBO-6F, with the highest fractional free volume, is close to the 2008 upper bound, with permeabilities between those of aPBO and PIM-1. Note that spiroTR-PBO-6F possesses features in common with both aPBO and PIM-1, in terms of the repeating unit and preparation method. For $\mathrm{CO}_{2} / \mathrm{N}_{2}$, spiroTR-6F and PM showed higher selectivity than PIM-1 and aPBO.

Note that the high rigidity and restricted mobility of the planar backbone of spiroTR-PBOPM allows higher permeation of $\mathrm{CO}_{2}$ than that of spiroTR-PBO-BPA, which have lower 
rigidity and higher mobility due to the presence of the ether linkages. In fact, spiroTR-PBOBPA showed similar transport properties to commercial membranes such as polycarbonate and polysulfone. It is obvious that the rigidity of spiroTR-PBO-BP is a little bit lower than the TR polymer from PM, but much higher than the TR formed from BPA.

Table 4-8 Single gas permeabilities (P) and ideal selectivities $(\alpha)$ for spiroHPIs and spiroTRPBOs

\begin{tabular}{|c|c|c|c|c|c|c|c|c|c|c|c|}
\hline \multirow{2}{*}{\multicolumn{2}{|c|}{ Membrane }} & \multicolumn{6}{|c|}{$P^{a}$ (Barrer) } & \multicolumn{4}{|c|}{$\alpha^{b}$} \\
\hline & & $\mathrm{He}$ & $\mathrm{H}_{2}$ & $\mathrm{CO}_{2}$ & $\mathrm{O}_{2}$ & $\mathrm{~N}_{2}$ & $\mathrm{CH}_{4}$ & $\mathrm{H}_{2} / \mathrm{CO}_{2}$ & $\mathrm{O}_{2} / \mathrm{N}_{2}$ & $\begin{array}{l}\mathrm{CO}_{2} / \\
\mathrm{CH}_{4}\end{array}$ & $\mathrm{CO}_{2} / \mathrm{N}_{2}$ \\
\hline \multirow{4}{*}{ spiroHPI } & $6 \mathrm{~F}$ & 107 & 158 & 102 & 22 & 5.2 & 4.3 & 1.6 & 4.2 & 23 & 19 \\
\hline & PM & 152 & 235 & 240 & 40 & 10 & 14 & 1.0 & 4.2 & 17 & 25 \\
\hline & $\mathrm{BP}$ & 45 & 51 & 24 & 5.8 & 1.2 & 0.96 & 2.1 & 4.8 & 25 & 20 \\
\hline & BPA & 34 & 37 & 14 & 3.2 & 0.53 & 0.56 & 2.6 & 6.1 & 25 & 27 \\
\hline \multirow{4}{*}{$\begin{array}{c}\text { spiroTR- } \\
\text { PBO }\end{array}$} & $6 F$ & 318 & 429 & 675 & 120 & 30 & 34 & 0.6 & 3.9 & 20 & 22 \\
\hline & PM & 164 & 261 & 263 & 48 & 11 & 15 & 1.0 & 4.4 & 18 & 24 \\
\hline & BP & 112 & 143 & 87 & 20 & 5.2 & 5.7 & 1.7 & 3.9 & 15 & 17 \\
\hline & BPA & 15 & 19 & 8.8 & 2.1 & 0.45 & 0.53 & 1.9 & 4.7 & 19 & 22 \\
\hline
\end{tabular}




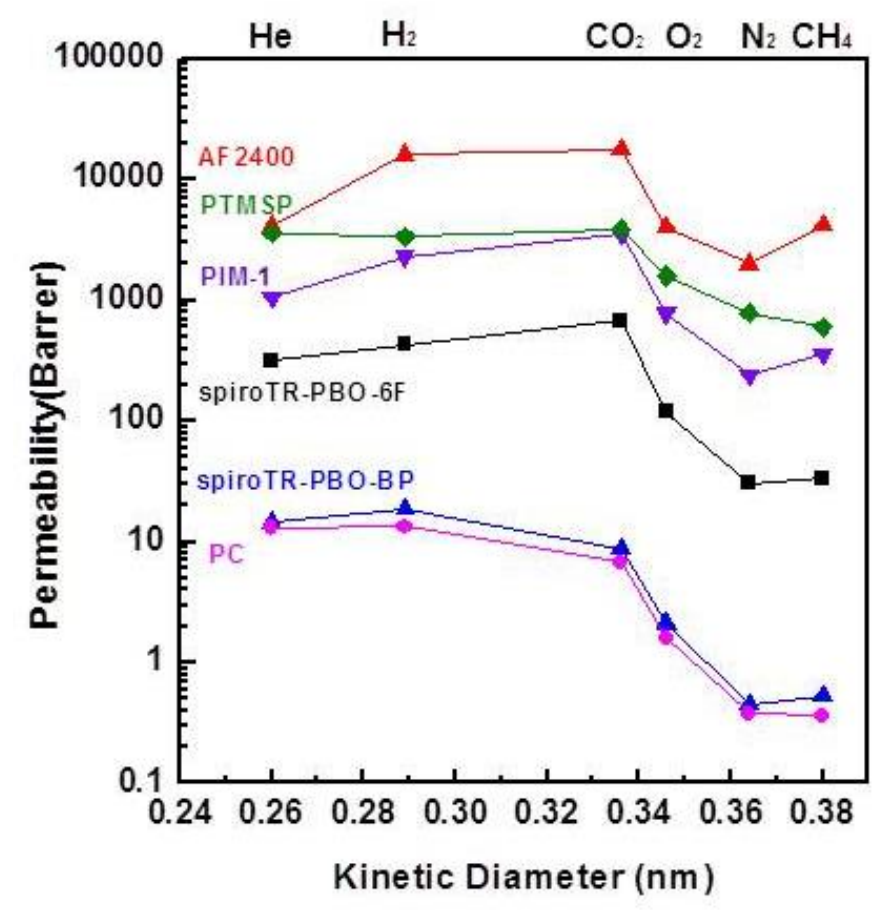

Figure 4-8 Permeability of single small gases in spiroTR-PBO-6F and spiroTR-PBO-BP with PTMSP [53], AF2400 [54], PIM-1 [53] and polycarbonate [55], as a function of the kinetic diameter of the penetrates. 

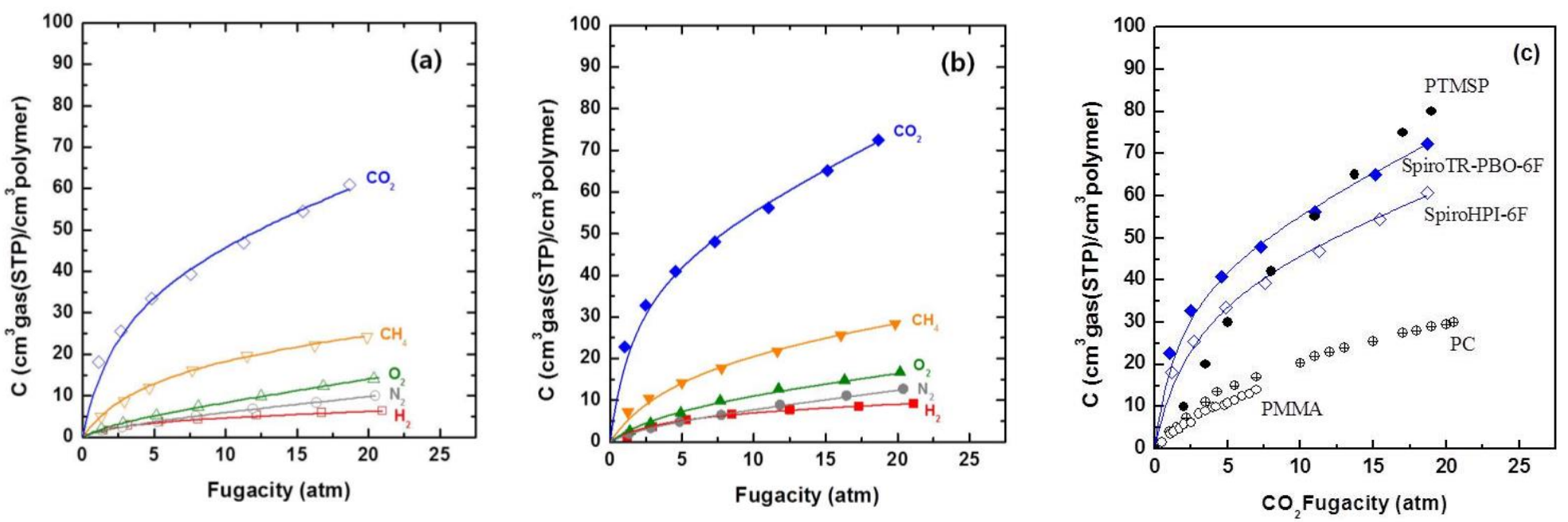

Figure 4-9 Sorption isotherm of five gases in (a) SpiroHPI-6F, (b) spiroTR-PBO-6F, and of (c) $\mathrm{CO}_{2}$ for spiroHPI-6F and spiroTRPBO-6F, PMMA, PC, and PTMSP[27, 51]. 

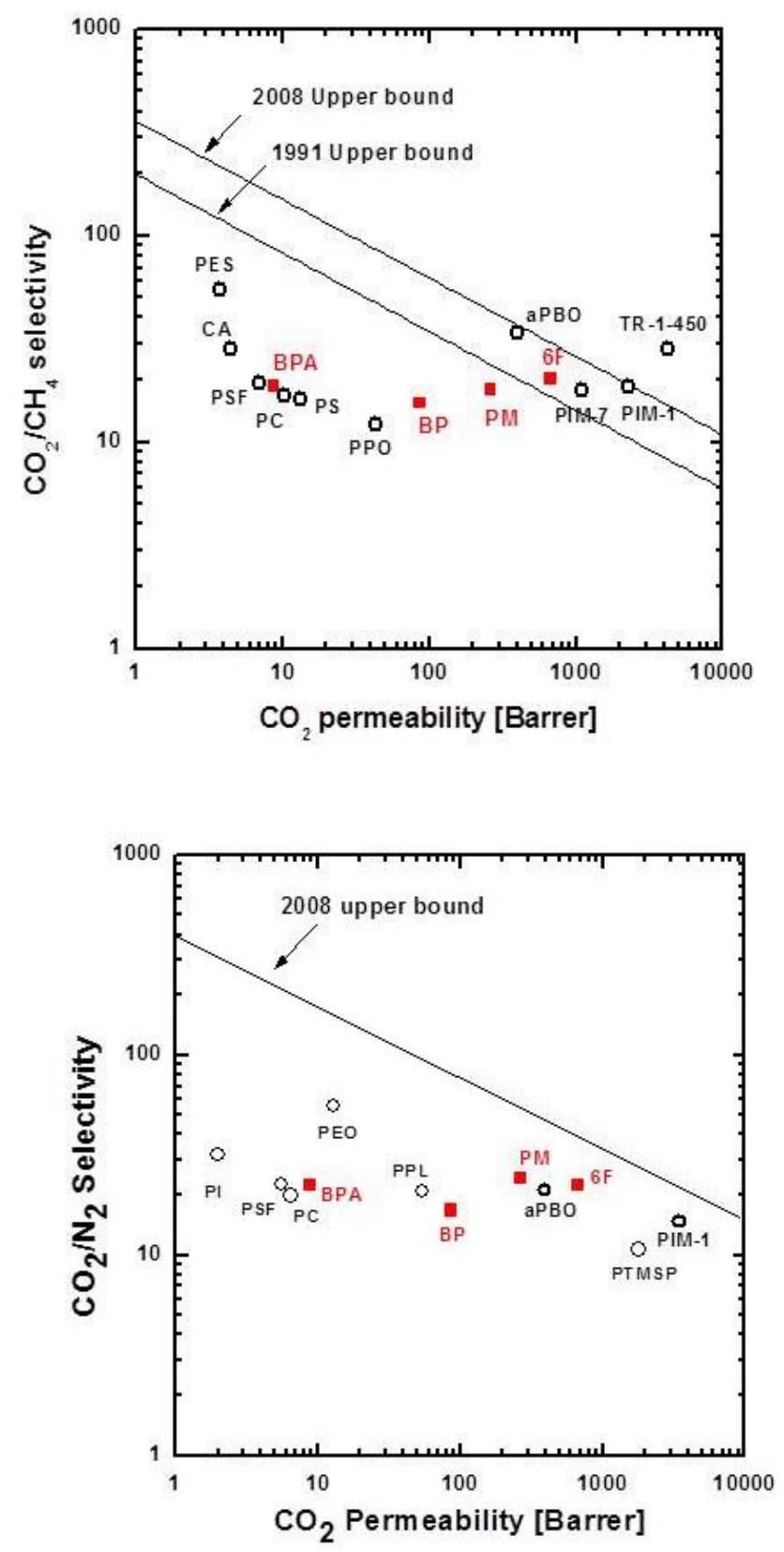

Figure 4-10 $\mathrm{CO}_{2} / \mathrm{CH}_{4}$ selectivity (top plot) and $\mathrm{CO}_{2} / \mathrm{N}_{2}$ selectivity (lower plot) against $\mathrm{CO}_{2}$ permeabilityfor spiroTR-PBO membranes (red squares) plotted with the Robeson upper bound revised in 1991[56] and 2008[57]. Data for other glassy polymers are shown for comparison. 


\subsection{Conclusions}

A spirobisindane-containing dihydroxyldiamine (3,3,3',3'- tetramethyl-1,1' - spiro bis(indan)-5,5'diamino-6,6'-diol) and various dianhydrides were used to prepare hydroxylcontaining polyimides, yielding so-called spiroHPIs. Precursor spiroHPIs were thermally treated under conditions determined by TGA isothermal analysis to obtain $100 \%$ thermallyrearranged spiroTR-PBOs. Formation of benzoxazole during thermal rearrangement was confirmed by ${ }^{13} \mathrm{C}-\mathrm{NMR}$ and ATR-FTIR, and emission of $\mathrm{CO}_{2}$ was confirmed by TGA-MS. For spiroHPIs and spiroTR-PBOs, physical properties, such as fractional free volume $(F F V), d$ spacing, and BET surface area, were highly dependent on the chemical structures of the anhydrides. For instance, the presence of a bulky side hexafluoroisopropylidene group in the polymer increased the $F F V$, while the presence of flexible ether groups in the polymer reduced the $F F V$. The spiroTR-PBOs had much better elongation at break values, even after $100 \%$ conversion, than TR-PBOs which do not contain spirobisindane moieties. We attributed this to the enhanced entanglement by spiro-center molecular angle, with around $90^{\circ}$ angle hinges, compared with rigid $110^{\circ}$ angle hexafluoroisopropylidene.

After thermal rearrangement, spiroTR-PBO showed increased gas permeability up to 675 Barrer and high elongation at break around 20\%.We demonstrated that mechanically robust spiroTR-PBO gas separation membranes could be fabricated with high gas separation performance, in particular for carbon capture and sequestration.

\section{References}

[1] T. Graham, On the absorption and dialytic separation of gases by colloid septa, Phil. Trans. 
R. Soc. Lond., 156 (1866) 399-439.

[2] H. Stadler, F. Beggel, M. Habermehl, B. Persigehl, R. Kneer, M. Modigell, P. Jeschke, Oxyfuel coal combustion by efficient integration of oxygen transport membranes, Int. J. Greenh. Gas Con., 5 (2011) 7-15.

[3] J.P. Ciferno, T.E. Fout, A.P. Jones, J.T. Murphy, Capturing carbon from existing coal-fired power plants, Chem. Eng. Prog., 105 (2009) 33-41.

[4] T.C. Merkel, H.Q. Lin, X.T. Wei, R. Baker, Power plant post-combustion carbon dioxide capture: An opportunity for membranes, J. Membr. Sci., 359 (2010) 126-139.

[5] C.E. Powell, G.G. Qiao, Polymeric $\mathrm{CO}_{2} / \mathrm{N}_{2}$ gas separation membranes for the capture of carbon dioxide from power plant flue gases, J. Membr. Sci., 279 (2006) 1-49.

[6] H.B. Park, C.H. Jung, Y.M. Lee, A.J. Hill, S.J. Pas, S.T. Mudie, E. Van Wagner, B.D. Freeman, D.J. Cookson, Polymers with cavities tuned for fast selective transport of small molecules and ions, Science, 318 (2007) 254-258.

[7] J. E.B., L. Sonja, J.C. Christopher, S.H. Evan, D.N. Ricahrd, L.G. Douglas, Synthesis and performance of polymerizable room-temperature ionic liguids as gas separation membranes, Ind. Eng. Che. Res., 46 (2007) 5397-5404

[8] J. de Abajo, J.G. de la Campa, A.E. Lozano, J. Espeso, C. Garcia, Designing aromatic polyamides and polyimides for gas separation membranes, Macromol. Symp., 199 (2003) 293305.

[9] P.M. Budd, K.J. Msayib, C.E. Tattershall, B.S. Ghanem, K.J. Reynolds, N.B. McKeown, D. 
Fritsch, Gas separation membranes from polymers of intrinsic microporosity, J. Membr. Sci., 251 (2005) 263-269.

[10] M. Calle, A.E. Lozano, J. de Abajo, J.G. de la Campa, C. Alvarez, Design of gas separation membranes derived of rigid aromatic polyimides. 1. Polymers from diamines containing ditert-butyl side groups, J. Membr. Sci., 365 (2010) 145-153.

[11] A. Ghosh, S.K. Sen, S. Banerjee, B. Voit, Solubility improvements in aromatic polyimides by macromolecular engineering, Rsc Adv, 2 (2012) 5900-5926.

[12] D.J. Liaw, K.L. Wang, Y.C. Huang, K.R. Lee, J.Y. Lai, C.S. Ha, Advanced polyimide materials: Syntheses, physical properties and applications, Prog. Polym. Sci., 37 (2012) 907974.

[13] C.H. Chou, D.S. Reddy, C.F. Shu, Synthesis and characterization of spirobifluorene-based polyimides, J. Polym. Sci., Part A: Polym. Chem., 40 (2002) 3615-3621.

[14] Y.H. Kim, H.S. Kim, S.K. Kwon, Synthesis and characterization of highly soluble and oxygen permeable new polyimides based on twisted biphenyl dianhydride and spirobifluorene diamine, Macromolecules, 38 (2005) 7950-7956.

[15] D.S. Reddy, C.H. Chou, C.F. Shu, G.H. Lee, Synthesis and characterization of soluble poly(ether imide)s based on 2,2'-bis(4-aminophenoxy)-9,9'-spirobifluorene, Polymer, 44 (2003) 557-563.

[16] S.H. Hsiao, C.Y. Yang, Synthesis and evaluation of novel polyimides derived from spirobichrom an diether anhydride, J. Polym. Sci., Part A: Polym. Chem., 36 (1998) 215-215. 
[17] D.S. Reddy, C.F. Shu, F.I. Wu, Synthesis and characterization of soluble polyimides derived from 2,2'-bis(3,4-dicarboxyphenoxy)-9,9'-spirobifluorene dianhydride, J. Polym. Sci., Part A: Polym. Chem., 40 (2002) 262-268.

[18] F.S. Han, M.X. Ding, L.X. Gao, Polyimides from 3,3'-dioxo-1,1'-spirodiphthalan-5,5',6,6'tetracarboxylic dianhydride, Polymer, 40 (1999) 3809-3813.

[19] P.M. Budd, E.S. Elabas, B.S. Ghanem, S. Makhseed, N.B. McKeown, K.J. Msayib, C.E. Tattershall, D. Wang, Solution-processed, organophilic membrane derived from a polymer of intrinsic microporosity, Adv. Mater., 16 (2004) 456-459.

[20] N.B. McKeown, B. Gahnem, K.J. Msayib, P.M. Budd, C.E. Tattershall, K. Mahmood, S. Tan, D. Book, H.W. Langmi, A. Walton, Towards polymer-based hydrogen storage materials: Engineering ultramicroporous cavities within polymers of intrinsic microporosity, Angew. Chem. Int. Ed., 45 (2006) 1804-1807.

[21] B.S. Ghanem, K.J. Msayib, N.B. McKeown, K.D.M. Harris, Z. Pan, P.M. Budd, A. Butler, J. Selbie, D. Book, A. Walton, A triptycene-based polymer of intrinsic microposity that displays enhanced surface area and hydrogen adsorption, Chem. Commun., (2007) 67-69.

[22] X.H. Ma, R. Swaidan, Y. Belmabkhout, Y.H. Zhu, E. Litwiller, M. Jouiad, I. Pinnau, Y. Han, Synthesis and gas transport properties of hydroxyl-functionalized polyimides with intrinsic microporosity, Macromolecules, 45 (2012) 3841-3849.

[23] A.M. Foley, B.P.O. Gallachoir, J. Hur, R. Baldick, E.J. McKeogh, A strategic review of electricity systems models, Energy, 35 (2010) 4522-4530.

[24] C.H. Jung, J.E. Lee, S.H. Han, H.B. Park, Y.M. Lee, Highly permeable and selective 148 
poly(benzoxazole-co-imide) membranes for gas separation, J. Membr. Sci., 350 (2010) 301309.

[25] H.B. Park, S.H. Han, C.H. Jung, Y.M. Lee, A.J. Hill, Thermally rearranged (TR) polymer membranes for $\mathrm{CO}_{2}$ separation, J. Membr. Sci., 359 (2010) 11-24.

[26] M. Calle, Y.M. Lee, Thermally rearranged (TR) poly(ether-benzoxazole) membranes for gas separation, Macromolecules, 44 (2011) 1156-1165.

[27] S.H. Han, H.J. Kwon, K.Y. Kim, J.G. Seong, C.H. Park, S. Kim, C.M. Doherty, A.W. Thornton, A.J. Hill, A.E. Lozano, K.A. Berchtoldf, Y.M. Lee, Tuning microcavities in thermally rearranged polymer membranes for $\mathrm{CO}_{2}$ capture, Phys. Chem. Chem. Phys., 14 (2012) 4365-4373.

[28] S.H. Han, N. Misdan, S. Kim, C.M. Doherty, A.J. Hill, Y.M. Lee, Thermally rearranged (TR) polybenzoxazole: Effects of diverse imidization routes on physical properties and gas transport behaviors, Macromolecules, 43 (2010) 7657-7667.

[29] A.M. Kratochvil, W.J. Koros, Decarboxylation induced cross-linking of a polyimide for enhanced $\mathrm{CO}_{2}$ plasticization resistance, Macromolecules, 41 (2008) 7920-7927.

[30] F.Y. Li, Y.C. Xiao, T.S. Chung, S. Kawi, High-Performance thermally self cross-linked polymer of intrinsic microporosity (PIM-1) membranes for energy development, Macromolecules, 45 (2012) 1427-1437.

[31] Y.C. Xiao, T.S. Chung, Grafting thermally labile molecules on cross-linkable polyimide to design membrane materials for natural gas purification and $\mathrm{CO}_{2}$ capture, Energy Environ. Sci., 4 (2011) 201-208. 
[32] T. Omote, K. Koseki, T. Yamaoka, Fluorine-containing photoreactive polyimides .6. Synthesis and properties of a novel photoreactive polyimide based on photoinduced acidolysis and the kinetics for its acidolysis, Macromolecules, 23 (1990) 4788-4795.

[33] T. Omote, H. Mochizuki, K. Koseki, T. Yamaoka, Fluorine-containing photoreactive polyimides .7. Photochemical reaction of pendant 1,2-naphthoquinone diazide moieties in novel photoreactive polyimides, Macromolecules, 23 (1990) 4796-4802.

[34] E.S. Sanders, W.J. Koros, H.B. Hopfenberg, V.T. Stannett, Mixed gas sorption in glassy polymers: Equipment design considerations and preliminary results, J. Membr. Sci., 13 (1983) $161-174$.

[35] G.L. Tullos, J.M. Powers, S.J. Jeskey, L.J. Mathias, Thermal conversion of hydroxycontaining imides to benzoxazoles: Polymer and model compound study, Macromolecules, 32 (1999) 3598-3612.

[36] G.L. Tullos, L.J. Mathias, Unexpected thermal conversion of hydroxy-containing polyimides to polybenzoxazoles, Polymer, 40 (1999) 3463-3468.

[37] J.H. Chang, K.M. Park, S.M. Lee, J.B. Oh, Two-step thermal conversion from poly(amic acid) to polybenzoxazole via polyimide: Their thermal and mechanical properties, J. Polym. Sci., Part B: Polym. Phys., 38 (2000) 2537-2545.

[38] Y.Y. Jiang, F.T. Willmore, D. Sanders, Z.P. Smith, C.P. Ribeiro, C.M. Doherty, A. Thornton, A.J. Hill, B.D. Freeman, I.C. Sanchez, Cavity size, sorption and transport characteristics of thermally rearranged (TR) polymers, Polymer, 52 (2011) 2244-2254.

[39] P.M. Budd, B.S. Ghanem, S. Makhseed, N.B. McKeown, K.J. Msayib, C.E. Tattershall, 
Polymers of intrinsic microporosity (PIMs): robust, solution-processable, organic nanoporous materials, Chem. Commun., (2004) 230-231.

[40] B.S. Ghanem, N.B. McKeown, P.M. Budd, D. Fritsch, Polymers of intrinsic microporosity derived from bis(phenazyl) monomers, Macromolecules, 41 (2008) 1640-1646.

[41] K.S.W. Sing, The use of gas-adsorption for the characterization of porous solids, Colloid. Surface., 38 (1989) 113-124.

[42] J. Song, N. Du, Y. Dai, G.P. Robertson, M.D. Guiver, S. Thomas, I. Pinnau, Linear high molecular weight ladder polymers by optimized polycondensation of tetrahydroxytetramethyl-spirobisindane and 1,4-dicyanotetrafluorobenzene, Macromolecules, 41 (2008) 7411-7417.

[43] B.D. Freeman, Y.P. Yampolskii, Addition-type polynorbornene with $\mathrm{Si}\left(\mathrm{CH}_{3}\right)_{3}$ side groups: detailed study of gas permeation, free volume and thermodynamic properties, in: Y.P. Yampolskii, L. Starannikova, N. Belov, M. Gringolts, E. Finkelshtein, V. Shantarovich (Eds.) Membrane Gas Separation, John Wiley \& Sons, 2011, pp. 43-57.

[44] V.P. Shantarovich, I.B. Kevdina, Y.P. Yampolskii, A.Y. Alentiev, Positron annihilation lifetime study of high and low free volume glassy polymers: Effects of free volume sizes on the permeability and permselectivity, Macromolecules, 33 (2000) 7453-7466.

[45] M. Heuchel, D. Fritsch, P.M. Budd, N.B. McKeown, D. Hofmann, Atomistic packing model and free volume distribution of a polymer with intrinsic microporosity (PIM-1), J. Membr. Sci., 318 (2008) 84-99.

[46] S.K. Sen, S. Banerjee, Spiro-biindane containing fluorinated poly(ether imide)s: Synthesis, 
characterization and gas separation properties, J. Membr. Sci., 365 (2010) 329-340.

[47] Z.M. Qiu, S.B. Zhang, W.M. Li, Synthesis and gas permeability of novel fluorinated poly(phenylene-co-naphthalimide)s, J. Appl. Polym. Sci., 104 (2007) 2395-2402.

[48] Z.M. Qiu, G. Chen, Q.Y. Zhang, S.B. Zhang, Synthesis and gas transport property of polyimide from 2,2'-disubstituted biphenyltetracarboxylic dianhydrides (BPDA), Eur. Polym. J., 43 (2007) 194-204.

[49] C.Y. Yang, S.L.C. Hsu, J.S. Chen, Synthesis and properties of 6FDA-BisAAF-PPD copolyimides for microelectronic applications, J. Appl. Polym. Sci., 98 (2005) 2064-2069.

[50] S. Banerjee, M.K. Madhra, A.K. Salunke, G. Maier, Synthesis and properties of fluorinated polyimides. 1. Derived from novel 4,4'-bis(aminophenoxy)-3,3'-trifluoromethyl terphenyl, J. Polym. Sci., Part A: Polym. Chem., 40 (2002) 1016-1027.

[51] Y. Tsujita, Gas sorption and permeation of glassy polymers with microvoids, Prog. Polym. Sci., 28 (2003) 1377-1401.

[52] T.C. Merkel, V. Bondar, K. Nagai, B.D. Freeman, Sorption and transport of hydrocarbon and perfluorocarbon gases in poly(1-trimethylsilyl-1-propyne), J. Polym. Sci., Part B: Polym. Phys., 38 (2000) 273-296.

[53] C.L. Staiger, S.J. Pas, A.J. Hill, C.J. Cornelius, Gas separation, free volume distribution, and physical aging of a highly microporous spirobisindane polymer, Chem. Mater., 20 (2008) 2606-2608.

[54] I. Pinnau, L.G. Toy, Transport of organic vapors through poly(1-trimethylsilyl-1-propyne), 
J. Membr. Sci., 116 (1996) 199-209.

[55] M.W. Hellums, W.J. Koros, G.R. Husk, D.R. Paul, Fluorinated polycarbonates for gas separation applications, J. Membr. Sci., 46 (1989) 93-112.

[56] L.M. Robeson, Correlation of separation factor versus permeability for polymeric membranes, J. Membr. Sci., 62 (1991) 165-185.

[57] L.M. Robeson, The upper bound revisited, J. Membr. Sci., 320 (2008) 390-400. 


\section{$\underline{\text { Chapter } 5}$}

Cross-linking Effect on the Microstructure and Gas Transport Properties of Thermally Rearranged

Poly(benzoxazole-co-imide)s 


\subsection{Introduction}

Gas separation using polymer membranes has received more attention than inorganic membranes like ceramic, metal or porous glass membranes due to polymeric membranes' high surface to volume ratio and excellent processability.[1-3] Moreover, polymeric membranes possess unique advantages in that their structures are easily functionalizable and morphological modifications enable the fine-tuning of membrane properties for many gas separation applications.[4, 5] Among a large number of polymer materials, thermally rearranged (TR) polymers have received considerable attentions for their unprecedented gas permeation properties that are mainly attributed to their rigid polymer chain structure as well as their microporous bimodal cavities. The gas transport properties of TR polymer membranes can be easily manipulated by controlling the percentage of TR conversion $(\% C)$ via tuning of their chemical structures and thermal treatment conditions.[6-14]

Apart from studies on polymer materials for permeation property improvement, another focus of membrane development has been on enhancing their sustained performance against undesirable plasticization phenomena, as well as improving their chemical and thermal stability. One major strategy to achieve this goal is polymer cross-linking.[15-17] In this vein of thought, cross-linking of copolyimides with DABA has been extensively studied by modifying carboxylic acid groups in DABA through (i) ionic cross-linking with aluminum ions,[18] (ii) covalent cross-linking using diols or short-chain poly(ethylene glycol),[19-21] and (iii) decarboxylation induced cross-linking by thermal treatment below the glass transition temperature $\left(\mathrm{T}_{\mathrm{g}}\right)_{\text {. [22] }}$ Furthermore, decarboxylation induced cross-linking has been applied on the industrially-preferred hollow fiber geometry.[23] 
Recently, several cross-linking approaches were also explored on TR polymers by incorporating 1,3-diamino benzoic acid (DABA) to prepare cross-linked thermally rearranged poly(benzoxazole-co-imide) (XTR-PBOI) to further promote gas permeation properties.[24, 25] It was found that such a cross-linking approach substantially improved the gas permeability by producing larger cavities than those found in TR-PBO. The larger size was mainly attributed to a synergetic effect of thermal rearrangement and crosslinking, through either covalent crosslinking with 1,4-butandiol or the thermal radical cross-linking between pendent groups of DABA in the 6FDA-APAF-DABA copolymer. [24, 25] These studies offered rationales explaining the high permeability of TR-PBO prepared from thermal imidization (tPBO) compared to ones prepared from azeotropic imidization (aPBO).[12] Despite the excellent permeation properties achieved through cross-linking, these previous studies only focused on final permeation performance, when the membrane was completely cross-linked and thermally rearranged. Therefore, the role of cross-linking on thermal rearrangement, as well as on the morphological and permeation properties of the membrane, was not fully explored.

Here, a comprehensive study was performed using a hydroxyl copolyimide based on 6FDA-HAB-DABA to prepare cross-linked TR membranes. The effect of thermal treatment temperature on cross-linking and thermal rearrangement was carefully examined by characterizing a series of membranes which prepared at different thermal treatment temperatures, so that the role of cross-linking on thermal rearrangement could be revealed. In addition, an uncross-linkable hydroxyl copolyimide, based on 6FDA-HAB-mPD, was also prepared and used to cast TR membranes without cross-linking, following the same thermal treatment protocol. The results from these uncross-linked TR membranes were compared 
against TR membranes that had been cross-linked to provide an in-depth understanding of the synergetic effects of cross-linking and thermal rearrangement on membrane properties.

\subsection{Experimental}

\subsubsection{Materials}

4,4'-(hexafluoroisopropylidene) diphthalic anhydride (6FDA) was purchased from Daikin Industries, Ltd. (Osaka, Japan) and 3,3'-dihydroxyl-4,4'-diamino-biphenyl (HAB) was acquired from Wakayama Seika Kogyo Co., Ltd. (Wakayama, Japan). 3,5-diaminobenzoic acid (DABA) and m-phenylenediamine (mPD) were purchased from Sigma-Aldrich Co. LLC (St. Louis, MO, USA) and were sublimated before use. N-methyl-2- pyrrolidone (NMP) and $o$ xylene were also purchased from Sigma-Aldrich and used without further purification.

\subsubsection{Synthesis of Hydroxyl Copolyimides.}

A mixture of HAB (12 mmol) and DABA (8 mmol) and a mixture of HAB (12 mmol) and mPD (8 mmol) were introduced into two completely dry $250 \mathrm{~mL}$ four-neck round-bottomed flasks then washed with 35mL of NMP. After the monomers had completely dissolved at room temperature and cooled in an ice bath, 6FDA (20 mmol) was introduced into each flask. The crude, yellow solutions were stirred for $12 \mathrm{~h}$. Imidization was conducted at $180^{\circ} \mathrm{C}$ for $12 \mathrm{~h}$ by $o$-xylene reflux in a Dean-Stack trap equipped flask, purged with nitrogen. Two dark yellow solutions were precipitated in a methanol/water (1:3) mixture and washed with de-ionized 
water three times to remove the NMP and $o$-xylene. The precipitates were then filtered and dried in a vacuum oven at $150^{\circ} \mathrm{C}$ for more than $24 \mathrm{~h}$. The DABA incorporated polymer was labeled HPI-DB and the mPD incorporated polymer was labeled HPI-mPD. The spectroscopic data for HPI-DB is as follows: ${ }^{1} \mathrm{H}$ NMR (300 MHz, DMSO- $d_{6}$, ppm): 13.48 (m, $-\mathrm{COOH}$ ), 10.09 (s, $-\mathrm{OH}), 8.18$ (m, $\left.\mathrm{H}_{\mathrm{ar}}\right), 8.00$ (s, $\left.\mathrm{H}_{\mathrm{ar}}\right), 7.81$ (m, $\left.\mathrm{H}_{\mathrm{ar}}\right), 7.40$ (d, $\left.\mathrm{H}_{\mathrm{ar}}, J=7.33 \mathrm{~Hz}\right), 7.21$ (s, $\mathrm{H}_{\mathrm{ar}}$. FT-IR (film): $v(\mathrm{O}-\mathrm{H})$ at $3377 \mathrm{~cm}^{-1}, v(\mathrm{C}=\mathrm{O})$ at 1782 and $1715 \mathrm{~cm}^{-1}$, Ar $(\mathrm{C}-\mathrm{C})$ at 1609 , $1498 \mathrm{~cm}^{-1}$, imide $v(\mathrm{C}-\mathrm{N})$ at $1366 \mathrm{~cm}^{-1},(\mathrm{C}-\mathrm{F})$ at $1297-1142$, imide $(\mathrm{C}-\mathrm{N}-\mathrm{C})$ at $1097 \mathrm{~cm}^{-1} \cdot \eta_{\text {int: }}$ : $0.68 \mathrm{dL} \mathrm{g}^{-1}$, Mw: 142,000 $\mathrm{gol}^{-1}$, PDI: 1.9. The spectroscopic data for HPI-mPD is given as follows: ${ }^{1} \mathrm{H}$ NMR (300 MHz, DMSO- $\left.d_{6}, \mathrm{ppm}\right): 10.12$ (s, $-\mathrm{OH}$ ), 8.21 (d, $\mathrm{H}_{\mathrm{ar}}, J=6.16 \mathrm{~Hz}$ ), 8.16 (m, $\left.\mathrm{H}_{\mathrm{ar}}\right), 7.99$ (d, $\left.\mathrm{H}_{\mathrm{ar}}, J=9.98 \mathrm{~Hz}\right), 7.83\left(\mathrm{~m}, \mathrm{H}_{\mathrm{ar}}\right), 7.39$ (d, $\left.\mathrm{H}_{\mathrm{ar}}, J=2.93 \mathrm{~Hz}\right), 7.21\left(\mathrm{~s}, \mathrm{H}_{\mathrm{ar}}\right) . \mathrm{FT}-$ IR (film): $v(\mathrm{O}-\mathrm{H})$ at $3418 \mathrm{~cm}^{-1}, v(\mathrm{C}=\mathrm{O})$ at 1784 and $1714 \mathrm{~cm}^{-1}, \mathrm{Ar}(\mathrm{C}-\mathrm{C})$ at $1619,1519 \mathrm{~cm}^{-1}$, imide $v(\mathrm{C}-\mathrm{N})$ at $1377 \mathrm{~cm}^{-1},(\mathrm{C}-\mathrm{F})$ at $1299-1135$, imide $(\mathrm{C}-\mathrm{N}-\mathrm{C})$ at 1102 and $720 \mathrm{~cm}^{-1} \cdot \eta_{\text {int: }}$ : $0.82 \mathrm{dL} \mathrm{g}^{-1}$, Mw: 197,000g mol ${ }^{-1}$, PDI: 1.9.

\subsubsection{Preparation of Hydroxyl Copolyimide Membranes.}

HPI-DB and HPI-mPD polymers (20\%, w/v) were dissolved in NMP and then filtered using a $3 \mu \mathrm{m}$ GMF syringe filter. The degassed polymer solution was poured onto a clean glass plate, cast using a doctor-blade, and then slowly heated to $250^{\circ} \mathrm{C}$ under vacuum. When finished, $50 \mu \mathrm{m}$ thick HPI-DB and HPI-mPD membranes were obtained.

\subsubsection{Preparation of Cross-linked Hydroxyl Copolyimides and Thermally Rearranged}




\section{Poly (benzoxazole-co-imide) Membranes.}

To remove any residual solvent, the HPI-DB membranes were heated to $250^{\circ} \mathrm{C}$ while the HPI-mPD samples were heated to $300^{\circ} \mathrm{C}$ for $1 \mathrm{~h}$ each in a muffle furnace purged with high purity argon. For thermal cross-linking of the HPI-DB membranes, the membranes were heated to $300^{\circ} \mathrm{C}$ for $3 \mathrm{~h}$. Thermal rearrangement was conducted by heating the membranes to either 350,400 , or $425^{\circ} \mathrm{C}$ for $1 \mathrm{~h}$ or $450^{\circ} \mathrm{C}$ for 30 mins.

\subsubsection{Characterization.}

${ }^{1} \mathrm{H}$ spectra and molecular weights of HPI-DB and HPI-mPD were measured using Nuclear Magnetic Resonance (NMR, Mercury Plus 300MHz, Varian, Inc., Palo Alto, CA, USA) and gel-permeation chromatography (GPC, TosohHLC-8320GPC, Seoul, Korea) with a TSKTM Super Multi pore HZ-M column and a refractive index (RI) detector in THF with standard polystyrene as the basis for measurement. The glass transition temperature $\left(\mathrm{T}_{\mathrm{g}}\right)$ and thermal relaxation behavior of the polymers were determined using a dynamic mechanical analyzer (DMAQ800, TA Instruments, New Castle, DE, USA) in tension mode. Cross-linking and the formation benzoxazole by thermal rearrangement were confirmed using a Thermo-Gravimetric Analyzer (TGAQ500, TA Instruments) coupled with mass spectrometry (MS, ThermoStar GSD 301T, Pfeiffer Vacuum GmbH, Asslar, Germany) and Fourier-transformation infrared spectroscopy (FT-IR, Nicolet6700, Thermo Fisher Scientific Inc., MA, USA). The gel content of the copolyimide was also investigated to evaluate the degree of cross-linking in the sub- $\mathrm{T}_{\mathrm{g}}$ condition by measuring the residual weight after dissolving the dense films in NMP and heating 
up to $150^{\circ} \mathrm{C}$, following the protocols developed in a previous study.[26] Changes in polymer chain distances were analyzed in solid films using wide-angle X-ray diffractometry (WAXD) (Rigaku Denki D/MAX-2500, Rigaku, Japan) with $\mathrm{CuK}_{\alpha}$ (wavelength $\lambda=1.54 \AA$ ) radiation. The average $d$-spacing was calculated by Bragg's equation, as follows:

$$
n \lambda=2 d \sin \theta
$$

Pure gas permeability of six gases $\left(\mathrm{He}, \mathrm{H}_{2}, \mathrm{O}_{2}, \mathrm{~N}_{2}, \mathrm{CO}_{2}\right.$, and $\left.\mathrm{CH}_{4}\right)$ and the ideal selectivity of each pair were measured using the time-lag method at $35^{\circ} \mathrm{C}$ with a constant downstream volume. The equations below were used to calculate the gas permeability (5-2) and ideal selectivity (5-3).

$$
\begin{gathered}
\mathrm{P}=\left(\frac{V(S T P) \cdot l}{\Delta p \cdot A \cdot T}\right) \frac{d p}{d t} \\
\alpha=\frac{\mathrm{P}_{1}}{\mathrm{P}_{2}}
\end{gathered}
$$

where $\mathrm{P}(\mathrm{cmHg})$ is the gas permeability, $\mathrm{V}\left(\mathrm{cm}^{3}\right)$ is the volume rate, $l(\mathrm{~cm})$ is the membrane thickness, $\mathrm{A}\left(\mathrm{cm}^{2}\right)$ is the effective area of the membrane, and $\mathrm{T}(\mathrm{K})$ is the temperature. The unit of permeability is Barrer and it is based on standard temperature and pressure (STP) conditions (1 Barrer $\left.=10^{-10} \mathrm{~cm}^{3}(\mathrm{STP}) \cdot \mathrm{cm} / \mathrm{cm}^{2} \cdot \mathrm{s} \cdot \mathrm{cmHg}\right) \cdot \alpha$ denotes the ideal selectivity, which is the ratio of pure gas permeability of gas 1 over gas 2 .

Gas permeability (P) is presented using two terms, in accordance with the solutiondiffusion model, with the diffusivity coefficient (D) as the kinetic term describing the mobility of gas molecules passing through the membrane and the solubility coefficient (S) as the 
thermodynamic term describing the amount of the gas molecules sorbed into the membrane as shown below.

$$
\mathrm{P}=\mathrm{D} \times \mathrm{S}
$$

In order to determine the solubility coefficient (S) more accurately, the barometric pressure decay method with a dual-volume, dual-transducer apparatus was used under constant pressure and temperature.[27, 28] The detailed experimental protocol can be found in our previous publication.[29] The dual-sorption parameters including $C_{D}\left(\mathrm{~cm}^{3}(\mathrm{STP}) \cdot \mathrm{cm}^{-3}\right)$ and $C_{H}\left(\mathrm{~cm}^{3}\right.$ $(\mathrm{STP}) \cdot \mathrm{cm}^{-3}$ ) were calculated based on the following equations,

$$
\begin{gathered}
\mathrm{S}=\frac{C}{p} \\
\mathrm{C}=C_{D}+C_{H}=k_{D} p+\frac{C_{H}^{\prime} b f}{1+b f}
\end{gathered}
$$

where $k_{D}\left(\mathrm{~cm}^{3}\right.$ STP $\cdot \mathrm{cm}^{-3}$ polymer $\left.\cdot \mathrm{atm}^{-1}\right)$ is Henry's law coefficient, which is related to the equilibrium matrix of the glassy polymer, $f(\mathrm{~atm})$ is the gas fugacity, $C^{\prime}{ }_{H}\left(\mathrm{~cm}^{3}{ }_{\mathrm{STP}} \cdot \mathrm{cm}^{-3}\right.$ polymer $)$ is the Langmuir sorption capacity, which is related to the non-equilibrium excess free volume, and $b\left(\mathrm{~atm}^{-1}\right)$ is the Langmuir affinity constant.[30, 31]

Mixed-gas permeation tests were carried out using a $\mathrm{CO}_{2} / \mathrm{CH}_{4}$ (1:1 volume ratio.) gas mixture. The permeate gas composition was determined by a 490 Micro gas chromatography (GC) instrument (Agilent Technologies, Inc. Santa Clara, CA, USA) equipped with a thermal conductivity detector. The stage-cut was kept below 0.01 using argon sweep gas controlled by a mass flow controller (Line Tech M3030VA) with a $10 \mathrm{~cm}^{3}$ (STP) $\mathrm{min}^{-1}$ full scale. The total 
feed pressure was manipulated by a backpressure regulator (Tescom 44-1700) to be in the range of 5 to 40 bar and the membranes were exposed to each pressure for more than $3 \mathrm{~h}$ until stabilized. The permeate side was maintained at atmospheric pressure. The permeability ( $\left.\mathrm{P}^{*}\right)$ of each species and the selectivity $\left(\alpha^{*}\right)$ in terms of fugacity were defined as follows.

$$
\begin{gathered}
\mathrm{P}_{1}^{*}=\frac{N_{1} l}{f_{\mathrm{f} 1}-f_{\mathrm{p} 1}} \\
\alpha^{*}=\frac{\mathrm{P}_{1}^{*}}{\mathrm{P}_{2}^{*}}=\frac{y_{1} / y_{2}}{f_{\mathrm{p} 1} / f_{\mathrm{p} 2}}
\end{gathered}
$$

where $N_{1}$ is the steady-state flux of gas species $1, l$ is the thickness of the dense film, and $f$ f1 and $f_{\mathrm{p} 1}$ are the fugacity of gas species 1 in the feed and permeate sides, respectively. These were calculated using the virial equation of state with the second virial coefficient. $y_{1}$ and $y_{2}$ are the permeate-side mole fractions of gas species 1 and 2, respectively, as measured by GC.

\subsection{Results and Discussions}

\subsubsection{Preparation and Characterization of Hydroxyl Copolyimides (HPI) and Sub- $\mathbf{T}_{\mathrm{g}}$ Cross-linked Hydroxyl Copolyimides (XHPI).}

A cross-linkable 6FDA-based hydroxyl copolyimide (HPI-DB) comprised of HAB (TRable diamine) and DABA (non-TR-able diamine with a cross-linkable carboxylic acid group) in a 3:2 molar ratio was synthesized. As a comparison, an uncross-linkable hydroxyl copolyimide, incorporating mPD instead of DABA, was also synthesized (HPI-mPD). The chemical structures, as well as the ${ }^{1} \mathrm{H}$ spectra results of the two HPIs, are shown in Figure 5-1. 
The dense films, cast from these two HPIs, were a clear yellowish color, primarily due to the high molecular weight of the membranes $\left(100,000 \mathrm{~g} \mathrm{~mol}^{-1}\right)$.
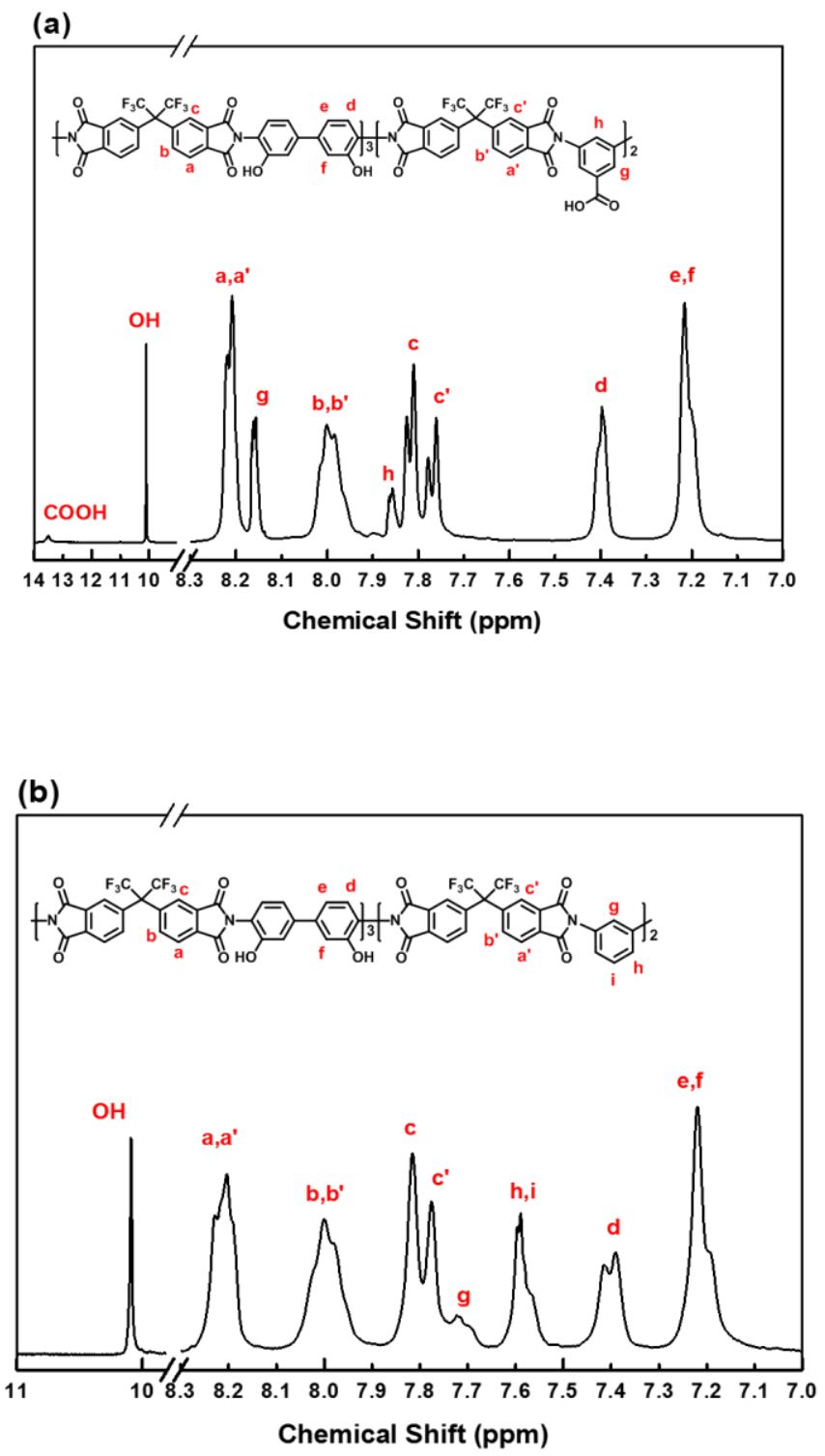

Figure 5-1 Chemical structures and 1H spectra of (a) HPI-DB and (b) HPI-mPD. 
Thermal properties of HPI-DB and HPI-mPD were characterized using DMA and TGA to identify their $\mathrm{T}_{\mathrm{g}}$. DMA measures the modulus variations of aromatic glassy polymers with increasing temperature, thereby providing critical information on the glass-rubber transition behavior of the main-chain ( $\alpha$ relaxation) and side-chain motion ( $\beta$ relaxation) by detecting susceptible movements with given oscillations.[32, 33] As shown in Figure 5-2(a), the changes in storage modulus and Tan $\delta$ of HPI-DB and HPI-mPD were measured as a function of temperature up to $500^{\circ} \mathrm{C}$. The differences in $\alpha$ and $\beta$ relaxations for HPI-DB and HPI-mPD were mainly ascribed to the presence of carboxylic acid groups. A broad $\beta$ relaxation was seen from 100 to $300^{\circ} \mathrm{C}$ for both HPIs. This was mainly attributed to side group motion caused by the $\mathrm{CF}_{3}$ groups on 6FDA and the $\mathrm{OH}$ groups on $\mathrm{HAB}$. On the other hand, HPI-DB showed a unique second $\beta$ relaxation around $386^{\circ} \mathrm{C}$ that was mainly due to the movement of the carboxylic acid moiety on the DABA. The so-called $\alpha$ relaxation (main-chain relaxation), where a dramatic drop in storage modulus or the highest Tan $\delta$ appears, is commonly used to indicate the glass transition. Here, we define the temperature of the highest $\operatorname{Tan} \delta$ as the $\mathrm{T}_{\mathrm{g}}$, as such, the $\mathrm{T}_{\mathrm{g}}$ of HPI-DB was found to be $439^{\circ} \mathrm{C}$, much higher than that of HPI-mPD $\left(372^{\circ} \mathrm{C}\right)$, which was in good agreement with previous studies showing that MPD with incorporated copolyimide has a lower $\mathrm{T}_{\mathrm{g}}$ than DABA containing copolyimide.[25, 34] Such an observation can be attributed to the hydrogen bonding among carboxylic acid groups and hydroxyl groups. The polymer chains of HPI-mPD experienced a dramatic drop in storage modulus between 320 and $380^{\circ} \mathrm{C}$, whilst HPI-DB showed a recovery in storage modulus after passing the glass-rubber transition between 425 and $440^{\circ} \mathrm{C}$, suggesting the occurrence of in-situ thermal rearrangement with increased temperature.[33] 
TGA results of HPI-DB and HPI-mPD are shown in Figure 5-2(b). For both HPIs, the weight loss in the range of $400-520^{\circ} \mathrm{C}$ indicated $\mathrm{CO}_{2}$ emission by thermal rearrangement of imide to benzoxazole. The slight weight loss below $400^{\circ} \mathrm{C}$ for HPI-DB was related to the removal of residual solvent, as well as the release of $\mathrm{H}_{2} \mathrm{O}(\mathrm{m} / \mathrm{z}$ : 18$)$ and $\mathrm{CO}_{2}(\mathrm{~m} / \mathrm{z}$ : 44) according to mass spectroscopy (Figure 5-2(c)). The presence of the latter two components in mass spectroscopy implied potential cross-linking due to the formation of a dianhydride intermediate among the carboxylic acids in DABA which creates two phenyl free radicals as suggested by Qiu et al.[22]

(a)

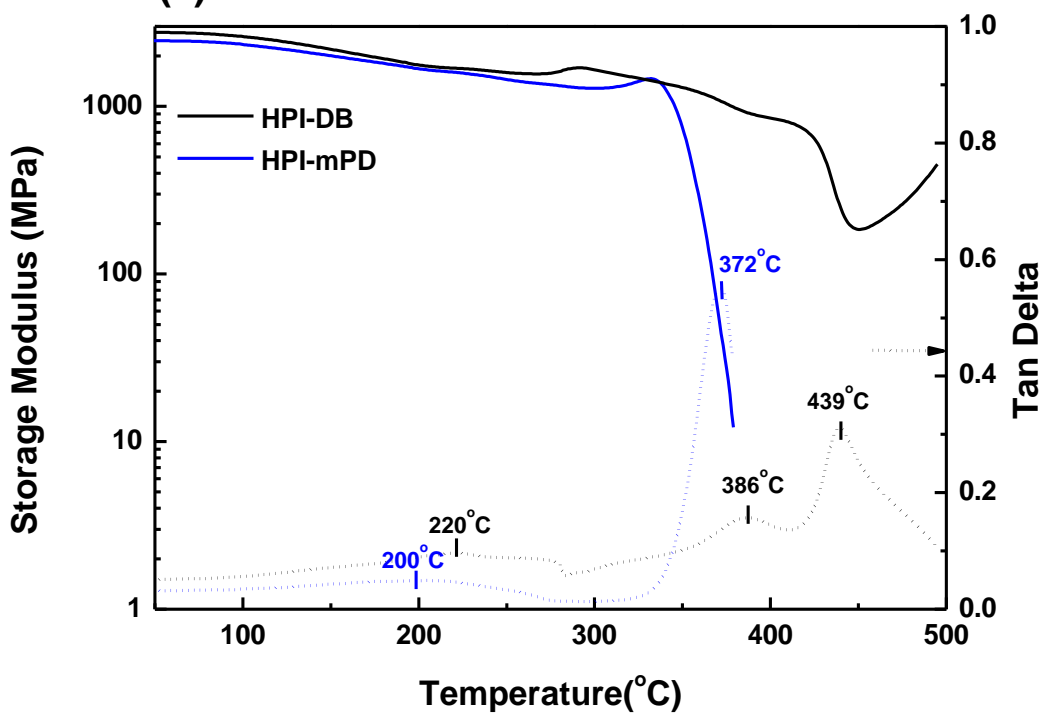


(b)
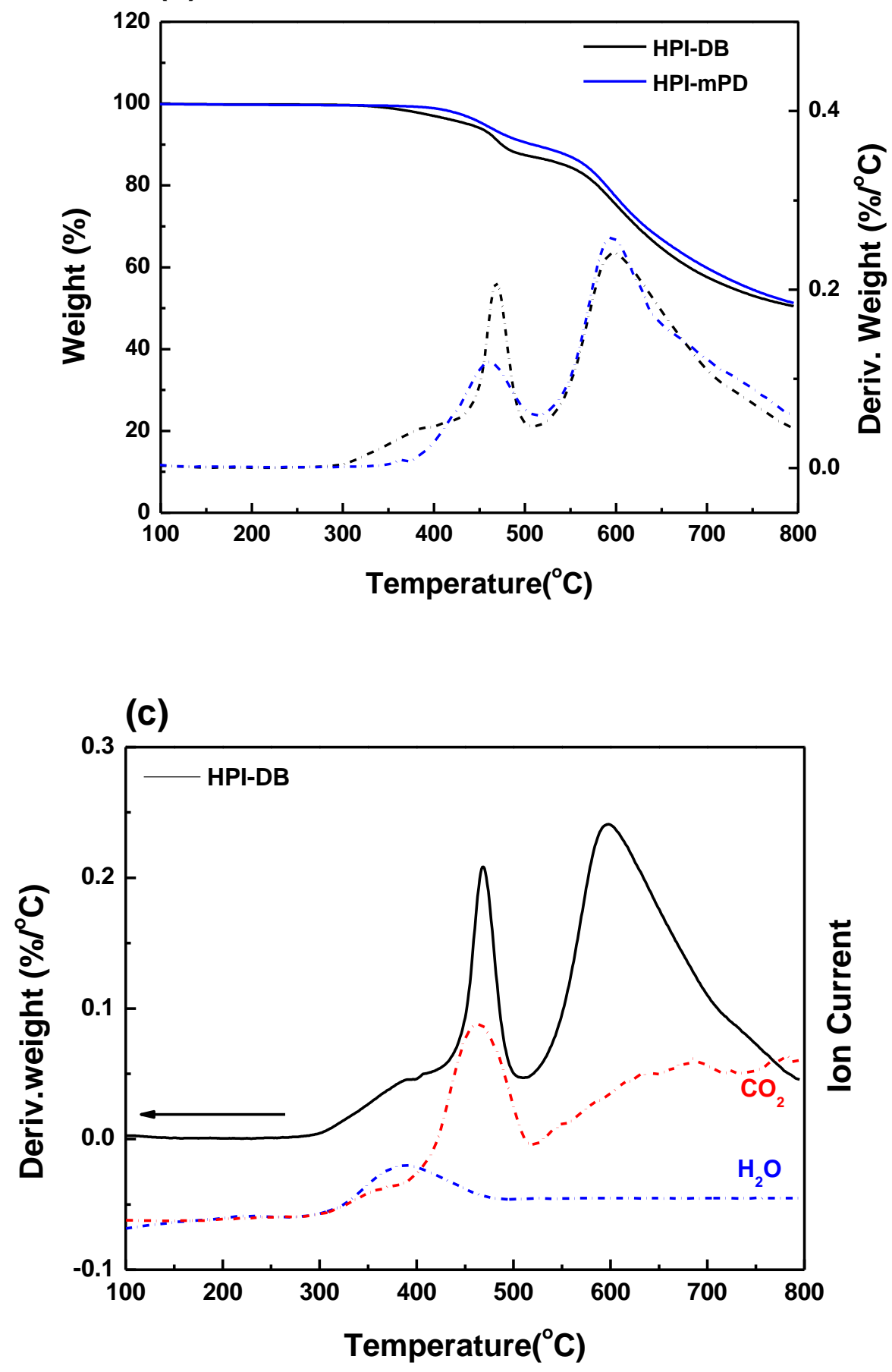

Figure 5-2 Thermal and dynamic behaviors of HPI-DB and HPI-mPD (a) storage modulus and 
Tan change as a function of temperature, measured by DMA $(50 \mathrm{oC} / \mathrm{min}, 1 \mathrm{~Hz})$, (b) weight changes and derivate weight change curves, measured by TGA (5oC/min, $99.9 \%$ N2 purge), and (c) TG-MS results of HPI-DB.

\subsubsection{Effect of Thermal Treatment Protocol on Cross-linking.}

As shown in Figure 5-3, the $30 \mu \mathrm{m}$ HPI-DB dense film, cast at $250^{\circ} \mathrm{C}$, completely dissolved in NMP with near zero gel fraction, indicating an absence of cross-linking. On the other hand, the HPI-DB dense film thermally treated at $300^{\circ} \mathrm{C}$ for more than $1 \mathrm{~h}$ showed a substantial increase in gel fraction, especially for the sample treated at $300^{\circ} \mathrm{C}$ for $3 \mathrm{~h}$, which displayed a

gel fraction of 99\%, indicating that the HPI-DB was sufficiently cross-linked. Interestingly, it was found that the degree of cross-linking was highly dependent on the thickness of the dense film. For the $30 \mu \mathrm{m}$ film, a $300^{\circ} \mathrm{C}$ treatment for $1 \mathrm{~h}$ was sufficient to increase the gel fraction to $98 \%$, while for the $50 \mu \mathrm{m}$ film, the gel fraction dropped to $52 \%$ using the same thermal treatment protocol. Consequently, the $300^{\circ} \mathrm{C}$ thermal treatment for $3 \mathrm{~h}$ was deemed the optimal sub- $\mathrm{T}_{\mathrm{g}}$ cross-linking condition for obtaining cross-linked hydroxyl copolyimides (XHPI-DB) in this study. 


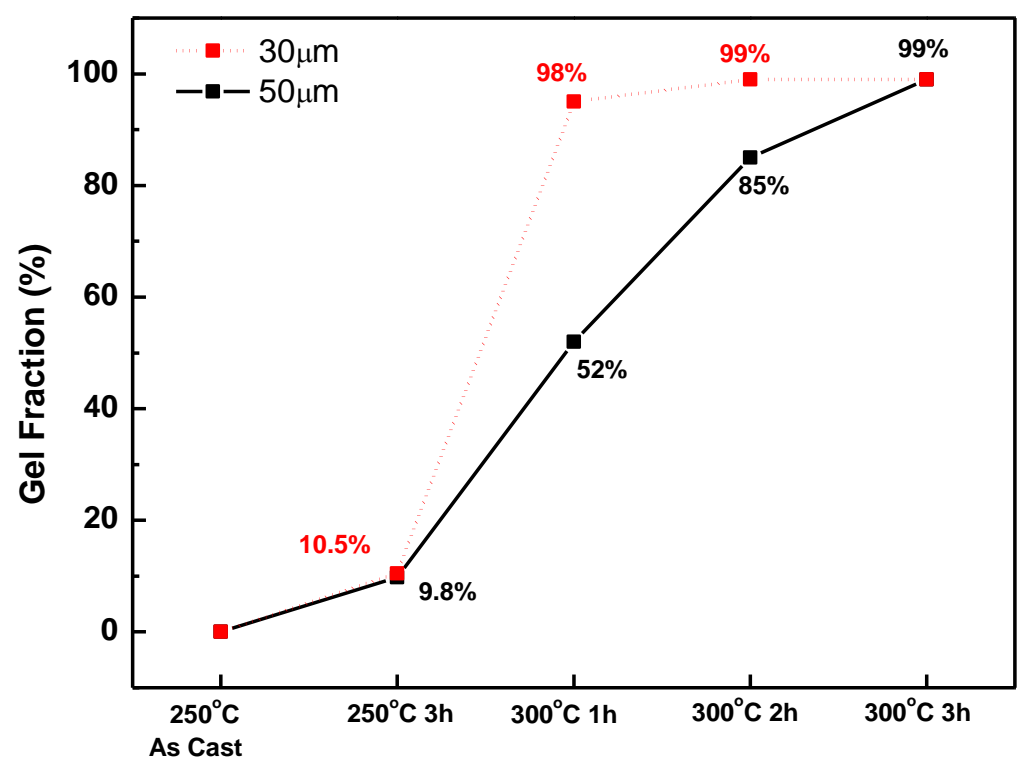

Figure 5-3 Gel fraction results for membranes treated under various sub- $\mathrm{T}_{\mathrm{g}}$ conditions.

\subsubsection{Sub- $T_{g}$ Thermal Cross-linking and Thermal Rearrangement of Cross-linked Hydroxyl Copolyimide (XHPI) into Poly(benzoxazole-co-imide) (XTR-PBOI).}

All membranes were first treated at $300^{\circ} \mathrm{C}$ for $3 \mathrm{~h}$ in argon to facilitate cross-linking of the hydroxyl polyimide (the optimal thermal treatment protocol for cross-linking as identified in the previous section), after which they were treated at $350,400,425$ or $450^{\circ} \mathrm{C}$ to allow for thermal rearrangement (Scheme 5-1). For comparison purposes, the HPI-mPD was also thermally treated under same treatment conditions (Scheme 5-2).

TGA and DMA were performed and the results are presented in Figure 5-4. As shown in Figure 5-4(a), for XHPI-DB, a significant weight loss was witnessed at temperatures between 
350 to $510^{\circ} \mathrm{C}$, the range in which thermal rearrangement took place. The $\mathrm{CO}_{2}$ emitted during this process corresponded to the weight loss. With the increased thermal treatment temperature, XTR-PBOIs showed a decrease in weight loss. More specifically, the XTR-425 and XTR-450 only showed a slight weight loss, indicating a high conversion rate from hydroxyl imide to benzoxazole. This observation was a clear indicator of the increased conversion degree with thermal rearrangement at higher temperatures. The changes in chemical structure caused by cross-linking and thermal rearrangements were evidenced from DMA results, as shown Figure 5-4(b). The variation in Tan $\delta$ for each dense film clearly showed distinct changes in $\beta$ relaxations from $100^{\circ} \mathrm{C}$ to $420^{\circ} \mathrm{C}$. The most noticeable difference was found in the Tan $\delta$ peak at $386^{\circ} \mathrm{C}$ of $\mathrm{HPI}-\mathrm{DB}$, which related to the $\mathrm{COOH}$ moiety. The amount of $\mathrm{OH}$ groups in $\mathrm{HAB}$ slowly decreased going from HPI-DB, to XHPI-DB and to XTR-350, eventually disappearing in the XTR-425 membrane. The DMA results also revealed changes in $T_{g}$ with thermal treatment temperatures, going from the low end of 439 and $440^{\circ} \mathrm{C}$ for HPI and XHPI-DB, respectively, to $445^{\circ} \mathrm{C}$ for XTR-350, and eventually to $461^{\circ} \mathrm{C}$ for the XTR-425. 
<smiles>Cc1cc(C(=O)O)cc(N2C(=O)c3ccc(C(C)(C)C(F)(F)F)cc3C2=O)c1</smiles>

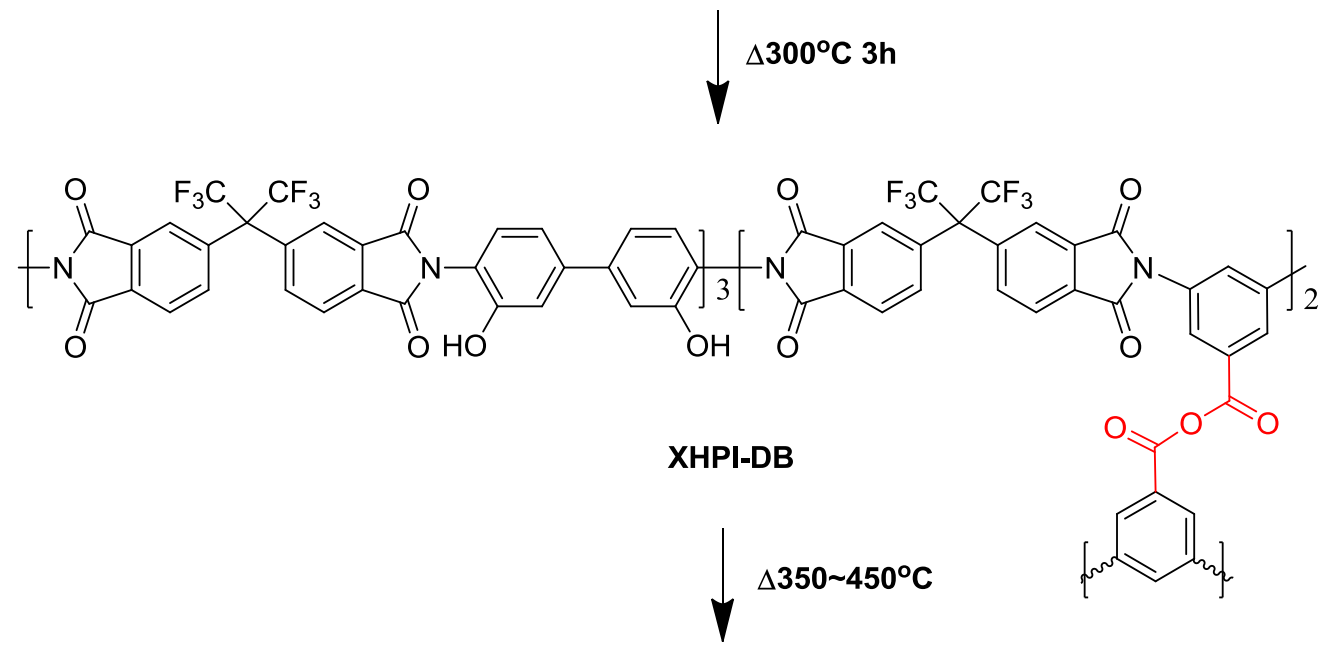

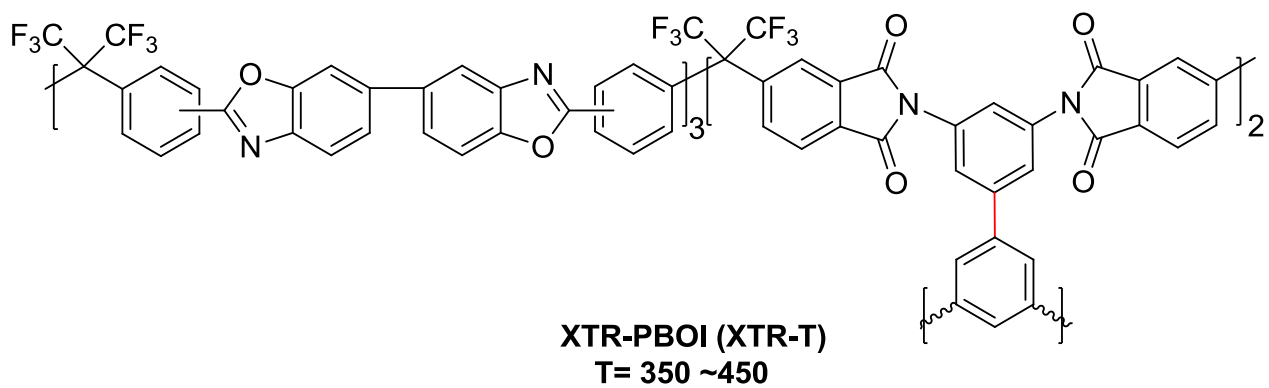

Scheme 5-1 Proposed reaction pathway and chemical structures of cross-linked thermally rearranged poly(benzoxazole-co-imide) membranes (XTR-PBOI) derived from hydroxyl copolyimide containing DABA (HPI-DB). 
<smiles>CC(C)(C)[13C](C)(C)C(C)(C)C</smiles>

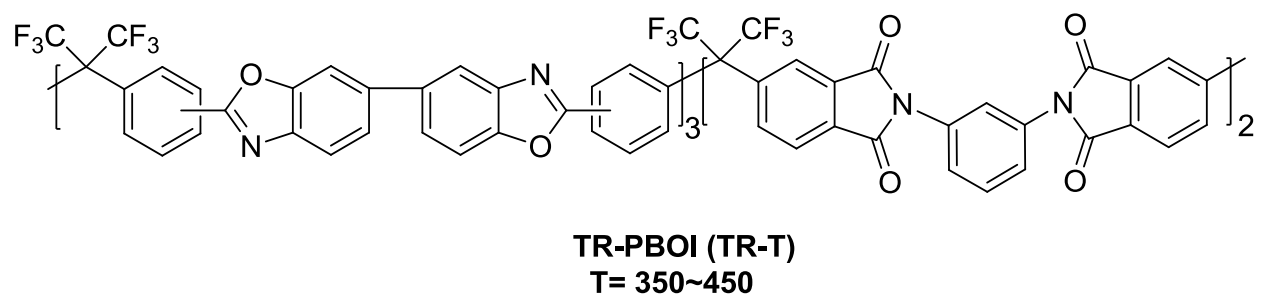

Scheme 5-2 Proposed reaction pathway and chemical structures of thermally rearranged poly(benzoxazole-co-imide) membranes (TR-PBOI) derived from hydroxyl copolyimide containing mPD (HPI-mPD).

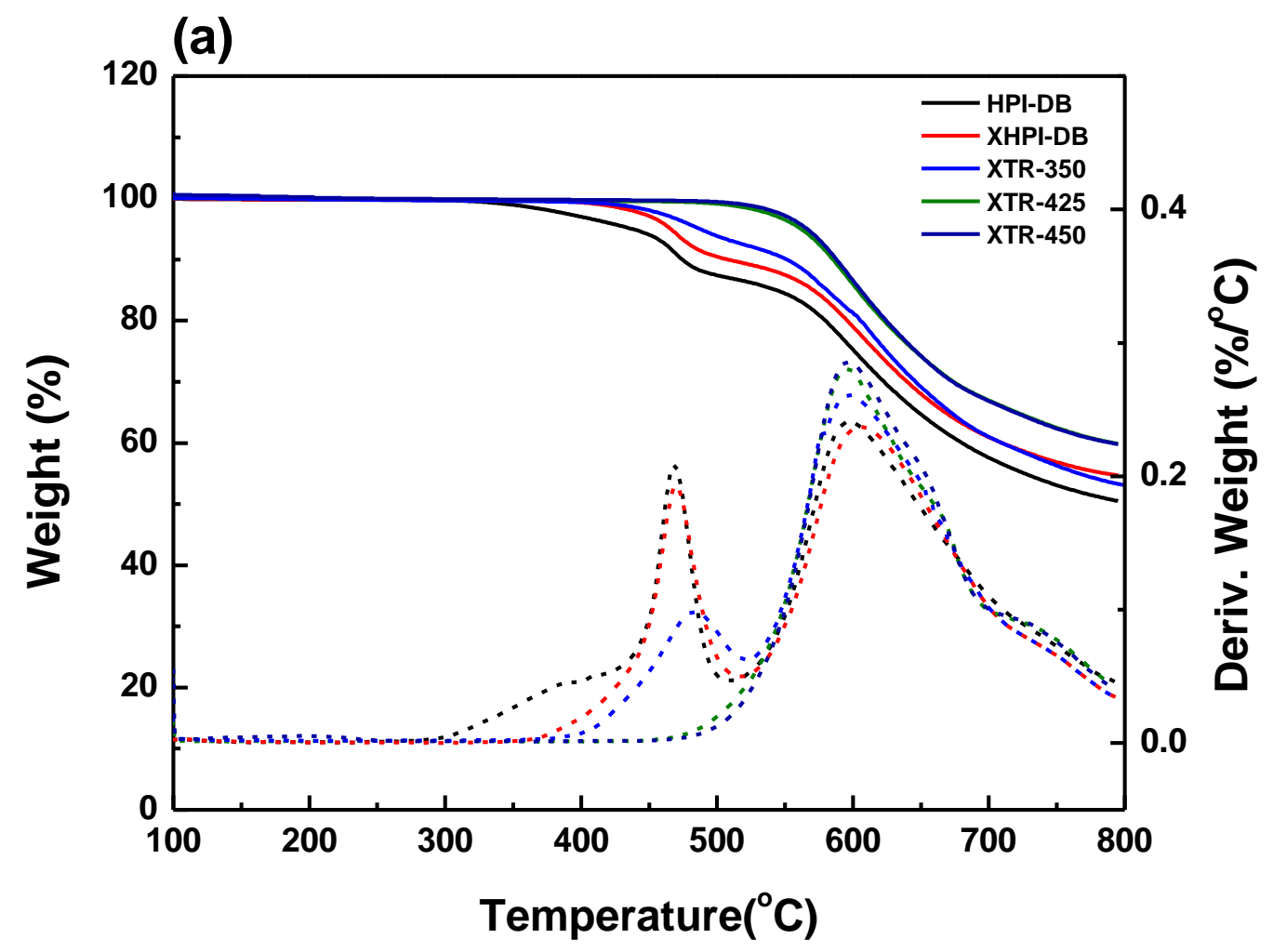




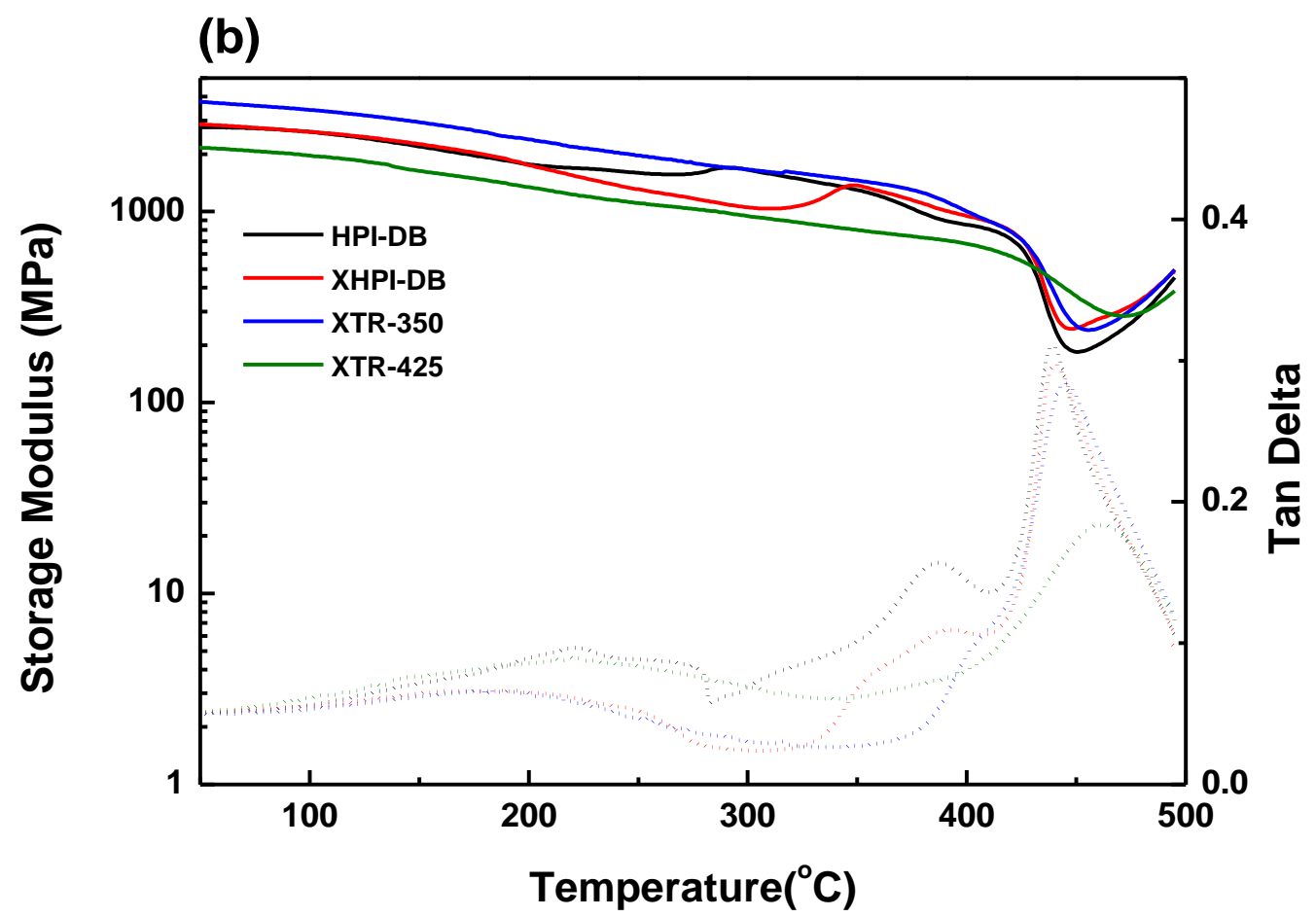

Figure 5-4 Thermal and dynamic behaviors of a variety of dense films (a) weight changes and derivative weight change curves measured by TGA (5oC/min, 99.9\% N2 purge) (b) storage modulus and Tan $\delta$ changes as a function of temperature, as measured by DMA $(5 \mathrm{oC} / \mathrm{min}, 1 \mathrm{~Hz})$.

ATR-FTIR was applied on both XTR and TR dense films to identify the formation of the benzoxazole moiety, which is an indicator of thermal rearrangement. As shown in Figure 5-5, the most noticeable changes were the diminishing imide stretching peaks at $1710 \mathrm{~cm}^{-1}(\mathrm{C}=\mathrm{O})$, $1097 \mathrm{~cm}^{-1}(\mathrm{~N}-\mathrm{C}-\mathrm{N})$, the hydroxyl group stretching peak around $3370 \mathrm{~cm}^{-1}$, and the increasing benzoxazole peaks at 1560,1480 , and $1055 \mathrm{~cm}^{-1}$ above $350^{\circ} \mathrm{C}$. These results provided clear evidence that thermal rearrangement was initiated at approximately $350^{\circ} \mathrm{C}$, which is in agreement with TGA results (Figure 5-4(a)). Furthermore, the imide peaks at 1782 and 1715 $\mathrm{cm}^{-1}$ remain at temperatures above $350^{\circ} \mathrm{C}$, mainly due to the presence of the $40 \%$ imide 
moieties in the main-chains. On the other hand, the peaks related to the hydroxyl groups completely disappeared above $350^{\circ} \mathrm{C}$. Based on these above observations, the dense films prepared at temperatures above $350^{\circ} \mathrm{C}$ clearly underwent thermal rearrangement and were therefore labeled as XTR-350, 400, 425, and 450 for films prepared from cross-linkable HPIDB, those prepared from uncross-linkable HPI-mPD were labeled as TR-350, 400, 425 and 450.

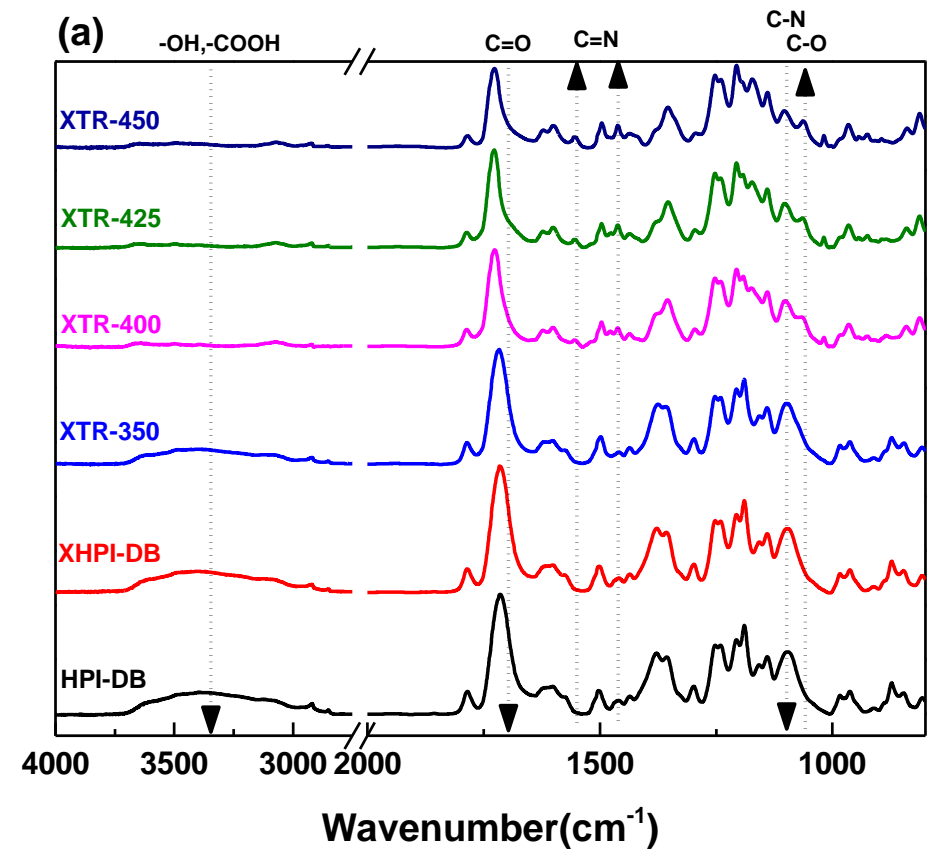




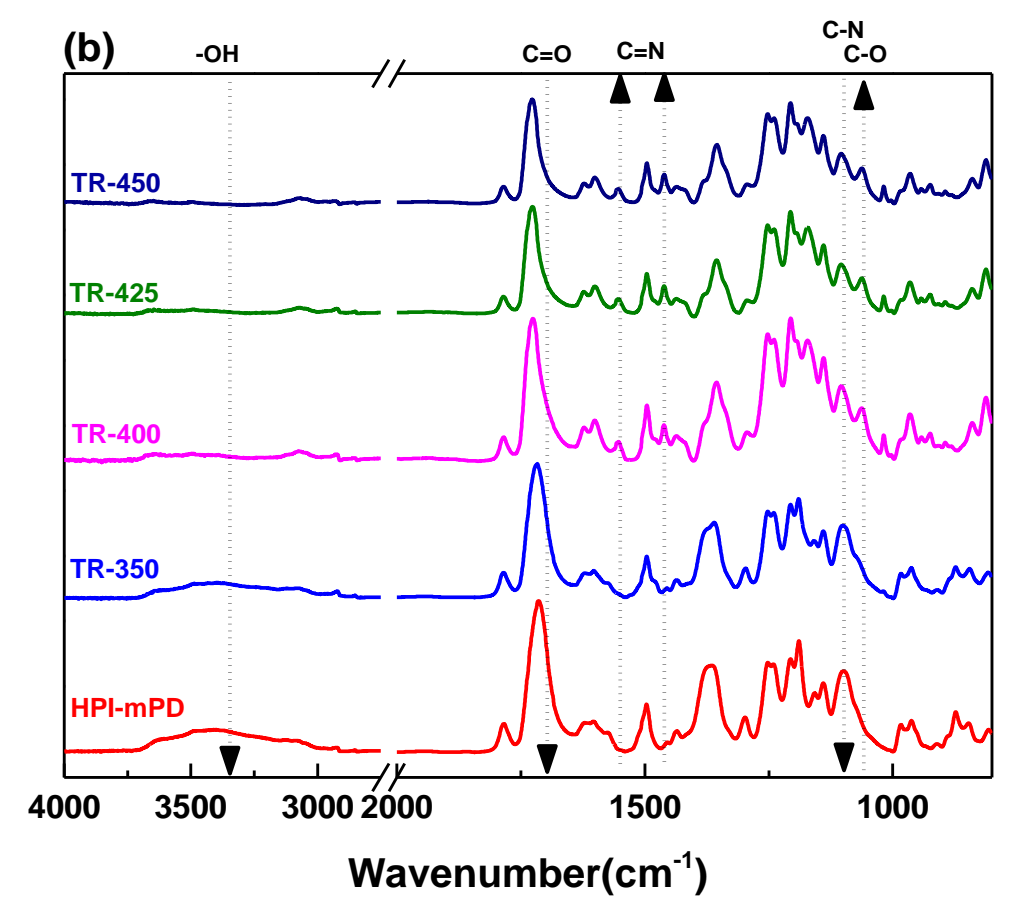

Figure 5-5 ATR-FTIR spectra of (a) XTR-PBOIs compared with to precursor HPI-DB and XHPI-DB, and (b) TR-PBOIs compared with to precursor HPI-mPD. Arrows indicate increases in the intensity of the infrared adsorption bands. 
The percentage conversion $(\% C)$ during thermal rearrangement was calculated as well. Previous studies reveal that the conversion rate $(\% C)$ is highly dependent on the thermal treatment protocols, therefore the amount of the benzoxazole structure in each TR or XTRPBOI will vary depending on the thermal treatment conditions.[6, 8] Most current studies calculate $\% C$ using data obtained from TGA-isotherms by comparing the actual weight loss over the theoretical weight loss.[6] A similar approach was adopted in this study for the calculation of the $\% C$ for XTR-PBOIs and TR-PBOIs; the results are summarized in Table 51. The theoretical weight loss of XTR-PBOI converted from HPI-DB was $11.82 \%$, of which 3\% was from DABA cross-linking and 8.82\% was from thermal rearrangement. Assuming complete cross-linking of the XTR-450, the \%C value (from HPI to PBO) was 71\% (actual weight loss: 9.244\%, weight loss by TR conversion: $6.244 \%$ ). It was found that the conversion rate of TR-450 (92\%) was higher than that of XTR-450 (71\%), which was mainly due to restricted chain mobility caused by the more rigid HPI-DB limiting the TR conversion rate.[6]

Table 5-1 Weight loss and TR conversion rates for different dense films.

\begin{tabular}{|c|c|c|c|c|c|c|}
\hline \multirow[t]{2}{*}{ Polymer } & $\begin{array}{c}\text { Actual } \\
\text { weight } \\
\text { loss, } \\
\text { Wactual,1 }\end{array}$ & $\begin{array}{c}\text { TR weight } \\
\text { loss }^{\mathrm{a}} \\
\mathrm{W}_{\text {actual,2 }}\end{array}$ & $\% \mathrm{C}$ & \multirow[t]{2}{*}{ Polymer } & $\begin{array}{c}\text { Actual } \\
\text { weight loss } \\
\text { W }_{\text {actual,3 }}\end{array}$ & $\% \mathrm{C}^{\mathrm{c}}$ \\
\hline & $(\%)$ & $(\%)$ & $(\%)$ & & $(\%)$ & $(\%)$ \\
\hline XTR -350 & 0.73 & - & - & TR -350 & 0.79 & 8.70 \\
\hline XTR -400 & 4.01 & 1.01 & 11.4 & TR -400 & 3.62 & 39.9 \\
\hline XTR -425 & 6.28 & 3.28 & 37.2 & TR -425 & 6.48 & 71.3 \\
\hline XTR -450 & 9.24 & 6.24 & 70.8 & TR -450 & 8.36 & 92.0 \\
\hline $\begin{array}{l}\text { omplete DAB } \\
\text { s. } \mathrm{W}_{\text {actual }, 2}=\mathrm{V} \\
00 * \mathrm{~W}_{\text {actual, }, 2} / \mathrm{Y} \\
00 * \mathrm{~W}_{\text {actual, } 3} / \mathrm{W}\end{array}$ & $\begin{array}{l}\text { oss-linki } \\
\text { when th } \\
\text { when the }\end{array}$ & assumed wh & theo) $\mathrm{e}$ & t loss is witl & $3 \%$ of the the & \\
\hline
\end{tabular}




\subsubsection{Effect of Cross-linking on Physical Properties.}

The effects of cross-linking on membrane shrinkage and the $d$-spacing of polymer chains are summarized in Table 5-2 and Figure 5-6. For amorphous polymers, previous studies attributed their shrinkage stresses to the disruption of intermolecular interactions between the frozen elastic chains.[35] Therefore, it is assumed that the TR polymers, which were treated at temperatures higher than the $\mathrm{T}_{\mathrm{g}}$, underwent chain relaxation and orientation, thereby diminishing their intermolecular interactions and consequently resulting in their higher shrinkage percent. As noted in Table 5-2, the shrinkage of both HPI-DB and HPI-mPD membranes gradually increased with increasing temperatures. Furthermore, the degree of shrinkage was significantly lower for the case of the XTR dense films compared to their TR counterparts. These results suggested that the XTR polymers showed a higher resistance to intermolecular chain disruptions due to their being cross-linked. Such behavior might be attributed to the restricted inter-chain relaxation and orientation.

The inter-chain distance distributions of all samples measured by WAXD are shown in Figure 5-6, and the representative average inter-chain distances ( $d$-spacing) of each sample are summarized in Table 5-2. The results clearly showed that the $d$-spacing of the XTR polymers increased with increasing thermal treatment temperatures, while the $d$-spacing of the TR polymers remained almost the same at temperatures above $350^{\circ} \mathrm{C}$. More specifically, the initial increase in $d$-spacing of the HPI-DB from 0.550 to $0.592 \mathrm{~nm}$ was attributed to the cross-linking. Chain packing order was disrupted by the formation of anhydride cross-links and the partial decarboxylation of the cross-linked structure.[22] The subsequent $d$-spacing increase of the XHPI-DB (0.592 nm) to XTR-PBOIs (up to $0.629 \mathrm{~nm}$ ) was caused by thermal rearrangement 
and cross-linking by decarboxylation. Consequently, the XTR-450 dense film achieved a 29.5\% increase in $d$-spacing while the uncross-linked TR-450 showed only a $4 \%$ increase. This observation was in good agreement with previous studies on intrinsically cross-linked tPBO, which showed a significantly greater increase in $d$-spacing and FFV than uncross-linked aPBO.[12]

Table 5-2 Physical property comparisons of XTR-PBOIs and TR-PBOIs.

\begin{tabular}{cccc}
\hline \multirow{2}{*}{ Polymer } & Shrinkage & d-spacing & $\Delta$ d-spacing \\
\cline { 2 - 4 } & $(\%)$ & $(\mathrm{nm})$ & $(\%)$ \\
\hline HPI-DB & - & 0.550 & - \\
XHPI-DB & 0.5 & 0.592 & 7.1 \\
XTR -350 & 2.0 & 0.629 & 14.4 \\
XTR -400 & 8.1 & 0.642 & 16.7 \\
XTR -425 & 9.4 & 0.711 & 29.3 \\
XTR -450 & 12.2 & 0.713 & 29.5 \\
HPI-mPD & - & 0.633 & - \\
TR -350 & 12.6 & 0.634 & 0.1 \\
TR -400 & 17.5 & 0.658 & 3.8 \\
TR -425 & 18.4 & 0.661 & 4.3 \\
TR -450 & 18.4 & 0.652 & 4.1
\end{tabular}


(a)

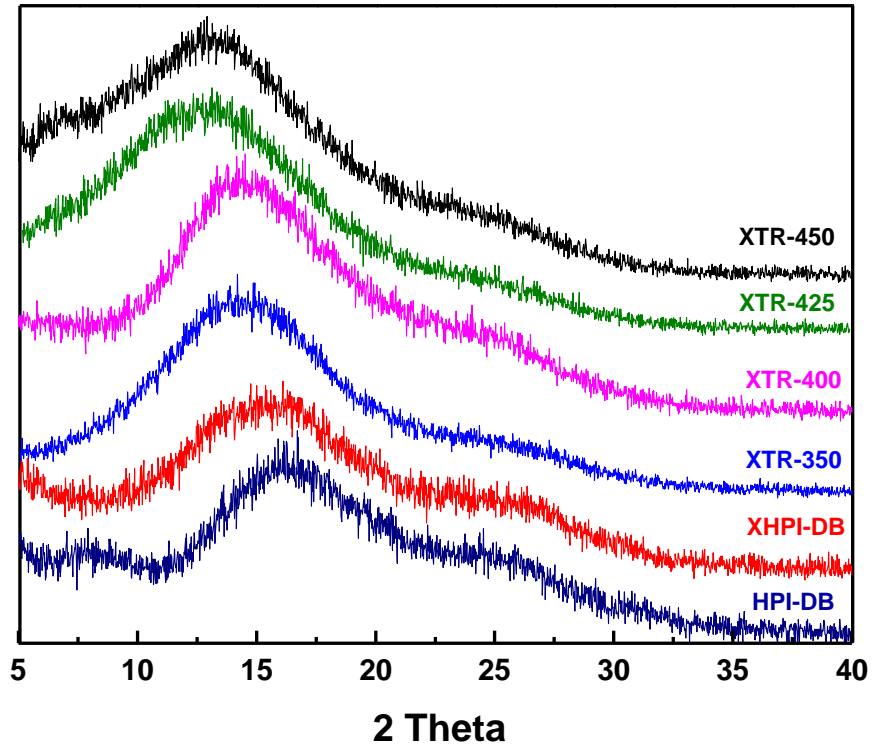

(b)

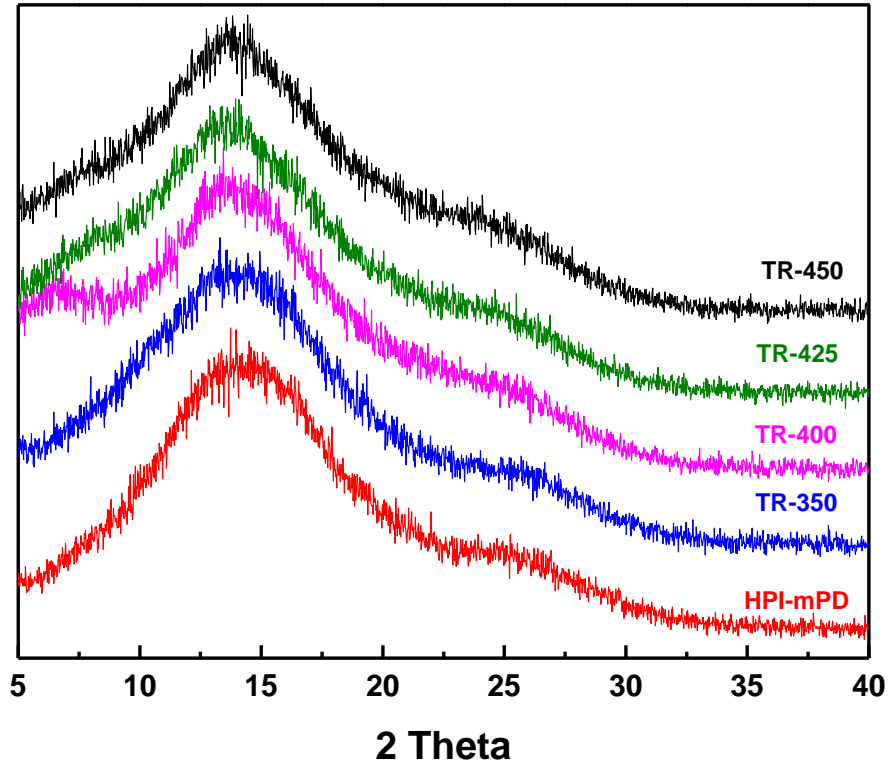

Figure 5-6 Wide-Angle X-ray Diffraction (WAXD) profiles of (a) XTR-PBOIs and (b) TRPBOIs at different thermal treatment temperatures. 


\subsubsection{Effect of Cross-linking on Pure Gas Transport Properties.}

The pure gas permeation results are summarized in Table 5-3. In addition, the profiles of $\mathrm{CO}_{2}$ permeability for XTR-PBOIs and TR-PBOIs, as a function of thermal treatment temperature, are shown in Figure 5-7. The results showed that the $\mathrm{CO}_{2}$ permeabilities of both polymers increased with temperature, but the $\mathrm{CO}_{2}$ permeability of XTR-PBOIs were higher than those of TR-PBOIs. Towards the end of the thermal treatment, XTR-450 saw a 25-fold higher $\mathrm{CO}_{2}$ permeability (169.7 Barrer) than its corresponding precursor, while the $\mathrm{CO}_{2}$ permeability of TR-450 (44.6 Barrer) was only twice higher than its HPI-mPD precursor (15.6 Barrer). Furthermore, it was found that the increase in gas permeabilities was highly correlated with the increase in $d$-spacing of the polymer chains (Table 5-2 and Figure 5-6). These results clearly suggested that cross-linking encouraged the formation of a polymer network that incorporated DABA in the HPI-DB. These functioned as a "pillar-like" cross-linker, effectively keeping the main polymer chains apart and therefore resulting in a substantially increased amount of free volume and extraordinary gas permeabilities compared with uncross-linked HPI-mPD.

In terms of ideal gas selectivity, a general trend of a slight decrease in selectivity with increased treatment temperature was observed, which was primarily attributed to the enlarged free volume and chain distances. The $\mathrm{CO}_{2}$ permeabilities and $\mathrm{CO}_{2} / \mathrm{CH}_{4}$ selectivities for XTRPBOIs and TR-PBOIs at different thermal treatment temperatures are plotted in Figure 5-8. TR-PBOIs derived from HPI-mPD showed a typical permeability-selectivity trade-off relationship of decreased selectivity with increased permeability. All polymers fell below the 1991 Robeson upper bound.[36] In terms of the cross-linked polymers, the typical trade-off 
relationship was found when the dense films were treated below $400{ }^{\circ} \mathrm{C}$. Above this temperature, the $\mathrm{CO}_{2} / \mathrm{CH}_{4}$ selectivity had recovered (XTR-425 and 450), and subsequently, the XTR-450 crossed over the 1991 Robeson upper bound. Interestingly, the XTR-450 showed a much higher permeability and selectivity than the homo TR-PBO polymer based on 6FDAHAB,[6] while the TR-450 showed a lower permeability.

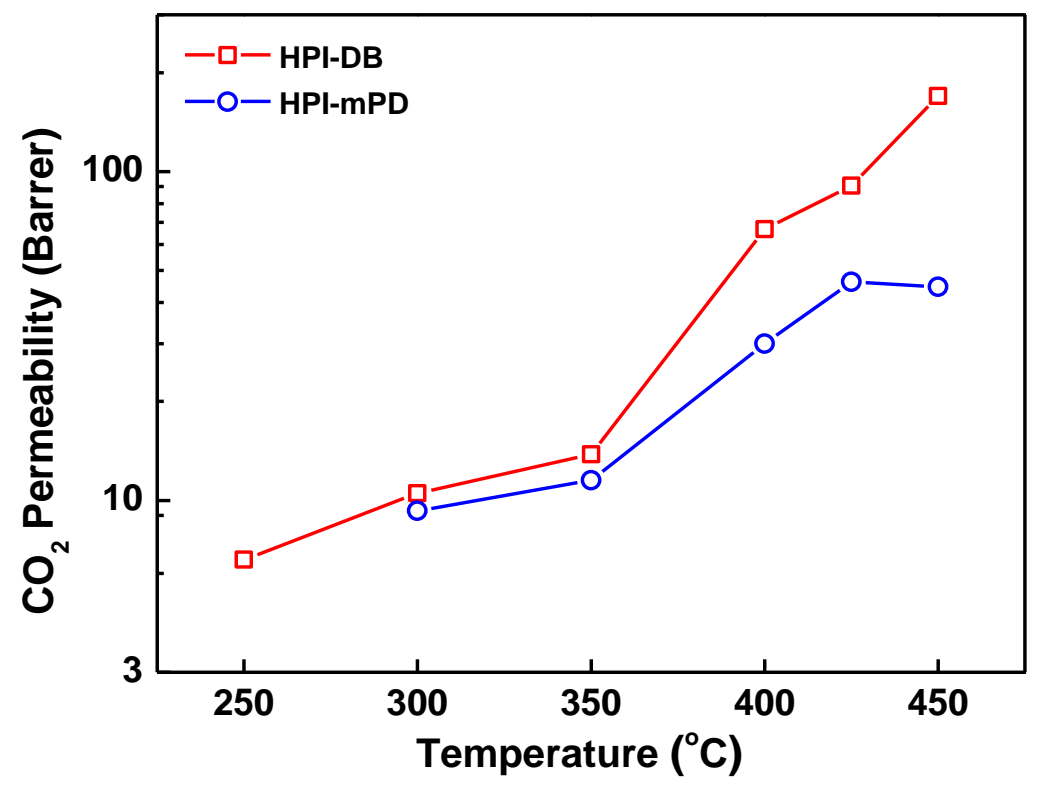

Figure 5-7 $\mathrm{CO}_{2}$ permeability profiles of XTR-PBOIs and TR-PBOIs as a function of thermal treatment temperature. 
Table 5-3 Pure gas permeabilities of HPI-DB and HPI-mPD membranes and thermally rearranged XTR-PBOI an d TR-PBOI membranes using the time-lag method $\left(30^{\circ} \mathrm{C}, 760\right.$ torr $)$

a the gas permeability and selectivity results were referred from [22]

\begin{tabular}{ccccccccccc}
\hline & \multicolumn{3}{c}{ Gas Permeability (Barrer) } & \multicolumn{5}{c}{ Ideal Selectivity $(\alpha)$} \\
\cline { 2 - 11 } & $\mathrm{He}$ & $\mathrm{H}_{2}$ & $\mathrm{O}_{2}$ & $\mathrm{~N}_{2}$ & $\mathrm{CO}_{2}$ & $\mathrm{CH}_{4}$ & $\mathrm{O}_{2} / \mathrm{N}_{2}$ & $\mathrm{CO}_{2} / \mathrm{N}_{2}$ & $\mathrm{CO}_{2} / \mathrm{CH}_{4}$ & $\mathrm{H}_{2} / \mathrm{CO}_{2}$ \\
\hline HPI-DB & 34.9 & 26.1 & 1.58 & 0.22 & 6.60 & 0.12 & 7.18 & 30.0 & 55.9 & 3.96 \\
XHPI-DB & 50.2 & 37.4 & 2.46 & 0.37 & 10.5 & 0.21 & 6.70 & 28.7 & 50.1 & 3.55 \\
XTR-350 & 57.9 & 47.5 & 4.46 & 0.53 & 13.8 & 0.47 & 6.35 & 26.1 & 29.2 & 3.44 \\
XTR-400 & 112.2 & 118.2 & 14.9 & 2.72 & 66.8 & 2.52 & 5.48 & 24.6 & 26.5 & 1.77 \\
XTR-425 & 121.2 & 139.4 & 18.1 & 3.77 & 90.7 & 3.09 & 4.79 & 24.1 & 29.3 & 1.48 \\
XTR-450 & 210.8 & 246.5 & 35.0 & 7.33 & 169.7 & 4.46 & 4.78 & 23.2 & 38.0 & 1.45 \\
\hline HPI-mPD & 49.9 & 36.6 & 3.02 & 0.41 & 9.28 & 0.14 & 7.37 & 22.6 & 66.3 & 3.94 \\
TR-350 & 53.4 & 41.2 & 3.71 & 0.59 & 15.6 & 0.24 & 6.32 & 26.5 & 65.4 & 3.57 \\
TR-400 & 73.3 & 66.8 & 6.75 & 1.28 & 29.9 & 0.67 & 5.26 & 23.3 & 44.4 & 2.23 \\
TR-425 & 99.5 & 93.8 & 10.1 & 1.94 & 46.3 & 1.04 & 5.20 & 23.8 & 44.3 & 2.03 \\
TR-450 & 89.6 & 87.8 & 9.55 & 1.81 & 44.6 & 1.05 & 5.26 & 24.6 & 42.5 & 1.97 \\
\hline DAM-DABA (3:2) $^{\mathrm{a}}$ & 357.0 & - & 98.0 & 25.2 & 485.4 & 18.1 & 3.90 & 19.3 & 26.8 & - \\
\hline HAB aPBO & 84.6 & 86.5 & 10.8 & 2.2 & 59.0 & 1.6 & 4.80 & 26.3 & 36.5 & 1.47 \\
\hline
\end{tabular}

${ }^{\mathrm{b}}$ the gas permeability and selectivity results were referred from [6] 


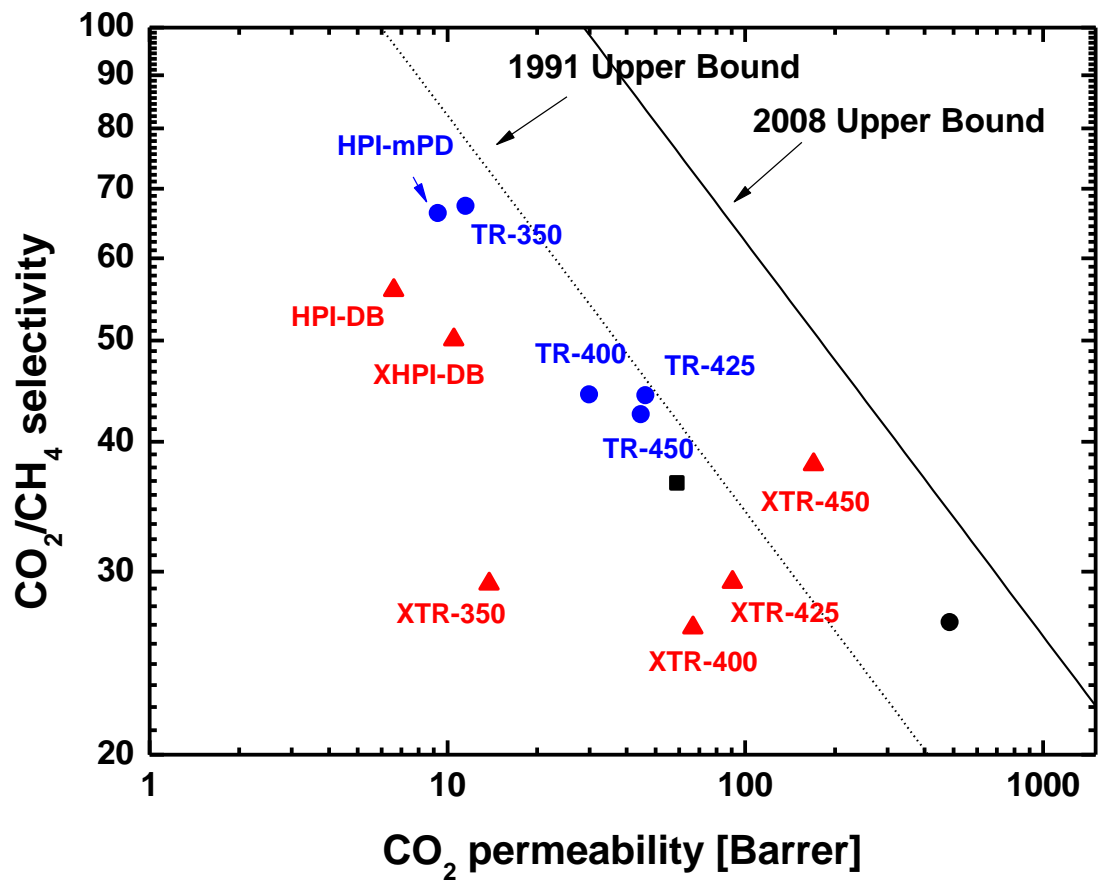

Figure 5-8 The Robeson plot of $\mathrm{CO}_{2}$ permeability and $\mathrm{CO}_{2} / \mathrm{CH}_{4}$ ideal selectivity for co mparing XTR-PBOIs $(\boldsymbol{\Delta})$ and TR-PBOIs $(\bullet)$ with several comparable polymer membr anes: aPBO based on 6FDA-HAB (๘), 6FDA-DAB-DABA(3:2) (•).[36, 37]

The $\mathrm{CO}_{2}$ and $\mathrm{CH}_{4}$ sorption isotherms are shown in Figure 5-9. All sorption isotherms displayed typical dual-mode sorption for glassy polymers. As shown in Figure 5-9(a) and (b), $\mathrm{CO}_{2}$ and $\mathrm{CH}_{4}$ sorption isotherm curves for XTR-450 and TR-450 were located above that of HPI-DB and HPI-mPD. Interestingly, the sorption isotherms for XHPI-DB were located below HPI-DB, indicating that cross-linking caused lower gas solubility. According to the dual-mode solubility parameters summarized in Table 5-4, TR-450, derived from HPI-mPD, exhibited an increased Henry's law constant $\left(\mathrm{k}_{\mathrm{D}}\right)$ and Langmuir capacity $\left(\mathrm{C}^{\prime}{ }_{\mathrm{H}}\right)$. However, the conversion to rigid benzoxazoles reduced the Langmuir affinity (b) between $\mathrm{CO}_{2}$ and the polymer matrix, 
which was in agreement with the sorption behaviors of TR-PBOIs.[38] On the other hand, cross-linked XHPI-DB resulted in reduced $\mathrm{k}_{\mathrm{D}}$ and $\mathrm{C}^{\prime}{ }_{\mathrm{H}}$ parameters, indicating that cross-linking prohibited the swelling of the polymer matrix. Additionally, the reductions in these two parameters were also partially attributed to the loss in excess free volume by thermal annealing. Further increasing the temperature, to promote thermal rearrangement, only led to marginal increases in $\mathrm{k}_{\mathrm{D}}$ from 1.07 (XHPI-DB) to 1.15 (XTR-450) and a significant increase in $\mathrm{C}_{\mathrm{H}}$ from 28.9 (XHPI-DB) to 38.2 (XTR-450). The b parameters kept decreasing from 0.71 (XHPI-DB) to 0.40 (XTR-450) due to the formation of rigid benzoxazole groups.

The solubility and diffusivity coefficients are summarized in Table 5-5. For the crosslinkable dense films, a clear trend of increased diffusivity coefficient as a function of temperature was observed, and the increase was more pronounced during the thermal rearrangement than during cross-linking. This observation was in good agreement with the permeability results as well as the $d$-spacing results. The drops in solubility coefficients after cross-linking and thermal rearrangement were mainly attributed to the decreased Langmuir affinity (b). The increase in $d$-spacing and free volume led to decreased diffusivity selectivity. For the uncross-linkable dense films, the improvement in diffusivity coefficient was more moderate due to the absence of cross-linking. Owing to the cross-linking, the diffusivity coefficient increased 18-fold from 0.80 (XHPI-DB) to 14.1 (XTR-450) during thermal rearrangement. This was more pronounced than the 6-fold increase in diffusivity coefficient due to the absence of cross-linking. 

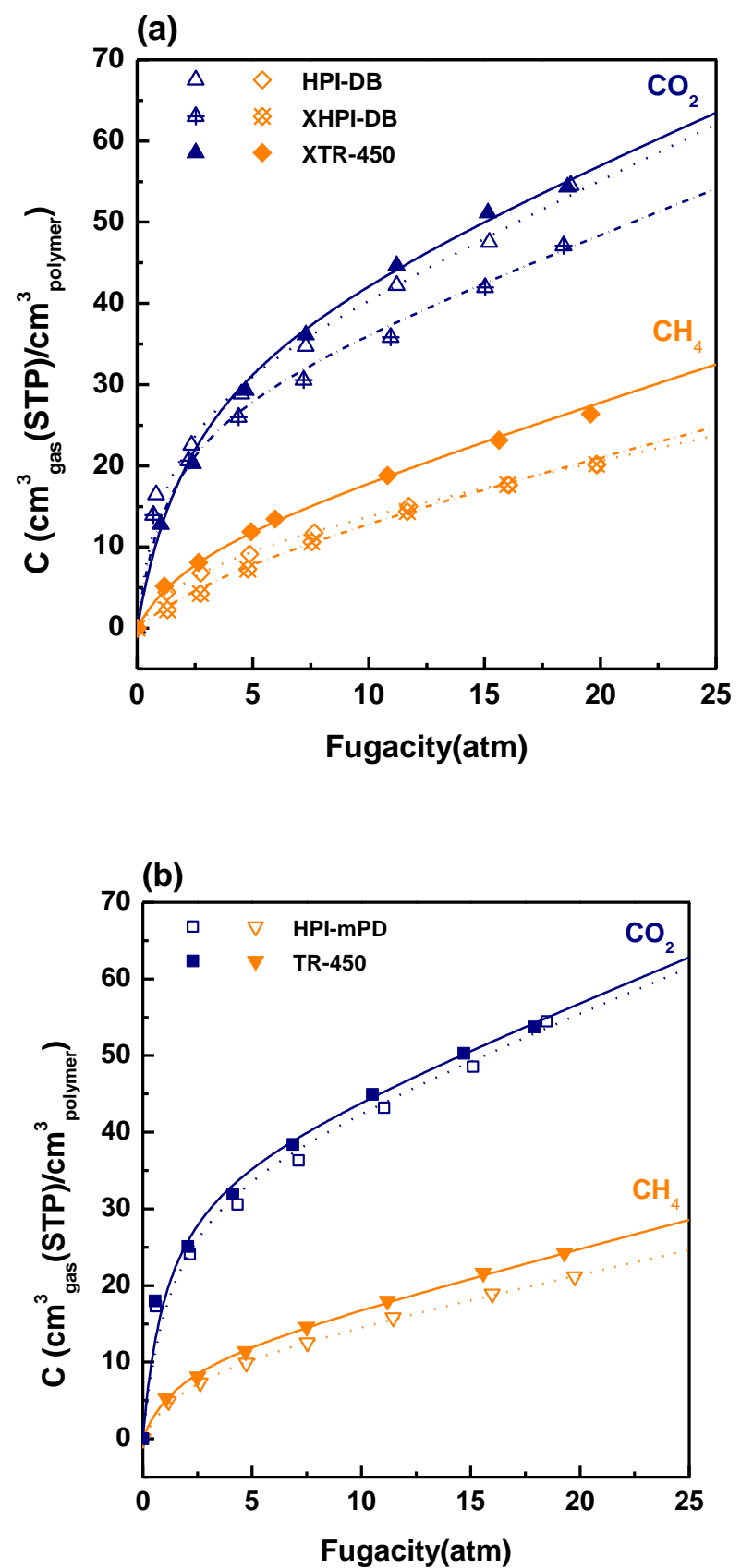

Figure 5-9 Sorption isotherms of CO2 and CH4 for (a) HPI-DB, XHPI-DB, and XTR450 as representatives of XTR-PBOI (b) HPI-mPD and TR-450 are representative of XTR- 
PBOI.

Table 5-4 Dual-mode sorption model parameters for pure $\mathrm{CO}_{2}$ and $\mathrm{CH} 4$ in XTR-PBOI and TR-PBOI membranes and precursor membranes a

\begin{tabular}{|c|c|c|c|c|c|c|}
\hline & \multicolumn{3}{|c|}{$\mathrm{CO}_{2}$} & \multicolumn{3}{|c|}{$\mathrm{CH}_{4}$} \\
\hline & $\mathrm{k}_{\mathrm{D}}$ & $\mathrm{b}$ & $\mathrm{C}_{\mathrm{H}}^{\prime}$ & $\mathrm{K}_{\mathrm{D}}$ & $\mathrm{b}$ & $\mathrm{C}^{\prime}{ }_{\mathrm{H}}$ \\
\hline HPI-DB & 1.32 & 0.80 & 30.5 & 0.60 & 0.40 & 9.65 \\
\hline XHPI-DB & 1.07 & 0.71 & 28.9 & 0.70 & 0.19 & 8.86 \\
\hline XTR -450 & 1.15 & 0.40 & 38.2 & 0.90 & 0.04 & 11.0 \\
\hline HPI-mPD & 1.12 & 0.77 & 35.2 & 0.61 & 0.50 & 10.1 \\
\hline TR -450 & 1.37 & 0.53 & 35.5 & 0.73 & 0.60 & 11.0 \\
\hline
\end{tabular}

${ }^{\mathrm{a}} \mathrm{K}_{\mathrm{D}}\left(\mathrm{cm} 3 \mathrm{stP}\left(\mathrm{cm}^{3}{ }_{\text {polymer }}\right.\right.$ bar) $)$, b (1/bar), C' ${ }^{\prime}\left(\mathrm{cm}^{3}{ }_{\text {STP }} / \mathrm{cm}^{3}{ }^{3}\right.$ polymer $)$

Table 5-5. $\mathrm{CO}_{2}$ and $\mathrm{CH}_{4}$ diffusion coefficients (D), solubility coefficients (S), permeab ilities (P), diffusion selectivities $\left(\alpha_{D}\right)$, and solubility selectivities $\left(\alpha_{S}\right)$ for XTR-PBOI and TR-PBOI membranes and precursor membranes

\begin{tabular}{|c|c|c|c|c|c|c|c|c|c|}
\hline & \multicolumn{2}{|c|}{$\mathrm{D}^{\mathrm{a}}$} & \multicolumn{2}{|c|}{$S^{b}$} & \multicolumn{2}{|c|}{ P } & \multicolumn{3}{|c|}{$\alpha_{\mathrm{CO} 2} /{ }_{\mathrm{CH} 4}$} \\
\hline & $\mathrm{CO}_{2}$ & $\mathrm{CH}_{4}$ & $\mathrm{CO}_{2}$ & $\mathrm{CH}_{4}$ & $\mathrm{CO}_{2}$ & $\mathrm{CH}_{4}$ & $\alpha_{D}$ & $\alpha_{S}$ & $\alpha$ \\
\hline HPI-DB & 0.44 & 0.04 & 14.9 & 3.36 & 6.60 & 0.12 & 12.4 & 4.43 & 55.0 \\
\hline XHPI-DB & 0.80 & 0.10 & 13.1 & 2.11 & 10.5 & 0.21 & 8.09 & 6.18 & 50.0 \\
\hline XTR -450 & 14.1 & 3.37 & 12.1 & 1.32 & 169.7 & 4.46 & 4.17 & 9.12 & 38.0 \\
\hline HPI-mPD & 0.56 & 0.04 & 16.4 & 3.98 & 9.28 & 0.14 & 16.0 & 4.13 & 66.3 \\
\hline TR -450 & 3.26 & 0.22 & 13.7 & 4.86 & 44.6 & 1.05 & 15.1 & 2.82 & 42.5 \\
\hline
\end{tabular}

${ }^{\text {a }}$ Diffusivity coefficient (D) $\left(10^{-8} \mathrm{~cm}^{2} / \mathrm{s}\right)$ is calculated from $\mathrm{P}=\mathrm{DS}$.

b Solubility coefficient $(\mathrm{S})\left(10^{-2} \mathrm{~cm}^{3} / \mathrm{cm}^{3} \mathrm{cmHg}\right)$ is obtained from sorption isotherm experiments and calculated using Equation (5-8) and data from Table 5-3 when fugacity equals 1 bar.

\subsubsection{Effect of Cross-linking on Mixed Gas Permeation and Plasticization.}

A 1:1 volume ratio of $\mathrm{CO}_{2} / \mathrm{CH}_{4}$ gas mixture was used to evaluate the effect of cross-linking on plasticization mitigation under a mixed-gas environment. As shown in Figure $5-10, \mathrm{CO}_{2}$ and $\mathrm{CH}_{4}$ permeabilities of both membranes slightly dropped with increased pressure, which was related to the dual-mode sorption. Within the range of pressures assessed up to $36 \mathrm{bar}\left(\mathrm{CO}_{2}\right.$ partial pressure of $18 \mathrm{bar}$ ), no increase in $\mathrm{CO}_{2}$ permeability was observed for either membrane, 
indicating excellent resistance to plasticization. Both membranes experienced a gradual decrease in selectivity, suggesting that the dual-mode sorption effect was governed by the Langmuir capacity saturation.

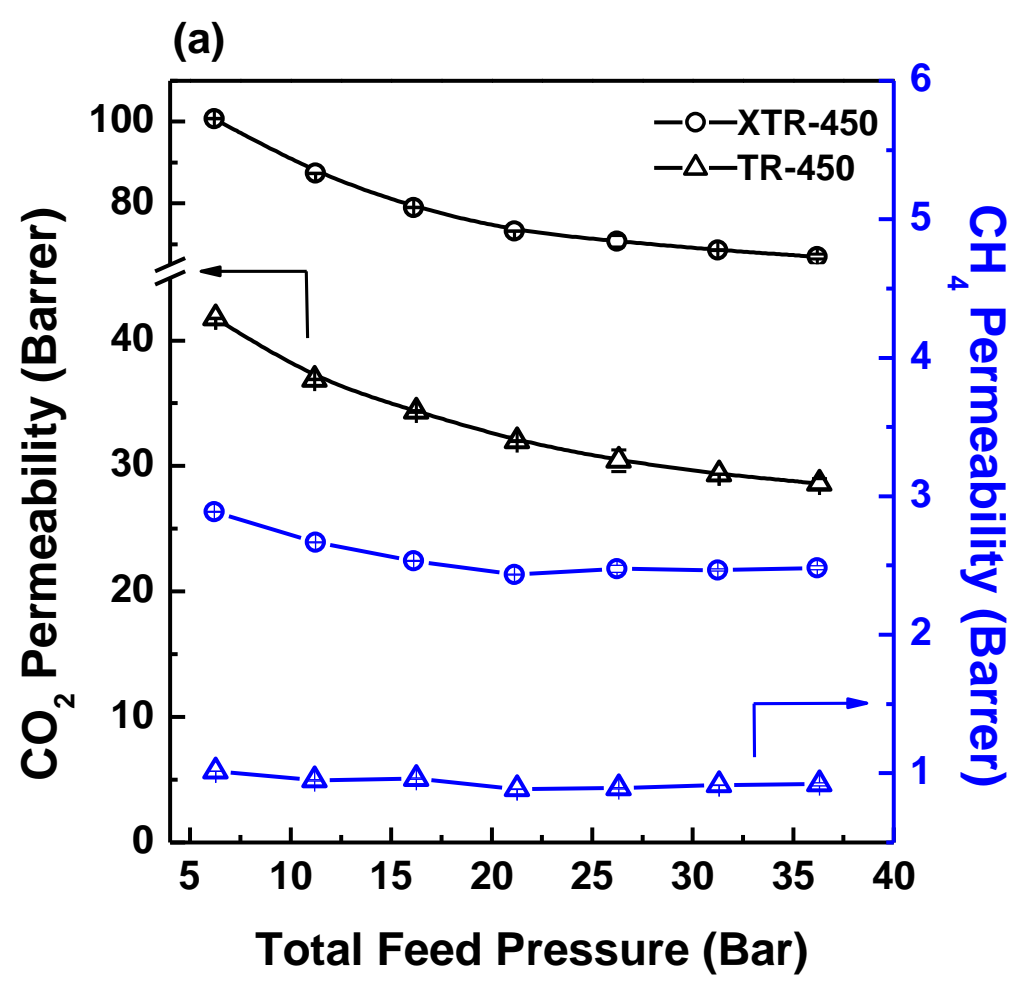




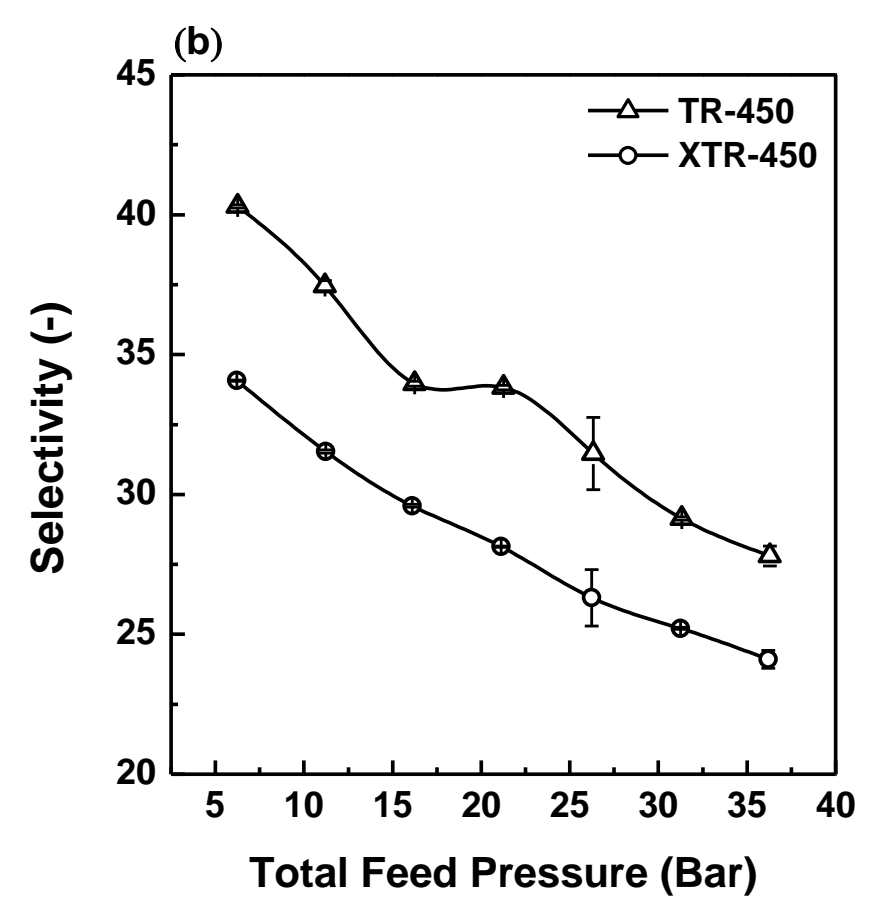

Figure 5-10. Mixed gas permeation results: (a) $\mathrm{CO}_{2}$ permeabilities (black), $\mathrm{CH}_{4}$ (blue) permeabilities and (b) $\mathrm{CO}_{2} / \mathrm{CH}_{4}$ selectivities for XTR-450 (o) and TR-450 ( $\Delta$ ). The $\mathrm{CO}_{2} / \mathrm{CH}_{4}$ (1:1 volume ratio) gas mixture was at $35^{\circ} \mathrm{C}$.

\subsection{Conclusion}

In this study, the influences of thermally induced cross-linking using DABA on the morphological and permeation properties of TR polymers were thoroughly investigated. The results revealed that (i) cross-linking by dianhydride or partial decarboxylation of the carboxylic acid groups of DABA at temperatures below the initial thermal rearrangement and $\mathrm{T}_{\mathrm{g}}\left(350^{\circ} \mathrm{C}\right)$ improved polymer chain rigidity while disrupting polymer chain packing; and (ii) the subsequent thermal rearrangement with cross-linking synergetically increased the polymer chain distance ( $d$-spacing), and with it, the gas diffusivity and permeability. Finally, the XTR- 
PBOI dense films displayed unprecedented $\mathrm{CO}_{2}$ permeabilities, 25-times higher than their precursor membranes, as well as excellent plasticization resistance. It was concluded that the act of disrupting polymer chain packing by cross-linking benefitted the TR polymer and allowed membranes to achieve higher permeabilities during thermal rearrangement since polymer chain rigidity and free volumes were enhanced.

\section{References}

[1] P. Bernardo, E. Drioli, G. Golemme, Membrane gas separation: A review/state of art, Ind. Eng. Chem. Res., 48 (2009) 4638-4663.

[2] G. Maier, Gas separation with polymer membranes, Angewandte Chemie-International Edition, 37 (1998) 2961-2974.

[3] M. Ulbricht, Advanced functional polymer membranes, Polymer, 47 (2006) 2217-2262.

[4] C. Dizman, M.A. Tasdelen, Y. Yagci, Recent advances in the preparation of functionalized polysulfones, Polym. Int., 62 (2013) 991-1007.

[5] N. Du, H.B. Park, M.M. Dal-Cin, M.D. Guiver, Advances in high permeability polymeric membrane materials for CO2 separations, Energy \& Environmental Science, 5 (2012) 73067322.

[6] H.J. Jo, C.Y. Soo, G. Dong, Y.S. Do, H.H. Wang, M.J. Lee, J.R. Quay, M.K. Murphy, Y.M. Lee, Thermally Rearranged Poly(benzoxazole-co-imide) Membranes with Superior Mechanical Strength for Gas Separation Obtained by Tuning Chain Rigidity, Macromolecules, 48 (2015) 2194-2202. 
[7] C.Y. Soo, H.J. Jo, Y.M. Lee, J.R. Quay, M.K. Murphy, Effect of the chemical structure of various diamines on the gas separation of thermally rearranged poly(benzoxazole-co-imide) (TR-PBO-co-I) membranes, Journal of Membrane Science, 444 (2013) 365-377.

[8] M. Calle, Y. Chan, H.J. Jo, Y.M. Lee, The relationship between the chemical structure and thermal conversion temperatures of thermally rearranged (TR) polymers, Polymer, 53 (2012) 2783-2791.

[9] M. Calle, Y.M. Lee, Thermally Rearranged (TR) Poly(ether-benzoxazole) Membranes for Gas Separation, Macromolecules, 44 (2011) 1156-1165.

[10] C.H. Jung, J.E. Lee, S.H. Han, H.B. Park, Y.M. Lee, Highly permeable and selective poly(benzoxazole-co-imide) membranes for gas separation, Journal of Membrane Science, 350 (2010) 301-309.

[11] H.B. Park, S.H. Han, C.H. Jung, Y.M. Lee, A.J. Hill, Thermally rearranged (TR) polymer membranes for CO2 separation, Journal of Membrane Science, 359 (2010) 11-24.

[12] S.H. Han, N. Misdan, S. Kim, C.M. Doherty, A.J. Hill, Y.M. Lee, Thermally Rearranged (TR) Polybenzoxazole: Effects of Diverse Imidization Routes on Physical Properties and Gas Transport Behaviors, Macromolecules, 43 (2010) 7657-7667.

[13] R. Guo, D.F. Sanders, Z.P. Smith, B.D. Freeman, D.R. Paul, J.E. McGrath, Synthesis and characterization of thermally rearranged (TR) polymers: effect of glass transition temperature of aromatic poly(hydroxyimide) precursors on TR process and gas permeation properties, Journal of Materials Chemistry A, 1 (2013) 6063-6072.

[14] R. Guo, D.F. Sanders, Z.P. Smith, B.D. Freeman, D.R. Paul, J.E. McGrath, Synthesis and characterization of Thermally Rearranged (TR) polymers: influence of ortho-positioned 
functional groups of polyimide precursors on TR process and gas transport properties, Journal of Materials Chemistry A, 1 (2013) 262-272.

[15] K. Vanherck, G. Koeckelberghs, I.F.J. Vankelecom, Crosslinking polyimides for membrane applications: A review, Prog. Polym. Sci., 38 (2013) 874-896.

[16] K. Hunger, N. Schmeling, H.B.T. Jeazet, C. Janiak, C. Staudt, K. Kleinermanns, Investigation of cross-linked and additive containing polymer materials for membranes with improved performance in pervaporation and gas separation, Membranes, 2 (2012) 727-763. [17] G. Dong, H. Li, V. Chen, Plasticization mechanisms and effects of thermal annealing of Matrimid hollow fiber membranes for CO2 removal, J. Membr. Sci., 369 (2011) 206-220.

[18] J.D. Wind, C. Staudt-Bickel, D.R. Paul, W.J. Koros, The effects of crosslinking chemistry on $\mathrm{CO} 2$ plasticization of polyimide gas separation membranes, Industrial and Engineering Chemistry Research, 41 (2002) 6139-6148.

[19] J.D. Wind, C. Staudt-Bickel, D.R. Paul, W.J. Koros, Solid-state covalent cross-linking of polyimide membranes for carbon dioxide plasticization reduction, Macromolecules, 36 (2003) 1882-1888.

[20] H. Eguchi, D.J. Kim, W.J. Koros, Chemically cross-linkable polyimide membranes for improved transport plasticization resistance for natural gas separation, Polymer (United Kingdom), 58 (2015) 121-129.

[21] B. Kraftschik, W.J. Koros, Cross-linkable polyimide membranes for improved plasticization resistance and permselectivity in sour gas separations, Macromolecules, 46 (2013) 6908-6921. 
[22] W. Qiu, C.C. Chen, L. Xu, L. Cui, D.R. Paul, W.J. Koros, Sub- T g cross-linking of a polyimide membrane for enhanced CO2 plasticization resistance for natural gas separation, Macromolecules, 44 (2011) 6046-6056.

[23] C.C. Chen, W. Qiu, S.J. Miller, W.J. Koros, Plasticization-resistant hollow fiber membranes for $\mathrm{CO} 2 / \mathrm{CH} 4$ separation based on a thermally crosslinkable polyimide, J. Membr. Sci., 382 (2011) 212-221.

[24] M. Calle, C.M. Doherty, A.J. Hill, Y.M. Lee, Cross-Linked Thermally Rearranged Poly(benzoxazole-co-imide) Membranes for Gas Separation, Macromolecules, 46 (2013) 8179-8189.

[25] M. Calle, H.J. Jo, C.M. Doherty, A.J. Hill, Y.M. Lee, Cross-Linked Thermally Rearranged Poly(benzoxazole-co-imide) Membranes Prepared from ortho-Hydroxycopolyimides Containing Pendant Carboxyl Groups and Gas Separation Properties, Macromolecules, 48 (2015) 2603-2613.

[26] N. Du, M.M. Dal-Cin, G.P. Robertson, M.D. Guiver, Decarboxylation-Induced CrossLinking of Polymers of Intrinsic Microporosity (PIMs) for Membrane Gas Separation†, Macromolecules, 45 (2012) 5134-5139.

[27] W.J. Koros, A.H. Chan, D.R. Paul, Sorption and transport of various gases in polycarbonate, J. Membr. Sci., 2 (1977) 165-190.

[28] H.C. L.R. Smith, T. Saito, L. Smith, Springer handbook of materials measurement methods, Springer, 2006.

[29] J.G. Seong, Y. Zhuang, S. Kim, Y.S. Do, W.H. Lee, M.D. Guiver, Y.M. Lee, Effect of methanol treatment on gas sorption and transport behavior of intrinsically microporous polyimide membranes incorporating Tröger's base, J. Membr. Sci., 480 (2015) 104-114. 
[30] R.M. Barrer, Diffusivities in glassy polymers for the dual mode sorption model, J. Membr. Sci., 18 (1984) 25-35.

[31] Y. Tsujita, Gas sorption and permeation of glassy polymers with microvoids, Prog. Polym. Sci., 28 (2003) 1377-1401.

[32] A.C. Comer, D.S. Kalika, B.W. Rowe, B.D. Freeman, D.R. Paul, Dynamic relaxation characteristics of Matrimid ${ }^{\circledR}$ polyimide, Polymer, 50 (2009) 891-897.

[33] A.C. Comer, C.P. Ribeiro, B.D. Freeman, S. Kalakkunnath, D.S. Kalika, Dynamic relaxation characteristics of thermally rearranged aromatic polyimides, Polymer, 54 (2013) 891-900.

[34] E.M. Maya, A. Tena, J. de Abajo, J.G. de la Campa, A.E. Lozano, Partially pyrolyzed membranes (PPMs) derived from copolyimides having carboxylic acid groups. Preparation and gas transport properties, J. Membr. Sci., 349 (2010) 385-392.

[35] T. Pakula, M. Trznadel, Thermally stimulated shrinkage forces in oriented polymers: 1. Temperature dependence, Polymer, 26 (1985) 1011-1018.

[36] L.M. Robeson, Correlation of separation factor versus permeability for polymeric membranes, Journal of Membrane Science, 62 (1991) 165-185.

[37] L.M. Robeson, The upper bound revisited, Journal of Membrane Science, 320 (2008) 390400.

[38] S. Kim, K.T. Woo, J.M. Lee, J.R. Quay, M. Keith Murphy, Y.M. Lee, Gas sorption, diffusion, and permeation in thermally rearranged poly(benzoxazole-co-imide) membranes, Journal of Membrane Science, 453 (2014) 556-565. 


\section{$\underline{\text { Chapter } 6}$}

\section{Cross-linking Effect on Thermally Rearranged (TR)}

\section{Hollow Fiber Membranes}




\subsection{Introduction}

In previous chapters, comprehensive studies on the dense film preparation using TR polymers were reported to gain in-depth knowledge on the relationship between polymer structure and gas transport properties. In dense films, the inherent gas transport properties were only associated with the chemical structures and free volumes of the polymers. However it should be noted that more than $80 \%$ of the gas separation membrane market are dominated by the hollow fiber membranes with asymmetric structure due to their high packing density and high effective surface area. The fabrication of asymmetric TR membranes in hollow fiber geometry has been studied in our group [1-3]. TR-PBO hollow fiber membranes were prepared using hydroxyl poly(amic acid) (HPAAc) dope solution [1]. The results revealed that the performance of hollow fiber membranes was significantly relied on the dope composition and the spinning conditions. With the optimized spinning conditions, the resultant TR-PBO hollow fiber membranes achieved an impressive $\mathrm{CO}_{2}$ permeance of almost $2500 \mathrm{GPU}$ with $\mathrm{CO}_{2} / \mathrm{N}_{2}$ selectivity around 16. However, scaling-up of TR-PBO hollow fiber membranes remained a major challenge due to (i) the poor chemical stability of the HPAAc dope solution which undergoes degradation in atmosphere; and (ii) poor mechanical properties of the resultant fibers. With this concern, the use of TR-PBOI to fabricate hollow fiber membranes were investigated in our group by Woo et al., in order to overcome the aforementioned issues with TR-PBO and also to facilitate the advantages brought by the azeotropic imidized HPI dope solution [2]. However the studies also revealed that, unlike the TR-PBO hollow fiber membranes prepared by thermal imidization route, the TR-PBOI showed strong densification behavior during the thermal treatment, which compromised the gas transport properties. 
To overcome this undesired densification behavior, here, a new hydroxy copolyimide consists of three diamines: TR-able diamine (HAB), non-TR-able diamine (DAM), and crosslinkable diamine (DABA) was synthesized by using 6FDA as a dianhydride, based on the knowledge from previous chapters which stated that TR-PBOI was mechanical strong enough, and cross-linking from DABA improved not only the permeabilities but also the resistance to shrinkage during thermal treatment. Subsequently, hollow fiber membrane using this material was fabricated and then thermally converted to XTR-PBOI. The $\mathrm{CO}_{2}$ and $\mathrm{N}_{2}$ permeance of a series of XTR-PBOI hollow fiber membranes thermally treated at various temperatures up to $425^{\circ} \mathrm{C}$ were investigated. The main focus of this chapter is to discuss and demonstrate the crosslinking effect on the physical and gas transport properties of the XTR-PBOI hollow fibers fabricated under the optimal spinning condition. Therefore the details of the optimization of hollow fiber fabrication conditions were not reported in this chapter. In addition, the results obtained from uncross-linked TR-PBOI, 6FDA-HAB-DAM were also reported and used for comparisons with the XTR-PBOI hollow fiber membranes.

\subsection{Experimental}

\subsubsection{Materials}

In order to synthesis HPI-DB5, 4,4'-(hexafluoroisopropylidene) diphthalic anhydride (6FDA) purchased from Daikin Industries, Ltd. (Osaka, Japan), 3,3'-dihydroxyl-4,4'-diaminobiphenyl (HAB) was acquired from Wakayama Seika Kogyo Co., Ltd. (Wakayama, Japan), and 2,4,6-trimethyl-m-phylnendiamine (DAM) from Dottikon Exclusive Synthesis AG (Dottikon, Switzerland) and used without further purification. 3,5-diaminobenzoic acid (DABA) were 
purchased from Sigma-Aldrich Co. LLC (St. Louis, USA) and were sublimated before use. Nmethyl-2- pyrrolidone (NMP) and o-xylene were purchased also from Sigma-Aldrich and used without further purification. Ethylene glycol (EG) and propionic acid (PA) which used for preparing hollow fiber membranes were also purchased from Sigma-Aldrich Co. LLC.

\subsubsection{Preparation of dense and hollow fiber membranes}

In this study, a hydroxy copolyimide based on 6FDA and three diamines HAB, DAB, and DABA with a molar ratio of $0.5,0.45$, and 0.05 (labeled as HPI-DB5) was synthesized by azeotropic imidization as described in Chapter $5.5 \mathrm{wt}$ \% polymer solution was prepared using NMP as solvent, and $15 \mu \mathrm{m}$ thick films were obtained by casting on glass plate. $3 \mathrm{~cm} \mathrm{x} 3 \mathrm{~cm}$ dense films were thermally treated at 375,400 for $1 \mathrm{~h}$ and $425^{\circ} \mathrm{C}$ for $30 \mathrm{~min}$, respectively, with a ramping rate of $5{ }^{\circ} \mathrm{C} / \mathrm{min}$ in furnace purged with high purity argon gas after treating at 300 ${ }^{\circ} \mathrm{C}$ for $1 \mathrm{~h}$ to enable cross-linking as shown in Scheme 6-1.

Hollow fiber membranes were prepared using coHPI-DB5 by a dry-jet/wet-quench method using hollow fiber spinning apparatus as shown in Figure 6-1[1, 3]. The dope solution of coHPI-DB5 was prepared using a mixture of NMP and PA (1:1) as solvent and EG as an additive to promote phase separation. The dope solution which consists of polymer, solvent, and additive (25:60:15) was homogenously mixed before extrusion. Prior to extrusion, the dope solution was heated up to $60{ }^{\circ} \mathrm{C}$. Pure water was chosen as the bore solution, and the dope and bore solutions were extruded with a flow rate of $20 \mathrm{ml} / \mathrm{s}$ from the spinneret. The inner diameter of the spinneret was $200 \mu \mathrm{m}$, and the outer diameter $440 \mu \mathrm{m}$. The extruded dope solution was 
coagulated in the coagulation bath filled with water $\left(80^{\circ} \mathrm{C}\right)$ via a $5 \mathrm{~cm}$ air-gap. The nascent hollow fiber membranes were then passed the water godet bath to remove residual solvent, and subsequently collected on a take-up roll. Finally, the hollow fiber membranes were dried in air for several days. Similar spinning protocol was adopted to fabricate HPI-DB5, XHPI-DB5, and XTR-PBOI-DB5 hollow fiber membranes.

\subsubsection{Characterization}

Gel permeation chromatography (GPC, TosohHLC-8320GPC, Seoul, Korea) with a TSKTM Super Multi pore HZ-M column and a refractive index (RI) detector in THF on the basis of standard polystyrenes. Thermo-Gravimetric Analyzer (TGAQ500, TA Instruments) confirmed cross-linking and the formation benzoxazole by thermal rearrangement and analyzed thermal rearrangement temperatures. Isotherm test was also carried out using TGA to study the amount of $\mathrm{CO}_{2}$ emitted during thermal rearrangement. The morphology of the hollow fiber membranes was studied using FE-SEM (JEOL, JSM-6330F, Tokyo, Japan).

\subsubsection{Gas permeation measurements}

Single $\mathrm{CO}_{2}$ and $\mathrm{N}_{2}$ permeabilities of the dense films were measured by time-lag method at $35^{\circ} \mathrm{C}$ with constant downstream volume. The equations below were used to calculate the gas permeability and ideal selectivity. 


$$
\begin{gathered}
\mathrm{P}=\left(\frac{V(S T P) \cdot l}{\Delta p \cdot A \cdot T}\right) \frac{d p}{d t} \\
\alpha=\frac{\mathrm{P}_{1}}{\mathrm{P}_{2}}
\end{gathered}
$$

where $\mathrm{P}(\mathrm{cmHg})$ is the gas permeability, $\mathrm{V}(\mathrm{cm} 3)$ is the volume rate, $l(\mathrm{~cm})$ is the membrane thickness, $\mathrm{A}\left(\mathrm{cm}^{2}\right)$ is the effective area of membrane, and $\mathrm{T}(\mathrm{K})$ is the temperature. The unit of permeability is Barrer and it is based on the standard temperature and pressure (STP) condition (1 Barrer $\left.=10^{-10} \mathrm{~cm}^{3}(\mathrm{STP}) \cdot \mathrm{cm} / \mathrm{cm}^{2} \cdot \mathrm{s} \cdot \mathrm{cmHg}\right)$, denotes ideal selectivity which is the ratio of pure gas permeabilities of gas 1 over gas 2 .

TR-PBO hollow fiber membrane modules were fabricated, and the pure gas permeation tests were performed using $\mathrm{N}_{2}(3.64 \AA)$ and $\mathrm{CO}_{2}$ (3.3 $\AA$ ). A shell side feed configuration was adopted for all the permeation experiments, with the feed pressure increasing from 1 to 6 bar (1 bar increment) at $25^{\circ} \mathrm{C}$. The gas permeance $(\mathrm{P} / \mathrm{l})$ was calculated based on the following equation

$$
\frac{P}{l}=\frac{Q}{\Delta p A}
$$

where $\mathrm{Q}, \Delta \mathrm{p}$, and A are the volumetric gas flow rate $\left(\mathrm{cm}^{3}(\mathrm{STP}) / \mathrm{s}\right)$, the pressure difference between the feed and permeation side (cmHg), and the membrane effective area $\left(\mathrm{cm}^{2}\right)$, respectively. The unit of gas permeance (P/l) is GPU (gas permeation unit), defined as 1 GPU $=1 \times 10^{-6} \mathrm{~cm}^{3}(\mathrm{STP}) / \mathrm{cm}^{2} \mathrm{~s} \mathrm{cmHg}$. The membrane ideal selectivity is defined as the ratio of the permeances of different gas species 


$$
\begin{gathered}
\alpha=\frac{\mathrm{P}_{1}}{\mathrm{P}_{2}}=\frac{\mathrm{P}_{1} / l}{\mathrm{P}_{2} / l} \\
l_{\text {skin }}=\frac{\text { Permeability }(\text { dense })}{\text { Permeance }(\text { Hollow } \text { fiber })}=\frac{P}{P / l_{\text {skin }}}
\end{gathered}
$$
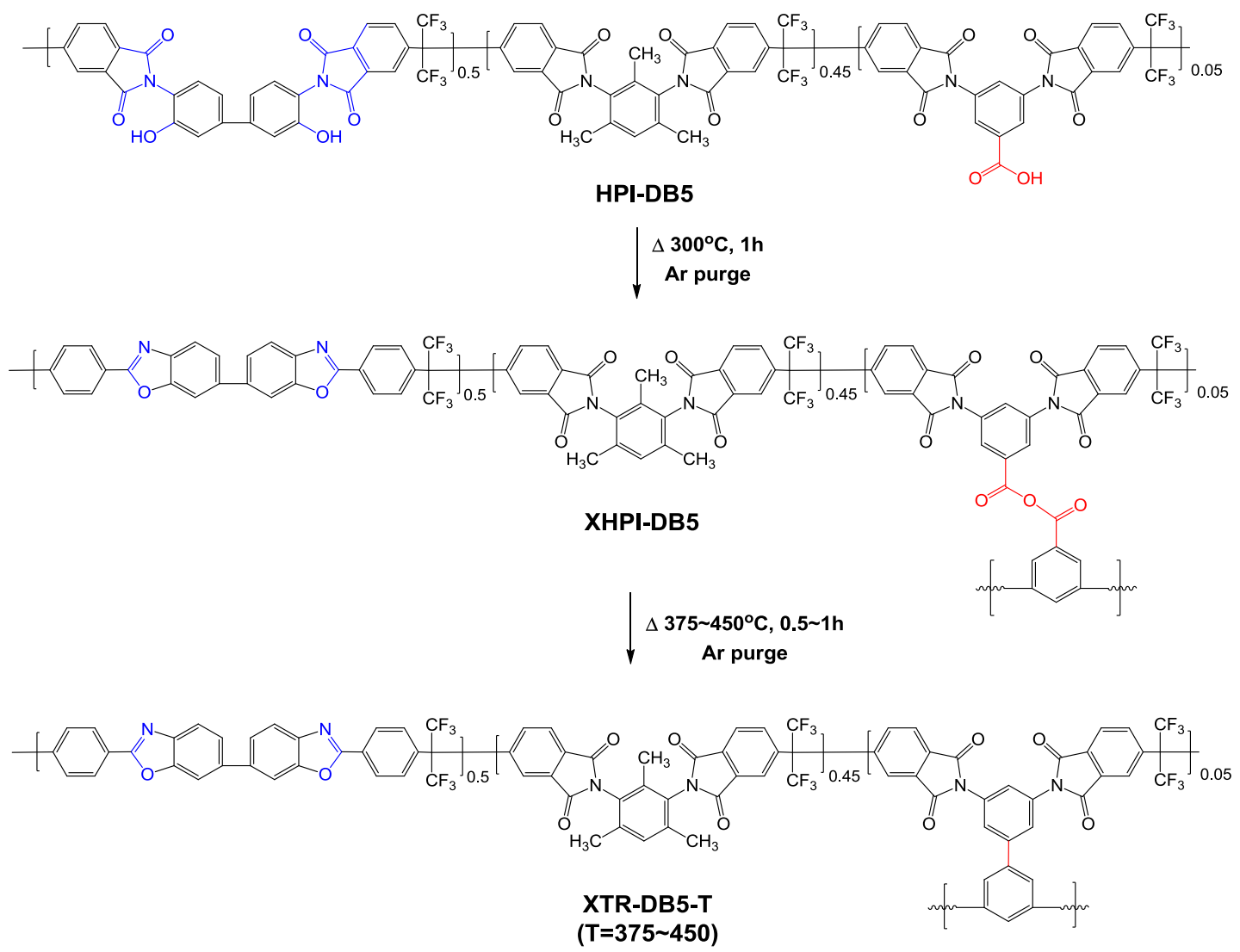

Scheme 6-1 Proposed reaction pathway and chemical structures of 5\% DABA and 45\% DAM contained cross-linked thermally rearranged poly(benzoxazole-co-imide) membrane (XTRPBOI-DB5) derived from hydroxy copolyimide (HPI-DB5) 


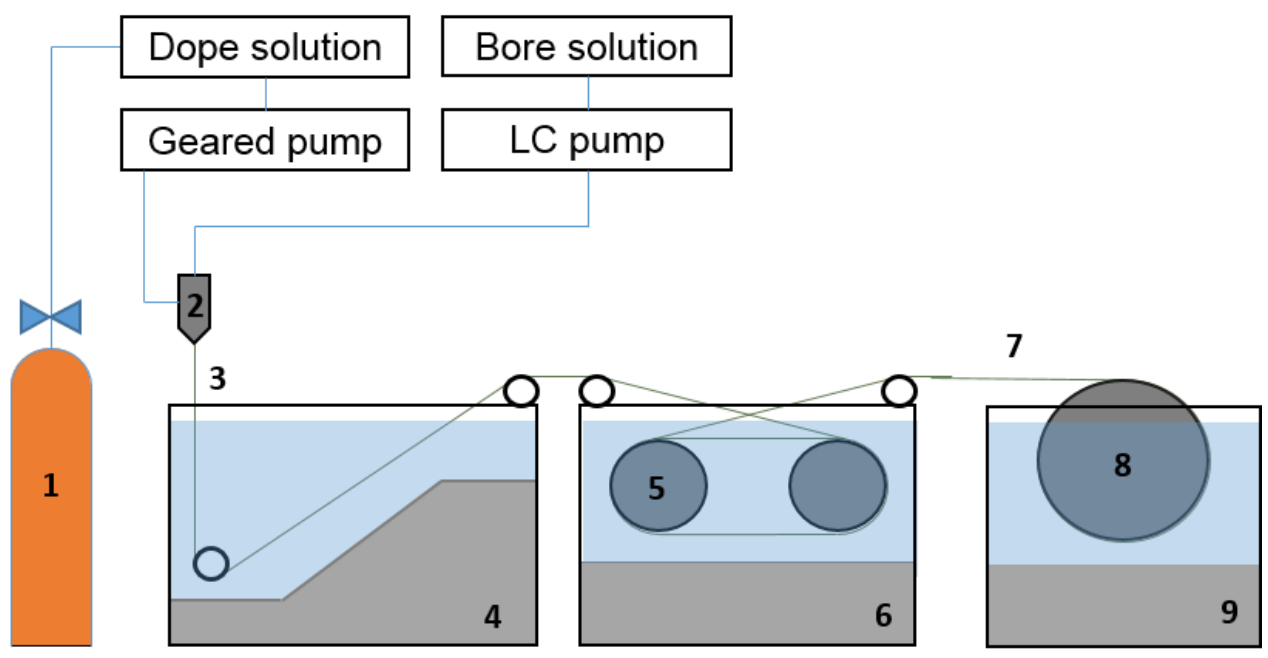

Figure 6-1 Experimental set-up for hollow fiber spinning (1: nitrogen gas tank, 2: spinneret, 3: air gap, 4: coagulation bath, 5: fiber guiding wheel, 6: godet bath, 7: hollow fiber membrane, 8:take-up roll, 9: take-up bath)

\subsection{Results and Discussions}

\subsubsection{Preparation of polymer and dense membranes}

In this study, the 5 mol\% contained hydroxy copolyimides based on 6FDA-HAB-DAM (HAB/ DAM/ DABA: 50/ 45/ 5) was synthesized via azeotropic imidization and designated as HPI-DB5. 6FDA-HAB/DAM/DABA was chosen because 6FDA-HAB-DAM in main backbone showed high mechanical strength and gas permeability after thermal rearrangement (Chapter 3) and DABA functioned as cross-linker during thermal treatment (Chapter 5). The weight average molecular weight of polymer was 125,000 g/mol and poly-dispersity index (PDI) was 2.7. The intrinsic viscosity was $0.9 \mathrm{dg} / \mathrm{L}$. The synthesized HPI-DB5 was dissolved in NMP (5 wt\%) and casted on the glass plate and $50 \mu \mathrm{m}$ thick dense films were prepared.

Prior to the thermally rearrangement using HPI-DB5, the thermal behavior of HPI-DB5 
using TGA was investigated as shown in Figure 6-2. HPI-DB5 membrane showed the weight loss around $300{ }^{\circ} \mathrm{C}$ indicating the removals of residual solvent and anhydride cross-linking in DABA moiety. All samples were treated at $300{ }^{\circ} \mathrm{C}$ for $1 \mathrm{~h}$ to enable the cross-linking (the crosslinked membranes were labeled as XHPI-DB5). The TGA results of XHPI-DB5 membrane reflected the completely removal of the residual solvent and the formation of cross-linking of DABA and clearly showed two major weight losses by thermal rearrangement from $350^{\circ} \mathrm{C}$ and carbonization from $480{ }^{\circ} \mathrm{C}$ respectively. XTR-DB5-350 showed a major $\mathrm{CO}_{2}$ emission in the thermal rearmament region indicating a slight percentage of conversion; whereas XTR-DB5400 showed only slightly decrease in weight loss which indicated a high conversion percentage. The XTR-DB5-425 showed only carbonization region indicated the membrane was highly converted and cross-linked.

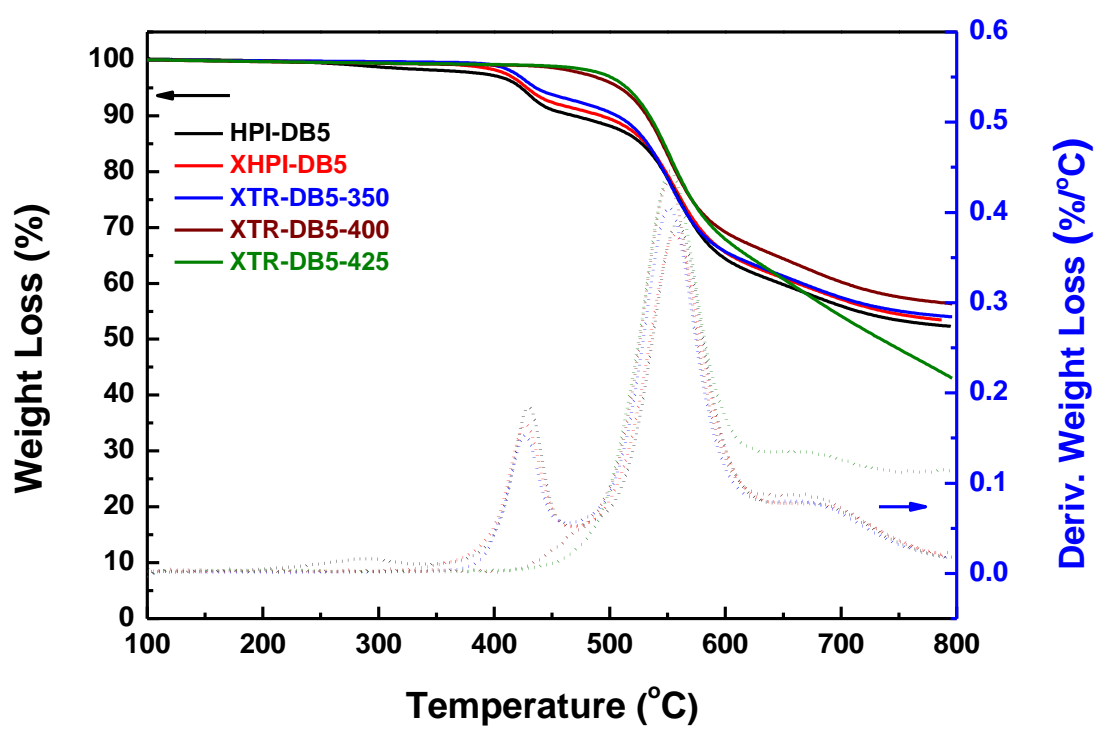

Figure 6-2 Weight loss and derivative weight loss comparisons of each XTR-PBOI dense membranes measured by TGA while heating up to $800 \mathrm{oC}(5 \mathrm{oC} / \mathrm{min})$ purged with nitrogen. 
Mechanical properties of XTR-DB5 membranes were measured by UTM. The averages of tensile strength and elongation at break of each films were summarized in Table 6-1. The tensile strength and elongation at break of XTR-DB5s decreased as increasing in the treatment temperatures. The almost completely thermally rearranged XTR-DB5-425 results in 13\% loss of tensile strength and 38\% loss of elongation at break as comparing with XHPI-DB5. It is noticeable that XTR-DB5-400 and 425 showed much higher tensile strength more than $95 \mathrm{MPa}$ and $20 \%$ of elongation at break than TR-PBOI membrane, HAB5-DAM5, which obtained 15\% of elongation at break and $80 \mathrm{MPa}$ of tensile strength (noted that it was treated at $400{ }^{\circ} \mathrm{C}$ for 2 h) in previous study [4].

Table 6-1 Summary of the mechanical properties of XTR-PBOIs

\begin{tabular}{|c|c|c|}
\hline & \multicolumn{2}{|c|}{ Mechanical properties } \\
\hline & Tensile Strength (MPa) & Elongation at break (\%) \\
\hline XHPI-DB5 & 109 & 32 \\
\hline XTR-DB5-375 & 102 & 30 \\
\hline XTR-DB5-400 & 97 & 25 \\
\hline XTR-DB5-425 & 95 & 20 \\
\hline
\end{tabular}

\subsubsection{Preparation of hollow fiber membranes, gas permeation and effect of cross- linking on hollow fiber membrane}

The fabricated asymmetric hollow fiber membranes were thermally treated using the same conditions as in dense membranes. The morphology of XHPI-DB5 and XTR-DB5-425 hollow fiber membranes were representatively shown in Figure 6-3. Using the optimized spinning condition, sponge-like hollow fiber membranes were fabricated without any finger-like micro- 
voids in support layer.

Pure gas transport properties of $\mathrm{CO}_{2}$ and $\mathrm{N}_{2}$ were investigated to demonstrate the feasibility of using such membranes for post-combustion $\mathrm{CO}_{2}$ capture process. The results of $\mathrm{CO}_{2}$ permeance and $\mathrm{CO}_{2} / \mathrm{N}_{2}$ selectivities results are summarized in Table 6-1 along with the $\mathrm{CO}_{2}$ permeabilities and selectivities measured using dense membranes for comparison. For the dense membranes, $\mathrm{CO}_{2}$ permeability of XHPI-DB5 was obtained only 92 Barrer with $\mathrm{CO}_{2} / \mathrm{N}_{2}$ selectivity of 24.4. As increasing in treatment temperatures, the $\mathrm{CO}_{2}$ permeability increased gradually and selectivity slightly dropped which was well corresponded with the typical behavior of TR membranes by enlarging free volumes at higher thermal treatment temperatures. Finally, the XTR-DB5-425 membrane obtained 785 Barrer and 19.8 of $\mathrm{CO}_{2} / \mathrm{N}_{2}$. As comparing with uncross-linked TR-PBOI membranes based on 6FDA-HAB-DAM, the permeabilities and selectivities were shown similar or slightly higher values due to the small portion of DABA.

$\mathrm{CO}_{2}$ permeance of hollow fiber also increased as increasing in treatment temperatures. Absolute gas permeance results of TR and XTR hollow fiber membranes were not comparable because the performances were significantly dependent on the dope compositions and the spinning conditions. However, skin layer variation was compared to indicate the effect of crosslinking as shown Figure 6-4 and Table 6-2. The effective skin layer was calculated using the Equation (6-4) based on $\mathrm{CO}_{2}$ permeability and permeance. The calculated thickness of effective skin layer of XTR-PBOI membrane sustained around $0.27 \sim 0.38 \mathrm{~nm}$ up to $425{ }^{\circ} \mathrm{C}$ and $\mathrm{CO}_{2}$ permeance kept increasing as increasing in treatment temperature. On the other hand, the uncross-liked TR-PBOI membrane showed substantial drops of $\mathrm{CO}_{2}$ permeance at temperatures higher than $375^{\circ} \mathrm{C}$. This drop of permeance was attributed to the densification of polymer chain 
matrix by passing chain relaxation temperatures and glass transition temperature around 383 ${ }^{\circ} \mathrm{C}[2,4]$. Unlike the permeability increment of dense membranes by thermal rearrangement after $400{ }^{\circ} \mathrm{C}$, the densified skin layer of hollow fiber membranes, consequently, caused in the loss of gas permeance. On the other hand, XTR-PBOI hollow fiber membrane showed continuous increment of gas permeance even higher than $400{ }^{\circ} \mathrm{C}$. It was postulated that the cross-linking suppressed the polymer chain relaxation and prevented the polymer matrix from collapsing and thus, limiting the degree of densification of skin layer. It was also found that the cross-linked structure also sustained the polymer matrix in all layers (skin, transition, and support layer) and avoided the undesired densification. As a result, a $\mathrm{CO}_{2}$ permeance of over 1000 GPU was achieved. This effect of cross-linking was in good agreement with the result of tPBO hollow fibers which showed high permeance at high temperatures.

The densification that TR-PBOI hollow fibers experience when passing $\mathrm{T}_{\mathrm{g}}$ presented a major challenge for the TR membranes for industrial scale implementation. The results presented here clearly indicated that the cross-linking of TR-PBOI using only a small portion of DABA was the solution to overcome this issue by suppressing densification, and therefore resulted in an increased $\mathrm{CO}_{2}$ permeance up to $1000 \mathrm{GPU}$ with $\mathrm{CO}_{2} / \mathrm{N}_{2}$ selectivity 21 . 

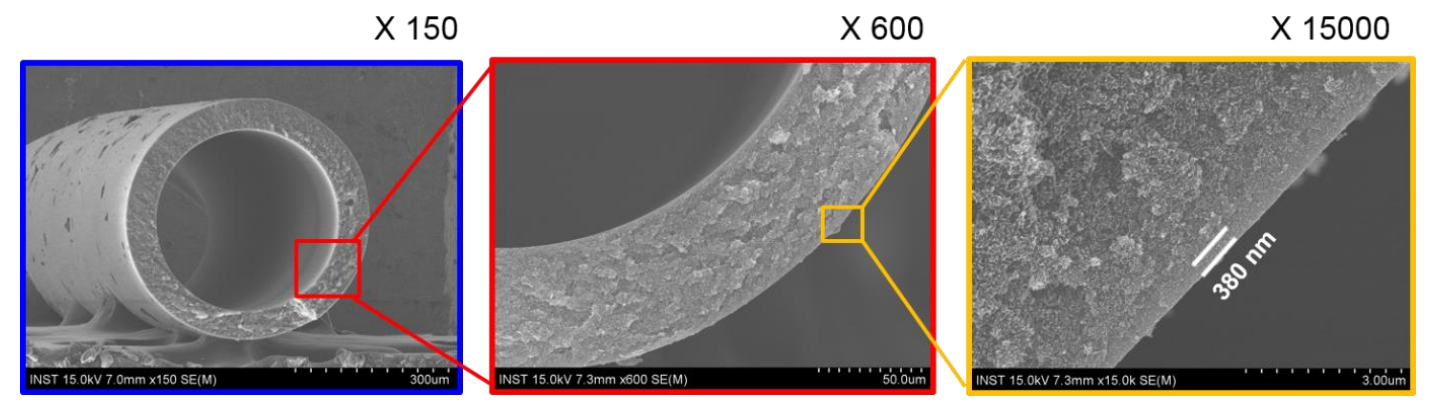

(a) XHPI-DB5

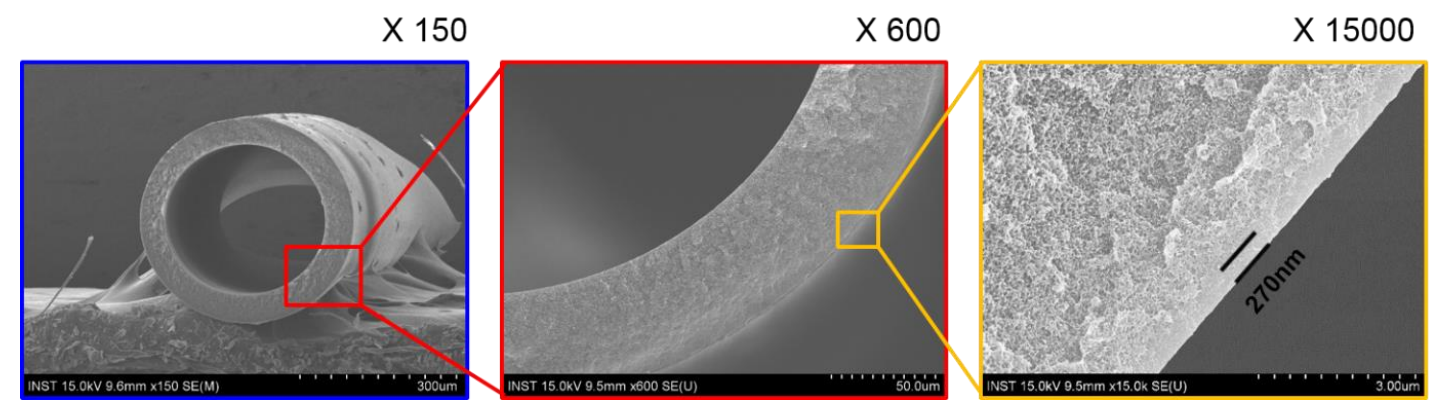

(b) XTR-DB5-425

Figure 6-3 Scanning electron microscopy (SEM) images of the asymmetric hollow fiber membrane of (a) XHPI-DB5 and (b) XTR-DB5-425: entire cross-section (magnification 150x) (right), fiber wall cross-section (600x) (center), and top layer (15,000x) (left) 
Table 6-2 Pure $\mathrm{CO}_{2}$ and $\mathrm{N}_{2}$ permeance and selectivities of XHPI and XTR-PBOI hollow fiber membranes, apparent thickness of effective skin layer of each fiber, comparing with TR-PBOI hollow fiber performances.

\begin{tabular}{|c|c|c|c|c|c|c|c|}
\hline \multirow{2}{*}{$\begin{array}{l}\text { Cross-linked } \\
\text { TR-PBO } \\
\text { Membrane }\end{array}$} & \multicolumn{3}{|c|}{$\begin{array}{l}\text { Gas transport properties in dense } \\
\text { membranes }\end{array}$} & \multicolumn{3}{|c|}{$\begin{array}{l}\text { Gas transport properties in } \\
\text { hollow fiber membranes }\end{array}$} & \multirow{2}{*}{$\begin{array}{l}\text { Calculated } \\
\text { Effective } \\
\text { Skin Layer } \\
\text { (nm) }\end{array}$} \\
\hline & $\begin{array}{c}\mathrm{P}_{\mathrm{CO} 2} \\
\text { (Barrer) }\end{array}$ & $\begin{array}{c}\mathrm{P}_{\mathrm{N} 2} \\
\text { (Barrer) }\end{array}$ & $\mathrm{CO}_{2} / \mathrm{N}_{2}$ & $\begin{array}{l}\mathrm{P}_{\mathrm{CO} 2} \\
(\mathrm{GPU})\end{array}$ & $\begin{array}{c}\mathrm{P}_{\mathrm{N} 2} \\
(\mathrm{GPU})\end{array}$ & $\mathrm{CO}_{2} / \mathrm{N}_{2}$ & \\
\hline \multicolumn{8}{|c|}{$\begin{array}{c}\text { XTR-PBOI membranes } \\
\text { (6FDA-HAB50/DAM45/DABA5) }\end{array}$} \\
\hline XHPI-DB5 & 92 & 3.8 & 24.3 & 245 & 13.8 & 17.8 & 0.38 \\
\hline XTR-DB5-375 & 105 & 4.3 & 24.6 & 341 & 17.7 & 19.2 & 0.31 \\
\hline XTR-DB5-400 & 210 & 10.1 & 20.8 & 624 & 28.6 & 21.9 & 0.34 \\
\hline XTR-DB5-425 & 270 & 13.6 & 19.9 & 1001 & 48.4 & 20.7 & 0.27 \\
\hline \multicolumn{8}{|c|}{$\begin{array}{c}\text { TR-PBOI membrane } \\
\text { (6FDA-HAB50/DAM50) [2] }\end{array}$} \\
\hline HPI & 26 & 0.5 & 52.0 & 120 & 4.2 & 28.9 & 0.22 \\
\hline TR-375 & 105 & 4.6 & 22.7 & 560 & 33.3 & 16.8 & 0.19 \\
\hline TR-400 & 196 & 9.4 & 20.9 & 253 & 12.9 & 19.6 & 0.77 \\
\hline TR-450 & 747 & 37.1 & 20.1 & 97 & 3.5 & 27.7 & 7.70 \\
\hline
\end{tabular}



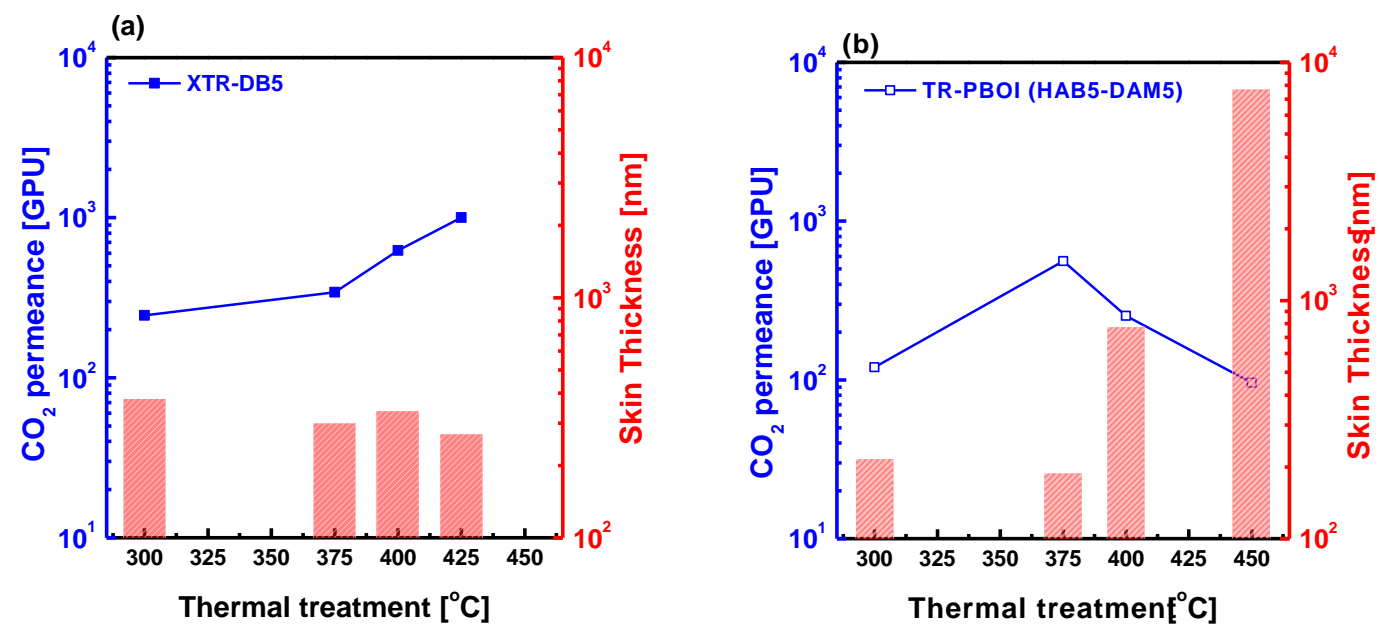

Figure 6-4 Profiles of $\mathrm{CO}_{2}$ permeance and skin thickness of hollow fiber as a function of increased thermal rearrangement temperatures, (a) XTR-PBOIs, (b) TR-PBOI.

\subsection{Conclusion}

XTR-PBOI hollow fiber membranes were prepared using 6FDA-HAB/DAM/DABA (50/45/5) polymer containing 5\% DABA, synthesized by azeotropic imidization route to understand the cross-linking effect on hollow fiber membranes. Gas transport properties of the un-cross-linked TR-PBOI, 6FDA-HAB/DAM (50/50), were also prepared to compare with the XTR-PBOI membranes. The XTR-PBOI dense membrane only containing 5\% DABA showed slight increase in gas permeability when comparing with the un-cross-linked TR-PBOI membranes. However, the $\mathrm{CO}_{2}$ permeance of XTR-PBOI hollow fiber membrane experienced significant increase as increasing in temperatures which was mainly owing to the cross-linking effect which preserved the micro-cavity structure of the polymer matrix, while the $\mathrm{CO}_{2}$ permeance of TR-PBOIs dropped when passing the glass transition and relaxation temperatures. 
In conclusion, cross-linking showed positive effects on restricting the polymer matrix from collapsing, and therefore sustained the polymer matrix and micro-cavity structure, and consequently, suppressing the undesired densification of skin layer to prevent the permeance drop.

\section{References}

[1] S. Kim, S.H. Han, Y.M. Lee, Thermally rearranged (TR) polybenzoxazole hollow fiber membranes for $\mathrm{CO}_{2}$ capture, Journal of Membrane Science, 403-404 (2012) 169-178.

[2] K.T. Woo, J. Lee, G. Dong, J.S. Kim, Y.S. Do, H.J. Jo, Y.M. Lee, Thermally rearranged poly(benzoxazole-co-imide) hollow fiber membranes for $\mathrm{CO}_{2}$ capture, Journal of Membrane Science, Revision (2016).

[3] K.T. Woo, J. Lee, G. Dong, J.S. Kim, Y.S. Do, W.S. Hung, K.R. Lee, G. Barbieri, E. Drioli, Y.M. Lee, Fabrication of thermally rearranged (TR) polybenzoxazole hollow fiber membranes with superior $\mathrm{CO}_{2} / / \mathrm{N}_{2}$ separation performance, Journal of Membrane Science, 490 (2015) 129138.

[4] H.J. Jo, C.Y. Soo, G. Dong, Y.S. Do, H.H. Wang, M.J. Lee, J.R. Quay, M.K. Murphy, Y.M. Lee, Thermally Rearranged Poly(benzoxazole-co-imide) Membranes with Superior Mechanical Strength for Gas Separation Obtained by Tuning Chain Rigidity, Macromolecules, 48 (2015) 2194-2202. 


\section{$\underline{\text { Chapter } 7}$}

\section{Conclusion and Directions for Future Studies}




\subsection{Conclusions and Future Studies}

In this final chapter, the main conclusions of each study carried out and the proposal of further studies regarding thermally rearranged polymers for practical gas separation applications derived from the use of well-designed modifications of the chemical structure of polymers are proposed.

In Chapter 1, recently developed polymer membranes in gas separation were introduced as an obligation of making changes in the accepted trends of gas separation technologies owing to the duty of reducing and sequestrating $\mathrm{CO}_{2}$, which is the main greenhouse gas that produces global warming. Various high performance polymer membranes such as Polymers of Intrinsic Microporosity (PIMs), Carbon Molecular Sieves (CMSs), novel aromatic polyimides (PIs) and Thermally Rearranged Polybenzoxazoles (TR-PBOs) were chosen as the representative examples of novel polymer membrane materials and their high permeabilities were attributed to the existence of a rigid polymer backbone. Thermally Rearranged (TR) polymers, developed in the last decade, have been developed and their properties have been tuned by changing their chemical structures as well as exploring the search of relationships between the gas separation properties and the mechanical properties as a function of the thermal treatment conditions. It has been clearly stated that the fragility, low mechanical properties, inherent to TR membranes is an issue to be solved in order to implement these materials in real-world applications. Also, the rational modification of the precursor chemical structure on thermal rearrangement to achieve very high productivity materials is necessary for the implementation of TR polymers in industrial applications.

In Chapter 2, the study of the main characteristics of polymers as a function of their thermal 210 
treatments and also as a function of the chemical structure of precursors of TR-PBO and poly(TR-polybenzoxazole-co-imide) (TR-PBOI) has permitted to find a linear relationship between the gas separation properties and the value of the glass transition temperature $\left(T_{g}\right)$ and the thermal rearrangement temperature applied to the polymer (TTRs). It has been determined the importance of understanding $\mathrm{T}_{\mathrm{g}}$ and TTRs for each TR polymers before thermal rearrangement due to its different thermal behavior, which is depending on the chemical structure. Moreover, this assumption has been able to suggest that if the hydroxy polyimide precursor haves a lower $\mathrm{T}_{\mathrm{g}}$, the employed thermal rearrangement temperature can be reduced. This fact could decrease the cost of making TR materials.

In Chapter 3, the existence of new relationships between chemical structures of precursors and the gas transport properties of final TR-PBO and TR-PBOIs were introduced. Here, in order to obtain materials easy to be employed in industrial applications, the use of copolymerization with polyimide derived from non-TR able part (common aromatic diamines) was strongly suggested to solve the fragility of TR-PBO. This approach has been able to produce TR materials having mechanical properties with more than $15 \%$ elongation at break and with 80MPa of tensile strength. In particular, the use of rigid non-TR-able diamine such as 2,4,6-trimethyl-MPD (DAM) improved the gas permeability while flexible non-TR-able diamine such as oxy-dianiline (ODA) decrease the gas productivity. In addition, it has been obtained a relationship from the ratio of non-TR-able diamines and TR-able ones, what can tune the gas permeabilities of TR materials by controlling the diamine compositions and hence the final macromolecular structure. TR-PBOIs have been proposed as good candidate s for the implementation in gas separation applications and the obtained results data have served as a 
guideline for optimization of polymer composition.

In Chapter 4, the use of spirobisindane moieties have been introduced into TR polymer backbones. By using this approach, the mechanical properties of spiroTR-PBOs were strongly enhanced. Moreover, the gas permeabilities were highly enhanced by the losing chain packing introduced by the ladder-like structure of the spirobisindane groups along with the presence of rigid benzoxazole groups. SpiroTR-PBOs have been demonstrated as excellent candidates to apply in practical gas separation processes. However, the complicated synthetic route and the low yield of spiro-monomer obtained during its synthesis should be clearly improved in order to apply these materials in industrial gas separation applications.

In Chapter 5, a fundamental study of cross-linked thermally rearranged polymers was carried out, and the results have permitted to establish that there is dependence between the final properties and the amount of cross-linking introduced by the carboxylic acid groups of DABA. As a main conclusion, loss of the carboxylic moieties induced cross-linking from DABA moieties by formation of a pillar-like structure which is able to sustain the free volume elements among the polymer chains and also by increasing rigidity of the polymer backbones. This fact became much effective during thermal rearrangement, and consequently, it was observed an improving of 25 times in the permeability values, which is 4 -folded higher than the observed values for uncross-linked TR-PBO membranes.

In Chapter 6, it was observed that cross-linking also influences the formation of hollow fiber membranes which showed additional densification by treating at high temperature. Definitely, the resistance to the formation of shrinkage (inherent to the formation of TR 
materials due to the loss of mass in the thermal treatment) by cross-linking could provide materials with economic advantages. As one of the good candidate for implementation to gas separation area, crosslinked poly(benzozaxole-co-imide) (XTR-PBOIs) requires additional research, for instance, to determine the effect of film thickness and heating rate in dense film form. Also, sub- $T_{g}$ cross-linked TR polymers were only studied in this research, and hence the use of temperatures above $T_{g}$ or the search of relationship between gas separation properties with $T_{g}$ should be more precisely defined with the aim of improving the final properties of membranes. As a next step, hollow fiber membranes are going to be thoroughly studied to understand the effect of cross-linking on these fibers and also to figure out the final gas performances in real-world operations. 


\section{List of Publications}

1. Calle, M., Jo, H. J., Doherty, C. M., Hill, A. J. , and Lee, Y. M. (2015) Cross-linked Theramlly Rearranged Poly(benzoxzaole-co-imide) Membranes Prepared from ortho-Hydroxycopolyimides Containing Pendant Carboxyl Groups and Gas Separation Properties. Macromolecules, 48: p.2603-2613

2. Jo, H. J. Soo, C. Y., Dong, G., Do, Y. S., Wang, H., H., Lee, M., J., Quay, J. R., Murphy, M. K., Lee, Y. M. (2015) Thermally Rearranged Poly(benzoxazole-coimide) Membranes with Superior Mechanical Strength for Gas Separation Obtained by Tunigy Chain Rigidity. Macromolecules, 48 p.2194-2202

3. Zhuang, Y., Seoung, J. G., Do, Y. S., Jo, H. J., Lee, M. J., Lee, Wang, G., Lee, Y. M. and Guiver, M. D., (2014) Effect of Isomerism on Molecular Packing and Gas Transport Properties of Poly(benzoxazole-co-imide)s. Macromolecules, 47 (22): p. 7947-7957

4. Zhuang, Y., Seoung, J. G., Do, Y. S., Jo, H. J., Cui, Z., Lee, J., Lee, Y. M. and Guiver, M. D., (2014) Intrinsically Microporous Soluble Polyimides Incorporating Tronger's base for Membrane Gas Separation . Macromolecules, 47: p. 3254-3562.

5. Comesaña-Gandara, B., Calle, M., Jo, H. J., Hernandez, A., Campa, J., Abajo, J., Lozano, A., E., and Lee, Y. M., (2014): Thermally rearrange polybenzoxazole membranes with biphenyl moieties: Monomer isomeric effect. Journal of Membrane Science, 450: p. 369-379.

6. Soo, C.Y., Jo, H. J., Lee, Y. M., Quay, J. R., and Murphy, M. K., (2013): Effect of chemical structure of various diamines on the gas separation of thermally rearranged poly(benzoxazole-co-imide) (TR-PBO-co-I) membranes, Journal of Membrane Science, 444: p. 365-377.

7. Kim, S., Jo, H. J., and Lee, Y. M., (2013): Sorption and transport of small gas molecules in thermally rearranged (TR) polybenzoxazole membranes based on 2,2bis(3-amino-4-hydroxyphenyl)-hexafluoropropane (bisAPAF) and 4,4'hexafluoroisoprophylidene diphatalic anhydride (6FDA). Journal of Membrane Science, 441: p. 1-8.

8. Li, S. ${ }^{1}$, Jo, H. J. ${ }^{1}$, Han, S. H., Park, C. H., Kim, S., Budd, P. M., and Lee, Y. M., (2013): Mechanically robust thermally rearranged (TR) polymer membranes with spirobisindane for gas separation. Journal of Membrane Science, 434: p. 137-147. ( ${ }^{1}$ : equal contribution) 
9. Han, S. H., Doherty, C. M., Marmiroli, B., Jo, H. J., Buso, D., Patelli, A., Schiavuta, P., Innocenzi, P., Lee, Y. M., Thronton, A. W., Hill, A. J., and Falcaro, P., (2013): Simultaneous Microfabrication and Tuning of the Permselective Properties in Microporous Polymers Using C-ray Lithography. Small, 9(13): p. 2277-2282.

10. Calle, M., Chan, Y., Jo, H. J., and Lee, Y. M., (2012): The relationship between the chemical strucure and thermal conversion temperature of thermally rearranged (TR) polymers. Polymer, 53: p. 2783-2791. 
